
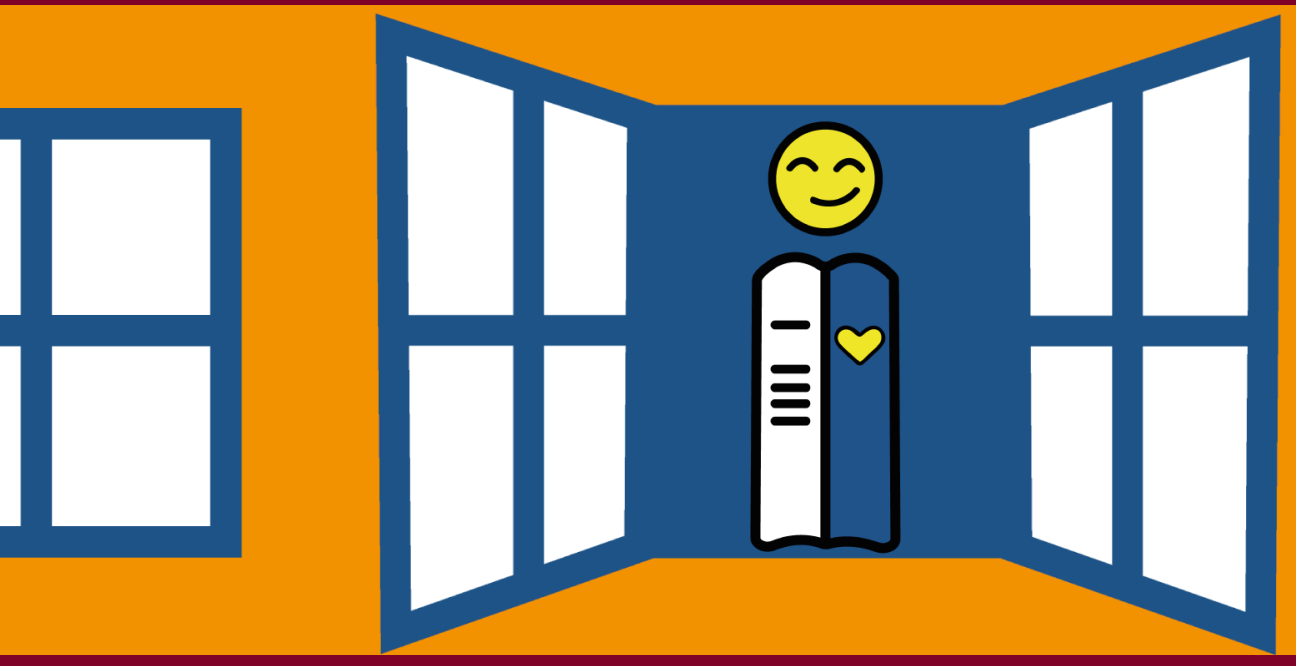

FOGYATÉKOSSÁG ÉS TÁRSADALOM

ELTE BÁRCZI GUSZTÁV GYÓGYPEDAGóGIAI KAR 


\section{FOGYATÉKOSSÁG ÉS TÁRSADALOM}

$2021 / 1$

Alapítók: ELTE Bárczi Gusztáv Gyógypedagógiai Kar • ELTE Eötvös Kiadó Kft • Fogyatékosságügyi Tudásbázis Alapítvány

A FOGYATÉKOSSÁG ÉS TÁRSADALOM évente kétszer megjelenő szakmai, tudományos perodika. Magyar nyelven megjelent, kutatási eredményeket bemutató cikkeinek más, idegen nyelven történő későbbi publikálásához - az első publikálás helyének jelzésével - hozzájárul. Elsődleges nyelve a magyar, de egyes cikkeit alkalmanként angol vagy német nyelven is elfogadja, közli.

A közlésre szánt kéziratokat a következő címen fogadjuk: ftszerkesztobizottsag@gmail.com

Meg nem rendelt kéziratokat és egyéb küldeményeket nem őrzünk meg és nem küldünk vissza.

AZ EGYENLŐ ESÉLYÜ HOZZÁFÉRÉS ELŐSEGÍTÉSE ÉRDEKÉBEN PERIODIKÁNKBAN NEM HASZNÁLUNK LÁBJEGYZETEKET, ILLETVE VÉGJEGYZETEKET.

Minden jog fenntartva.

\section{Föszerkesztő:}

Hoffmann István

Alapító föszerkesztő:

Könczei György

Szakmai szerkesztő:

Horváth Péter László

Szerkesztőbizottság:

Cserti-Szauer Csilla

Hernádi llona

Horváth Péter László

Katona Vanda

Kunt Zsuzsanna

Maléth Anett

Sándor Anikó

Zászkaliczky Péter

Szöveggondozás: Borsos-Szabó Ágnes Layout: Durmits Ildikó

\section{Kiadó:}

Eötvös Loránd Tudományegyetem Bárczi Gusztáv Gyógypedagógiai Kar

A kiadásért felel:

az ELTE Bárczi Gusztáv

Gyógypedagógiai Kar dékánja

\section{Szerkesztőség:}

1097 Budapest, Ecseri út. 3.

Telefon: +3613585537

HU ISSN 2060-8292

DOI 10.31287/FT.hu.2021.1 


\section{TARTALOM}

\section{FOGYATÉKOSSÁG ÉS TÁRSADALOM}

\section{$2021 / 1$}

DR. HORVÁTH PÉTER LÁSZLÓ

Szerkesztői előszó

CZIRÁKI ZSOLT - DR. HORVÁTH PÉTER LÁSZLÓ - LADÁNYI LILI - DR. MAGYAR AdÉL DR. PUKÁNSZKY BÉLA - PORKOLÁB MIHÁLY - SALLAI ILONA ÉVA Könnyen Érthető Információs Központ (KÉIK) létesítése a szegedi

Gyógypedagógus-képző Intézetben 16

Hegedüs Hanga - dR. HoRvÁth PÉTer LÁszló - Radics MÁrta

Értelmileg akadályozott, 1-8. osztályos általános iskolai tanulók receptív nyelvi képességeinek vizsgálata a TROG-H teszt segítségével

BOROSNÉ RIMASZOMBATI DÓRA

A könnyen érthető kommunikáció és a Hublow olvasástanítási módszer

kapcsolata - egy esetismertetés tükrében 44

NÉMET BEÁTA

Hatékonyabban támogatja-e a könnyen érthetö üzenet

az értelmileg akadályozott tanuló főzési folyamatát a sztenderd üzenetnél?

KESZEY BORBÁLA

Könnyen érthető kommunikáció értelmi sérült személyekkel

Névmások használatának vizsgálata könnyen érthető

információkat tartalmazó dokumentumokban

VECSERI ZITA

Könnyen érthető kommunikáció értelmi sérült személyekkel.

A mondatok használatának vizsgálata könnyen érthető információkat tartalmazó

dokumentumokban 


\section{PESZEKI DORINA}

Kutatás a participativitás, az önérvényesítés és a könnyen érthető kommunikáció jegyében

\section{BERÉNYI ZOLTÁNNÉ}

A könnyen érthető kommunikáció mint innováció megjelenése az integrált nevelési-oktatási folyamatban

\section{SZARAPKA DÓRA}

Könnyen érthető hírek és azok készítése

\section{GALAI BIANKA}

Az ÉFOÉSZ és tagszervezeteinek törekvései

a könnyen érthető kommunikáció területén

\section{MENICH NÓRA}

AT, GYSE, IKT, AAK... Az önálló életvitelt támogató-segítő

eszközök és technológia - fogalmi tisztázás és helyzetkép

\section{LOVÁNYI ESZTER}

A segítőkutyák valóban szinte „bárhová” elkísérhetik gazdájukat? Közszolgáltatást

nyújtó intézmények képviselőivel végzett interjús vizsgálat eredményei

A negyedévente Szlovákiában megjelenő Carissimi c. ingyenes kiadvány rendszeresen közöl a könnyen érthető kommunikációval, és az értelmi sérült személyek önérvényesítésével kapcsolatos írásokat.
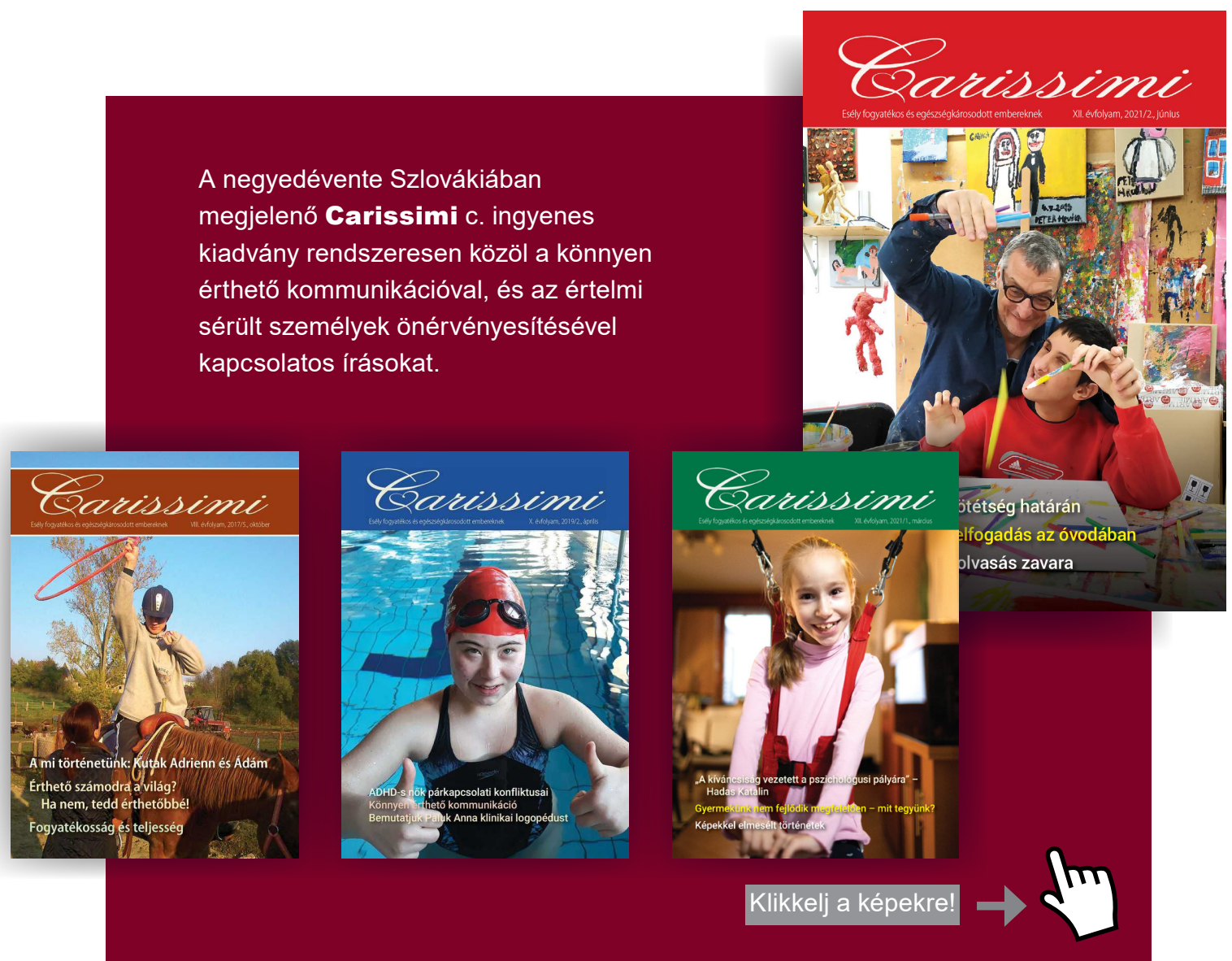


\title{
ABSZTRAKT/ABSTRACTS
}

\author{
CZIRÁKI ZSOLT - DR. HORVÁTH PÉTER LÁSZLÓ - LADÁNYI LILI - DR. MAGYAR ADÉL \\ - DR. PUKÁNSZKY BÉLA - PORKOLÁB MIHÁLY - SALLAI ILONA ÉVA
}

\author{
Könnyen Érthető Információs Központ (KÉIK) létesítése a szegedi \\ Gyógypedagógus-képző Intézetben
}

Az információs társadalom tagjaiként az információ birtoklása létszükségletté vált. Az élet minden területén szükségünk van arra, hogy jól informáltak legyünk, hiszen ezek birtokában hozzuk meg döntéseinket. Az információk nyelvi szintje általában a többséghez igazodik, így azok az értelmi sérült személyek számára nem, vagy nehezen érthetőek. Az információs akadálymentesítés egyik formája a könnyen érthető kommunikáció. 2020 és 2023 között a Szegedi Tudományegyetem a módszert magyar nyelvre adaptáló, alkalmazó és az alkalmazására való felkészítéssel foglalkozó információs központ létrehozásán dolgozik egy projekt keretében. A kutatási és innovációs projekt megvalósítása közben a szegedi Gyógypedagógus-képző Intézet számos szervezettel törekszik együttműködésre. A participativitás jegyében tapasztalati szakértők is tagjai a Tanácsadó Testületnek. Publikációnkban ismertetjük a projekt pilléreihez kapcsolódó céljainkat, valamint a vezetés és a Tanácsadó Testület feladatait. Bemutatjuk a komplex program részleteit, mint például tanulmányutak szervezése, pedagógus-továbbképzési program tervezése, akkreditációja és megvalósítása, valamint tananyagfejlesztés. Ez utóbbi elemei többek között: idegennyelvű szakirodalmi fordítások, hazai tanulmányok publikálása, egy értelmileg akadályozott tanulók kerettantervéhez igazodó képtár megalkotása, egy magyar nyelvű szabályrendszer létrehozása, ellenőrök képzése, valamint információs kisfilmek készítése. Publikációnk célja a projekt megismertetése a szélesebb szakmai és társadalmi nyilvánossággal.

Kulcsszavak: könnyen érthető kommunikáció, könnyen érthető információs központ, kutatási és innovációs projekt

\section{The establishment of an Easy-to-Read Information Centre (KÉIK) at the Special Needs Education Training Institute in Szeged}

As members of the information society, the possession of information has become a necessity of existence. We need to be well informed in all aspects of our lives as we make our decisions accordingly. The language level of information is usually in line with the mainstream society, which makes it difficult for people with intellectual disabilities to understand them. Easy-to-read communication is a possibility of providing accessible information for all. Between 2020 and 2023, the University of Szeged is working on the establishment of an information centre which adapts and applies this method to Hungarian. The Institute of Special Needs Education in Szeged is working on the implementation of the research and innovation project in cooperation with several organizations. In line with participatory approach persons with intellectual disabilities are also members of the Advisory Board. In this study we describe the objectives related to the pillars of the project, as well as the tasks of the management team and the Advisory Board. We present the project in details, such as the organization of study tours, the planning, accreditation and implementation of a teacher training program and curriculum development. The latter element include the translations of studies into Hungarian, the publication of domestic studies, the creation of an illustration gallery adapted to the curriculum of students with intellectual disabilities, the publication of guidelines in Hungarian, the training of supervisors, and the production of informational short films. The aim of our publication is to introduce the project to a wider professional and social audience.

Keywords: easy-to-read communication, Easy-to-Read Information Centre, research and innovation project

\section{Hegedűs HANGA - DR. HoRvÁth PÉTER LÁsZló - RAdics MÁRTA \\ Értelmileg akadályozott, 1-8. osztályos általános iskolai tanulók receptív nyelvi képességeinek vizsgálata a TROG-H teszt segítségével}

Az értelmileg akadályozott tanulók társadalmi életben való aktív részvételének egyik feltétele a jó kommunikációs képesség. Ennek megfelelően a gyógypedagógiai nevelés-oktatás és fejlesztés központi dokumentumai (irányelvek, kerettantervek) kiemelt hangsúlyt helyeznek a célcsoport nyelvi kompetenciájának fejlesztésére. Másfelöl a fogyatékosság értelmezésének társadalmi modellje alapján a kommunikációs helyzetben a figyelmünk fókuszába kerül a befogadó (értelmileg akadályozott személy) mellett a közlő (esetünkben a gyógypedagógus) is. Elvárássá vált, hogy a közlő az üzenetét a könnyen érthető kommunikáció írott szabályrendszere alapján a befogadó nyelvi kompetenciájához illessze. Ugyanakkor nagyon kevés hazai kutatási eredményen alapuló tudással rendelkezünk úgy az értelmileg akadályozott tanulók nyelvi kompetenciájának jellemzőiről, mint a könnyen érthető üzenet készítésére vonatkozó szabályrendszer szabályainak indokoltságáról.

A fentiek alapján úgy döntöttünk, hogy kutatást végzünk értelmileg akadályozott, 1-8. osztályos általános iskolai tanulók körében. A nyelvtani szerkezetek értését a TROG-H teszttel mértük fel két budapesti, egy kecskeméti és egy 
kiskőrösi köznevelési intézményben. Az alapsokaságot alkotó 129 föből 77 értelmileg akadályozott tanulót sikerült a kutatásba bevonni. Ebben a tanulmányban csak részeredményeket közlünk. A TROG-H teszt négy, a tagadó szerkezetek értésére irányuló blokkjának felvétele során nyert adatok elemzése alapján megállapítottuk, hogy a tagadó szerkezetek megértése komoly kihívás elé állítja az értelmileg akadályozott tanulókat. Ennek megfelelően javaslatot teszünk a tagadó szerkezetek tanításának módszerére, illetve a könnyen érthetö üzenet készítésének új szabályaira.

A Szegedi Tudományegyetem Juhász Gyula Pedagógusképző Karán 2020. szeptember 1-je és 2021. június 30-a között futó kutatási programot a magyar kormány az Új Nemzeti Kiválóság Program keretében támogatja.

Kulcsszavak: TROG-H teszt, nyelvtani szerkezetek megértése, értelmileg akadályozott tanulók beszédértése, tagadás, tagadó szerkezetek, könnyen érthető kommunikáció, könnyen érthető üzenetek készítésének szabályai

\section{The assessment of the receptive language skills of 1-8 class primary school students with intellectual disabilities, using the TROG-H test}

Good communication skills play key role in the active social life participation of people with intellectual disabilities. National education standards (guidelines, curriculum etc.) related to special needs education place emphasis on developing the language competencies of students with intellectual disabilities. On the other hand, based on the social model of disability, in the communication situation, besides the recipient (people with intellectual disabilities) we also focus on the communicator (in our case, the special education teacher). Based on the written rules of easy-to-read communication, the communicator is expected to adapt his or her message to the language competencies of the recipient At the same time, very few scientific results are available in Hungary about the characteristics of the language competencies of students with intellectual disabilities, as well as about the justification of the rules of creating easy-to-read messages.

Thus we decided to conduct a research with intellectually disabled students who attend the 1-8. grades of primary school. The assessment of the understanding of grammatical structures was carried out with the TROG-H test (Hungarian adaptation of the Test for the Reception of Grammar) in two schools in Budapest, one in Kecskemét and one in Kiskőrös. 77 students with intellectual disabilities were involved in fulfilling the test from 129 of the base population.

In this study, only partial results are reported. Based on the analysis of the data obtained from TROG-H test, 4 blocks of understanding negative structures, we found that the understanding of negative structures poses a serious challenge to students with intellectual disabilities. Accordingly, we propose a method for teaching negative structures and new rules for producing an easy-to-read message.

The research program which is implemented between $1 / 9 / 2020$ and 30/6/2021 by the Gyula Juhász Faculty of Teacher Training, Szeged University, receives grants from the New National Excellence Program.

Keywords: TROG-H test, understanding grammatical structures, speech comprehension of students with intellectual disabilities, negation, negative structures, easy-to-read communication, guidelines for creating easy-to-read messages

\section{BOROSNÉ RIMASZOMBATI DÓRA}

\section{A könnyen érthető kommunikáció és a Hublow olvasástanítási módszer kapcsolata egy esetismertetés tükrében.}

Jelen tanulmány a könnyen érthető kommunikációt kapcsolja össze a Hublow olvasástanítási módszerrel. Az elméleti részben megvizsgáltam, hogy mit mondanak az olvasás tanításáról a központi pedagógiai dokumentumok (Irányelvek, kerettanterv), mennyire segítik vagy gátolják az olvasás tágabb értelmezését.

Továbbá a két módszer részletes bemutatásán túl igyekeztem megfejteni, hogy mi a gond azokkal a szövegekkel, melyekkel a hétköznapi életben találkozunk, miért nehéz ezeknek a megértése az értelmi sérült személyek számára. Megvizsgáltam több nyelvi szintezési rendszert, ezekben kerestem az olvasás tágabb értelmezésének lehetőségét. Az elméletalkotást alátámasztom a gyakorlati tapasztalataim részletes leírásával, melyet értelmileg akadályozott gyermekek tanítása során szereztem a Hublow olvasástanítási módszert alkalmazva.

Kulcsszavak: könnyen érthető kommunikáció, Hublow módszer, nyelvi szintek, esettanulmány, olvasástanítás

\section{The case study of the relationship between easy-to-understand communication and} Hublow reading teaching method

The current study connects easy-to-read communication to the Hublow reading teaching method. In the theoretical part, I examined the content of the national pedagogical documents (Guidelines, Curriculum) related to teaching of reading, the hindering and supporting aspects to interpret reading in a wide context.

In addition to the detailed presentation of the two methods, I intend to describe the barriers of texts used in everyday life for persons with intellectual disability. I examined several systems of language competencies; I sought the possibility of a broader interpretation of reading. The theory is supported by a detailed description of my practical experience, which I obtained teaching children with intellectual disabilities using the Hublow method. 


\section{NÉMET BEÁTA}

\section{Valóban könnyebben érthetőbb-e a könnyen érthető üzenet?}

Magyarországon az értelmileg akadályozott tanulók általános iskolájában, a 6. osztályban kötelezően oktatandó ismeretkör a zacskós leves készítése. Felvetődik a kérdés, vajon képesek-e a 6. osztályos tanulók a zacskós levest a tasakon olvasható leírás alapján elkészíteni? Vajon segítséget jelent-e nekik a tanulási folyamatban, ha a zacskós leves elkészítésének folyamatát könnyen olvasható és érthető formában is rendelkezésre bocsátjuk?

Az empirikus kutatást - az érintett tanulók és szüleik írásos beleegyezésével - egy dél-alföldi szegregált iskolában végeztük el. A kutatásba 8 értelmileg akadályozott tanulót vontunk be. A zacskós levest 4 fő először a tasakon olvasható leírás, majd egy hónappal később a tanulmány szerzője által készített könnyen olvasható és érthető leírás alapján készítette el. 4 fö fordított sorrendben dolgozott. A könnyen érthető szöveges-fényképes és csak fényképes, 30 lépésből álló folyamatot bemutató recepthez a valós helyszínen készültek a fényképek. A főzési folyamat eredményességét nyilvánvalóan nem csak a recept érthetősége befolyásolja. Annak érdekében, hogy más tényezőket jó eséllyel kizárjunk, közel azonos jellemzőkkel bíró tanulókat választottunk ki. Figyelembe vettük a tanulók nyelvi kompetenciájának szintjét (tud-e olvasni), a zacskós leves készítésével kapcsolatos előzetes ismereteiket (P-A-C teszt, gyógypedagógusi interjúk, személyes megfigyelés).

A teljes főzési folyamatról videofelvétel készült. A videofelvételeket elemezve látjuk, hogy a zacskós levest a kutatásban részt vevő tanulók a tasakon lévő recept alapján, további segítség nélkül nem tudják elkészíteni. Ugyanakkor a második főzés attól függetlenül sikeresebb, hogy az első főzést a tasakon lévő vagy a könnyen olvasható és érthető recept alapján teljesítették a tanulók. A gyakorlásnak, az ismétlésnek tehát nagyobb szerepe lehet, mint magának az érthetőségnek. Ugyanakkor a könnyen olvasható és érthető recept alkalmazása egyrészt láthatóan nagyobb sikerélményt biztosít, másrészt hatékonyabban segíti elő a tanulási folyamatot a sok nehézséget és kudarcélményt okozó tasakon lévő recept alkalmazásával szemben.

Kulcsszavak: könnyen érthető kommunikáció, érthetőség, kerettanterv, felső tagozat, kutatási eredmények, zacskós leves készítése

\section{Is the message really more easy-to-read?}

The preparation of instant soups is a competence to develop obligatory at the 6th grade of the Hungarian primary schools for intellectually disabled students. The question arises as to whether 6 th grade students are able to prepare the instant soups based on the description on the bag. Whether the learning process of preparing the bagged soups is supported more adequately with easy-to-read information?

The empirical research was carried out in a special school of the Southern Great Plain Region with the written consent of the involved students and their parents. We involved eight intellectually disabled students in the research. The instant soup was prepared by four people first according to the description of the sachet and then a month later according to the easy-to-read description created by the author of the current study. Four people followed a reverse order.

The photos were taken on the real spot of the cooking. Two types of easy-to-read information of the thirtystep process were applicated: one with text and photos and another with photos. The effectiveness of the cooking process is obviously not only influenced by the availability of the recipe. In order to exclude other factors with a good chance, we selected students with nearly identical characteristics. The students' level of language competence (their reading skills) and their prior knowledge of preparing bagged soup (P-A-C test, special educational interviews, personal observation) were taken into consideration. The entire cooking process was recorded. Analyzing the videos, we observed that without further assistance the students couldn't prepare the soup solely according to the instructions of the sachets. However, the second cooking's success didn't depend on the usage of the original recipe or the easy-to-read version. Thus, practice, repetition could play a greater role than availability itself. At the same time, using an easy-to-read recipe provides greater sense of success and promotes the learning process more effectively than the original recipe that causes many difficulties and failures.

Keywords: easy-to-read communication, understandable, curriculum, lower secondary education, research results, to cook instant soup

\section{KESZEY BORBÁLA}

\section{Könnyen érthető kommunikáció értelmi sérült személyekkel - Névmások használatának vizsgálata könnyen érthető információkat tartalmazó dokumentumokban}

A könnyen érthető kommunikáció lehetővé teszi az alapvető emberi jogok biztosítását, akadálymentes és befogadó környezet megteremtését, az önáló döntéshozatalt és az önrendelkezést, valamint alkalmas az önérvényesítés támogatására. Lehetővé teszi az aktív, tudatos és valódi részvételt a társadalomban mindazok számára, akiknek a sztenderd kommunikáció megértése általánosságban vagy bizonyos helyzetekben kihívást okoz. A tanulmány célja, hogy fogyatékosságtudományi, emberi jogi paradigma felöl közelítve, a grammatika eszközeit segítségül hívva bemutassa, hogy a könnyen érthető kiadványokban hogyan alkalmazzák a szerzők a névmásokat, valamint azt, hogy a magyar nyelvű szabályrendszerek szabályai ezzel kapcsolatban milyen útmutatást nyújtanak. Fő kérdéseink, hogy a magyar nyelvű szabályrendszerekben milyen utasításokat találunk a névmások használatára vonatkozóan, illetve a könnyen érthető kiadványokban hogyan jelennek meg a névmások. A kutatás elméleti kutatómunka, összehasonlító elemzés. A kutatás eredményei lehetővé teszik, hogy a magyar nyelvű szabályrendszerekben pontosítani tudjuk a névmások használatára vonatkozó szabályokat, hiszen a jelenlegiek szubjektíven értelmezhetők, és nem elég részletesek. Ugyanakkor hangsúlyozzuk, hogy a könnyen érthető üzenet készítésekor mindig az aktuális célcsoport szükségleteit és képességeit fontos figyelembe venni.

Kulcsszavak: könnyen érthető kommunikáció, szabályrendszer, névmások, értelmi akadályozottság 


\section{Easy-to-read communication with intellectually disabled people - Studying the use of pronouns in easy-to-read documents}

Easy-to-read communication supports to ensure fundamental human rights, to create a barrier-free and accessible environment, to strengthen independent decision-making and self-determination and self-advocacy. It enables active, conscious and meaningful participation in society for all those who face difficulties in understanding standard communication in general or in certain situations. The aim of this study is to show by grammatical tools the application of pronouns in easy-to-understand publications and to present the guidelines related to the Hungarian language from Disability Studies and human rights perspective. Our main questions put in focus the instructions we can find in the Hungarian-language related to the use of pronouns, as well as the appearance of pronouns in easy-to-read publications. The research is a theoretical and comparative analysis. The results of the research allow us to specify the rules related to the application of pronouns in the Hungarian language, since the current ones can be interpreted subjectively and are not detailed enough. At the same time, we emphasize the importance of the needs and abilities of the current target group for whom we are creating an easy-to-read message.

Keywords: easy-to-read communication, guidelines, pronouns, intellectual disability

\section{VECSERY ZITA}

\section{Könnyen érthető kommunikáció értelmi sérült személyekkel A mondatok használatának vizsgálata könnyen érthető információkat tartalmazó dokumentumokban}

A tanulmány középpontjában a könnyen érthető kommunikáció áll, melynek alkalmazása és felhasználása folyamatos monitorozást igényel annak érdekében, hogy minél eredményesebb lehessen. Az eredményességet nem csupán a már elkészült könnyen érthető dokumentumok lektorálása szolgálja, hanem ezen dokumentumok alapját képező szabályrendszerek vizsgálata, finomhangolása is szükségszerü.

A könnyen érthető kommunikációról, annak szabályrendszereiről és célcsoportjának mondathasználati jellemzőiről szóló rövid elméleti összefoglaló után négy, az Inclusion Europe által kiadott „Európa nekünk” címủ könnyen érthető hírlevelének mondatai kerülnek górcső alá.

Az elméleti jellegü kutatómunkában az Inclusion Europe „Információ mindenkinek - A könnyen érthető kommunikáció európai alapelvei” című szabályrendszerét alapul véve arról gyűjtünk információkat, hogy a mintául szolgáló kiadványok mondataiban a mondathasználatra vonatkozó szabályok érvényesülnek-e, illetve a mondatok alkalmazása milyen mintázatokat mutat. A szabálypontokat külön-külön áttekintve, majd azok együttes érvényesülésére fókuszálva is megvizsgáltuk a mondatokat, a szabályrendszer betarthatóságának következetességére, illetve következetlenségére utaló jeleket keresve.

Az eredmények elemzése látható tette, hogy a vizsgált kiadványok nagymértékben törekednek a szabálykövetésre, ám az attól való eltérések is jelentősek. Az eredmények alapján lehetőség nyílik a könnyen érthető mondat alkotására irányuló szabályok pontosítására és kiegészítésére.

Kulcsszavak: könnyen érthető kommunikáció, szabályrendszer, mondatok, értelmi akadályozottság

\section{Easy-to-read communication with intellectually disabled people. Studying the application of sentences in documents that contain easy-to-read information}

The current study focus on easy-to-read communication and the continuous monitoring of its application in order to be as effective as possible. The effectiveness is improved not only by proofreading of easy-to-read documents, but also by studying and refining the rules that form the basis of these documents.

After a brief theoretical summary of easy-to-read communication, its rules and the characteristics of sentences used by intellectually disabled people, we study the sentences of four easy-to-read newsletters, called "Europe for Us" and published by Inclusion Europe.

In theoretical research Inclusion Europe's 'Information for All - European Easy-to-Read Guidelines' are considered as a starting point. We collect information on the realisation of rules related to sentences as well as the pattern of the application. Reviewing the rule points separately and together, we studied the sentences looking for signs of consistency or inconsistency in compliance with the rules. The analysis of the results made it clear that the publications in the sample made great efforts to comply with the rules, but the deviations were also significant. Based on the results, it is possible to clarify and supplement the rules for creating an easy-to-read sentence.

Keyword: easy-to-read communication, guidelines, sentences, intellectual disability 


\section{PESZEKI DORINA}

\section{Kutatás a participativitás, önérvényesítés és a könnyen érthető kommunikáció jegyében}

Jelen tanulmányban egy folyamatban lévő kutatási programot meghatározó négy gondolatkört mutatunk be: önérvényesítés, gondnoksági rendszer kritikája, participatív kutatás, könnyen érthető kommunikáció.

A kutatási program egyik újdonsága és egyben célja az, hogy a kutatási eredményekkel hozzájáruljunk az értelm sérült személyek önérvényesítő képességének fejlődéséhez. Ezt olyan módon tesszük, hogy őket kérdezzük meg a gondnokság rendszerével kapcsolatban. Másrészt a kutatási programba társkutatóként bevontunk egy olyan személyt, aki maga is egy kisvárosi lakóotthon cselekvőképességet részlegesen korlátozó gondnokság alatt álló lakója. Ezt a fogyatékosságtudományban participatív kutatásnak nevezzük. Maga a kutatás a könnyen érthető kommunikáció módszerének használatával zajlott.

Kulcsszavak: önérvényesítés, támogatott döntéshozatal, közvetlen megkérdezés, gondnokság, participatív kutatás, könnyen érthető kommunikáció

\section{Research to support participatory approach, self - advocacy and easy-to-read communication}

The current study presents four ideas that frame an ongoing research program: self-advocacy, the critical analysis of guardianship, participatory research, easy-to-read communication.

The research program as a novelty aims contributing to the development of intellectually disabled people's self-advocacy skills. We implement this by asking them about guardianship. We invited to the research program as a co-researcher, who himself is a resident of a small-town group home and lives under partial guardianship. This is called participatory research in disability studies. The research itself was conducted using an easy-toread communication.

Keywords: self-advocacy, supported decision making, asking affected persons, guardianship, participatory research, easy-to-read communication

\section{BERÉNYI ZOLTÁNNÉ}

\section{A könnyen érthető kommunikáció mint innováció megjelenése az integrált nevelési-oktatási folyamatban}

A tanulmányban - szemle jelleggel - egy falusi, tanulásban akadályozott tanulók számára inkluzív nevelést biztosító általános iskolában bevezetett módszertani innováció bemutatására kerül sor. Célunk annak szemléltetése, hogy a többségi és a tanulásban akadályozott tanulók együttoktatása hogyan valósítható meg könnyen érthető oktatási segédanyagok készítésével. A fejlesztés eredményeként átalakulhat az együttnevelést segítő pedagógus kompetenciája: a tanuló osztályközösségből történő kiemeléséről és egyéni fejlesztéséről a hangsúly áthelyeződik a többségi pedagógussal történő együttműködésre, a többségi pedagógus által az osztálytermi differenciálást lehetővé tevő könnyen érthető oktatási segédanyagok létrehozására. A tanulmányban kitérünk a tanulók tudásmérését szolgáló eszközök adaptálásának szükségességére is. A módszer alkalmazásába bekapcsolódó pedagógusok és tanulók véleménye, valamint szisztematikus megfigyeléseim alapján úgy tűnik, hogy a könnyen érthető kommunikációval a tanulók jól motiválhatók olvasási feladatok elvégzésére, eredményesebbekké válnak, fokozható a teljesítményük.

Kulcsszavak: könnyen érthető oktatási segédanyag, demokratikus jogok, esélyegyenlőség, inkluzív nevelés, együttnevelést segítő pedagógus kompetenciája, együttmüködés, innováció

\section{The emergence of easy-to-read communication as innovation related to inclusive educational process}

The study presents the review of a methodological innovation introduced in a rural primary school that provides inclusive education for students with learning disabilities. Our aim is to illustrate how inclusive education of diverse students - involving those with learning disabilities - might be achieved by creating easy-to-read teaching materials. As a result of the current development, the competencies of teachers who support inclusive education might be transformed: the emphasis shifts a) to cooperation with the mainstream classroom teacher from the separated individual development of the students; b) to create easy-to-read teaching materials that allow the mainstream teacher to differentiate in the classroom. The study also addresses the need to adapt tools for assessing students' knowledge. Based on the opinions of teachers and students involved in the application of the method, as well as my systematic observations, it seems that with easy-to-read communication, students can be well motivated to perform reading tasks, become more effective, and increase their performance.

Keywords: easy-to-read teaching material, democratic rights, equal opportunities, inclusive education, the competencies of the teacher who supports inclusive education, innovation 


\section{SZARAPKA DÓRA}

\section{Könnyen érthető hírek és azok készítése}

A tanulmányban - szemle jelleggel - nemzetközi színtérről gyűjtött példákat mutatunk be a könnyen érthető hírkészítésre, illetve ehhez kapcsolódóan ismertetem saját innovációs tevékenységemet, melyet a Vajdaságban valósítottam meg.

A könnyen érthető kommunikáció fogalma és gyakorlata már több évtizede jelen van a nemzetközi színtéren. A tömegtájékoztatáshoz füződő jog áttekintését követően a könnyen érthető hírkészítés lépéseit ismertetem. Bemutatok amerikai, német, svéd, belga és magyar jó gyakorlatokat. Szerbia még nem tartozik az Európai Unióhoz, de egy kezdeményezésnek köszönhetően már a vajdasági magyar területeken is ismerik a könnyen érthető kommunikációt, és az emberek könnyen érthető híreket olvashatnak nap mint nap a világhálón. Bízom abban, hogy a vajdasági innováció mintául szolgálhat olyan hírportálok föszerkesztőinek és újságíróinak, akik fontosnak tartják, hogy a hírek minden emberhez eljuthassanak.

Kulcsszavak: értelmi akadályozottság, könnyen érthető kommunikáció, tömegtájékoztatáshoz füződő jog, könnyen érthető hírek, külföldi jó gyakorlatok, magyarországi és vajdasági innovációk

\section{Easy-to-read news and the creation of them}

The current study gives a review of international examples related to easy-to-read news writing, and a description of my innovation activity, which was implemented in Vojvodina.

The concept and practice of easy-to read communication has been present in foreign literature and mass communication for several decades. After reviewing the rights related to mass media the steps of easy-to-read content creation is summarised. I present American, German, Swedish, Belgian and Hungarian good practices. Serbia is not a European Union member state, but as a result of a program easy-to-read communication is well known in the Hungarian territories of Vojvodina, and people have access to easy-to-read news on the World Wide Web. I hope my innovation from Vojvodina might serve as a model for editors-in-chief and journalists of news portals who intend to create new for All!

Keywords: people with intellectual disabilities, easy-to-read information, rights related to mass media, easyto- read news, good practices abroad, innovations in Hungary and Vojvodina

\section{GALAI BIANKA}

\section{Az ÉFOÉSZ törekvései a könnyen érthető kommunikáció területén}

A tanulmányban - szemle jelleggel - az ÉFOÉSZ és három tagszervezete innovációs törekvéseinek a bemutatására kerül sor. Célom annak bemutatása, hogy mi történt az elmúlt évtizedekben a könnyen érthető kommunikáció területén, illetve milyen tényezők segítik és akadályozzák a módszer hazai elterjesztését. Kitérünk a jövőre vonatkozó tervekre is.

Kulcsszavak: könnyen érthető kommunikáció, innováció, Értelmi Fogyatékossággal Élők és Segítőik Országos Érdekvédelmi Szövetsége (ÉFOÉSZ)

\section{The efforts of the Hungarian Association for Persons with Intellectual Disability (ÉFOÉSZ) to support easy-to-read communication}

The study reviews the innovation aspirations of ÉFOÉSZ and its three member organizations. My aim is to present what has happened in the field of easy-to-read communication in recent decades, and what factors support and hinder the spread of the method in Hungary. I also cover plans for the future.

Keywords: easy-to-read communication, innovation, Hungarian Association for Persons with Intellectual Disability (ÉFOÉSZ)

\section{MENICH NóRA}

\section{AT, GYSE, IKT, AAK... Az önálló életvitelt támogató-segítő eszközök és technológia - fogalmi tisztázás és helyzetkép}

A tanulmány az önálló életvitelt támogató-segítő eszközök és technológia fogalmát igyekszik tisztázni. A magyar jogszabályokban a támogató-segítő eszközök megnevezése (gyógyászati segédeszközök) és tartalma elavult, nem követi a nemzetközi trendeket és irányelveket, aminek egyik következménye, hogy az állami - társadalombiztosítási - támogatással elérhető eszközök listája jelentős elmaradásban van a piaci kínálathoz képest; ez egyik közvetett gátja az eszközök hozzáférhetőségének.

Kulcsszavak: támogató-segítő eszközök és technológia; támogató technológia; asszisztív technológia; gyógyászati segédeszköz 
AT, MD, ICT, AAC... Tools and technology to support independent living - conceptual clarification and current situation

This study aims to clarify the definition of assistive technology (AT) that support independent living. The name and definition of AT in the Hungarian legislation is obsolete and does not keep in line with the international professional definition and guidelines. Therefore, the list of state-subsidised devices lag far behind the diversity of supply on the market, by this the accessibility of assistive technology is indirectly hindered.

Keywords: assistive technology; assistive device; medical aids

\section{LOVÁNYI ESZTER}

\section{A segítőkutyák valóban szinte „bárhová” elkísérhetik gazdájukat? Közszolgáltatást nyújtó intézmények képviselőivel végzett interjús vizsgálat eredményei.}

Segítőkutya-gazdák gyakran szembesülnek azzal, hogy - a hatályos jogszabályi rendelkezések ellenére - speciálisan képzett négylábú társuk jelenléte miatt megtagadják számukra valamely (köz)szolgálatás igénybevételét. A tanulmány - segítőkutya-gazdák körében végzett, szélesebb spektrumú kutatások tanulságaira támaszkodva - közszolgáltatók képviselőivel készült 15 interjúbeszélgetést mutat be, melyek tartalmi kiértékelése MAXQDA szövegelemző szoftver támogatásával történt. A vizsgálat feltárt néhány, a konfliktushelyzetek hátterében megbúvó „sokrétü” okot is. A tanulmány, a mindenki által elfogadható megoldás elömozdítása érdekében, javaslatcsomaggal és annak realitását alátámasztó hatásútvonal-térképpel zárul. A szerzőre erősen hatott az inkluziv (emancipatív) szemléletmód, ugyanis maga is érintett személy (mindennapjait hallássérült-segitő kutya könnyíti meg), így személyes tapasztalatait is megosztja.

Kulcsszavak: segítőkutya, közszolgáltatás, egyenlő esélyü hozzáférés, inkluzív kutatások

\section{Can service dogs really accompany their owners almost "everywhere"? \\ Results of an interview-based survey carried out with the representatives of public service providers}

Service dog owners face the fact that - despite the existing legislative provisions - they are denied the use of some (public) service due to the presence of their specially trained four-legged companions. The study - based on the lessons learned from the broader spectrum studies carried out among service dog owners - presents 15 interviews and their content analysis made with MAXQDA software. The study revealed "diverse" reasons behind the conflicts. The study is closed with a proposal package and a supporting impact path map in order to facilitate a solution that is acceptable for everyone. The author was strongly influenced by the inclusive (emancipatory) approach as she is also affected (her everyday life is made easier by hearing dogs), so she shares her personal experiences as well.

Keywords: service dog, public service, equal access, inclusive research

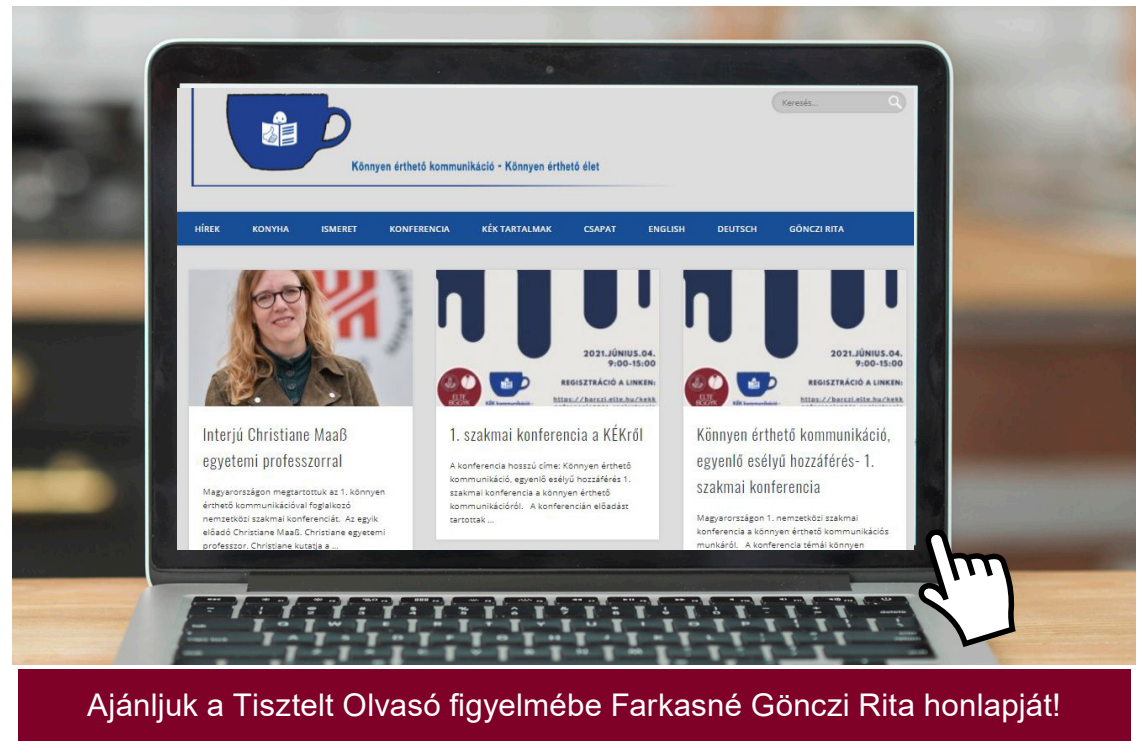




\section{DR. HORVÁTH PÉTER LÁSZLó}

\section{SZERKESZTŐI ELŐSZÓ}

Sok szeretettel és nagy várakozással ajánlom az olvasók figyelmébe a Fogyatékosság és Társadalom című folyóirat 2021. évi 1. lapszámát.

Fogyatékosságtudományi követelmény, hogy gondolatainkat a fogyatékos személyek jogaira történő hivatkozással vezessük be. Kézenfekvő, hogy a fogyatékosságügyi politika alapdokumentumának is tekinthető, a Fogyatékossággal élő személyek jogairól szóló ENSZ egyezmény idézésével kezdjünk.

A szakmai tartalom kialakításakor a fókuszba a fogyatékosságügyi ENSZ egyezmény 3. cikk, általános alapelvek f) pontjában megjelenő hozzáférhetőség elvét helyeztük. Az elv gyakorlatba ültetésének részleteiről a 9. cikkben olvashatunk. Eszerint a részes államok megfelelő intézkedéseket tesznek - többek között - az információhoz és a kommunikációhoz való hozzáférés biztosítására. Az egyezmény 2. cikke alapján a kommunikáció fogalmába tartozik - egyebek mellett - az „egyszerű szöveg” (az angol eredetiben: "plain language”). Az egyezmény más helyein előkerül a „könnyen olvasható információ" (az angol eredetiben "easy-to-read”) (9. cikk), illetve a „könynyen érthető információ" (az angol eredetiben "easy to understand) (29. cikk).

A „hozzáférés” és a „kommunikáció” fogalmának fentiek szerinti meghatározásából - álláspontom szerint - egyértelműen következik, ha bárhol a fogyatékosságügyi ENSZ egyezmény szövegében a „hozzáférhetőség” vagy a „kommunikáció” szót olvassuk, alatta a „könnyen érthető kommunikáció”-t is érthetjük.

Kifejezetten a könnyen érthető kommunikáció alkalmazása tekintetében a fogyatékosságügyi ENSZ egyezmény az élet négy területét jelöli meg. Ezek a véleménynyilvánítás és a szólás szabadsága, valamint az információhoz való hozzáférés (21. cikk), az oktatás (24. cikk), a politikai életben és a közéletben való részvétel (29. cikk), valamint a kulturális életben, üdülési, szabadidős és sporttevékenységben való részvétel (30. cikk).

Közhely, hogy minden jog éppen annyit ér, amennyi abból megvalósul. A jogok érvényesülése és érvényesítése ugyanakkor éppen rajtunk, az embereken múlik. Az első lépés a jogok megismerése és tudatosítása. A második pedig az, hogy felvértezzük magunkat az adott jog mindennapi életben történő érvényesítéséhez szükséges tudással.

A könnyen érthető kommunikációról szóló szakirodalmi források száma az elmúlt években évről évre emelkedik. Ehhez a trendhez szeretnénk hozzájárulni ezzel a tematikus lapszámmal. 
A folyóiratban 12 tanulmányt teszünk közzé, melyek közül 10 tanulmány kifejezetten a könnyen érthető kommunikációról szól, további 2 tanulmány pedig a hozzáférhetőség egyéb kérdéseivel foglalkozik.

A könnyen érthetö üzenet célja, hogy a sztenderd információk megértéséhez magas támogatást igénylő, elsősorban értelmi sérült személyek egyrészt másokhoz hasonló módon élvezhessék az olvasást, az emberiség kulturális javaihoz való hozzáférést, másrészt a megértett információk birtokában másokkal azonos alapon hozhassanak az életüket érintő döntéseket, és így gyakorolhassák az önrendelkezéshez fủződő emberi és állampolgári jogaikat.

Kétségtelen tény, hogy a könnyen érthető kommunikáció elsődleges célcsoportjának megjelölésére számos fogalom közül válogathattunk, például enyhén értelmi fogyatékos személy, középsúlyosan értelmi fogyatékos személy, tanulásban akadályozott személy, értelmileg akadályozott személy vagy éppen az intellektuális képességzavar, illetve a magas támogatási szükséglet. Ezen a helyen nincs mód arra, hogy szakirodalmi hivatkozással részletesen ismertessük az egyes fogalmak jelentését, vagy megmagyarázzuk a fogalmak jelentése közötti különbséget. Ugyanakkor azt itt jelezzük, hogy ebben a lapszámban a tanulmányok többségében a célcsoport megjelölésére az értelmi sérült személy fogalmat használjuk. Választásunk oka fogyatékosságtudományi természetű. $A$ könnyen érthető kommunikáció hazai elterjesztésére szerveződött munkacsoportunk önérvényesítéssel foglalkozó, tapasztalati szakértőnek is nevezett tagjai saját állapotuk megjelölésére ezt a fogalmat részesítik előnyben.

A továbbiakban szeretném röviden ismertetni azt, hogy miről olvashat a Tisztelt Olvasó ebben a lapszámban.

A bevezető tanulmányban a Szegedi Tudományegyetem Juhász Gyula pedagógusképző Kar Gyógypedagógus-képző Intézetében 2020. szeptember 1-jén kezdődött és 2023. december 31-ig tartó kutatási és innovációs projektjét mutatják be a szerzők. A kormányzati támogatással megvalósuló projekt végső célja az első magyarországi Könnyen Érthető Információs Központ megnyitása. A cikk szerzői: Cziráki Zsolt, dr. Horváth Péter László, Ladányi Lili, dr. Magyar Adél, dr. Pukánszky Béla, Porkoláb Mihály és Sallai Ilona Éva.

A könnyen érthető kommunikáció mint szemlélet mint módszer és mint eszköz elterjesztése igen időigényes folyamat, melyhez anyagi befektetésre és emberi erőforrásra van szükség. Vajon tényleg jobb lesz-e ettől az értelmi sérült emberek élete? Sajnos Magyarországon nagyon kevés hazai kutatási eredményen alapuló, a szakemberek számára is hozzáférhető tudással rendelkezünk. Ennek a hiányosságnak az enyhítéséhez is szeretnénk hozzájárulni azzal, hogy teret biztosítunk öt, empirikus kutatáson alapuló beszámolónak.

Hegedủs Hanga, dr. Horváth Péter László és Radics Márta értelmileg akadályozott, 1-8. osztályos általános iskolai tanulók körében végzett kutatást a TROG-H teszt segítségével, melynek célja a receptív nyelvi képességek vizsgálata. Céljuk, hogy eredményeikkel hozzájáruljanak az értelmileg akadályozott tanulók nyelvi kompetenciájának jellemzőiröl rendelkezésre álló tudás bővítéséhez, valamint a könnyen érthető üzenet készítésére vonatkozó szabályrendszer megújításához.

A köznevelési intézményrendszerben dolgozó kutatók különös tapasztalattal járulhatnak hozzá a tudásalapú társadalom megteremtéséhez. A második kutatási beszámolóban Borosné Rimaszombati Dóra a könnyen érthető kommunikáció és 
a Hublow olvasástanítási módszer kapcsolatát mutatja be a saját iskolai gyakorlatáról készített esetismertetés tükrében.

Örvendetes, hogy napjainkban egyre többen készítenek egyre több könnyen érthető oktatási segédanyagot, könnyen érthető kiadványt úgy gyermekek, mint felnőttek részére. Érezzük, hogy ez jó! De tudjuk-e biztosan, hogy az alkotó szándéka szerint könnyen érthető üzenetet az értelmi sérült személyek valóban könnyebben értik-e? Német Beáta zacskós levest fözött a zacskós leves tasakján található leírás és az általa készített, a főzési folyamatot lépésekben bemutató, könnyen érthető recept (a tanulmány melléklete) alapján készségfejlesztő iskolába járó, értelmileg akadályozott tanulókkal. Írásából az elméleti hátteret, a kutatás módszertanát és eszközrendszerét ismerhetjük meg. Bízom abban, hogy a kutatási eredmények hiányával együtt hozzájárulhatunk ahhoz, hogy a témát kutatni szándékozók a tanulmányból ötletet tudjanak meríteni.

A könnyen érthető üzenetet szabályrendszer alapján készítjük. A folyóirat megjelenésekor Magyarországon az angol nyelv sajátosságai alapján készített - a tapasztalatok alapján úgy vélem, sokszor nem egyértelmü, bizonytalanságot okozó szabályrendszer magyar fordításából dolgozunk. Ezt a szabályrendszert tanítjuk a könnyen érthető kommunikációra felkészitő képzésekben is. Ugyanakkor nem tudjuk azt, hogy a szabályokat érdemes-e betartani. Egyáltalán, a könnyen érthető kiadványok készítői vajon betartják azokat? Keszey Borbála és Vecseri Zita ennek járt utána. Az első beszámolóban a névmásokra, a másodikban a mondatokra vonatkozó szabályok kerültek nagyító alá. Kutatásuk Magyarországon első ebben a müfajban. Remélem, hogy a magyar nyelv sajátosságai alapján a szegedi munkacsoportban hamarosan elkészülő szabályrendszer tudományos vizsgálatára számos hasonló kutatás születik a közeljövőben.

Peszeki Dorina tanulmányában három, egymással szoros kapcsolatban álló fogalom kerül a gondolatmenet középpontjába: a könnyen érthető kommunikáció, a részvétel (participativitás) és az önérvényesítés (empowerment). A könnyen érthető kommunikáció a feltétele az értelmi sérült személyek társadalmi részvételének, illetve önérvényesítésüknek. Másfelől a társadalmi élet egyik lehetséges terepe az egyetemi kutatás. A kutatási folyamat során pedig lehetőség nyílik az önérvényesítésre (a jogok érvényesítésére, önálló döntéshozatalra). A nemzetközi gyakorlathoz hasonlóan, Magyarországon is egyre több, az értelmi sérült személyek életét feltáró kutatásban vesznek részt maguk az érintettek is participatív kutatótársként. Reménykedem abban, hogy ezek a fogyatékosságtudományi alapértékek egyre több szakdolgozatot készítő hallgató kutatást meghatározó értékévé válhatnak.

A kutatási beszámolókat követően a könnyen érthető kommunikáció világába kalauzoljuk a Tisztelt Olvasót. Három cikkben szemlézünk jó gyakorlatokat.

Berényi Zoltánné, Tünde egy falusi, tanulásban akadályozott tanulók számára inkluzív nevelést biztosító általános iskolában vezette be a könnyen érthető kommunikáció módszerét. Innovációjáról, úttörő munkájáról készített személyes hangvételü írását igen jó szívvel ajánlom a Tisztelt Olvasó figyelmébe. Célja annak szemléltetése, hogy a többségi és a tanulásban akadályozott tanulók együttoktatása hogyan valósítható meg könnyen érthető oktatási segédanyagok készítésével. Figyelemre méltó, hogy az együttnevelést segítő pedagógus kompetenciája a módszer bevezetésével hogyan alakulhat át. 
Szarapka Dóra ugyancsak úttörő munkát végez, példát mutatva a média szereplői számára. Írásában nemzetközi színtérről gyűjtött példákat mutat be a könynyen érthető hírkészítésre. A szabadkai székhelyű Pannon RTV online hírportálján naponta megjelenő KÉK hírekkel elsőként hozott létre Szerbiában könnyen érthető, magyar nyelvű híroldalt.

A könnyen érthető kommunikáció területén számos civil szervezet mutathat fel jó gyakorlatokat (például Down Alapítvány, Budapest; Down Egyesület, Nyíregyháza; Kézenfogva Alapítvány, Budapest). Galai Bianka az ÉFOÉSZ (Értelmi Fogyatékossággal Élők és Segítőik Országos Érdekvédelmi Szövetsége) és tagszervezeteinek törekvéseit mutatja be.

A folyóiratot Menich Nóra az önálló életvitelt támogató-segítő eszközökröl és technológiákról, illetve dr. Loványi Eszter a segítőkutyákról írt tanulmánya zárja.

Végezetül szeretném felhívni a Tisztelt Olvasó figyelmét egy hamarosan megjelenő, angol nyelvű kiadványra, melyböl 21 európai ország könnyen érthető kommunikációs gyakorlatát ismerheti meg (köztük a Magyarországét is). Lindholm, Camilla és Vanhatalo, Ulla (Finnország) szerkesztésében készült kötet várhatóan 2021 augusztusában jelenik meg.
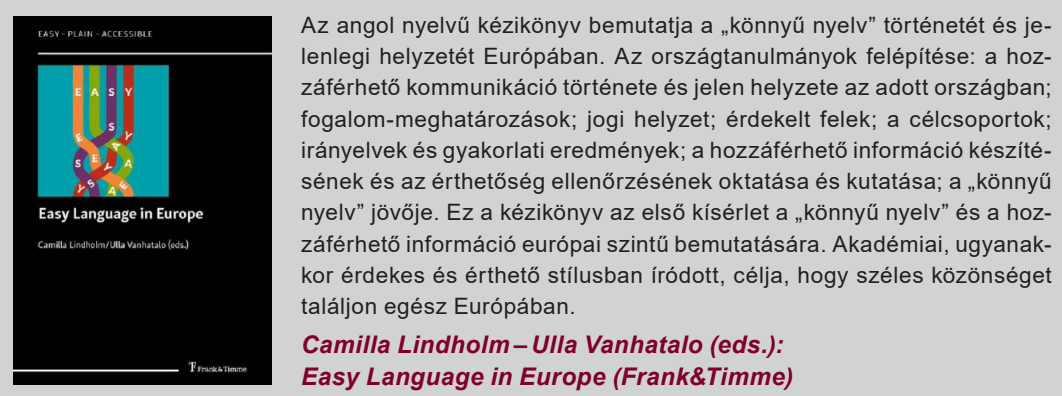
lenlegi helyzetét Európában. Az országtanulmányok felépítése: a hozzáférhető kommunikáció története és jelen helyzete az adott országban; fogalom-meghatározások; jogi helyzet; érdekelt felek; a célcsoportok; irányelvek és gyakorlati eredmények; a hozzáférhető információ készítésének és az érthetőség ellenőrzésének oktatása és kutatása; a „könnyű nyelv” jövője. Ez a kézikönyv az első kísérlet a „könnyű nyelv” és a hozzáférhető információ európai szintű bemutatására. Akadémiai, ugyanakkor érdekes és érthetö stílusban íródott, célja, hogy széles közönséget találjon egész Európában.

Camilla Lindholm - Ulla Vanhatalo (eds.):

Easy Language in Europe (Frank\&Timme)

Örömmel tölt el, hogy a szerzők munkájukkal remélhetőleg hozzájárulnak egy élhetőbb és érthetőbb világ megteremtéséhez. Köszönöm a lektoroknak, Farkasné dr. Gönczi Ritának, Ladányi Lilinek, dr. Magyar Adélnak, Pál-Horváth Ritának, dr. Radványi Katalinnak és dr. Regényi Enikőnek, hogy konstruktív szakmai javaslatokat fogalmaztak meg véleményükben. A kötet összeállításában és a szervezésben végzett munkájáért dr. Sándor Anikót és Cserti-Szauer Csillát, a szerkesztőbizottság tagjait illeti köszönet. Hálás vagyok Porkoláb Mihálynak, aki a háttérben a pénzügyek intézésével segítette a lapszám megjelenését. És végül köszönet a folyamatos együttműködésért Durmits Ildikónak, a kiadás előkészítőjének, és Borsos Szabó Ágnesnek, olvasószerkesztői és korrektori munkájáért.

Remélem, hogy a Tisztelt Olvasónak elnyeri a tetszését a Fogyatékosság és Társadalom címủ folyóirat 2021. évi jelen lapszáma.

Budapest, 2021. április 20.

Horváth Péter László (PhD), adjunktus a Fogyatékosság és Társadalom című folyóirat szerkesztőbizottságának tagja 
CZIRÁKI ZSOLT - DR. HORVÁTH PÉTER LÁSZLÓLADÁNYI LILI-DR. MAGYAR AdÉL-DR. PUKÁNSZKY BÉLA - PORKOLÁB MIHÁLY - SALLAI ILONA ÉVA

\title{
Könnyen Érthető Információs Központ (KÉlK) létesítése a szegedi Gyógypedagógus- képző Intézetben
}

\begin{abstract}
Az információs társadalom tagjaiként az információ birtoklása létszükségletté vált. Az élet minden területén szükségünk van arra, hogy jól informáltak legyünk, hiszen ezek birtokában hozzuk meg döntéseinket. Az információk nyelvi szintje általában a többséghez igazodik, így azok az értelmi sérült személyek számára nem, vagy nehezen érthetőek. Az információs akadálymentesítés egyik formája a könnyen érthető kommunikáció. 2020 és 2023 között a Szegedi Tudományegyetem a módszert magyar nyelvre adaptáló, alkalmazó és az alkalmazására való felkészítéssel foglalkozó információs központ létrehozásán dolgozik egy projekt keretében. A kutatási és innovációs projekt megvalósítása közben a szegedi Gyógypedagógus-képző Intézet számos szervezettel törekszik együttműködésre. A participativitás jegyében tapasztalati szakértők is tagjai a Tanácsadó Testületnek. Publikációnkban ismertetjük a projekt pilléreihez kapcsolódó céljainkat, valamint a vezetés és a Tanácsadó Testület feladatait. Bemutatjuk a komplex program részleteit, mint például tanulmányutak szervezése, pedagógus-továbbképzési program tervezése, akkreditációja és megvalósítása, valamint tananyagfejlesztés. Ez utóbbi elemei többek között: idegennyelvű szakirodalmi fordítások, hazai tanulmányok publikálása, egy értelmileg akadályozott tanulók kerettantervéhez igazodó képtár megalkotása, egy magyar nyelvű szabályrendszer létrehozása, ellenőrök képzése, valamint információs kisfilmek készítése. Publikációnk célja a projekt megismertetése a szélesebb szakmai és társadalmi nyilvánossággal.

Kulcsszavak: könnyen érthető kommunikáció, könnyen érthető információs központ, kutatási és innovációs projekt
\end{abstract}

Mottó: Ami a mozgássérült emberek számára az akadálymentes épület, ami a siket emberek számára a jelnyelv, az az értelmi sérült emberek számára a könnyen észlelhetö és könnyen értelmezhető információ! Akadálymentes, egyenlő esélyü hozzáférést az értelmi sérült személyeknek!

Az értelmi sérült emberek - létszámuk a 2010-es népszámlálás adatai alapján 42779 fő (Tauz \& mtsai, 2015) - nem, vagy csak nagy nehézségek árán, személyes segítséggel képesek az őket körülvevő, bonyolult világ értelmezésére. Az információ hatalom! Életünk minden területén szükség van arra, hogy jogtudatos polgárként jól informáltak legyünk, ezek birtokában hozzunk döntéseket. Az értelmi sérült személyek önérvényesítésének egyik akadálya az, hogy az információ magasabb nyelvi szinten érhető el, mint amely megértésére képesek. Problémát jelent nekik például a hivatalos ügyek intézése során használt üzenetek, a szépirodalmi művek, a hírek, az egészségügyi, munkaügyi, kulturális és politikai információk megértése. A 2010-es népszámlálás adatai alapján a kommunikációjában és az információszerzésben 58761 fő mondta magát akadályozottnak. Ez önmagában is nagy tömegnek tekinthető. Ugyanakkor valószínűsíthető, hogy a kommunikációs akadályozottságot csak azok az emberek jelölték meg, akik a kommunikációs jogaikkal és lehetősége- 
ikkel nagy mértékben tisztában vannak, gondolkodásukat a jogtudatosság jellemzi. A létszám tehát lehet ennél nagyobb. A magát értelmi sérült személyként meghatározó 42779 föből 10542 fő jelezte (24 százalék), hogy a kommunikációban és az információszerzésben akadályozott (Tausz \& mtsai, 2015). Bár a Magyarországon 2007-ben ratifikált, a Fogyatékossággal élő személyek jogairól szóló ENSZ egyezmény biztosítja a jogot az információkhoz való egyenlő esélyű hozzáféréshez az értelmi sérült személyek számára is, hiányzik az ezen jog végrehajtásához szükséges szabályozás és a finanszírozási háttér (fogyatékosságügyi ENSZ egyezmény, 2007). A könnyen érzékelhető és könnyen érthető üzenet készítésének módszertana sem terjedt el. A megyei szinten hozzáférhető jelnyelvi tolmácsszolgáltatáshoz hasonló könnyen érthető információs központok hálózatának kialakítása egyelöre a jövő feladata.

Nemzetközi színtéren létezik egy olyan írott szabályrendszeren alapuló módszer, amelynek segítségével adott nyelven belül összetettebb nyelvi szintről könnyen érthető szintre lehet fordítani az információkat, vagy eleve könnyen érzékelhetően és könnyen érthetően lehet azokat létrehozni (Inclusion Europe \& ÉFOÉSZ, 2009). Az értelmi sérült emberekben tudatosodnia kell annak, hogy ha valamit nem értenek, az nem az ő hibájuk. Törvényben garantált joguk van egy érthető világhoz. A mindennapi életben való érvényesülésüknek feltétele a jogtudatosságuk. A megoldáson, a könnyen érthető kommunikáció hazai elterjesztésén velük szoros együttmüködésben, közösen dolgozunk. Az értelmi sérült személyek információkhoz való egyenlő esélyű hozzáférését nagyban segítené egy, a módszert magyar nyelvre adaptáló, alkalmazó és az alkalmazására való felkészítéssel foglalkozó információs központ.

Magyarország Kormánya a Mórahalmi Komplex Fejlesztő Centrum létrehozásáról szóló 1264/2019. (V. 7.) számú Kormányhatározat alapján 3 kedvezményezett (Mórahalom Város Önkormányzata, Szegedi Tudományegyetem, Eötvös Loránd Tudományegyetem) számára biztosít forrást a Mórahalmi Komplex Fejlesztő Centrum létrehozására, illetve a centrum létrehozásával együtt megvalósuló oktatási, tartalomfejlesztési program kidolgozására és megvalósítására.

A Szegedi Tudományegyetem részére a Kormány 2020-2023 között összesen 252858230 Ft-os támogatást biztosít az „SZTE JGYPK képzési portfólió fejlesztése, Könnyen Érthető Információs Központ létrehozása a Szegedi Tudományegyetemen" című program megvalósítására. A szakmai program I. pillére az SZTE JGYPK Gyógypedagógus-képző Intézet képzési portfóliójának fejlesztését valósítja meg. A szakmai program II. pillére Könnyen Érthető Információs Központ létrehozását tűzte ki célul a Szegedi Tudományegyetemen - ebben a pillérben található egy építési beruházás, illetve a könnyen érthető kommunikációhoz kapcsolódó szakmai tartalmak fejlesztése is.

A program 2015. szeptember 1-töl az SZTE JGYPK Gyógypedagógus-képző Intézetében megszerzett tapasztalatokra épül. A könnyen érthető kommunikációt gyógypedagógia szakos hallgatóknak tanítottuk participatív oktatók bevonásával, kezdetben 30 órás választható tanegység keretében. Később az értelmileg akadályozottak pedagógiája szakirányon egy 60 órás tanegységbe építettük be, 30 órában kötelezö ismeretkörként (Horváth \& Magyar, 2017; Horváth \& mtsai, 2019; Horváth \& Sallai, 2020).

Innovációs programunk hozzájárul az értelmi sérült személyek életminőségének javításához. Ennek érdekében a II. pillér egymással összefüggő, három célja, hogy 
1. 2022. január 1-töl, két értelmi sérült személy foglalkoztatásával megnyissuk Magyarország első Könnyen Érthető Információs Központját az SZTE JGYPK Gyógypedagógus-képző Intézetében. A központ szolgáltatásait a CsongrádCsanád megyei, kommunikációs jogaival tudatosan élö, értelmi sérült személyek vehetik majd igénybe, ha bármilyen információt szeretnének könynyen észlelhető és könnyen érthető formában megkapni. Távlati célunk, hogy a szegedihez hasonló könnyen érthető információs irodák nyíljanak országszerte. Ebben a megközelítésben a szegedi Gyógypedagógus-képző Intézet az országos hálózat kialakításának egyik meghatározó motorja kíván lenni.

2. 2024. január 1-töl a fövárosban és minden megyében átlagosan 10 fö olyan értelmi sérült személy álljon rendelkezésre, akik tanfolyami keretek között felkészültek a könnyen érzékelhető és könnyen érthető információk érthetőségének ellenőrzésére (Horváth, 2019).

3. 2024. január 1-töl a fővárosban és minden megyében átlagosan 20 olyan gyógypedagógus dolgozzon a köznevelés intézményrendszerében, akik pedagógus-továbbképzés keretében felkészültek a könnyen érthető kommunikációnak mint módszernek az alkalmazására tanulásban akadályozott vagy értelmileg akadályozott gyermekek és tanulók körében.

A program irányítója a Szegedi Tudományegyetem Juhász Gyula Pedagógusképző Kar Gyógypedagógus-képző Intézete. A megvalósításban szorosan együttmüködünk az Értelmi Fogyatékos Személyek és Segítőik Országos Érdekvédelmi Szövetségével, az Értelmi Fogyatékosok Csongrád Megyei Érdekvédelmi Szervezete Közhasznú Egyesületével és a Csongrád-Csanád Megyei Napsugár Otthon Ásotthalmi Részlegével. Szintén tagok jelenleg - a hálózatosodás céljával - a budapesti Csalogány EGYMI, a hódmezővásárhelyi Kozmutza Flóra EGYMI, a szegedi Bárczi Gusztáv EGYMI.

A program szakmai, pénzügyi és adminisztratív vezetését 3 fös projektmenedzsment végzi. A 8 fős Tanácsadó Testület tagjai az egyetemi intézet munkatársai, illetve a partnerszervezetek képviselői. Feladatuk a koncepció kidolgozása, az egyes programok megvalósíthatósági tervének átgondolása, a megvalósítás nyomonkövetése, részvétel az eredmények disszeminálásában. A program szervezésében kiemelt szempont a részvétel joga, a bevonás kötelezettsége: így a Tanácsadó Testületnek és minden alprogramnak tagjai maguk az értelmi sérült személyek. Az értelmi sérült személyek részvétele a program minden szakaszában biztosított a koncepció kidolgozásától a legapróbb részletek megvalósításáig. A program 2020. január 1. és 2020. december 31. között már megvalósított alprogramjaiban 30 fővel dolgoztunk együtt.

Érvényesítjük a „semmit rólunk, nélkülünk” elvet. Az értelmi sérült önérvényesítőkkel közösen alakítjuk és formáljuk a program stratégiáját, annak megvalósítását és a program megvalósulásának folyamatos értékelését. Az értelmi sérült személyek fizetett munkát végeznek a programban (fejlesztőként, participatív oktatóként és kutatóként, gondoskodnak a program keretében született anyagok érthetőségének az ellenőrzéséről). A program menedzsmentje és a Tanácsadó Testület folyamatosan monitorozza a program müködését, gondoskodik a menetközben felmerülő problémák megoldásáról, a változó körülményekhez való alkalmazkodásról. Az önérvényesítők részesei a tapasztalatszerzést szolgáló nemzetközi tanulmányutaknak, teljesjogú partnerek a PR-tevékenységekben. 
Az értelmi sérült személyek felsőoktatási keretek között vesznek részt az ő tanításukra felkészült gyógypedagógusok könnyen érthető kommunikációra felkészítő továbbképzési programjának kidolgozásában, majd lebonyolításában. Másrészt ők lesznek az oktatói a sorstársaiknak szóló könnyen érthető információk érthetőségének ellenőrzésére felkészítő képzésnek is. Az ebből a képzésből elsőként kikerülő értelmi sérült önérvényesítők közül két fő vállalhat majd munkát a szegedi Könnyen Érthető Információs Központban (KÉIK-ben).

A felsőoktatási intézmény, a civil szervezetek és a szociális intézmények közötti együttműködésben tudományos kutatásokkal tervezzük biztosítani a program hatásának, a könnyen érthető kommunikáció eredményességének mérését. A program hatásaként azt várjuk, hogy a program szolgáltatásainak fejlesztésében, majd az azokban részt vevők (egyetemi oktatók, gyógypedagógusok, szociális szakemberek, önkéntesek, szülök) kompetenciái (tudás, képesség, attitűd és felelősségvállalás) fejlődnek. A participatív oktatás és kutatás mintaként szolgálhat bármely, emberekkel foglalkozó szakmára felkészítő felsőoktatási intézménynek (például szociális szakemberek, orvosok, pedagógusok képzése). A program keretében megvalósuló PR-tevékenység eredményeként hatással lehetünk a társadalmi szemléletre is.

A továbbiakban szeretnénk röviden bemutatni a komplex program egyes elemeit.

Bár vannak már olyan magyarországi eredmények, amelyekre az innovációs program építhető, szükségét éreztük annak, hogy megismerjünk két külföldi jó gyakorlatot. Ezért 2020 nyarán Ausztriában jártunk, a grazi székhelyủ Capito szervezetnél. 2021-ben pedig az augsburgi Caritas könnyen érthető információs szakcentrumát szeretnénk felkeresni.

A tanulmányutakon való részvétel lehetősége korlátozott. Annak érdekében, hogy a nemzetközi jó gyakorlatokat minél többen megismerhessék, illetve bemutathassuk a hazai eredményeket is, szeretnénk 2021-ben Szegeden megszervezni az első nemzetközi, könnyen érthető kommunikációval foglalkozó konferenciát. Ezen a ponton felhívjuk az olvasó figyelmét a nemzetközi színtéren elérhető, hasonló célú németországi és svájci konferenciákra.

Nagyon fontosnak tartjuk, hogy a könnyen érthető kommunikáció mint módszer beépüljön a tanulásban vagy értelmileg akadályozott gyermekek és tanulók fejlesztésének, oktatásának és nevelésének mindennapjaiba. Ezért tanulási eredmény alapú megközelítéssel, a munkakörelemzés eredményeire építve kidolgoztunk egy 60 órás, gyakorlatba ágyazott pedagógus-továbbképzési programot. Akkreditációja folyamatban van.

A tanulásban akadályozottak, illetve értelmileg akadályozottak pedagógiája szakirányon végzett gyógypedagógusok számára tervezett továbbképzési programunkhoz kapcsolódóan tananyagfejlesztésen is dolgozunk. Ennek keretében idegennyelvű szakirodalmi forrásokat fordítunk. Az első nyolc, szisztematikus szakirodalom-feldolgozás eredményeit, illetve kutatási eredményeket bemutató angol nyelvű tanulmány magyar fordítása szöveggyűjtemény formájában jelenik meg 2021 második negyedévében. A Fogyatékosság és Társadalom című folyóirat jelen tematikus számában kilenc olyan tanulmányt adunk közre, amelyek a könnyen érthető kommunikációval foglalkozó, alap- és mesterszinten, illetve szakirányú továbbképzés keretében készített szakdolgozatok alapján születtek. Nagyon fontosnak tartjuk, hogy olyan magyar nyelven írt szakirodalom is rendelkezésre álljon, ami kifejezetten a pedagógus-továbbképzési programhoz illeszkedik. A 2021. év végére tervezzük el- 
készíteni a magyar nyelvü, könnyen érthető üzenet készítésének a magyar nyelv sajátosságait figyelembe vevő szabályrendszerét. Dolgozunk egy kétezer elemből álló könnyen érthető képtáron is. A képtár az értelmileg akadályozott tanulók 1-8. osztályaiban használt kerettantervek alapján készül. A kerettantervekben előírt, kötelezően tanítandó fogalmakat magyarázzuk el könnyen érthető kép formájában.

A program első évében megkezdtük egy könnyen érthető kommunikációval foglalkozó intézeti szakkönyvtár kialakítását. Beszereztük a jelenleg német nyelven elérhető szakkönyveket, angol és német nyelvű szabályrendszereket, német nyelvű könnyen érthető könyveket (elsősorban a keresztény hit témakörében). A gyakorlatorientált képzést fogja szolgálni az, hogy megvásároltuk a tanulásban, illetve az értelmileg akadályozott tanulók 1-8. osztályaiban használt összes tankönyvet.

Az akkreditált pedagógus-továbbképzési programot szeretnénk minden megyében és a fövárosban is elérhetővé tenni. Célunk, hogy 20 tanfolyam keretében összesen 400 föt készítsünk fel a könnyen érthető kommunikáció módszerének mindennapos alkalmazására. A képzés eredményes akkreditációját követően, de az első továbbképzés lebonyolítását megelőzően, szeretnénk olyan képzőket képezni, akik magas szakmai színvonalon, gyakorlati tapasztalat birtokában tudják majd tudásukat átadni (képzők képzése).

További feladatunk, hogy akkreditációra előkészítsük az értelmi sérült személyeknek szóló képzési programot, melynek keretében a könnyen érzékelhető és könynyen érthető üzenetek olvashatóságának az ellenőrzésére szeretnénk őket felkészíteni. A képzési program akkreditációját követően 20 tanfolyam megszervezésére lesz lehetőségünk. Szeretnénk a fővárosban és minden megyében - helyi támogatók és önérvényesítők közreműködésével - 10-10 főt bevonni a képzésbe. Természetesen itt is feladat a tananyagok és a taneszközök fejlesztése.

A képzési programok és a könnyen érthető kommunikáció tudományos megalapozását különböző kutatási programokkal szeretnénk biztosítani. Ennek egyik első lépéseként kutatócsoportunk megismerkedett a szemkövetéses vizsgálati módszerrel a pedagógiai kutatásban.

Szeretnénk, ha a program céljait és eredményeit a szélesebb szakmai és társadalmi nyilvánosság is megismerhetné. Ennek érdekében 5 filmet készítünk (az első már elérhető ezen a linken). Létrehoztuk a program honlapját, facebook oldalát és készítettünk egy lejátszási listát is. A könnyen érthető kommunikációt népszerűsítő szórólapok és rövidebb kiadványok készítése is a terveink között szerepel. Az elmúlt időszakban felkeltettük a Kossuth Rádió és a szegedi Rádió88 érdeklődését is.

Reméljük, hogy ezen a pár oldalon is sikerült képet adnunk az SZTE JGYPK Gyógypedagógus-képző Intézetében koordinált fejlesztésről. Tegyünk együtt egy mindenki számára érthető világ megteremtéséért!

\section{Irodalom}

a Fogyatékossággal élő személyek jogairól szóló egyezmény és az ahhoz kapcsolódó Fakultatív Jegyzőkönyv kihirdetéséröl szóló 2007. évi XCII. törvény

a Mórahalmi Komplex Fejlesztő Centrum létrehozásáról szóló 1264/2019. (V. 7.) Korm. hat.

Horváth P. L. (2019). A könnyen érthető üzenet érthetőségének ellenőrzése. Carissimi, X.3:6-8.

Horváth P. L., Bercse L., Czakó T. \& Sallai I. (2019). A könnyen érthető kommunikáció inkluzív oktatása a Szegedi Tudományegyetem Juhász Gyula Pedagógusképző Karán. In Katona V., Cserti-Szauer Cs. \& Sándor A. (szerk.), Együtt oktatunk és kutatunk! Inkluzív megközelités a felsőoktatásban. ELTE Bárczi Gusztáv Gyógypedagógiai Kar, Budapest. $156-166$. 
Horváth P. L. \& Magyar A. (2017). KÉK kurzus a gyógypedagógus hallgatók képzésében Szegeden. In Tóthné Aszalai A. (szerk.), Az „ADÁS-ban” nincs zavar. VI. Válaszok a gyógypedagógiai gyakorlat kihívásaira. Szegedi Tudományegyetem Juhász Gyula Pedagógusképző Kar Gyógypedagógus-képző Intézet, Szeged. 13.

Horváth P. L. \& Sallai I. (2020). Wir unterrichten zusammen. EASIT Multiplier Event 3. Mehr Verständlichkeit für alle - Towards a better understanding. Hildesheim, Németország. https://pagines.uab.cat/easit/sites/pagines.uab.cat.easit/files/sallai_ilona_eva_horvath_peter_laszlo_easit_20200213.pdf Letöltés ideje: 2021.03.28.

Inclusion Europe \& ÉFOÉSZ (2009). Információt mindenkinek! A könnyen érthető kommunikáció európai alapelvei. Inclusion Europe - ÉFOÉSZ, Brüsszel - Budapest.

Tausz K., Bácskay A., Csordás G., Kovács B., Németh E., Panyik B. \& Tóth J. N. (2015). 2011. évi népszámlálás. 17. A fogyatékossággal élők helyzete és szociális ellátásuk. Központi Statisztikai Hivatal, Budapest.

Könnyen Érthető Információs Központ

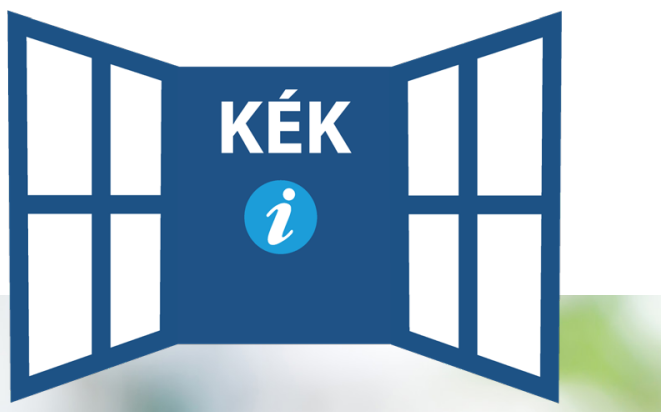

Az SZTE JGYPK Gyógypedagógus-képző Intézetében 2022. január 1-jén megnyíló Könnyen Érthetö Információs Központ logója

\section{Kövesse a Könnyen Érthető Információs Központ facebook oldalát!}

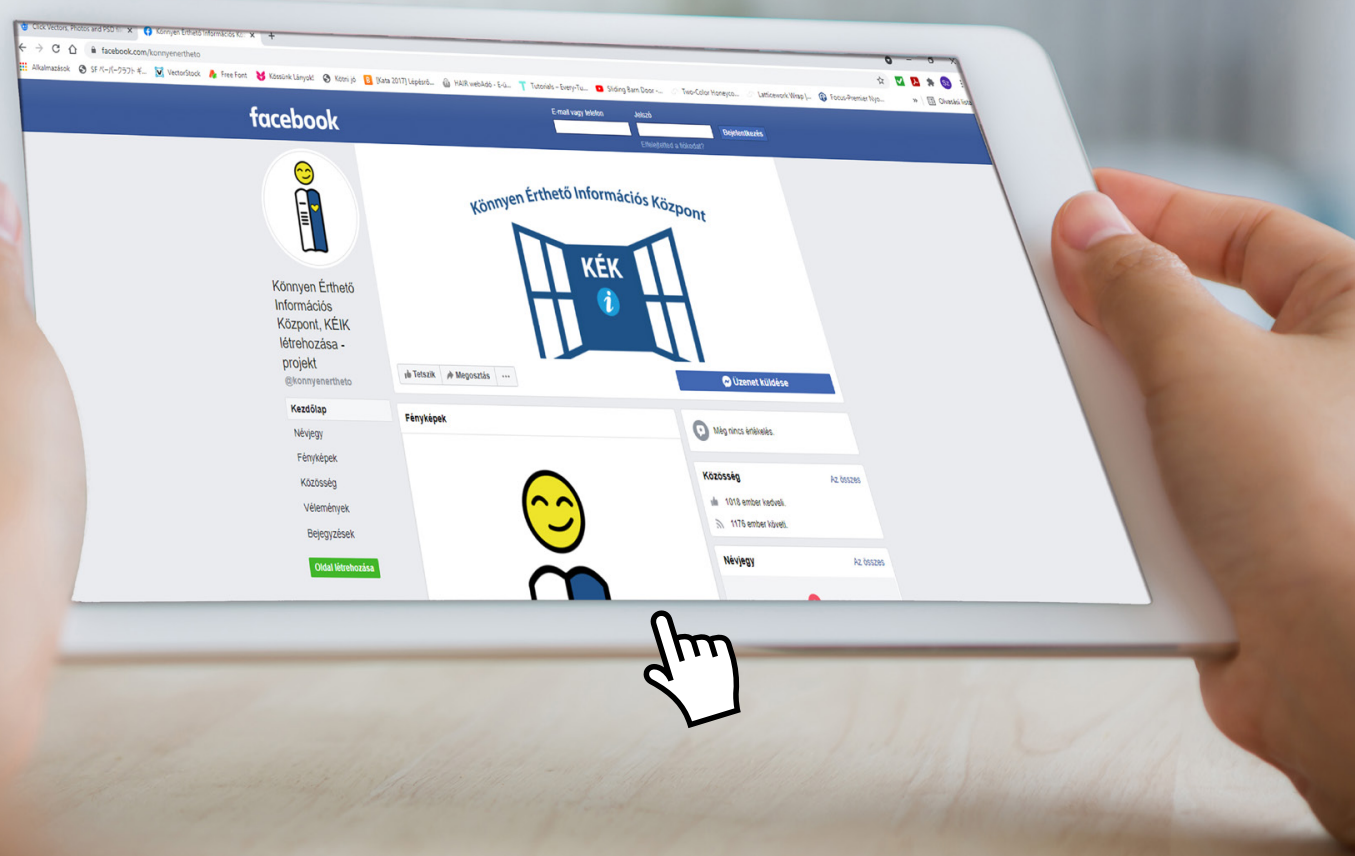




\section{Könnyen Érthető Információs Központot nyitunk Szegeden}

Akadálymentes, egyenlő esélyű hozzáférést az értelmi sérült személyeknek!

Hallottál már a könnyen érthető kommunikációról, a KÉK-ről?

A könnyen érthető információt Te is könnyen megérted.

A szegedi egyetemen, a Gyógypedagógus-képző Intézetben érted dolgozunk.

Munkánkat Magyarország kormánya támogatja.

2023. január 1-jén Könnyen Érthető Információs Központot nyitunk.

Milyen szolgáltatásokat nyújtunk majd neked?

Van valami, amit nem értesz és szeretnéd érteni?

Mi elmagyarázzuk neked.

Szeretnél könnyen érthető füzeteket és könyveket olvasni?

A Könnyen Érthető Információs Központban találsz

könnyen érthető füzeteket és könyveket.

Van egy másik célunk is.

Szerinted ki tudja megmondani,

hogy egy füzet vagy könyv tényleg könnyen érthető-e?

Egy füzet vagy könyv könnyen érthetőségét Te tudod ellenőrizni.

Szervezünk egy tanfolyamot.

A tanfolyamon megtanulhatod azt,

hogyan kell ellenőrizni a könnyen érthető füzet vagy könyv érthetőségét.

A tanfolyamon 2022. január 1-től lehet részt venni.

Ha érdekel a munkánk,

kövesd a honlapunkat vagy a facebook (féjszbuk) oldalunkat, vagy írj nekünk üzenetet!

Nézd meg a könnyen érthető kommunikációról szóló filmet! 


\section{A könnyen érthető kommunikációról és az önálló életvitelről}

Cziráki Zsolt vagyok,

a tanulmányban bemutatott projekt egyik munkatársa.

Minden évben május ötödikén ünnepeljük az Önálló Életvitel Napját.

Az Önálló Életvitel Napja alkalmából 2021. május 5-én

az Értelmi Fogyatékossággal Élők és Segítőik Országos Érdekvédelmi Szövetsége konferenciát szervezett.

A konferencián egy könyvet mutattunk be.

A könyv címe: Önálló Élet.

A könyvet önérvényesítők írták, könnyen érthető formában.

A könyvet erre a linkre kattintva olvashatod el.

A konferencián én is tartottam egy előadást.

Az előadásban a szegedi projektben végzett munkámról beszéltem.

A Szegedi Tudományegyetemen oktatod

a könnyen érthető kommunikáció módszerét gyógypedagógus

hallgatóknak.

Mit gondolsz, Zsolti, miért fontos, hogy a gyógypedagógus hallgatók ismerjék a könnyen érthető kommunikációt?

Igen, tényleg tanítok a szegedi egyetemen.

A könnyen érthető kommunikációt az egyetem oktatóival együtt tanítjuk. Ezt participatív oktatásnak nevezzük.

A participatív szóról nekem a partnerség jut eszembe. A participativitás részvételt jelent. 
Miért jó ez az oktatási forma?

Vannak olyan hallgatók,

akik még nem találkoztak értelmi sérült emberrel.

Nincs értelmi sérült családtagjuk.

Azért jó a participatív oktatás,

mert sok hallgató ilyenkor találkozik először értelmi sérült emberrel;

és nem csak a munkájuk során.

A hallgatók megismernek minket.

Megismerik a mi kommunikációs szintünket.

Az órán gyakorolják azt,

hogy úgy tudjanak beszélni,

hogy azt mi is megértsük.

A könnyen érthető kommunikációval megváltozik a hallgatók szemlélete.

A könnyen érthető kommunikáció emberközpontú megközelítés.

Emberközpontú,

mert alázatra és türelemre tanít.

Nem kell kiabálni az értelmi sérült emberrel,

ha valamit nem ért.

Megtanulják a hallgatók,

hogy másképpen fogalmazzák meg a gondolataikat, úgy, hogy azt én is megértsem.

A könnyen érthető kommunikáció olyan módszer, amivel nem mondunk le az értelmi sérült emberről. Ha például az értelmi sérült ember nem érti a munkaszerződését, akkor a munkaszerződést le lehet fordítani könnyebben érthetőre.

A könnyen érthető kommunikáció eszközt és módszert ad a hallgató kezébe. 


\section{Hogyan segíthet a könnyen érthető kommunikáció az önálló életvitelben?}

Elmesélek egy példát.

Erzsi a párom, akivel a lakóotthonban együtt élek.

Erzsinek van egy álma: szeretne önállóan zacskós levest fözni.

Erzsi a képeket jól el tudja olvasni.

Amikor a képek jó sorrendben vannak,

akkor a folyamatot is megérti.

A főzés menete például egy ilyen lépéssorozat.

A múlt héten csütörtökön négy hallgató, Erzsi és én elkészítettünk egy zacskós levest a könnyen érthető receptkönyv alapján.

A hallgatók neve: Barkász Petra, Bozóki Petra, Danka Laura és Klenóczki Petra.

A hallgatók három könnyen érthető változatot készítettek.

Erzsivel közösen megnéztük a három leírást.

Erzsi kiválasztotta a neki legjobban megfelelőt.

Volt egy 44 oldalas és egy 24 oldalas.

A harmadik is nagyon hosszú volt, terjedelmes.

Erzsi a legrövidebb változatot választotta.

A hallgatók olyan képeket használtak a receptkönyvben, amiket én készítettem a mi konyhánkban, például a tűzhelyünkről, a lábasunkról, a fakanalunkról.

A képek életszerüek, és ezért nem okoz nehézséget az értelmezésük. Így a képek Erzsinek már ismerősek voltak.

Az ismerős képek biztonságot nyújtanak a főzéskor. 


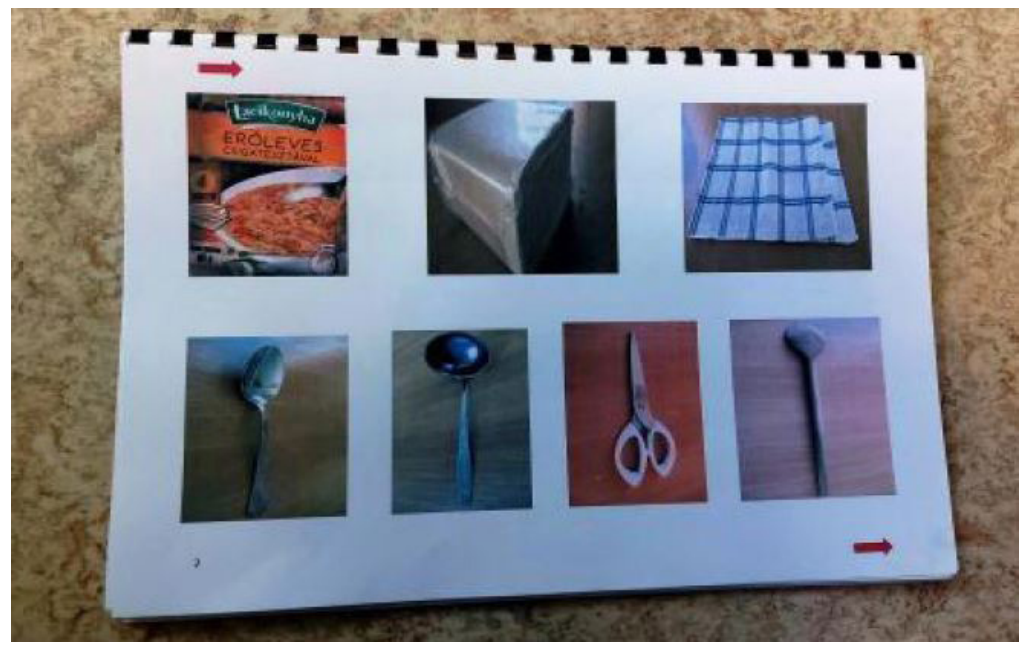

Utána kinyomtattam a receptkönyvet, és receptfüzetet készítettem belőle a lapok összefúzésével.

A konyhában előkészítettem az eszközöket.

Kiderült, hogy Erzsi a KÉK receptfüzet segítségével önállóan is meg tudta főzni a zacskós levest. Az álma teljesült.

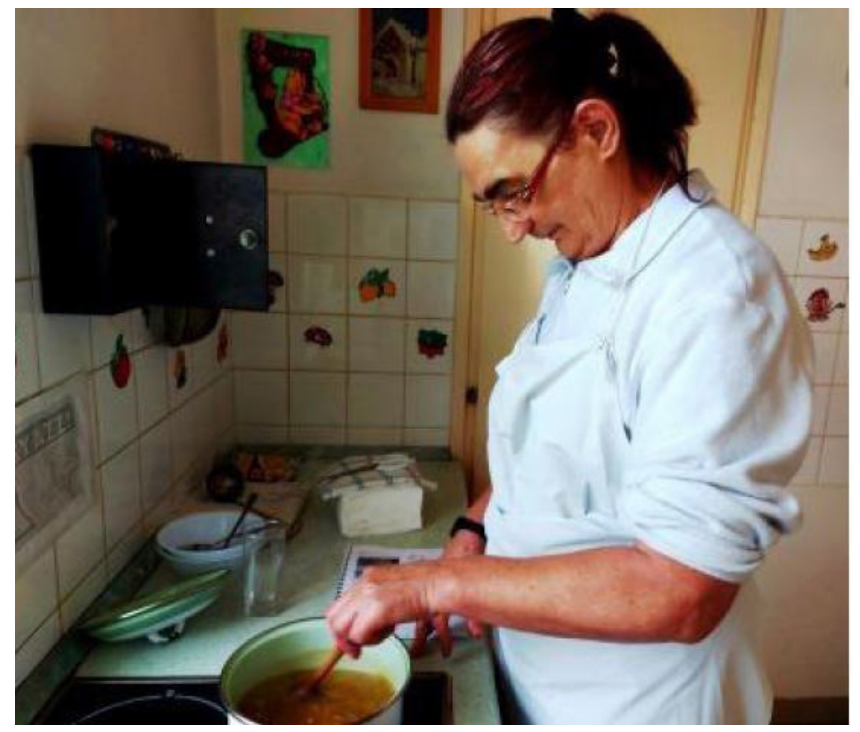


A hallgatók pedig megtapasztalták, hogy az értelmi sérült ember is képes lehet zacskós leves készítésére, ha ehhez könnyen érthető receptfüzetet készítenek neki.

Kezdetben kérdés az, hogy az értelmi sérült ember mire képes önállóan.

A csütörtöki óra is bizonyította, hogy a KÉK-kel az értelmi sérült emberek is képesek az önállóbb életre. Ehhez hitre és tudásra van szükség. Ismerd meg Te is a könnyen érthető kommunikáció módszerét!

Szeretné tudni, hogy miért jó a könnyen érthetö kommunikáció? Nézze meg ezt a filmet!

Szeretne többet tudni a szegedi Könnyen Érthetö Információs Központról? Nézze meg ezt a filmet!

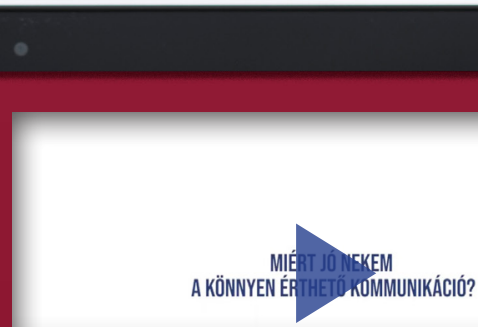

önnyen érthető inform cospont létrehozása a Szegedi Tudd nyegyetemen

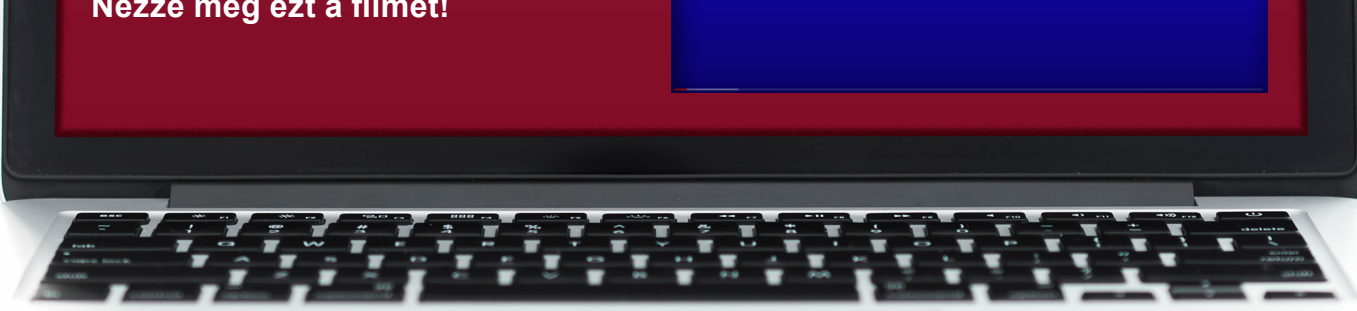


Hegedüs Hanga - dR. HORVÁth PÉTER LÁSZló RADICS MÁRTA

\title{
Értelmileg akadályozott, 1-8. osztályos általános iskolai tanulók receptív nyelvi képes- ségeinek vizsgálata a TROG-H teszt segítségével
}

\begin{abstract}
Az értelmileg akadályozott tanulók társadalmi életben való aktív részvételének egyik feltétele a jó kommunikációs képesség. Ennek megfelelöen a gyógypedagógiai nevelés-oktatás és fejlesztés központi dokumentumai (irányelvek, kerettantervek) kiemelt hangsúlyt helyeznek a célcsoport nyelvi kompetenciájának fejlesztésére. Másfelöl a fogyatékosság értelmezésének társadalmi modellje alapján a kommunikációs helyzetben a figyelmünk fókuszába kerül a befogadó (értelmileg akadályozott személy) mellett a közlő (esetünkben a gyógypedagógus) is. Elvárássá vált, hogy a közlö az üzenetét a könnyen érthető kommunikáció írott szabályrendszere alapján a befogadó nyelvi kompetenciájához illessze. Ugyanakkor nagyon kevés hazai kutatási eredményen alapuló tudással rendelkezünk úgy az értelmileg akadályozott tanulók nyelvi kompetenciájának jellemzőiröl, mint a könnyen érthető üzenet készítésére vonatkozó szabályrendszer szabályainak indokoltságáról.

A fentiek alapján úgy döntöttünk, hogy kutatást végzünk értelmileg akadályozott, 1-8. osztályos általános iskolai tanulók körében. A nyelvtani szerkezetek értését a TROG-H teszttel mértük fel két budapesti, egy kecskeméti és egy kiskőrösi köznevelési intézményben. Az alapsokaságot alkotó 129 föből 77 értelmileg akadályozott tanulót sikerült a kutatásba bevonni. Ebben a tanulmányban csak részeredményeket közlünk. A TROG-H teszt négy, a tagadó szerkezetek értésére irányuló blokkjának felvétele során nyert adatok elemzése alapján megállapítottuk, hogy a tagadó szerkezetek megértése komoly kihívás elé állítja az értelmileg akadályozott tanulókat. Ennek megfelelöen javaslatot teszünk a tagadó szerkezetek tanításának módszerére, illetve a könnyen érthetö üzenet készítésének új szabályaira.

A Szegedi Tudományegyetem Juhász Gyula Pedagógusképző Karán 2020. szeptember 1-je és 2021. június 30-a között futó kutatási programot a magyar kormány az Új Nemzeti Kiválóság Program keretében támogatja.

Kulcsszavak: TROG-H teszt, nyelvtani szerkezetek megértése, értelmileg akadályozott tanulók beszédértése, tagadás, tagadó szerkezetek, könnyen érthetö kommunikáció, könnyen érthető üzenetek készitésének szabályai

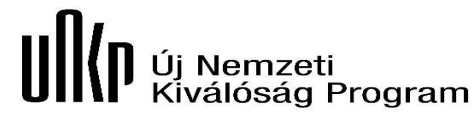

\section{BEVEZETÉS}

Az értelmileg akadályozott személyek társadalmi életben való aktív részvételének egyik feltétele a jó kommunikációs készség (Csákvári, 2006). Az előző kijelentést gyógypedagógusként olvasva figyelmünk fókuszába az értelmileg akadályozott tanulók nyelvi kompetenciájának fejlesztése kerül. És valóban: a gyógypedagógiai nevelés-oktatás tartalmát meghatározó központi dokumentumok (Irányelvek, 2020; kommunikáció kerettanterv 1-8. osztály; 2020; olvasás-írás kerettanterv 1-8. osztály, 2020) kiemelt hangsúlyt helyeznek erre a gyógypedagógusi feladatra. Az értelmileg akadályozott gyermek nyelvi kompetenciájáról szerzett tudományos ismereteknek kellene az iskolai fejlesztés, nevelés és oktatás alapjául szolgálniuk. Jelenleg 
azonban nagyon kevés magyarországi mérésen alapuló tudományos eredmény áll rendelkezésünkre (Radványi \& Pléh, 2002; Radványi, 2005; Lukács \& mtsai, 2008; Lukács \& mtsai, 2013; Lukács \& Kas, 2014).

Ennek ellenére fontos, hogy a kommunikációban részt vevő értelmileg akadályozott tanulókat felkészítsük arra, hogy magukat választékos szókinccsel, a magyar nyelv nyelvtani szabályainak tökéletesen megfelelő fogalmazásmóddal fejezzék ki. A sikeres kommunikációnak ez azonban nem a célja, hanem az eszköze. A mindennapi élet szempontjából a kommunikáció célja többek között például az, hogy szükségletünk kifejezésével a partnerünket adekvát cselekvésre bírjuk (Sápiné, 2020). Például rávegyük arra, hogy adjon nekünk egy pohár vizet. Ezt a célt elérhetjük választékos szókinccsel, grammatikailag helyesen és udvariasan megformált mondattal. Remélhetőleg hasonló eredményre jutunk akkor is, ha az üzenet lényegét kifejező szókinccsel, agrammatikusan csak annyit mondunk: „Kér víz”. És sikerrel járhatunk nonverbális (nem nyelvi) jelekkel is: a fejünkkel a vízcsap irányába biccentve, miközben a kezünkkel egy képzeletbeli poharat formázva ivó mozdulatot teszünk (Kocsisné \& mtsai, 2013).

Ugyanakkor a fogyatékosság szociális/társadalmi modellje alapján fel kell tennünk magunknak azt a kérdést is, hogy milyen környezeti tényezők akadályozzák az eredményes kommunikációt. Ebben a megközelítésben az értelmileg akadályozott emberek az információhoz való hozzáférés során azért ütköznek akadályokba, mert a többségi társadalom tagjai (esetünkben a közlök) az információt bonyolultan, nehezen értelmezhető módon fogalmazzák meg. A kommunikáció sikertelenségének oka nem (csak) az értelmileg akadályozott személy (befogadó) nyelvi kompetenciájának az átlagtól elmaradó szintjében keresendő, hanem a közlő kifejezőkészségében (Horváth, 2020a és 2020b).

Ezt ismerték fel a sajátos nevelési igényủ tanulók iskolai oktatásának irányelveit megfogalmazó szerzők is akkor, amikor a „középsúlyos értelmi fogyatékos tanulók iskolai nevelésének-oktatásának irányelvei” című fejezetben, a „Magyar nyelv és irodalom" tanulási területet érintő ajánlásokról szóló 5. 3. 1. alfejezetben, a célok és fejlesztési feladatok között a tanulási terület speciális feladatainál így fogalmaznak: „Szövegalkotáskor a könnyen érthető kommunikáció szabályaihoz kell igazodni" (Irányelvek, 2020:66). A könnyen érthető kommunikáció módszertanának szakemberek részére történő oktatása során a cél éppen az, hogy a közlő, esetünkben a gyógypedagógus megtanulja a gondolatainak a tudatos megformálását, éppen a befogadó nyelvi kompetenciájának szintjére figyelemmel. A könynyen érthető üzenet készítésekor az információt - írott szabályrendszer alapján (Inclusion Europe \& ÉFOÉSZ, 2009) - a befogadó számára érthető formába öntjük. A szabályrendszerben megfogalmazott szabályokat azonban magyarországi tudományos kutatási eredmények még nem támasztják alá (Hegedüs, 2020; Horváth, 2020c).

A fentiek alapján indokoltnak tủnt egy olyan kutatási program lebonyolítása, amelynek keretében kifejezetten az értelmileg akadályozott tanulók nyelvi kompetenciájára összpontosítunk. Reményeink szerint a kutatás eredményeit egyszerre tudjuk hasznosítani a célcsoport anyanyelvi nevelése módszertanának és a könynyen érthető üzenet készítése szabályrendszerének fejlesztésében.

A nyelvi kompetencia egy bonyolult, többrétegű fogalom. Valamennyi réteg feltárása és mérése meghaladja lehetőségeinket, és meghaladná jelen tanulmány terje- 
delmi kereteit is. Ezért ebben a tanulmányban a továbbiakban csak a tagadó szerkezetek kérdéskörével foglalkozunk; a téma szűkítését a szerzők szubjektív kutatói kíváncsisága magyarázza csupán.

\section{TAGADÓ SZERKEZET TANÍTÁSA AZ ÉRTEL- MILEG AKADÁLYOZOTT, 1-8. OSZTÁLYOS TANULÓK OKTATÁSÁHOZ KÉSZÍTETT KOM- MUNIKÁCIÓ ÉS OLVASÁS-ÍRÁS KERETTAN- TERVEK ALAPJÁN}

Az értelmileg akadályozott gyermek nyelvi fejlődését számos, egymással bonyolult kölcsönhatásba lépő belső és külső tényező formálja (Babarczy \& mtsai, 2015). Így van ez a tagadószó (például nem, sem) és tiltószó (ne, se), a tagadó jelentésủ általános főnévi (senki, semmi), melléknévi (például semmilyen, semekkora, sehány, sehol), határozószói [semmikor, soha, sehogy(an)] névmások és az egyszeres, kétszeres (például de nem; nemcsak... de; sem... sem) vagy többszörös tagadást kifejező nyelvtani szerkezetek jelentésének megértésével, ezen kifejezések alkalmazásával is (Keszler \& Lengyel, 2019). Nevezzük a fentieket együtt a továbbiakban tagadásnak.

Az egyik ilyen külső tényező a gyermek tudatos iskolai oktatása, nevelése és fejlesztése. A tagadás életkorhoz köthető tényleges tanítására vonatkozó magyar empirikus adatok és információk hiányában a tagadás tanításának megtervezését előíró dokumentumhoz tudunk csak nyúlni. A gyógypedagógus pedagógiai tervező munkáját a kerettantervek határozzák meg. Témánk szempontjából a „kommunikáció” és az „olvasás-írás” tantárgyak 1-8. osztályfokokra érvényes kerettantervei tekinthetők relevánsnak. Ezért a kerettanterveket egy nagyon egyszerü szempont szerint dokumentumelemzésnek vetettük alá: rákerestünk a „tagadó szerkezet”, a „tagadás” és a „nem” kifejezésekre. A kerettantervekben a „tagadó szerkezet” és a „tagadás” kifejezésekre egy találatot sem kaptunk. A „nem” kifejezésre keresve az olvasás-írás kerettantervben hat találatot kaptunk, de ebből egy sem volt releváns a tagadás tanításának szempontjából. A kommunikáció kerettantervben ötven találatot kaptunk a „nem” kifejezésre, amiböl tizenhárom bizonyult relevánsnak. Első, második évfolyamon a cselekvéshez kötődő „nem szabad”, „Nono!”, „nem” és a fejrázás, valamint a kívánságot kifejező „nem kérem” jelenik meg. Az „enyém” és „nem enyém” birtokos névmás tanításának a célja az enyém és a tiéd, övé elkülönítése. Harmadik és negyedik évfolyamon újra egy egyes szám első személyű, cselekvést kifejező „nem tudom megtenni”, és a viszonyulásra utaló „szeretem” - „nem szeretem”, az „ehető” - „nem ehető” kifejezéspár jelenik meg elsajátítandó fogalomként. Ötödik és hatodik évfolyamon a vásárlás témakörében, csoportosítási céllal jelenik meg a „fontos” - „nem fontos” árucikk fogalma. Végül hetedik és nyolcadik évfolyamon életszerū helyzetekben, konfliktushelyzetek felismerése és megoldási módok kitalálása okán várja el a kerettanterv egy-egy tagadó szerkezet megértését: például boltban vásárol, de nem elég a pénze az áru megvásárlására, akkor mit tegyen? Vagy a társas kapcsolatok területén magatartásszabályozási céllal kerül elő a „tudni, hogy mit tehet 
a tanuló mások előtt és mit nem" (például: diákszerelem megnyilvánulásai), illetve az „elfogadható és nem megengedhető tényezők elemzése egy kapcsolatban." Ugyanezeken az évfolyamokon a „beszédfejlesztés, anyanyelv” témakörben fejlesztési tevékenységként fogalmazódik meg, hogy a tanuló a cselekvést értékelő kérdésre állító, a valóságnak nem megfelelő kérdésekre tagadó mondatokat tudjon - immáron önállóan - szerkeszteni (kommunikáció kerettanterv 1-8. osztály, 2020; olvasás-írás kerettanterv 1-8. osztály, 2020).

Értelmezésünk szerint különösen hangsúlyossá a 7-8. osztályban válik a tagadás. Az értelmileg akadályozott tanulók 6-8 éves korukban válhatnak tankötelessé, illetve lehetősége van az iskolának arra, hogy például az első évfolyam anyagát ne egy, hanem két tanév alatt dolgozzák fel. Ezért a 7-8. osztályos tanulók 13-16 évesek lehetnek. Ezeken az osztályfokokon jelenik meg konkrétan először a beszédprodukció elvárásként: a tanuló általános módon maga is képessé kell, hogy váljon tagadást kifejező nyelvtani szerkezetek alkotására, azaz nem feltétlenül viselkedésszabályozási, viszonyulást vagy kívánságot kifejező céllal, hanem gyakorlati helyzetbe ágyazott módon.

\section{A TAGADÁSRA VONATKOZÓ SZABÁLYOK A KÖNNYEN ÉRTHETŐ ÜZENET KÉSZÍTÉSÉ- NEK SZABÁLYRENDSZERÉBEN}

Kutatásunk egyik céljaként jelöltük meg, hogy a könnyen érthetö üzenetek készítésének szabályrendszerére vonatkozóan javaslatokat teszünk. Ezért fontosnak tartjuk megvizsgálni, hogy vonatkoznak-e szabályok a tagadásra, és ha igen, akkor melyek ezek a szabályok. A tanulmány készítésekor Magyarországon az Inclusion Europe és az ÉFOÉSZ (2009) által kiadott szabályrendszert alkalmazzuk a könnyen érthető üzenetek készítésekor. A tagadásra vonatkozó szabály a szabályrendszerben nincsen.

Ugyanakkor az alkotók felhívják a figyelmet arra, hogy „Inkább pozitív tartalmú mondatokat használjunk, a negatív tartalmú helyett. Például ez egy pozitív tartalmú mondat: Itt kell maradnod addig, amíg a találkozó véget nem ér. Ez pedig egy negatív tartalmú mondat: A találkozó végéig nem mehetsz el" (Inclusion Europe \& ÉFOÉSZ, 2009:11). Benyomásunk szerint a szabályrendszer készítői nem a tagadó szerkezet megértésének a problémájából indultak ki, hanem egy pedagógiai elvböl: könnyebb azt megérteni, hogy mit tehetek, és ennek megfelelően cselekedni. Ha azt mondjuk meg például a gyermeknek az iskolában, hogy mit ne tegyen, akkor - még ha meg is érti annak a jelentését - azt nem hoztuk a tudomására, hogy mit tegyen. A fent idézett szabály ennek elkerülésére hívja fel a figyelmet.

Vegyük közben észre azt is, hogy miközben a tiltás helyett valóban megjelenik az elvárt viselkedés, tagadó szerkezet („...véget nem ér”) kerül a példamondatba. A példamondat összetett mondat (,,tt kell maradnod addig, amíg a találkozó véget nem ér."), aminek a megértése ugyancsak okozhat nehézséget. Úgy tünik tehát, hogy miközben a szabályrendszer alkotói elkerülik a tiltást, másféle nehézségek elé állítják az értelmileg akadályozott személynek üzenetet készítő szerzőket. Figyelemmel arra, hogy az Inclusion Europe és az ÉFOÉSZ (2009) szabályrendszere alapján 
kerülendő az összetett mondat, a tiltás, illetve ajánlott az üzenetet a lehető legkevesebb morfémával megfogalmazni (például „kell maradnod” helyett „maradj”), ezért megnéztük a magyar nyelvű szabályrendszer alapját képező eredeti angol nyelvű szabályrendszert is. "For example, say "You should stay until the end of the meeting" rather than "You should not leave before the end of the meeting" (Inclusion Europe, 2007:11)'. Ha minden, a fent bemutatott példa szempontjából releváns szabályt betartanánk, akkor az angol példamondatot az alábbi formában fordítanánk: „Maradj itt a találkozó végéig".

\section{A JELEN TANULMÁNY TEKINTETÉBEN MEG- VÁLASZOLANDÓ KUTATÁSI KÉRDÉSÜNK}

Mennyire sikeresen és hogyan értelmezik az értelmileg akadályozott általános iskolai tanulók a tagadó szerkezetű mondatokat? A kutatás eredményeiből milyen következtetéseket vonhatunk le a tagadó szerkezetek általános iskolai használata és a tagadó szerkezetet tartalmazó üzenet készítésére vonatkozó szabályok egyértelműsítése céljából?

A kommunikáció 1-8. osztály kerettanterv fent bemutatott elemzése alapján arra is kíváncsiak lehetünk, hogy a tagadás tervezett oktatása arra az életkorra, illetve elé vagy utána esik-e, amikor a tagadás biztos értelmezésének készsége a tanulóknál minden kétséget kizáróan megjelenik. Másképpen fogalmazva a kérdés az, hogy a kommunikáció 1-8. osztály kerettanterv készítői az értelmileg akadályozott gyermekek nyelvfejlődéséről szerzett tudományos ismereteknek megfelelően, céltudatosan tervezték-e meg a tagadás tanításának életkori sávját, vagy sajátélményű tapasztalataikra hagyatkozva helyezték el azokat az egyes osztályfokokon? Ha a tagadás kerettantervi tervezett tanításának ideje egybeesne a nevezett kompetencia tényleges birtoklásának életkori jellemzőjével, azzal igazolhatnánk vagy cáfolhatnánk azt a vélekedést, hogy az értelmileg akadályozott tanulók éppen annyira és akkor, többre vagy éppen kevesebbre képesek, mint amit a kerettantervek alapján adott életkori sávban elvárunk tőlük. A kutatási eredmények értelmezésével összefüggésben már itt meg kell azonban azt is jegyeznünk, hogy a nyelvfejlödés nem csak a tanuló érési folyamatától és a tudatos tanítástól függ, hanem például a gyermek nyelvi szocializációjától, kognitív képességeitől, intelligenciájától is.

\section{A KUTATÁS CÉLCSOPORTJA}

A kutatást értelmileg akadályozott tanulók általános iskolájában, 1-8. osztályban terveztük lebonyolítani. A COVID-19 vírushelyzetre figyelemmel személyes kapcsolati hálónkat mozgósítva választottunk ki olyan általános iskolákat, amelyek vezetése nyitott volt a kutatásban való részvételre. A mintába végül két budapesti, egy kecskeméti és egy kiskőrösi általános iskola került. Kizárólag azokat az 1-8. osztályba járó tanulókat vontuk be a mérésbe, akiknek a szakértői véleményében szerepelt a BNO F71-es kód. A kutatásból ugyanakkor kizártuk azokat az értelmileg akadályozott tanulókat, akik a BNO F71-es kód mellett autizmus diagnózissal is rendelkeztek. Az alapsokaságot - a négy iskolában - összesen 129 fö alkotta. Minden tanuló ese- 
tében küldtünk tájékoztató levelet és adatkezelési hozzájáruló nyilatkozatot a tanuló szülőjének vagy gyermekotthonban élő tanulók esetén a gyámnak. 77 tanuló szüleitől/gyámjaitól kaptunk írásos adatkezelési hozzájáruló nyilatkozatot. Ez az alapsokaság 60 százaléka. Az adatfelvételre 2020. szeptember 29-e és 2021. február 3-a között került sor.

\section{A KUTATÁs MÓdSZERE, ESZKÖZE}

Kutatásunk eszköze a standardizált TROG-H (Test for Reception of Grammar - Hungary) teszt, melynek célja a különböző nyelvtani szerkezetek megértésének felmérése 3-14 éves kor között.

Azért a TROG-H tesztet választottuk, mert Lukács és mtsai (2013:2) szerint a TROG-H tesztnek „az elméleti érdekességen kívül a gyakorlati jelentősége is nagy lehet, (...) a gyerekeknek szóló (például tankönyvi) nyelvezet kialakításában” is. Mint azt a Bevezetés című fejezetben kifejtettük, célunk ehhez nagyon hasonló: a kutatás eredményei alapján javaslatot szeretnénk megfogalmazni részben az értelmileg akadályozott tanulók nyelvi kompetenciája fejlesztésének módszertanára, részben a könnyen érthető üzenetek készítésének szabályaira vonatkozóan. Már itt jelezzük, hogy éppen ezért az eredmények bemutatásáról szóló fejezetben - figyelemmel jelen tanulmány keretében megválaszolható kutatási kérdésre - arra fókuszálunk, hogy mi jellemzi a tanulók teljesítményét a tagadó szerkezet értelmezését mérő itemekben, és nem vetjük majd össze a tanulók pontszámait a standard pontokkal.

Az eredeti tesztet angol nyelven Dorothy V. M. Bishop dolgozta ki (Bishop, 1983), majd a teszt magyar adaptációját Lukács Ágnes, Győri Miklós és Rózsa Sándor végezték (Lukács \& mtsai, 2011). A teszt alkalmazható a nyelvfejlődési zavart mutató gyermekek receptív nyelvi sajátosságainak felmérésére, továbbá a siketség, értelmi sérülés és a cerebrális parézis vizsgálatában, illetve felnőttkorban afázia esetén is. Az eljárás többszörös választáson alapuló egyéni vizsgálómódszer, ami összesen 18 blokkot tartalmaz, a blokkok pedig különböző nyelvtani szerkezetek megértését mérik (1. táblázat).

„Minden nyelvtani szerkezet megértésének vizsgálatához 4 olyan tétel (item) tartozik, amelyekhez egyenként 4 válaszlehetőség társul. Ennek alapján 0,4 százalék a valószínűsége annak, hogy a gyermek véletlenszerű mutogatással mind a 4 tételre helyesen válaszoljon" (Lukács \& mtsai, 2011:9). A vizsgált személynek itemenként rámutatással kell kiválasztania a négy kép közül azt, amelyikre a vizsgálatvezető által felolvasott mondat vonatkozik, azaz a vizsgált személytől nem igényel beszédet. A tesztmondatok korlátozott szókincsre épülnek. Ennek célja, hogy minimalizálja annak az esélyét, hogy a vizsgált személy azért ad hibás választ, mert nem érti a szavak jelentését (Lukács \& mtsai, 2011). A TROG-H tesztkönyvet és a kézikönyvet, valamint a vizsgálati ürlapokat az OS Hungary Kft.-től vásároltuk meg az Új Nemzeti Kiválóság Program (ÚNKP) keretében. 


\begin{tabular}{|c|c|}
\hline Blokk & Vizsgált nyelvtani szerkezet (példamondat) \\
\hline $\mathbf{A}$ & Főnév \\
\hline B & Ige \\
\hline C & Melléknév \\
\hline D & $\begin{array}{l}\text { Kételemü kombináció } \\
\text { (pl.: A macska szalad./A sárga motor.) }\end{array}$ \\
\hline $\mathbf{E}$ & $\begin{array}{l}\text { Tagadás } \\
\text { (pl.: A macska nem játszik.) }\end{array}$ \\
\hline $\mathbf{F}$ & $\begin{array}{l}\text { Háromelemű kombináció } \\
\text { (pl.: A macska megy a járdán.) }\end{array}$ \\
\hline G & $\begin{array}{l}\text { Egyes/többes számú személyes névmás } \\
\text { (pl.: A cica keresi őket.) }\end{array}$ \\
\hline H & $\begin{array}{l}\text { Felcserélhető szereplök } \\
\text { (pl.: A fiú nézi a cicát.) }\end{array}$ \\
\hline $\mathbf{J}$ & $\begin{array}{l}\text { Egyes/többes számú fönévrag } \\
\text { (pl.: A cica fellöki a cserepeket.) }\end{array}$ \\
\hline $\mathbf{K}$ & $\begin{array}{l}\text { Középfok/felsőfok } \\
\text { (pl.: A pohár magasabb, mint a kosár.) }\end{array}$ \\
\hline M & $\begin{array}{l}\text { Téri ragok (-ban és -on) } \\
\text { ( } p l .: \text { A cica a vonaton van.) }\end{array}$ \\
\hline $\mathbf{N}$ & $\begin{array}{l}\text { Középre beágyazott mellékmondat, alany-alany } \\
\text { (pl.: A cica, ami a kosárban van, az fekete.) }\end{array}$ \\
\hline 0 & $\begin{array}{l}\mathrm{X} \text {, de nem Y } \\
\text { (pl.: A kutya szalad, de az egér nem.) }\end{array}$ \\
\hline $\mathbf{P}$ & $\begin{array}{l}\text { Fölött és alatt } \\
\text { (pl.: A könyv a pohár alatt van.) }\end{array}$ \\
\hline $\mathbf{Q}$ & $\begin{array}{l}\text { Nemcsak } \mathrm{X} \text {, de } \mathrm{Y} \text { is } \\
\text { (pl.: A kosár nemcsak kicsi, de fekete is.) }\end{array}$ \\
\hline $\mathbf{R}$ & $\begin{array}{l}\text { Jobbra beágyazott mellékmondat, alany-X } \\
\text { (pl.: A madár azt a magot eszi, ami fekete.) }\end{array}$ \\
\hline $\mathbf{s}$ & $\begin{array}{l}\text { Sem } X, \text { sem } Y \\
\text { (pl.: A kosár se nem kicsi, se nem barna.) }\end{array}$ \\
\hline $\mathbf{T}$ & $\begin{array}{l}\text { Középre beágyazott mellékmondat, } \mathrm{X} \text {-alany } \\
\text { (pl.: A ló, amit a fiú etet, az nagy.) }\end{array}$ \\
\hline
\end{tabular}

1. táblázat. A TROG-H teszttel vizsgált nyelvtani szerkezetek a szerzők példamondataival, közzététel a Giunti Psychometrics Hungary Kft. engedélyével

\section{A KUTATÁSI EREDMÉNYEK BEMUTATÁSA ÉS ÉRTELMEZÉSE}

Ahogyan arra korábban már utaltunk, ebben a tanulmányban kizárólag azokat a blokkokat elemezzük, amely blokk nyelvi szerkezetében megjelenik a tagadás valamilyen formában. Tagadó szerkezetű mondat megértését vizsgálja az E blokk (tagadás), az $O$ blokk ( $X$, de nem $Y$ ) és a $Q$ blokk (nemcsak $X$, de $Y$ is), valamint az $S$ blokk (sem $\mathrm{x}$, sem $\mathrm{Y})$.

A kommunikáció és az olvasás-írás 1-8. osztály kerettantervek fentiekben bemutatott fókuszált elemzésével úgy véljük, hogy nem kerültünk közelebb a célunkhoz. Valójában a tagadás feltárt kerettantervi előfordulásai nem feleltethetők meg 
egyértelműen a TROG-H tesztben elvárt blokkok (azon belül itemek) szerkezeteinek. Ez alól kivételt az E blokk (tagadás) jelent. A további tagadást kifejező $(\mathrm{O}, \mathrm{Q}$ és S) blokkoknak megfelelő nyelvi szerkezetek a kerettantervekben egyértelműen azonosítható módon nem jelennek meg. És itt megint hangsúlyozzuk azt is: arról, hogy a gyógypedagógusok mikor, mit és milyen módon valósítanak meg a kerettantervi szabályozásból, nincs empirikus kutatáson alapuló tudásunk. Ezt a szálat ezért egyelöre el kell engednünk.

Az eredmények értelmezéséhez elengedhetetlen információ, hogy a TROG-H tesztfelvételt a tesztkönyvben (Lukács \& mtsai, 2011) rögzített tesztfelvételi szabályok szerint végeztük. Így nem minden tanulóval vettük fel mind a 18 blokkot, hanem a teljesítményük alapján különbözö blokkoknál állítottuk le a tesztfelvételt. Egy blokknak tekintünk egy 4 itemböl álló sorozatot, amely ugyanannak a szerkezetnek a megértését vizsgálja. A tesztfelvételi szabályok alapján az a tanuló teljesítette az adott blokkot, aki a blokkban szereplő 4 itemből mindegyikre helyes megoldást adott. Amikor egy adott blokkban akár csak egy item esetén nem jó a megoldás, akkor az adott blokkot nem teljesítettnek kell tekinteni. Ha egy tanuló egymást követő 5 blokkot ebben az értelemben nem teljesít, akkor a tesztfelvételt abbahagyjuk, és a további blokkokat ezzel a tanulóval már nem vesszük fel. Abban az esetben is abbahagyjuk a tesztfelvételt, ha a tanuló 8 egymást követő itemre nem ad választ, azaz egy képre se mutat rá a vizsgálatvezető felszólítása ellenére (Lukács \& mtsai, 2011). Kutatásunk során az „A” és a „B” blokkot minden tanulóval felvettük (77 fö), majd a tesztfelvételt a leírtaknak megfelelően szakítottuk meg. A következő diagramban bemutatjuk, hogy az egyes blokkokat hány tanulóval vettük fel.

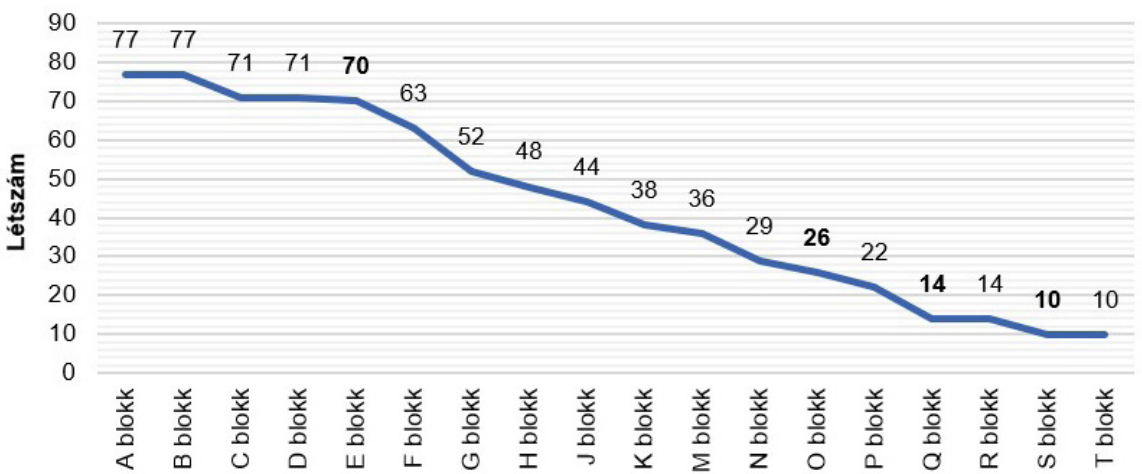

1. diagram. Az adott blokkot teljesítő tanulók száma

Az 1. diagramon megfigyelhetjük, hogy a tagadást kifejező $E$ blokkig 70 , az $O$ blokkig már csak 26, a Q blokkig 14, a S blokkig pedig 10 tanuló jutott el, amelyböl arra is következtethetünk, hogy az egyre bonyolultabb nyelvtani szerkezetek (lásd: 1. táblázat) pontos értelmezése egyre nagyobb kihívást jelent a tanulóknak.

Az eredmények értelmezése elött adattisztítást végeztünk. A kutatásban részt vevő 77 tanulóból 7 tanuló nem jutott el az „E” (tagadás) blokknak a kitöltéséig. Mivel az „E” az ötödik blokk, ez csak abban az esetben volt lehetséges, amikor a tanuló nyolc egymást követő item esetén nem adott választ. A hétből hat tanuló egyszer 
sem mutatott rá az első négy blokkban egy képre sem; egy tanuló pedig csupán egy esetben mutatott rá egy képre. Ők tehát nem voltak bevonhatók a tesztfelvételi helyzetbe, aminek csak az egyik lehetséges oka a beszédértés elmaradása. A tölük kapott eredményeket ezért ebben a tanulmányban nem elemezzük. Így a tagadást tartalmazó blokkokat elemző fejezetekben 70 tanuló eredményeit mutatjuk be (ez a kutatásba bevont tanulók 91 százaléka).

A 70 tanuló életkori összetételét a 2. diagramban ábrázoljuk.

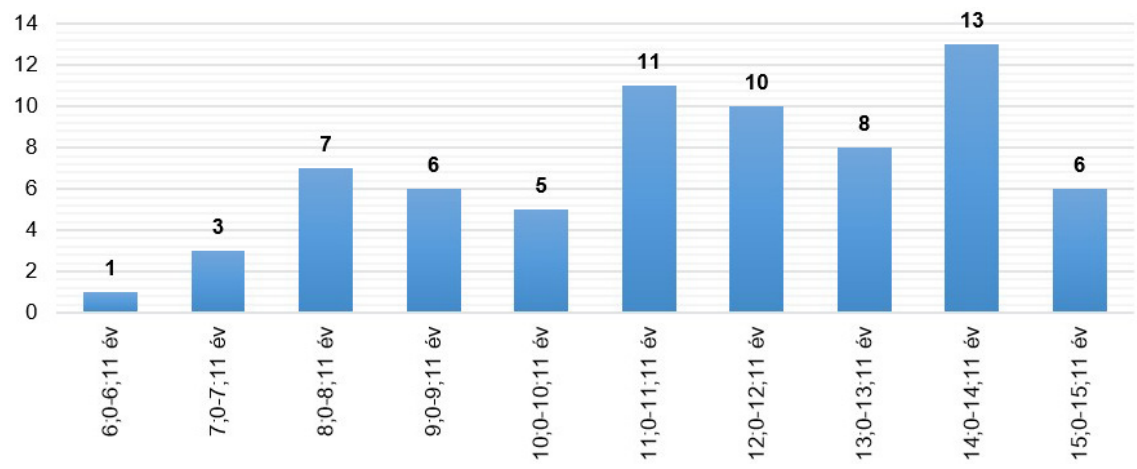

2. diagram. Az elemzésbe bevont tanulók életkori eloszlása

A 2. diagram alapján látható, hogy a különböző életkori övezetekböl bevont tanulói létszám nagyon különböző (1-13 fö). Ezért az életkori adatok alapján történő elemzés csak nagyobb minta alapján, egy későbbi kutatás keretében lesz elvégezhető.

\section{Tagadás (E blokk) eredményeinek bemutatása és értelmezése}

Az E blokkot teljesítő 70 tanuló eredményét három kategóriába soroltuk: (1) érti az adott nyelvtani szerkezetet; (2) kialakulóban van a nyelvtani szerkezet megértése; vagy (3) nem érti a nyelvtani szerkezetet. Azok a tanulók, akik 4/4 helyes választ adtak az adott blokkban, értik az adott nyelvtani szerkezetet. Akiknél kialakulóban van az adott nyelvtani szerkezet megértése, azok blokkonként változó számú - egy, kettő vagy legfeljebb három - hibát ejtettek. Ez azt jelenti, hogy „a gyermek már rendelkezik valamilyen ismerettel a vizsgált nyelvtani szerkezettel kapcsolatban, de ez a tudás még nem kialakult, a teljesítménye ingadozik" (Lukács \& mtsai, 2011:36). Azokról a tanulókról mondható el, hogy nem értik az adott nyelvi szerkezetet, akik mind a négy esetben rossz választ adtak, azaz rossz képre mutattak vagy nem mutattak rá egy tesztképre sem az egyes itemek esetén (Lukács \& mtsai, 2011). Az O, a $Q$ és az $S$ blokkok esetében a következő fejezetben is azonos módon mutatjuk be a kapott adatokat.

Az egyszerű tagadó szerkezet értését mérő „E” blokkot 25 fő (36 százalék) érti, azaz ök adtak mind a 4 tesztmondatra helyes választ. Kialakulóban van a nyelvtani szerkezet megértése 36 fö (51 százalék) esetében. 9 tanuló (13 százalék) nem adott 


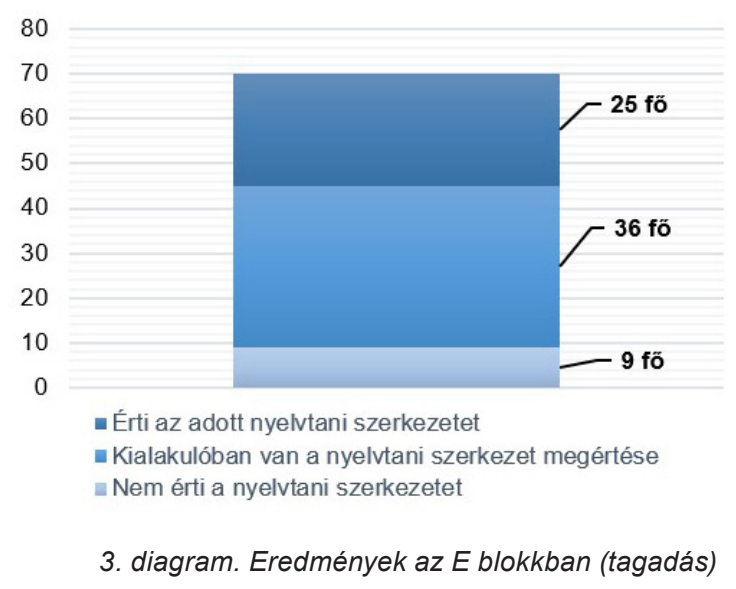

jó választ, azaz nem értik a tagadó nyelvi szerkezetet (3. diagram). Ezek az eredmények azt jelzik, hogy még az egyszerü tagadó szerkezet tudatos tanítása is fontos feladata kell legyen a gyógypedagógusnak.

A TROG-H teszt E blokkjának felvétele során nyert adatok lehetővé teszik, hogy itemenként is megvizsgáljuk, a tanulók hány esetben vétettek lexikális hibát, és hány esetben grammatikait. A továbbiakban bemutatásra kerülő grammatikai/lexikai hibák könnyebb értelmezhetösége érdekében most bemutatjuk a 17. tesztmondathoz tartozó képet (1. sz. kép).

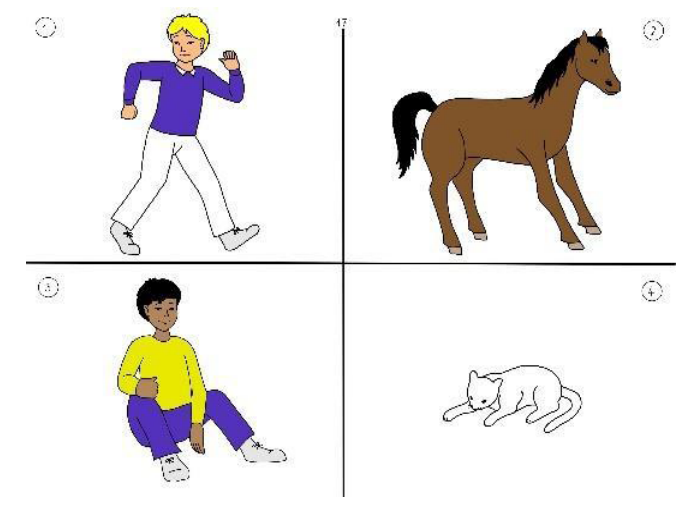

1. sz. kép. TROG-H tesztkönyv 17. képsor („A fiú nem fut.”).

A kép nem azonos a tesztkönyvben szereplő képpel. Az itt közzétett képet rajzolta: Aigner Petra. Közzététel: a Giunti Psychometrics Hungary Kft. engedélyével.

Ennél az itemnél a 3-as kép a helyes megoldás (A fiú nem fut.). Az 1-es kép a grammatikai elterelő (A fiú fut, és nem ül.) A 2-es és a 4-es képek lexikai elterelők (nem fiút látunk a képen, hanem lovat, illetve cicát).

Az alábbi diagramon az $\mathrm{E}$ blokk mind a 4 itemje esetében láthatóvá tesszük a grammatikai, illetve a lexikális hibát vétők arányát. 


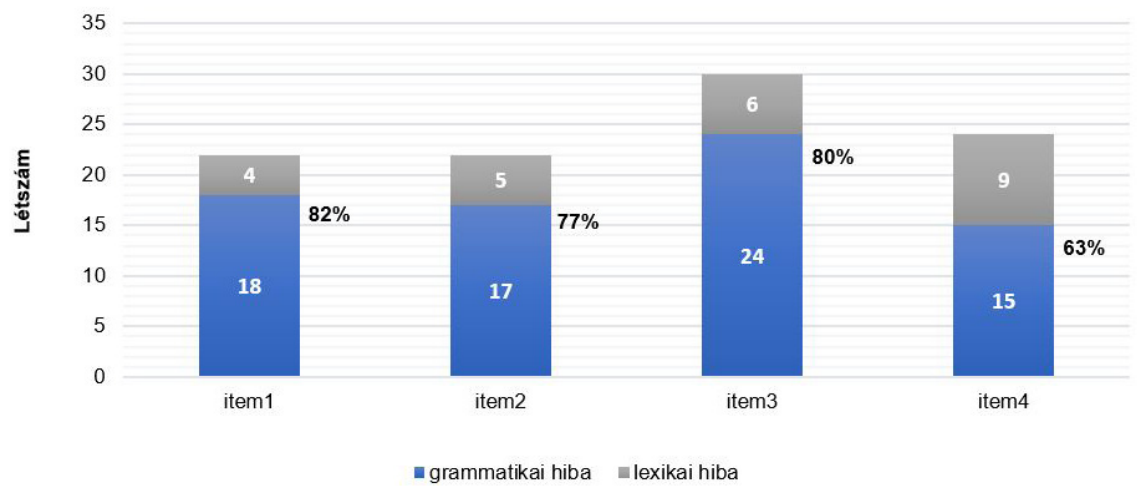

4. diagram. A grammatikai és a lexikai hibák aránya

A 4. diagramon látható, hogy az $E$ blokk minden iteme esetében jelentősen nagyobb arányban (82, 77, 80 és 63 százalékban) grammatikai hiba okozta a rossz választ, ami arra utal, hogy a mondatban szereplő szavak jelentését a tesztalanyok megértették. A nehézséget tehát a tagadás értelmezése okozta.

\section{Az O blokk (X, de nem Y), Q blokk (nemcsak X, de $Y$ is) és az $S$ blokk (sem $X$, sem $Y$ ) eredményeinek bemutatása}

Az O blokk kitöltéséig a 70 föből 26 fő (37 százalék), az Q blokkig 14 fő (20 százalék), az S blokkig pedig 10 fö (14 százalék) jutott el.

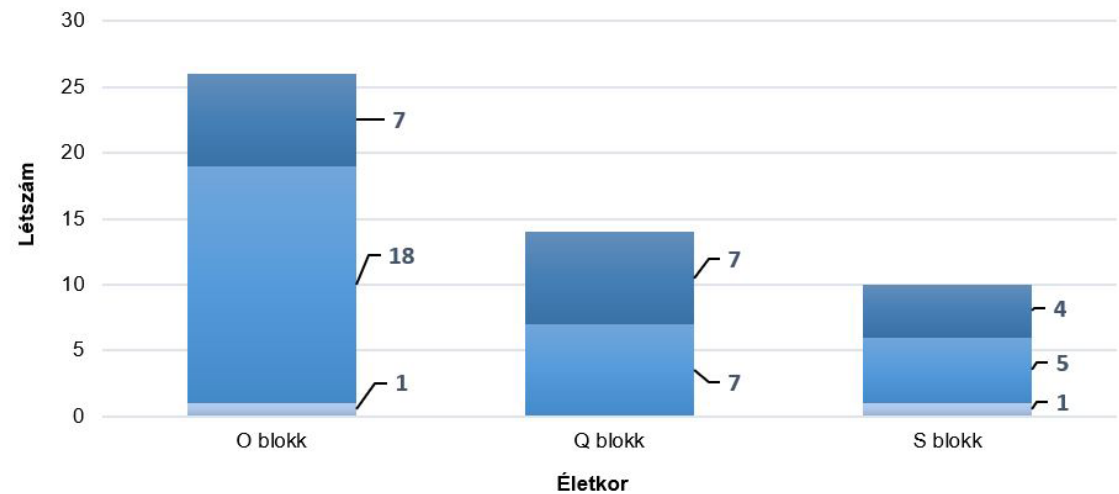

-Nem érti a nyelvtani szerkezetet

- Kialakulóban van a nyelvtani szerkezet megértése

-Érti az adott nyelvtani szerkezetet

5. diagram. Eredmények az $O$, a $Q$ és az S blokkban 
Az 5. diagramról leolvasható, hogy a „X, de nem Y” szerkezetű mondatokat (O blokk) hét fő érti, további 18 tanulónál kialakulóban van a nyelvtani szerkezet megértése, és egy tanuló nem érti ezt a nyelvtani szerkezetet. $A$ "nemcsak $X$, de $Y$ is” ( $Q$ blokk) szerkezetű mondatokat hét fő érti, hét tanulónál kialakulóban van a nyelvtani szerkezet megértése, és azon tanulók között, akik eljutottak idáig a tesztfelvételben, nincs olyan, aki nem érti ezt a szerkezetet. A „sem x, sem Y” (S blokk) szerkezetű mondatokat négy fö érti, további öt tanulónál kialakulóban van a nyelvtani szerkezet megértése, egy tanuló pedig nem érti ezt a nyelvtani szerkezetet.

$\mathrm{Az} \mathrm{O}, \mathrm{a} \mathrm{Q}$ és az S blokkban nincs lexikai elterelő, így minden tévesztés grammatikai tévesztésnek minősül.

Végezetül közöljük az adott blokkot teljesítő, illetve az adott nyelvtani szerkezetet értő tanulók számát.

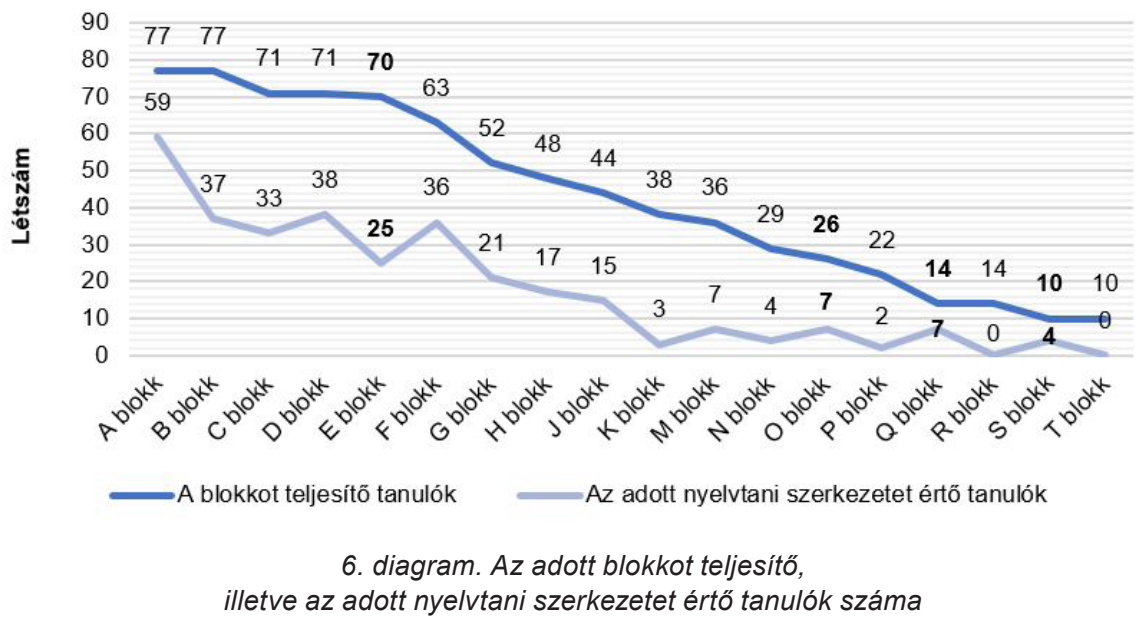

\section{ÖSSZEFOGLALÁS}

Az előző fejezetben bemutatott adatok igazolni látszanak azt, hogy a tagadó szerkezetű mondatok értelmezése valóban nehézséget okoz az értelmileg akadályozott tanulóknak. Bár az egyszerű mondatban megjelenő tagadást ( $E$ blokk) a tanulók 36 százaléka (25 fö) érti, az összetett mondatban megjelenő, bonyolultabb szerkezetű O és $Q$ blokk szerinti nyelvtani szerkezetet már csak a tanulók 10 százaléka (7 fö), a $S$ blokkot pedig csak 6 százaléka (4 fö) érti.

Biztatónak látjuk ugyanakkor azt, hogy az E blokkot teljesítő 70 tanuló 51 százaléka (36 fő), az O blokkot teljesítő 26 tanuló 69 százaléka (18 fö), a Q blokkot teljesítő 14 tanuló 50 százaléka (7 fö), az S blokkot teljesítő 10 tanuló 50 százaléka (5 fő) esetében az adott, tagadást kifejező szerkezet megértése kialakulóban van (lásd 3. 5. és 6. diagram).

Szeretnénk megjegyezni, hogy kutatásunk nem tekinthető reprezentatív kutatásnak. Így eredményeink sem általánosíthatók. Ugyanakkor a kutatási tapasztalataink meggyőznek arról, hogy a TROG-H teszttel történő adatgyűjtést érdemes nagyobb, akár országos mintán is elvégezni. 
A kutatási eredmények értelmezésének korlátjaként tekintünk továbbá néhány további kutatási tapasztalatra. Bár ahogyan azt fent jeleztük, a tesztfelvétel során betartottuk a kézikönyv szerinti eljárásrendet, megfigyeltük, hogy a tanulók megoldását néhány dolog befolyásolhatta. A tesztmondat értelmezését az adatfelvevő például a mondaton belüli hangsúlyok módosításával, illetve a hanglejtéssel segítheti vagy éppen akadályozhatja is. Talán nem mindegy, hogy például a „Fiú nem fut.” mondatban a nem szót hogyan ejtjük: hangsúlyosan vagy nyomaték nélkül. A tesztkönyv erre is ad iránymutatást: a tesztmondatokat tisztán és természetesen kell felolvasni, a kritikus (vizsgált) morfémának enyhe, de nem természetellenes hangsúlyt adva (Lukács \& mtsai, 2011). A vizsgálati helyzetben ezt a szempontot nem könnyű mindvégig megtartani, feltehetöleg ezt egy hanganyag lejátszása tudná csak egységesen biztosítani. Másfelöl a tanulói megoldást befolyásolhatja az is, hogy a tesztmondatot a tesztkönyvben történő lapozás közben (túl gyorsan) vagy a tesztoldal megtekintésére biztosított néhány másodpercet követően (a képi információ feldolgozására kellő időt engedve) mondjuk el; ehhez szintén biztosít támpontot a kézikönyv.

Az értelmileg akadályozott tanulókról tudjuk, hogy a figyelmüket a szokásosnál rövidebb ideig lehet fenntartani. A jelen elemzésben bemutatott $O$ blokkig például 12 blokkot kellett már teljesíteni, azaz 48 mondathoz tartozó képre kellett rámutatni. Így a tévesztések nemcsak a szókincs hiányával és/vagy a grammatikai szerkezet értelmezése körüli nehézségekkel, hanem akár a figyelem kifáradásával is magyarázhatók. Jó példa lehet erre az az eset, amikor a tanuló több egymást követő feladat megoldásakor, a tesztmondatot szinte ki sem várva, a 4 kép közül konzekvensen a mutatáshoz használt kezéhez legközelebb eső, jobb alsó képre mutatott.

A jelen tanulmányban vizsgált tesztmondatoknak a terjedelme is változik. $\mathrm{Az} E$ blokkhoz képest az $\mathrm{O}, \mathrm{Q}$ és $\mathrm{S}$ blokkokban a tesztmondatok egyre több szóból állnak. Így a tévesztést a tesztmondat megjegyzéséhez szükséges munkamemória terjedelme is befolyásolhatja.

\section{KÖVETKEZTETÉSEK ÉS JAVASLATOK}

A kutatási eredmények értelmezésének korlátaira figyelemmel kísérletet teszünk néhány, a kutatási eredmények alapján mégis hasznosnak tűnő tanács megfogalmazására.

1. Javasoljuk az általános iskola legalább alsó tagozatán a tagadást kifejező mondatok használatának kerülését úgy szóban, mint képi vagy írott nyelvi formában, azokban az esetekben, amikor nem kifejezetten a tagadás tanítása a cél. Ha lehetséges, akkor ezek helyett állító mondatokat fogalmazzunk meg.

2. Szükségesnek tünik a tagadószavak és tagadó szerkezetek jelentésének, jelentést módosító hatásának tudatos tanítása, különösen a felső tagozaton. Érdemes a tagadást kifejező egyszerű mondatok felől a tagadást kifejező öszszetett mondatok felé haladni.

a) A tagadó szerkezet megértését a szokásosnál erőteljesebb hangsúlyozással és hanglejtéssel támogassuk. A közléshez további kiegészítő magyarázatot is füzhetünk. Ha van rá lehetőség, akkor szemléltessük is a gondolatunkat. 
b) Feltételezhetjük, hogy amíg az értelmileg akadályozott tanuló a konkrétan felismerhető fogalmakat, cselekvéseket (például kutya, kislány, fiú, illetve ül, ugrik, iszik, fut) könnyebben felismeri, addig a konkrétan nem látható cselekvések (például nem ül, nem ugrik, nem iszik, nem fut - hanem valami mást csinál) megértése bizonytalanabb. Tanítás során a láthatatlan „nem” szó értelmezését nonverbális jelekkel mégis láthatóvá tudjuk tenni. Miközben mondjuk (nyelvi jel) például „A kutya nem ül.” mondatot, a „nem” szó hangoztatása közben fejrázással, és/vagy az ökölbe zárt kézzel, de felfelé mutató mutatóujjunkat jobbra-balra mozgatva (nem szóbeli jel) tudatosan megerősíthetjük a tagadószó jelentését.

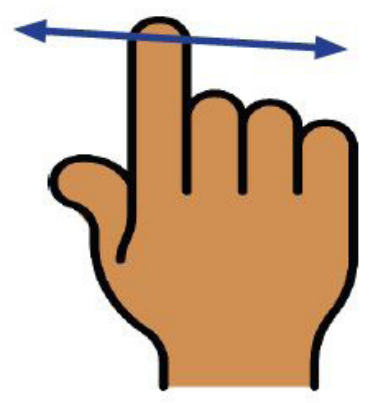

2. sz. kép. A „nem” szó jelentésének megerősitése nonverbális jellel

A kommunikáció 1-8. osztályos kerettantervben az 1-2. osztályos tananyagban, a társadalmi érintkezési formák témán belül, megfigyelhetünk ezzel kapcsolatos példát, amikor a fejlesztési tevékenységek között szerepel a fejrázás mint kommunikációs eszköz. Javasolt lehet azonban további hasonló fejlesztési tevékenységek és fejlesztési célok kidolgozása és beiktatása a kerettantervbe.

\section{Javaslatok az értelmileg akadályozott személyeknek szóló könnyen érthető üzenet készítésének szabály- rendszeréhez}

1. Tiltást kifejező gondolatok helyett inkább arról írjunk, hogy mit kell az olvasónak tennie. Ha mégis alkalmazzuk a tiltást, akkor tegyük mellé azt is, hogy milyen magatartást, cselekvést várunk el a tiltott magatartás, cselekvés helyett. Például „A piros lámpánál ne menj át a zebrán!” helyett „Piros lámpánál állj meg! Várd meg a zöld lámpát! Zöld lámpánál menj át a zebrán!”

2. Lehetőség szerint ne használjunk tagadó szerkezetű, egyszerü mondatokat a könnyen érthető szövegben. Az összetett mondatokban a kifejezett tagadást mindenképpen kerüljük el (például nemcsak..., de...; sem..., sem...). A tagadó szerkezet helyett állításokat fogalmazzunk meg. Ha mégis írunk tagadó szerkezetet, akkor a szöveget képi formában is magyarázzuk meg. Az összetett mondatot bontsuk egyszerủ mondatokra.

Kutatási tapasztalataink alapján fontosnak tartjuk azt is, hogy ne csak az értelmileg akadályozott tanuló felméréskori státuszát (a vizsgálati protokoll betartása 
melletti, beavatkozásmentes aktuális teljesítményét) tudjuk feltárni. Az adatfelvételkor számos olyan pillanatnak voltunk a részesei, amikor úgy éreztük, „egy pici” segítséggel a tanuló másodszorra meg tudta volna oldani a feladatot. Ugyanakkor az ilyen „pici segítségnyújtásra” a tesztfelvételi eljárás nem adott lehetőséget. Akadályt jelenthet továbbá az is, hogy az adott tesztfelvételi protokoll nincs tekintettel az értelmileg akadályozott tanulók figyelmének, munkamemóriájának a jellemzőire. Nincs mód arra sem, hogy a szóbeli közlés helyett például képi úton adjunk utasítást. Meggyőződésünk, hogy a gyógypedagógus gyakorlati munkáját olyan, az értelmileg akadályozott tanuló jellemzőit figyelembe vevő pedagógiai diagnosztikai eszközzel lehetne jól támogatni, amelynek alkalmazásával az értelmileg akadályozott tanuló tanulási folyamatának jellemzőit is fel tudjuk tárni. Ezért egy olyan új, kifejezetten értelmileg akadályozott tanulók felmérését szolgáló kutatási eszköz megalkotásán gondolkodunk, amellyel azt is láthatóvá lehetne tenni, hogy például milyen típusú nonverbális jelekkel lehet elősegíteni a megértést, ezzel a sikerélményt. Az értelmileg akadályozott, 1-8. osztályos tanulók fejlesztésének, tanításának és nevelésének egyes szakaszaiban ezek a többletinformációk talán több gyakorlati ismerethez vezethetnének.

Bízunk abban, hogy ezzel a kutatási beszámolóval hozzájárulhatunk az értelmileg akadályozott tanulók beszédértésének jobb megismeréséhez, illetve a könnyen érthető kommunikációban adekvát és tudományosan bizonyított szabályok kidolgozásához.

\section{KöSZÖNETNYILVÁNÍTÁS}

Szeretnénk köszönetet mondani azoknak az intézményvezetőknek, akik lehetőséget biztosítottak arra, hogy az általuk vezetett intézményekben végezzük az adatfelvételt. Köszönetet mondunk továbbá az egyes intézményekben a kapcsolattartó személyeknek és az osztályfőnököknek, akik az adatfelvételhez szükséges előkészületekben, az adatfelvétel menetének koordinálásában és lebonyolításában nélkülözhetetlen segítséget nyújtottak. Hálásak vagyunk a szülöknek és a tanulóknak az adatfelvételhez való hozzájárulásért és az együttműködésért. Végül köszönjük az anonimizált adatok rögzítéséhez és az elemzéshez nyújtott segítséget a statisztikusnak.

\section{Irodalom}

Babarczy A., Lukács Á. \& Pléh Cs. (2015). 10. A nyelvelsajátítás elméleti modelljei. In Pléh Cs. \& Lukács Á. (szerk.) (2015). Pszicholingvisztika. Akadémiai Kiadó. Budapest.

Bishop, D. V. M. (1983): Test for the Reception of Grammar. OS Hungary, Budapest.

Csákvári, J. (szerk.) (2006). Ajánlások értelmileg akadályozott gyermekek, tanulók kompetencia alapú fejlesztéséhez: Szociális, életviteli és környezeti kompetenciák. suliNova Kht., Budapest.

Hegedüs H. (2020). A kevesebb néha több. Fogyatékosság és Társadalom 2020.1:63-73. https://doi.org/10.31287/FT.hu.2020.1.7

Horváth P. L. (2020c). A könnyen érthetö kommunikációs képzési programok képzésfejlesztésének története Magyarországon a fogyatékossággal élő személyek jogairól szóló ENSZ egyezmény tükrében. (Doktori értekezés.) Eszterházy Károly Egyetem, Eger.

Horváth P. L. (2020a). Mit jut eszébe erröl a szóról: fogyatékosság? Carissimi, 11.1:13-15.

Horváth P. L. (2020b). Mi jut eszébe erről a szóról: fogyatékosság? II. Carissimi, 11.2:9-10. 
Inclusion Europe \& ÉFOÉSZ (2009). Információt mindenkinek! A könnyen érthető kommunikáció európai alapelvei. Inclusion Europe - ÉFOÉSZ, Brüsszel - Budapest.

Irányelvek a sajátos nevelési igényű tanulók iskolai oktatásához (2020). https://www.oktatas.hu/ pub bin/dload/kozoktatas/kerettanterv/SNI iranyelvek.docx Letöltés ideje: 2020.12.21.

Keszler B. \& Lengyel K. (2019). Kis magyar grammatika. Akadémiai Kiadó. Budapest. https://doi. org/10.1556/9789630599641

Kocsisné Kálló V., Túriné Gál A. \& Ruzsics I. (2013). Kommunikáció fejlődése és fejlesztése értelmileg akadályozott személyeknél. http://www.jgypk.hu/mentorhalo/tananyag/Kommunikci_fejldse_s_fejlesztse_rtelmileg_akadlyozott_szemlyeknl/index.html Letöltés ideje: $2020.12 .2 \overline{2}$.

Kommunikáció - kerettanterv a középsúlyos értelmi fogyatékos tanulók számára 1-8. évfolyam. 2020 https://www.oktatas.hu/pub_bin/dload/kozoktatas/kerettanterv/ksni_1_8/Kommunikacio.doc Letöltés ideje: 2020.12.22.

Lukács Á. \& Kas B. (2014). Nyelvelsajátítás és értelmi fogyatékosság. In Pléh Cs. \& Lukács Á. (szerk.), Pszicholingvisztika 2. Akadémiai Kiadó, Budapest. 1383-1403.

Lukács Á., Győri M. \& Rózsa S. (2011). TROG Kézikönyv. OS Hungary, Budapest.

Lukács Á., Győri M. \& Rózsa S. (2013). TROG-H: új sztenderdizált módszer a nyelvtani megértés fejlődésének vizsgálatára. Gyógypedagógiai Szemle, 41.1:1-22.

Lukács Á., Pléh Cs. \& Racsmány M. (2008). Szabályos és kivételes morfológia Williams-szindrómában. In Gervain J. \& Pléh Cs. (szerk.), A láthatatlan nyelv. Gondolat, Budapest.

Olvasás-írás kerettanterv a középsúlyosan értelmi fogyatékos tanulók számára 1-8. évfolyam (2020). https://www.oktatas.hu/pub_bin/dload/kozoktatas/kerettanterv/ksni_1_8/Olvasas-iras.doc Letöltés ideje: 2020.12.20.

Radványi K. - Pléh Cs. (2002): Középsúlyos értelmi fogyatékos, iskoláskorú gyermekek beszédének néhány nyelvtani jellemzője. Pszichológia, 22.3:245-254.

Radványi K. (2005). Kromoszóma-rendellenesség miatt fejlődési elmaradást mutató Down-szindrómás személyek nyelvi képességeinek vizsgálata. In Gervain J., Kovács K., Lukács Á. \& Racsmány M.: Az ezerarcú elme. Tanulmányok Pléh Csaba 60. születésnapjára. Akadémiai Kiadó, Budapest. 88-101.

Sápiné Bényei R. (2020). Magyar nyelv 5. NAT2020. Oktatási Hivatal, Budapest. https://www. nkp.hu/tankonyv/magyar_nyelv_5_nat2020/Letöltés ideje: 2021.03.01.

Az értelmileg akadályozott tanulók általános iskolai oktatását a kerettantervekben szereplő fogalmak könnyen érthető képi magyarázatával támogatjuk. Az alsó tagozatos kerettantervek alapján eddig 550 db kép készült el. A képek megrajzolásakor törekedtünk a személyállandóságra. A KÉK Család tagjai az összes, személyeket ábrázoló képen visszaköszönnek.

Partnereink a fejlesztésben: Csalogány EGYMI, Budapest és Kozmutza Flóra EGYMI, Hódmezőváráshely, valamint az SZTE JGYPK gyógypedagógia alapképzési szak hallgatói. További információkért kövesse a projekt facebook oldalát, vagy olvassa el a képtár bemutatásáról szóló híreket.

\section{A KÉK Család tagjai}

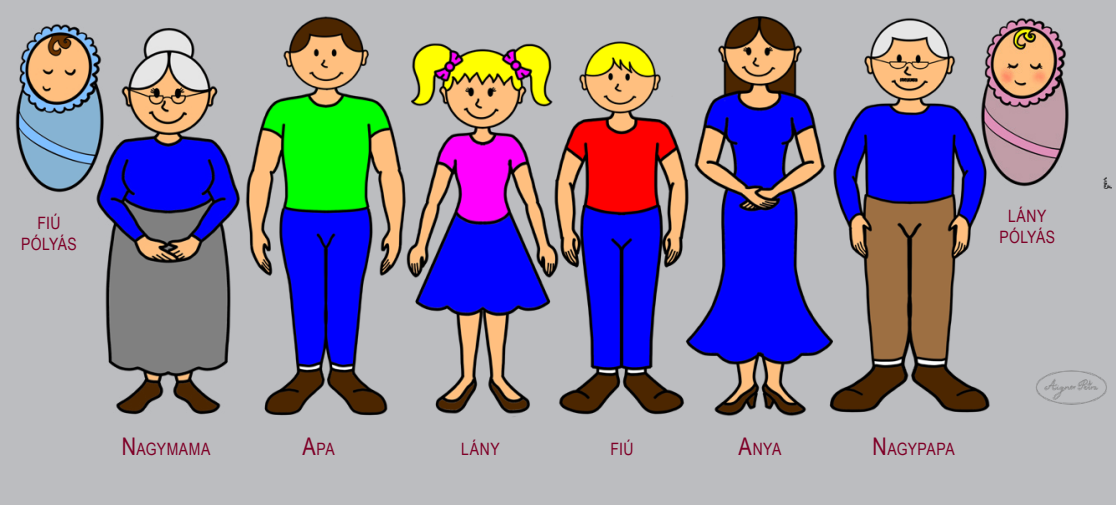




\section{A könnyen érthető kommuni- káció és a Hublow olvasástaní- tási módszer kapcsolata - egy esetismertetés tükrében}

Jelen tanulmány a könnyen érthető kommunikációt kapcsolja össze a Hublow olvasástanítási módszerrel. Az elméleti részben megvizsgáltam, hogy mit mondanak az olvasás tanításáról a központi pedagógiai dokumentumok (Irányelvek, kerettanterv), mennyire segítik vagy gátolják az olvasás tágabb értelmezését.

Továbbá a két módszer részletes bemutatásán túl igyekeztem megfejteni, hogy mi a gond azokkal a szövegekkel, melyekkel a hétköznapi életben találkozunk, miért nehéz ezeknek a megértése az értelmi sérült személyek számára. Megvizsgáltam több nyelvi szintezési rendszert, ezekben kerestem az olvasás tágabb értelmezésének lehetőségét. Az elméletalkotást alátámasztom a gyakorlati tapasztalataim részletes leírásával, melyet értelmileg akadályozott gyermekek tanítása során szereztem a Hublow olvasástanítási módszert alkalmazva.

Kulcsszavak: könnyen érthető kommunikáció, Hublow módszer, nyelvi szintek, esettanulmány, olvasástanitás

\section{BEVEZETÉs}

Tanulmányomban betekintést adok a könnyen érthető kommunikáció módszerébe és a Hublow olvasástanítási technikába, valamint röviden bemutatom ennek a két módszernek a kapcsolatát. A könnyen érthető kommunikáció alkalmazása még nagyon kezdetleges a hazai gyógypedagógiában; a Hublow olvasástanítási módszert pedig tapasztalataim alapján nagyon kevesen ismerik, és még ennél is kevesebben használják. Az esettanulmányi rész a saját tapasztalatomról szól, melyet a Hublow-módszer kétéves alkalmazása során szereztem. Ezzel szeretném érzékeltetni, hogy milyen felszabadult örömet okozhat a gyermekeknek, ha a képességeikhez igazodó módszerrel oktatjuk őket. Mennyivel több a sikerélményük így, és ezáltal a motivációjuk is, ami pozitív hatással van a velük foglalkozó szakemberekre is. A legfontosabb célom annak a bemutatása, hogy az információhoz való hozzáférés fontos mindenkinek. A tanulmány egésze azt próbálja bemutatni, hogy milyen ajtókat tárhatunk ki az értelmi sérült személyek előtt az akadálymentes kommunikáción keresztül.

\section{AZ ÉRTELMI SÉRÜLT SZEMÉLYEK ALAPVETŐ JOGAI}

Ebben a fejezetben bemutatom azokat a legfontosabb jogi vonatkozásokat, melyek - többek között - az értelmi sérült személyek számára az információhoz való hozzáférhetőséget hivatottak biztosítani.

1993-ban az ENSZ közgyülése elfogadta a fogyatékossággal élő emberek esélyegyenlőségének alapvető szabályai című határozatát, melynek $5 \mathrm{~b}$ szabálya az információ és kommunikáció hozzáférhetőségéről szól. Ebben a dokumentumban 
olvasható, hogy a tagállamoknak biztosítaniuk kell a szóbeli információhoz való hozzáférést, többek között a „felfogásbeli nehézségekkel élőknek” is. A diagnózisról, a jogokról, az elérhető szolgáltatásokról és programokról szóló információkat olyan formában kell a nyilvánosságra hozni, hogy a fogyatékos emberek is hozzáférhessenek. Kiemeli, hogy a siket és a vak embereken túl az egyéb kommunikációs nehézségekkel élők szükségleteit is figyelembe kell venni. Továbbá a médiát arra készteti, hogy tegyék hozzáférhetővé szolgáltatásaikat a fogyatékos személyek számára (A fogyatékossággal élő emberek esélyegyenlőségének alapvető szabályai, 1993).

A magyarországi 1998. évi XXVI. törvény, mely a fogyatékos személyek jogairól és esélyegyenlőségük biztosításáról szól, már rendelkezik, arról, hogy mely esetben válik egyenlő eséllyel hozzáférhetővé az információ a mentális és kommunikációs funkciókban sérült emberek számára. Továbbá a fogyatékos személyeket megillető jogokban kiemelt szerep jut a kommunikációnak, föképpen a közszolgáltatások igénybevétele kapcsán. „A kommunikációban jelentősen gátolt személy számára a közszolgáltatások igénybevételekor lehetővé kell tenni a tájékozódás és a személyi segítés feltételeit." E kritérium tényleges megvalósulása vezethetne el minket oda, hogy mindenki valóban szerves tagja lehessen a társadalomnak (Fot.).

Az ENSZ 2006-ban elfogadta a Fogyatékossággal élő személyek jogairól szóló egyezményét és az ahhoz kapcsolódó Fakultatív jegyzőkönyvet, melyet Magyarország az elsők között írt alá 2007-ben, és még ebben az évben a XCII. törvénnyel ratifikálta is. Az egyezmény 9. cikke foglalkozik a hozzáférhetőség kérdésével: ebben a cikkben a fizikai környezeten és a közlekedésen túl szó van az információhoz és kommunikációhoz való hozzáférésről is. Ezen belül például az elektronikus szolgáltatásoknak és a segélyhívó rendszereknek is alkalmazkodniuk kell a célcsoport igényeihez. A 21. cikk a véleménynyilvánításról és a szólás szabadságáról, valamint az információhoz való hozzáférésről szól. Eszerint „,a részes államok minden szükséges intézkedést megtesznek annak biztosítására, hogy a fogyatékossággal élő személyek másokkal azonos alapon, az általuk megválasztott kommunikációs formán keresztül gyakorolhassák a szólásszabadság és a véleménynyilvánítás szabadságának jogát". Ez a kommunikációs forma lehet akár jelnyelv, Braille-írás, augmentatív és alternatív kommunikáció, vagy bármilyen, a fogyatékos személy által választott kommunikációs módozat (fogyatékosságügyi ENSZ egyezmény, 2006).

\section{Az információ hatalom!}

Az információk, amelyeket megértünk, nagyon fontos szerepet játszanak az életünkben, hiszen segítenek nekünk abban, hogy megfelelő döntéseket tudjunk hozni. Ez az önrendelkezésünk alapja, legyen szó akár egy termék kiválasztásáról a boltban, vagy a bankszámlacsomagunk adatainak ismeretéröl. Különböző jelentőségű dolgok ezek, mégis ugyanarra van szükségünk hozzájuk: számunkra érthető információra (Horváth, 2017b). „Ha valamit nem értek, lehet, hogy nem bennem van a hiba, hanem a szöveg alkotójának kellene jobban alkalmazkodnia a felhasználók képességeihez" (Horváth, 2017b:9).

Az információkhoz szeretnének hozzáférni az értelmi sérült emberek is, méghozzá egyenlő eséllyel. Minél több számára érthető információhoz hozzáfér egy személy, annál inkább a saját kezébe veheti az élete irányítását. Tehát, ha a fenti idézetet tartjuk szem előtt, akkor az értelmi sérült személyek igényeihez alkal- 
mazkodva, számukra könnyen érthető információkat hozhatunk létre. Tudományos kutatások igazolják, hogy a célcsoport ezekből az információkból többet ért meg, mint ugyanazon szövegek sztenderd változatából (Sutherland \& Isherwood, 2016; Chinn \& Homeyard, 2017). Az információk egyenlő esélyű hozzáférésének színtere elsősorban a média, a világháló és a különböző ügyintézési helyszínek, mert itt szerzünk információkat a leggyakrabban. Nagyon fontos első lépés lehetne, ha a jelnyelvhez és a Braille-íráshoz hasonlóan ismertté és alkalmazottá válna a könnyen érthető kommunikáció, mely az értelmi sérült személyek tájékozódását segíti (Horváth, 2017b). „Nem az értelmi sérült emberek képtelenek hát az öket körülvevő világ értelmezésére, hanem nekünk van dolgunk az információk könnyen értelmezhetővé tételével" (Horváth, 2017b:10).

\section{AZ ÉRTELMI SÉRÜLT TANULÓK INFORMÁCIÓ- FELDOLGOZÁSÁRÓL}

Az egyén társadalmi integrációjához fontos, hogy elsajátítsa az olvasás, írás és számolás készségét. A szülők részéről gyakran fogalmazódik meg az igény, hogy értelmileg akadályozott gyermeküket mihamarabb tanítsuk meg olvasni, hiszen az iskola feladata, hogy a gyermek alkalmazni tudja az alapvető kultúrtechnikákat. Ehhez azonban a gyermekeknek - hosszabb előkészítő szakasz beiktatásával - el kell sajátítaniuk bizonyos készségeket. Fontos még, hogy az egyes tanulási folyamatokat kis lépésekre kell bontani számukra, valamint kiemelt jelentősége van a cselekvésbe ágyazott tevékenységeknek (Mede, 2010).

„Jellemző jegyeik az olvasás, az írott szöveg megértése területén

- alacsony nyelvi és fogalmi szint, halmozott beszédhibák

- az analizáló-szintetizáló képesség alacsony szintje

- nehezített az akusztikus és a vizuális észlelő és megkülönböztető képesség

- a beszédszervek hangösszevonást nehezítő összerendezetlensége

- téri orientációs zavarok

- a finommozgások éretlensége, a vizuomotoros koordináció zavara

- a verbális igénytelenség, a motivációs bázis szűk volta" (Szabó, 2006:29).

Ez a leírás erősen medikális szemléletü, hiszen az ép fejlődésmenethez viszonyít, illetve minden jelző negatív benne. Ez azért nehezítheti a fejlesztést, mert a hiányosságokra nem lehet teljes értékű pedagógiai tervező munkát építeni. Inkább arra lenne szükség, hogy azt tudjuk meg, mire képesek a gyermekek. Másfelől ezek a negatív minősítések erősítik a társadalmi előítéleteket, bántók lehetnek mind az érintett személyek, mind pedig a szüleik számára. A jelenleg hozzáférhető szakirodalmi források között nehéz ettöl eltérő megközelítést találni.

Tapasztaljuk azonban, hogy az olvasás tanulása szempontjából nagyon különbözőek az értelmileg akadályozott gyermekek. A jelenleg alkalmazott analitikus-szintetikus olvasástanítási módszerrel a gyermekek kisebb hányada sajátítja el az olvasást készségszinten (Szabó, 2006). Vannak azért, akik képesek rá, és szerintem ezt fontos szem előtt tartani. Az én elképzelésem egy olyan rendszer, ahol minden értelmileg akadályozott gyermek lehetöséget kap arra, hogy megismerkedjen a hangokkal és a hozzájuk tartozó betűkkel, elsajátíthatja az összeolvasást, az olvasott szavak, mondatok értelmezését. Azonban, ha ez a módszer nem hoz eredményt, nincs siker- 
élménye a gyermeknek, akkor szükség lenne az olvasás fogalmának tágabb értelmezésére. A fontos az, hogy a tanulók az őket körülvevő információt megértsék. Információt azonban nem csak a betűk, szavak, mondatok hordoznak, hanem például képek, piktogramok és ábrák is. Ezt a megközelítést alkalmazza a Hublow-rendszer, melyet a későbbiekben fogok ismertetni. Úgy képzelem el a váltást az olvasástanítást illetően a fent említett esetben, mint a 20. század második felében az értelmileg akadályozott tanulók számára létrehozott $A-B$ tagozatok esetében, amikor a középső szakasz után két tagozatra bontották az osztályokat. Az „A” tagozaton tanultak tovább azok a gyermekek, akik megfelelő mértékben el tudták sajátítani a kultúrtechnikák alapjait. A „B” tagozaton pedig igyekeztek az addig megszerzett ismereteket megtartani a gyermekeknél a kultúrtechnikai tantárgyakból.

Először áttekintem, hogy mit mondanak az olvasás tanításáról a pedagógiai tartalmakat központilag szabályozó dokumentumok (irányelvek, kerettantervek).

A 2012-es és a 2020-as Nemzeti Alaptanterv határozza meg jelenleg Magyarországon a sajátos nevelési igényű tanulók oktatásának kiindulópontjait. Erre épülve készültek el a sajátos nevelési igényű gyermekek, tanulók óvodai nevelésének, iskolai oktatásának irányelvei. Ezek a dokumentumok külön csoportként említik a középsúlyosan értelmi fogyatékos-gyermekeket, tanulókat.

A sajátos nevelési igényű tanulók iskolai oktatásának irányelvei 2020-ban megújultak (Irányelvek, 2020). Azért tartom mégis fontosnak megemlíteni a 2005-ben hatályba lépő, felmenő rendszerben kivezetésre kerülő régi irányelvet (OM rendelet, 2005), mert az esettanulmány fejezetben ismertetett tapasztalatom fontos szegmense, hogy 2011-2013 között ez az irányelv volt érvényben.

A 2005-ben hatályba lépő régi irányelvben az olvasás javasolt témakörei között szerepeltek többek között a téri orientációs gyakorlatok, az emlékezet-, gondolkodás- és figyelemfejlesztés. A fejlesztési feladatok között szintén megjelent a figyelem és az emlékezet fejlesztése, a térbeli viszonyok gyakorlása, valamint az észlelés fejlesztése (OM rendelet, 2005).

Felmerült bennem a kérdés, hogy csak a betűkből szintetizálva összeolvasott szavak, mondatok olvasására képes gyermekek teljesíthetik a felsorolt feladatokat? Véleményem szerint nem. Ugyanezen képességek kialakulása szükséges például sorozatképeket olvasni tudó gyermek számára is. Példának hozok négy képességet, amire mind a két esetben szükség van: észlelés, figyelem, emlékezet, téri tájékozódás. Akár egy képsorozatot, akár szavakat, mondatokat akarunk elolvasni, szükséges, hogy megfelelöen észleljük azt. Meg kell tudni figyelni az esetleges változásokat. Kell, hogy emlékezzünk, mit olvastunk a mondat elején, vagy arra, hogy a képsorozat elején milyen kép volt. Szükséges, hogy tudjuk, balról jobbra olvasunk szavakat és képsorozatokat egyaránt.

A 2020 szeptemberétől felmenő rendszerben bevezetésre kerülő sajátos nevelési igényü tanulók iskolai oktatásának irányelvében az egyes tanulási területekhez ajánlások jelennek meg. A magyar nyelv és irodalom tanulási terület speciális feladatait az olvasás témakörén belül is megfogalmazza a dokumentum (Irányelvek, 2020).

Ebből szeretném kiemelni meglátásom szerint a tanulmány szempontjából legfontosabb részt:

„A szövegértő olvasás nehezített kialakulása esetén a megelőző olvasási szintek gyakorlása, egyéni képességekhez igazodó választással:

- szituációelemzés, anticipációs (várható esemény felismerése, például terítés $\rightarrow$ étkezés) képesség, 
- tárgyi szimbólum értelmezése (például fakanál = tankonyhai foglalkozás),

- képi szimbólumok (fénykép, valósághű vagy egyszerüsített ábra),

- piktogramok, logók értelmezése,

- állandó feliratok, szignálszavak, globális szófelismerés (például WC, KIJÁRAT, MOZI)" (Irányelvek, 2020:66).

Az itt leírtak nagyon fontos változást hoznak a korábbi, még 2005-ben hatályba lépő régi Irányelvekhez képest. Az idézett bekezdés az olvasás tágabb értelmezésére ad lehetőséget, és mindezt az értelmi akadályozott tanulók oktatásába is beemeli. Nem konkretizálja az olvasástanítást a betűk, szavak, mondatok olvasására.

A kerettanterv tovább pontosítja a pedagógus lehetőségeit. Itt már konkrétan az írott nyelv használatáról van szó. Bár pozitívum, hogy megemlíti mellette a képes, szimbólumos információforrások közötti eligazodás fontosságát is.

„A tanulóval szemben támasztott elvárás, hogy folyamatosan legyen képes megismerni az olvasott és írott betűk, szavak, egyszerủ mondatok jelentéstartalmát, váljon igénnyé az egyszerü írásos utasítások, figyelmeztetések, feliratok értelmezése, alakuljon ki a tevékenységek és információk piktogramos megjelenítésének értelmezési képessége, folyamatosan bővüljön a környezetben előforduló írásos utasítások megértése, követése" (olvasás-írás kerettanterv 1-8. osztály, 2020:1).

A kerettanterv szakaszonként már konkrét feladatokat határoz meg a gyógypedagógus számára. Leírja, hogy melyik évfolyamon, milyen órakeretben mi a fejlesztési cél, és az milyen feladatok elvégzésével érhető el (ideális esetben). Itt fejlesztési célként jelöli meg a betűtanítást, tehát a kerettanterv - értelmezésem szerint már nem ad lehetőséget az olvasástanítás tágabb értelmezésére. De miért kell minden gyermek számára megjelölni célként a betűolvasást? Hiszen az értékelés is reálisabb és egyéni lenne, ha például a képek, később képsorozatok, majd elvont piktogramok olvasása is megjelenhetne célként. Az értelmileg akadályozott tanulók körében álláspontom szerint értelmezhetetlen ötfokozatú értékelés helyett megjelenhetne a szöveges értékelés, melyből a szülők is reálisabb képet kaphatnának arról, hogy gyermekük miként teljesít az olvasás területén.

\section{A BAJ A SZTENDERD SZÖVEGEKKEL?}

Az információ folyamatosan áramlik felénk, több csatornán keresztül is. Van, amire szükségünk van, és mi magunk keressük meg, van, ami kéretlenül talál ránk. A tanulmány témájából adódóan én most csak az írott szövegekkel foglalkozom, azok nehezen érthetöségének okait igyekszem összesíteni. Sokféle szöveggel találkozunk a mindennapi életünk során, ezért nem lehet általánosságban beszélni róluk. Példákon keresztül igyekszem bemutatni, hogy melyek azok a jellemzők, amik megnehezítik egy szöveg értelmezését.

Ha a boltban bármilyen terméket leemelünk a polcról, hogy megnézzük az öszszetevőit, a legelső, ami szembetűnik, hogy nagyon apró betűvel írták a dobozra az információt. Ráadásul nem csak az összetevőket találjuk meg a dobozon, hanem a gyártási, tárolási leírásokat is: ez tovább nehezíti az értelmezést. Sok szövegböl kell kiválasztanunk a számunkra szükséges információt. Ha meg is találtuk, amire szükségünk van, a szöveg sokszor bonyolult kifejezésekkel, rövidítésekkel van tele. 
(Elektronikus) postaládánkba akár minden héten érkezhet csekk; a szolgáltató egy levelet is mellékelni szokott hozzá. Ebben hosszú, összetett mondatokban fejtik ki, hogy mi a következménye, ha nem fizetjük be a tartozásunkat. Sokszor nehezen átlátható táblázatokban részletezik a fogyasztásunkat: ezek tele vannak nagy számokkal, nehezen értelmezhető százalékértékekkel.

Mindezek mellett a számítástechnikának köszönhetöen ma már formai szempontból igen változatosan lehet megszerkeszteni egy adott szöveget. Vannak olyan betűtípusok, melyeknek az olvasása nagy odafigyelést igényel bárki részéről. Sokszor egy-egy újság olvasásánál is nagyon figyelni kell a sok hasáb és tördelés miatt, hogy tudjuk, hol folytatódik a szöveg. Rengeteg kép (akár oda nem illő kép) és színhasználat jellemzi a hirdetéseket, amik nagyban megnehezíthetik az eligazodást egy írásban.

Az eddig felsorolt jellemzők egy átlagos intellektusú személy tájékozódását esetleg megnehezítik, de az értelmi sérült személyek információhoz való hozzájutását akár el is lehetetleníthetik. Pedig ezek a mindennapokban előforduló helyzetek lehetnek. Ha egy hivatalos szervtől kapunk levelet és az számos nehezebben érthető jogi kifejezést tartalmaz, rögtön megtapasztaljuk azt az elveszettség-érzést, amit egy sérült személy oly sokszor átél.

\section{KÖNNYEN ÉRTHETŐ KOMMUNIKÁCIÓ}

\section{Célja, célcsoportjai}

Minden embernek joga van ahhoz, hogy a társadalom müködésében aktívan közremüködjön. Ezt azonban csak akkor lehet megvalósítani, ha a megfelelő információk minden személy számára érthetőek, hiszen ekkor tudnak a személyek egyénenként megfelelő döntést hozni. Ennek érdekében olyan kommunikációs módszerek alkalmazása szükséges, amelyek minden ember számára biztosítják a megértést és a kifejezést is, alkalmazkodnak az egyéni igényekhez (Farkasné \& Graf-Jaksa, 2009).

Ezt a fajta infokommunikációs akadálymentesítést a könnyen érthetö kommunikáció módszerével érhetjük el. A célcsoport számára segítséget nyújt abban, hogy hozzáférjenek a szükséges információkhoz, ez alapján megfelelö döntést tudjanak hozni, és ebböl kifolyólag önálló, másoktól független életet tudjanak élni (Horváth, 2017a).

A könnyen érthető kommunikáció megoldást nyújt a megértési nehézségekkel élő emberek számára, akik támogatást igényelnek az olvasáshoz, íráshoz vagy az információ értelmezéséhez. Másképpen fogalmazva közéjük tartoznak az értelmi sérült személyek, a siket személyek, a környezetüktöl eltérő anyanyelvű emberek, a szociálisan hátrányos helyzetű egyének, kevéssé iskolázott személyek, a kiskorú gyerekek és az idős emberek (Farkasné \& Graf-Jaksa, 2009).

\section{Módszere}

A könnyen érthető kommunikáció módszerének ismertetéséhez négy útmutatót tanulmányoztam át. Ezek a következők: 
1. Információ mindenkinek - A könnyen érthető kommunikáció európai alapelvei (Inclusion Europe \& ÉFOÉSZ, 2009a)

2. Ne írjon nekünk, nélkülünk! - Hogyan vonjunk be értelmi fogyatékossággal élő embereket könnyen érthető szövegek készítésébe? (Inclusion Europe \& ÉFOÉSZ, 2009b)

3. Hogyan készítsünk könnyen érthető segédanyagot? - Irányelvek (Gruiz, é.n.)

4. Egyszerüen, érthetően - Útmutató könnyen érthető tájékoztatók készítéséhez (Csató, 2002)

Ezen kiadványok átolvasása során szembetűnő volt, hogy nincs egységes szemlélet. Összességében minden dokumentum igyekszik ugyanazokat a szempontokat ismertetni, de kevésbé rendszerezettek a tartalmaik, meglátásom szerint kevésbé logikus a felépítésük. Több útmutató lépésről lépésre leírja, hogyan kell elkészíteni egy könnyen érthető szöveget, de nem ugyanazokat a szakaszokat tartalmazzák, és nem is ugyanabban a sorrendben. A négy írás alapján nem lehet a könnyen érthető szövegekre vonatkozó általános jellemzőket megállapítani. Ami a legszembetűnőbb, hogy következetlenül használták az alapelv és irányelv kifejezéseket, akár egy dokumentumon belül is, de a kiadványokat egymással összehasonlítva is megfigyelhető ez az eltérés. Az általam közölt módszerleírásban igyekszem tisztázni ezen fogalmakat is, illetve a számomra logikus felépítésben írom le a könnyen érthető kommunikáció módszerének alkalmazását.

A könnyen érthető kiadványok készítése során figyelembe kell venni azokat az alapelveket, amelyeket minden körülmények között betartunk. Legfontosabb a bevonás elve, vagyis soha ne írjunk könnyen érthető szöveget értelmi sérült ember közremüködése nélkül. Elöször is kérdezzük meg a célcsoportot arról, hogy miröl szeretne olvasni. Legjobb, ha a szöveg készítésébe is be tudunk vonni értelmi sérült személyeket. Ha erre nincs lehetőség, akkor az elkészült írást feltétlenül mutassuk meg „anyanyelvi lektornak”, majd a javaslatai alapján javított szöveget ismét mutassuk meg neki. A könnyen érthető üzenet készítésében közreműködő, az érthetőséget ellenőrző értelmi sérült személyeknek Magyarországon jelenleg nincs felkészítő képzésük, a célcsoport bármely tagja a segítségünkre lehet ebben a feladatban. Alapelv még, hogy a könnyen érthető kommunikáció Európában elfogadott logója csak akkor kerülhet fel egy kiadványra, ha azt értelmi sérült személy ellenőrizte (Horváth, 2017b).

A könnyen érthető kommunikáció irányelvei a szöveg érthetőségére vonatkoznak, a szavakra és a mondatokra. Ezeket a módszer alkalmazása során irányként kell követni, de a célcsoport szükségletei alapján el lehet tölük térni.

1. Könnyen érthető, közismert szavakat használjunk.

2. Kerüljük a bonyolult kifejezések, az idegen nyelvü szavak, a mozaikszavak használatát.

3. Hasonlatok helyett konkrétan nevezzük meg a dolgokat.

4. A szöveg egészében ugyan azokra a dolgokra mindig ugyanazt a kifejezést használjuk.

5. Fontos a rövid, egyszerü mondatok használata.

6. Kerüljük az összetett mondatok használatát.

7. Ha lehet, akkor ne használjunk tagadást, tiltást (Horváth, 2017b).

8. Kerüljük a százalékos kifejezések és a nagy számok használatát, helyette használjuk inkább a kevés vagy sok szavakat. 
9. Közvetlen legyen a szöveg hangneme, ezt elérhetjük a te vagy ti szavak használatával (Inclusion Europe \& ÉFOÉSZ, 2009a).

A könnyen érthető szövegek formai megjelenésének szabályait az útmutató tartalmazza, ezek általában változtatás nélkül alkalmazhatóak (Horváth, 2017b). Ezeket a formai szabályokat egyre bővülő egységenként csoportosítva mutatom be, az általam logikusabbnak tűnő rendbe téve, az Inclusion Europe - ÉFOÉSZ: Információ mindenkinek - A könnyen érthető kommunikáció európai alapelvei címü kiadvány felhasználásával (Inclusion Europe \& ÉFOÉSZ, 2009a).

1. Betü

1.1. Ne használjunk betűtalpas betűt, mert azoknak az alakja nem egészen letisztult. Az ajánlott betütípus az Arial vagy a Tahoma. Egy szövegben egyféle betütípus jelenjen meg.

1.2. Egyszerủ betűt használjunk, tehát ne legyen dőlt vagy árnyékolt. Ha mégis alkalmazni szeretnénk kiemelést, akkor félkövér legyen a betü, és egy szövegben egyfélét használjunk.

1.3. Nagyobb betüméretet válasszunk, mint 12-es; az ajánlott 14-es.

1.4. Kisbetűket használjunk, ne írjunk teljes szavakat nagybetűvel.

1.5. Kerüljük a színek használatát, legjobb a fekete betű fehér háttéren. Ha mégsem ezt választjuk, akkor az a fontos, hogy kontrasztos legyen.

2. Számok

2.1. Ne írjuk ki betűvel a számokat, mindig arab számmal szerepeljenek a szövegben.

2.2. A dátumokat viszont mindig írjuk ki teljesen, ne rövidítsük őket.

3. Írásjelek

3.1. Minél kevesebb írásjelet használjunk, ha lehet, csak pontot és vesszőt, esetleg kérdőjelet.

3.2. Ha lehet, ne használjuk a speciális írásjeleket, például: \&, :, \# stb.

3.3. Felsorolásnál pontozás használata ajánlott, mert a vesszővel elválasztott felsorolás nehezebben érthető.

4. Szavak

4.1. Kerüljük a szavak elválasztását, mert nehezíti a megértést.

4.2. A betük távolsága legyen normál és végig egyforma, ne használjunk sürített térközt.

5. Mondat

5.1. Minden új mondatot új sorban kezdjünk.

5.2. Egy mondat legyen egy sor, de ha ez nem lehetséges, akkor a vesszőnél válasszuk el, ami a vessző után van, az kerüljön új sorba.

6. Bekezdés

6.1. A bekezdés legyen balra zárt, ne használjuk a sorkizárást vagy a jobbra zárást.

6.2. Ne használjunk behúzást vagy hasábozást a szövegben.

6.3. Hagyjunk ki sort a bekezdések között.

7. Oldal

7.1. Ne legyen egy oldalon túl sok a szöveg.

7.2. Használjuk az alap margóbeállítást.

7.3. Kerüljük a lábjegyzet használatát, inkább írjuk bele a szövegbe az információt. 
8. Teljes kiadvány

8.1. 20-30 oldalnál ne legyen hosszabb egy kiadvány.

8.2. Segíti az eligazodást a kiadványban, ha használunk oldalszámozást.

8.3. Soha ne használjunk képet vagy mintát háttérnek, mert az megnehezíti az olvasást.

8.4. Olyan formátumban dolgozzunk, amit könnyü kezelni az olvasás és a sokszorosítás folyamán, tehát $A 4$-es vagy $A 5$-ös papírméretet válaszszunk.

\section{A Hublow-MódSZER}

\section{A módszer bemutatása}

Christoph Hublow német nyelvű szaklapokban már 1977-től jelentetett meg írásokat az értelmileg akadályozott személyek olvasástanításával kapcsolatban. Elmélete szerint az olvasás fogalmát tágabb értelemben érdemes vizsgálni. Kiterjeszti az olvasástanítást a képek, képsorok, vizuális jelek megértésére is. Azon értelmileg akadályozott gyermekeknél, akik nem tudnak betüt olvasni, az elöbb említett vizuális jelek megértésének közvetlen használati értéke van (Mede, 2010).

„Nincs küzdelem az elvont olvasástechnika elsajátításáért, hanem az értelmes tartalom tudatos keresése a feladatunk a tanuló közvetlen és tágabb környezetéböl” (Pál-Horváth, 2002:3). Ezt a gondolatot azért emeltem ki szó szerint, mert szerintem jól kifejezi a módszer lényegét. „Nincs küzdelem”, mert a tanulóknak és a pedagógusnak is könnyebb, ha olyan dolgot tanulnak és tanítanak, ami kézzelfogható, „értelmes tartalom”, és a gyermeknek a jövőben használható tudást ad, hiszen az ő „közvetlen és tágabb környezetéből” választhatjuk ki a tananyagot. Mind a két félnek nagyobb a motivációja, ha sikerélményekkel teli a nevelési-oktatási folyamat.

\section{A módszer szintjei}

Hublow rendszerében hat szintet különböztetünk meg, melyek módszertani fokozatként jelennek meg az értelmileg akadályozott személyek olvasástanítása során. Az elvonatkoztatás fokának megfelelően alakul ki a sorrend, ezen belül a szinteknek nincs határa, de szigorúan egymásra épülnek (Pál-Horváth, 2002).

1. Szituációk olvasása

„A jelentéshordozók a cselekvő személyek, akik mimikával, gesztusokkal, cselekvésekkel fejezik ki magukat, valamint mozgó és álló tárgyak ismert, közérthető helyzetekben" (Pál-Horváth, 2002:3). Ide tartoznak például az arckifejezések, illetve személyek, tárgyak bizonyos helyzetekben történő értelmezése, ezek összekapcsolása élményekkel, emlékekkel, és így a jelentés felismerése (Pál-Horváth, 2002).

2. Képek olvasása

„A jelentéshordozók konkrét személy, szituáció vagy tárgyábrázolások egyes képeken, képsorokon" (Pál-Horváth, 2002:3). Például rajzok, festmények, fényképek ismert tárgyakról és személyekről, képsorok, képeskönyvek. A ké- 
peket olvasó személy felismeri a képet vagy annak egy részletét, majd összekapcsolja a saját élményeivel, emlékeivel (Pál-Horváth, 2002).

3. Szimbólum olvasása

„A jelentéshordozók lehetnek sematikus, stilizált részletrajzok, amelyek többnyire tárgyat, emberi alakot ábrázolnak, és a mindennapok gyakorlatában van szerepük" (Pál-Horváth, 2002:3). Ilyenek például a pálcikaemberek, a ruhák címkéjén megtalálható kezelési utasítások, a technikai eszközök működtető gombjai, a tájékozódást segítő piktogramok, közlekedési lámpák és jelzések. Amennyiben az olvasó személy felismeri ezek jelentését, az meghatározza a cselekvését, segíti önálló életvitelét (Pál-Horváth, 2002).

4. Szignálszó olvasása

„A jelentéshordozók absztrakt grafikai alakok többnyire betűsorokból, részben számokból állnak, képelem nélkül” (Pál-Horváth, 2002:4). Itt olyan címkéken, táblákon megjelenő szavakra kell gondolni, amik nagyjából egységesen vannak jelen a világban, meghatározott környezetben jelennek meg. Például minden tejesdobozra rá van írva, hogy tej, de ilyen szignálszó a „vészkijárat” vagy a „WC” szó is. Az olvasó a szóképet felismeri és a helyzettel összefüggésben következtet a jelentésére (Pál-Horváth, 2002).

5. Egész szó olvasása

„A jelek betűcsoportok, mint egész szavak. Írott szimbólumok bizonyos szavak értelmének a megragadására" (Pál-Horváth, 2002:4). Idetartoznak a mindennapi egyszerủ kifejezések, az olvasó saját neve, a hét napjai, a hónapok nevei. Ezen a szinten a tanulók a szavakat ki is mondják, megértik, hogy a beszélt szó megfelel az írott képnek (Pál-Horváth, 2002).

6. Írott szöveg olvasása

„A jelentéshordozók a betűsorozatok mint hangsorozatok jelei, szavak és mondatok" (Pál-Horváth, 2002:5). Ez a szint az egyes szavaktól, a többtagú megállapításokon át, a különböző terjedelmű szövegekig terjedhet. Manapság a gyakorlatban csak erre a szintre törekszünk az értelmileg akadályozott tanulók olvasástanítása során (Pál-Horváth, 2002).

Összefoglalóan elmondható, hogy minden gyermek eljuttatható valamelyik szintre, és minden fokozat értelmes, a hétköznapi életben használható tartalommal tölthető meg (Pál-Horváth, 2002). A gyermekek fokozatosan haladnak elöre a szinteken. A gyógypedagógus feladata, hogy felismerje, melyik gyermek melyik szinten van, és ennek megfelelően készítse el a fejlesztési terveket. Az értékelés az egyes szintek kritériumai szerint zajlik. Ha ennek megfelelően történik az oktatás, minden gyermek olvasóvá válik, megérti a környezetét, és ez pozitívan hat személyiségfejlődésére. A Hublow-módszer minden gyermeket sikerélményhez juttat (Mede, 2010).

A Hublow-módszer megismerését nehezíti, hogy magyar nyelven csak Pál-Horváth Rita (2002) publikált tanulmánya áll rendelkezésre, ezt a cikket idézi Mede Perla (2010) módszerbemutatása is.

\section{NYELVI SZINTEKRŐL}

A magyar nyelvben az írott szövegekre jellemző, hogy különböző megfogalmazással különböző szintű szövegek alkothatók, amelyek olvasása során elvárás az adott szinthez való igazodás. Egyes személyek számára nehézséget jelenthet egy jótállási 
jegy szövegének értelmezése, míg másnak ez nem okoz gondot. Egy jogi szöveg olvasása és értelmezése nehezére eshet bárkinek, aki nem ismeri a szakkifejezéseket. A másik végpont pedig bármely szolgáltató cég hirdetése, mely rövid, tömör és közérthető, hogy minél több ember megértse azt (Farkasné \& Graf-Jaksa, 2009).

Az alábbiakban 4 nyelvi szintezési rendszert fogok bemutatni:

1. Közös Európai Referenciakeret szintjei

2. Gazdasági Együttmüködési és Fejlesztési Szervezet szintjei

3. Könnyen érthető kommunikáció nyelvi szintjei

4. Hublow nyelvi szintjei az olvasástanítás során

Megvizsgálom őket abból a szempontból, hogy mennyire illeszthetők bele ezekbe a rendszerekbe azon értelmi sérült személyek, akik (még) nem képesek a klasszikus értelemben vett olvasás elsajátítására. Minden alfejezetben megjelennek gondolkodásra késztető kérdések, melyek az értelmi sérült személyek olvasási készségének tágabb értelmezését segítik a leírt nyelvi szintezési rendszerekhez viszonyítva.

\section{A Közös Európai Referenciakeret szintjei}

Az Európai Tanács által elfogadott Közös Európai Referenciakeret meghatározza a nyelvtudás szintjeit (Közös Európai Referenciakeret, 2002). Ebben a dokumentumban 5 készségben (hallás, olvasás, társalgás, folyamatos beszéd, írás) 6 szintet különítenek el (A1, A2, B1, B2 ,C1 ,C2). Az 5 készség közül a könnyen érthetö kommunikációhoz a hallás utáni szövegértés és az olvasás kapcsolódik. A témához szorosan az olvasás köthető, ezért ezt szeretném vázlatosan bemutatni.

Az Európa Tanács által jóváhagyott Közös Európai Referenciakeret (KER) nyelvi szintjeinek készségek szerinti leírása
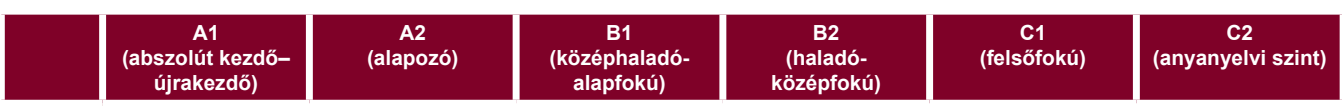

Ha lassan és érthetően Megértem azokat beszélnek hozzám, a kifejezéseket és megértem azokat az általam ismert szavakat és alapkifejezéseket, amelyek rám, a családomra vagy a leggyakrabban elöforduló szavakat, amelyek a legszükebben vett személyes életteremmel kapcsolatosak (pl. a közvetlen környezefontosabb személyi és családi adatok, bevásárlás, környék, munka). A lényeget megértem a rövid, világos, egyszerü üzenetekből és tájékoztatásokból.

Megértem a lényeget az érthető, mindennapi beszéd során, amikor jól ismert, munkahelyen, iskolában, szabadidőmben gyakran felvetődő témákról esik szó. Megértem a lényeget sok olyan rádió- és tévémüsorban, ahol aránylag lassan és érthetően beszélnek az aktuális hírekről, személyes vagy szakmai témákról.

Megértek hosszabb beszédeket és előadásokat, illetve még a bonyolultabb érveléseket is követni tudom, amennyiben a téma számomra elég ismert. Megértem a híreket a tévében, és az aktuális eseményekröl szóló müsorokat. A legtöbb filmet értem, ha a szereplők ismert dialektusban beszélnek bennük.

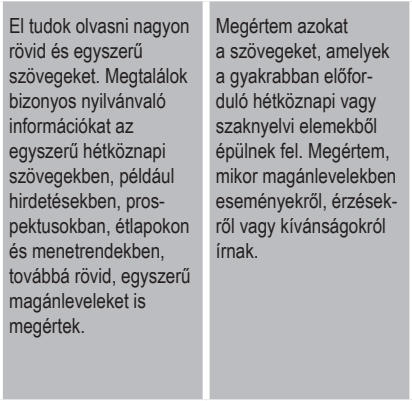

El tudok olvasni olyan cikkeket és beszámolókat, amelyek jelenkori problémákkal foglalkoz nak, és ahol az író egy adott véleményt vagy nézőpontot képvisel. Megértem a kortárs irodalmi prózát. szereplő információkat. neveket, szavakat és a nagyon egyszerü mondatokat, például bizonyos tájékoztató feliratokat, reklámokat pektusokban, étlapokon és menetrendekben, magánleveleket is megértek.
Megértek hosszabb beszédeket még akkor is, ha azok nem világos felépítésüek, illetve ha a kapcsolódások csak közvetettek és nem egyértelmüen jelzettek. Komolyabb erőfeszítés nélkül megértem a tévémüsorokat és a filmeket.

Megértem a hosszú és bonyolult szövegeket, amelyek tényekröl szólnak vagy irodalmi jellegüek, tovább felismerem a stílusbeli eltéréseket. Megértem a speciális témáról szóló cikkeket és a hosszabb, szakmai leírásokat még akkor is, ha azok nem a saját szakterületemmel kapcsolatosak.
Amennyiben van időm a kiejtéshez hozzászokni, nem jelent számomra gondot akár a médián keresztül sugárzott beszéd megértése, még akkor sem, ha a sebesség anyanyelvi szintü.

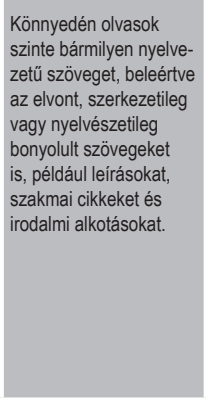

1. táblázat. Közös Európai Referenciakeret szintek. (Forrás: https://nyelviskola.hu/kozoseuropai-referenciakeret-szintek) 
Az A1-töl a C2-ig 6 szinten jól részletezik, hogyan különülnek el az olvasott szöveg értésének fokozatai. Kitérnek olyan részletekre is, hogy milyen jellegű információkat képes az olvasó kiszürni a szövegböl (csak ismerős szavakat vagy megért speciális kifejezéseket). Továbbá, hogy milyen jellegű (hétköznapi vagy tudományos) és hosszúságú (tájékoztató felirat vagy szakmai cikk) írások elolvasására képes az adott szinten lévő személy.

A leírás jól elkülöníti a szinteket, de a könnyen érthető kommunikáció szempontjából hiányérzetünk lehet. Ebben a táblázatban csak a klasszikus értelemben vett olvasás, a betủolvasás jelenik meg. Az olvasás tágabb értelmezése, a képek, képsorok és vizuális jelek olvasása az értelmi sérült személyek esetében kiegészítheti vagy pótolhatja a hagyományosan értelmezett olvasást. Kérdésként merül fel, hogy hogyan lehet ebbe az osztályozási rendszerbe besorolni az értelmi sérült személyek nyelvtudását; különösen azon értelmi sérült személyekét, akik nem tudnak betűket olvasni, de boldogulnak a képekkel. Vajon hogyan lehetne ezt az osztályozási rendszert kiindulási alapnak tekintve egy, az értelmi sérült személyek nyelvi kompetenciájára figyelembe vevő adekvát osztályozási rendszert kialakítani?

Véleményem szerint ebben a rendszerben az értelmi sérült személyek az A1, A2, esetleg a B1 szinteken helyezkedhetnek el. Az is biztos, hogy vannak olyan értelmi sérült személyek, akik nem érik el az A1 szintet sem. Ők is képesek lehetnek információkat értelmezni képekről, szimbólumokról, ha ezt megtanítjuk nekik.

Ezután nézzünk meg egy olyan rendszerezést, ami a szövegértés készségének vizsgálatán alapszik.

\section{Gazdasági Együttmüködési és Fejlesztési Szervezet szintjei}

A Gazdasági Együttműködési és Fejlesztési Szervezet (Organisation for Economic Cooperation and Development, OECD) összehasonlító képességfelmérést végzett a Nemzetközi Felnőtt Képesség- és Kompetenciamérési Program (Programme for the International Assessment of Adult Competencies, PIAAC) keretében. A 16 és 65 év közötti felnőtt lakosságot három körben vizsgálták. A tanulmányom szempontjából a szövegértés készségének vizsgálata a fontos (OECD, id. Horváth, 2020).

Horváth (2020) leírja, hogy az OECD kutatói a szövegértés 6 szintjét különböztették meg, 1-től 5-ig számozva és az 1. szint alatti fokozattal kiegészítve. Ebből most az 1. és az 1. alatti szinteket szeretném kiemelni.

„A szövegértés 1. szintjét elérő felnőttek képesek rövidebb digitális vagy nyomtatott, magánéleti vagy hivatalos stílusban megírt szövegeket elolvasni és megkeresni bizonyos információkat, amelyek azonosak vagy szinonimái az utasításban, kérdésben szereplő szónak. Ezen szövegek kevés ellentmondó információt tartalmazhatnak. Ezt a szintet elérő felnőttek képesek egyszerü kérdőívet kitölteni, értik a mindennapos szavak, mondatok jelentését és képesek egyszerü szöveget folyékonyan elolvasni” (Bunčák és mtsai, id. Horváth, 2020).

„A szövegértésnek az 1. szint alatti szintjét elérő emberek képesek ismert témáról írt rövid szövegeket elolvasni, megkeresni bennük azokat az információkat, amelyek megegyeznek a kérdésben vagy utasításban található információval. Nem volt elvárás a szöveg szerkezetének átlátása, mindössze az alapszókincs szavainak 
megértése. Az alacsonyabb, mint 1. szintnek megfelelő feladatok nem tartalmaztak semmilyen a digitális szövegre jellemző jegyeket" (Bunčák és mtsai, id. Horváth, 2020).

Ebben a rendszerben is csak az írott szöveg megértéséről van szó. Horváth (2020) ismerteti, hogy Baumert szerint az első szinten és az első szint alatt teljesítők lehetnek a könnyen érthető kommunikáció célcsoportjába tartozó személyek. Vajon a könnyen érthető kommunikáció célcsoportjába azok a személyek is beletartoznak, akik nem jutnak el a betűolvasás rutinszerű gyakorlásáig? Ugyanakkor a képek, szimbólumok értelmezése is tágabb értelemben vett olvasás, információszerzés. Az OECD 6 szintjéből is kimaradnak az olvasás tágabb értelmezését alátámasztó szintek, az információszerzés alternatív útjai. Vajon hogyan lehet a különböző vizuális jelek olvasását ebben az osztályozási rendszerben elhelyezni?

Ezt követően pedig vizsgáljunk meg egy olyan nyelvi szintezési rendszert, ami kifejezetten a könnyen érthető kommunikáció nyelvi szintjeit írja le.

\section{A könnyen érthető kommunikáció nyelvi szintjei}

Nyelvi szintezettség megfigyelhető a könnyen érthető kommunikáció módszerével készült kiadványokban is, hiszen az adott célcsoport igényeit szem előtt tartva alakítják a megfogalmazást és választják ki a megértést segítő eszközöket (Farkasné \& Graf-Jaksa, 2009).

A legfontosabb gondolat szerintem a könnyen érthető információ átadással kapcsolatban: „A szintezettség nem egyenlő a szövegek „lebutításával”, ugyanis az információtartalomnak mindig meg kell maradnia. A könnyen érthető módszer a lényegi információk kiemelését jelenti, a lényegtelen nyelvtani környezet háttérbe szorításával" (Farkasné \& Graf-Jaksa, 2009:91).

Farkasné Gönczi (2013) az alábbi szinteket különbözteti meg:

1. szint: Képsorozat

Ennek a szintnek az alkalmazása akkor ajánlott, ha olyan tevékenységet szeretnénk bemutatni, ami részekre bontható. Legjobb, ha valósághủ fényképeket használunk, akár az érintett személy bevonásával elkészítve azokat. Természetesen más szimbólumok vagy ábrák is igénybe vehetők. Egyes esetekben elegendő csak a képek sorozata, néha azonban rövid szöveggel lehet segíteni a képek közötti mozgás megjelenítését. Képsorozattal lehet például segíteni az életviteli vagy munkafolyamatok megértését.

2. szint: Értelmező képek

Ezen a szinten már nem a kép vagy a képsorozat a hangsúlyos, hanem a szöveg. A szövegek mellé helyezett képek segítik az adott mondatok vagy bekezdések megértését. Ebben az esetben is a valósághủ fényképek használata javasolt, ha erre lehetőség van.

3. szint: Témaorientáló képek

A harmadik szinten a kép már csak a téma azonosításában segít az olvasónak, itt már nem a részletek értelmezése céljából van az írás mellett. A szöveg a könnyen érthető kommunikáció írásbeli szabályait figyelembe véve készül, és olvasási képesség szükséges az értelmezéséhez. 
4. szint: Könnyen érthető szöveg kép nélkül

Itt már nincs kép a szöveg mellett, emiatt az olvasónak rendelkeznie kell egy alapszintű olvasási és értelmezési képességgel. A szöveg természetesen a könnyen érthető kommunikáció írásbeli szabályai alapján készül.

A képsorozat szintjén nem veti el a szerzö, hogy szöveges kiegészítés szükséges egy-egy folyamat megértéséhez. Lehet ez egyszerü szövegezésű vagy egyegy mondatos leírás. A szerző ezen a szinten tehát képet és betűt is olvasni tudó személyeket képzel el. Mi történik azonban akkor, ha a célszemély nem tud (még) betűt olvasni? Ebben az esetben olyan képekre, vagy a személy által jól ismert szimbólumokra lehet szükség, amik lehetővé teszik számára a képolvasást, és így a megértést. Azt tapasztalom, hogy vannak olyan értelmi sérült személyek, akiknek szükséges a valósághü fénykép, mert nem tudnak magasabb szinten elvonatkoztatni. Vannak olyan személyek, akiknek elegendő egy sematikus rajz is, vagy egy szimbólum. Emiatt felmerül bennem, hogy a képsorozat szintjét megelőzhetik-e további szintek, akár több is. Kérdés, hogy mik ezek a szintek és, hogyan különülnek el? Ebben a megközelítésben el kell dönteni azt is: a szerző előzőekben idézett rendszere valóban a megértés szerinti szintezés-e, vagy inkább a képek felhasználásának különböző módjairól van „csak” szó?

A következőkben pedig a már ismertetett Hublow olvasástanítási módszer szintezését szeretném bemutatni és értelmezni.

\section{Hublow nyelvi szintjei az olvasástanitás során}

A Hublow módszer szintjeit fentebb részleteztem, emiatt itt csak felsorolás szinten jelenítem meg:

1. Szituációk olvasása

2. Képek olvasása

3. Szimbólum olvasása

4. Szignálszó olvasása

5. Egész szó olvasása

6. Írott szöveg olvasása

Hublow rendszerében az írott szavak, betük a negyedik szinten jelennek meg, és ott is csak szóképek formájában. A szignálszavak és az egész szó szintje között a legnagyobb különbség, hogy az elöbbinél a tanuló a szóképet a megszokott környezetben képes felismerni, míg utóbbinál a környezettöl függetlenül is felismeri a megismert szóképeket. Csak az utolsó, hatodik szint a betűolvasás fokozata, amikor a gyermek a klasszikus értelemben vett olvasásig eljut (Mede, 2010).

Megelőzi a szóképek olvasását Hublow rendszerében a szituációk, a képek és a szimbólumok olvasása. Fokozatosságot épít fel a módszer. A konkréttól az absztrakt felé halad a gyermek az olvasás tanulása során, és Hublow világosan meghatározza a közötte húzódó szinteket. Meggyőző számomra, hogy különválasztja a képeket és a szimbólumokat. A kép lehet ezen szintezés szerint fénykép vagy rajz is, viszont a sematikus rajz, a szimbólum külön szintet képez.

Hublow szintezése véleményem szerint jó kiindulási alap lehet a könnyen érthető kommunikáció nyelvi szintjeinek meghatározására, hiszen az olvasást tágan értelmezi, a képek és a szimbólumok megértésével kibővíti az olvasás fogalmát. Az iskolában az értelmi sérült gyermekek nyelvi kompetenciafejlesztése szempontjából 
érdemes lenne erre fókuszálni. Megjegyzem, hogy az Oktatási Hivatal által 2019ben kiadott új olvasás-írás tankönyvek, melyek értelmileg akadályozott tanulók számára készültek, már építenek a Hublow-féle rendszerezésre.

\section{ESETTANULMÁNY}

\section{Saját tapasztalatok leírása}

Kezdő gyógypedagógusként Szolnokon kezdtem el dolgozni a Liget Úti Általános Iskolában, ami bejáró jellegű, értelmi sérült és autizmus spektrum zavarral élő gyermekek oktató-nevelő intézménye. Itt a 2011/12-es tanévben bíztak rám egy 5. évfolyamos osztályt, ahova értelmileg akadályozott gyermekek jártak. Két éven át minden hétköznap dolgoztam velük. Ennek a két évnek az olvasás-írás tanítással kapcsolatos tapasztalatát szeretném megosztani ebben a fejezetben.

Ahhoz, hogy a hozzáállásomat teljes mértékben meg lehessen érteni, le kell írjam, hogy a föiskola utolsó évében az összefüggő szakmai gyakorlatomat szintén egy akkor 5. évfolyamos, értelmileg akadályozott tanulókból álló osztályban töltöttem. Ez egy nagyon jó képességű csapat volt, 6 gyermekből 2 fő nem tudta az addig tanult betűket elsajátítani, a többi gyermek írt, összeolvasott, és könnyedén vették az új hangok és betűk tanulását. Ezzel a tapasztalattal érkeztem meg két év múlva a saját osztályomba.

2011 szeptemberében azzal az információval vettem át a gyermekeket az előző osztályfönöktől, hogy már kétszer tanulták a gyerekek a harmadik osztályos írás-olvasás tananyagot (tehát a 4 . évfolyamon is ezt vették), de semmit nem tudtak belőle elsajátítani. A harmadikos tanmenet szerint ismerniük kellett volna 7 hangot és betűt (a, i, í, o, ó, m, l) és az írásukat. Nekem is az volt a tapasztalatom az első hónap után, hogy egyik gyermek sem tud a kerettanterv/helyi tanterv szerint elvárt szinten teljesíteni. Nem volt sikerélményük, nekem sem, és így mindnyájan kudarcként éltük meg az olvasás-írás elemei tanórát hetente négy alkalommal.

Az első hónap eltelte után elkezdtem keresni a megoldást, mert éreztem, hogy valamit változtatnom kell. Kutatómunkába kezdtem az interneten, próbáltam az otthon és a könyvtárban lévő szakirodalmakból, cikkekből találni valami iránymutatást. Megkerestem volt tanáromat, Mede Perlát e-mailben, hogy tud-e esetleg valamit ajánlani a problémára. Ő hozta végül a megoldást, tőle kaptam egy diasort a Németországból kiinduló Hublow olvasástanítási módszerről.

Ezután kezdődött a munka oroszlánrésze. Volt 15 darab diában leírásom egy olyan módszerről, amiről előtte nem hallottam, nem láttam ilyen koncepcióval tanuló osztályt, és ebből kellett kidolgoznom valamit, ami a gyermekek számára hasznos és jól alkalmazható. A munkahelyem vezetőségének nagyon hálás vagyok, mert bár segíteni nem tudtak nekem, hiszen nekik sem volt tapasztalatuk, de teljes mértékben szabad kezet kaptam tölük.

Első lépésben a hat szintet igyekeztem értelmezni, megtölteni általam hasznosnak vélt tartalommal. Ezután fel kellett mérnem, hogy szükséges-e a szituációk olvasásától kezdeni az oktatást. Végül arra jutottam, hogy a képolvasás szintjén kell 
kezdenünk, de a betük folyamatosan jelen voltak a tanórákon, dolgoztunk velük még akkor is, ha nem feltétlenül neveztük meg a hozzájuk tartozó hangot.

Elhatároztam azt is (bár ez nem része a Hublow-koncepciónak), hogy nyomtatott nagybetűket fogok használni a szóképek és az írás esetében is. Sokkal egyszerübbnek tartom a gyermeki kezek számára ezek megformázását, és vizuális felismerésük is könnyebb. A teremben minden feliratot nyomtatott nagybetüsre cseréltem, a gyermek jelét pedig felváltotta a nevük nyomtatott változata a poháron, ceruzatartón és az asztalon is. Első tapasztalat az volt, hogy nagyon tetszett a gyermekeknek a sok betű, ami körbevette őket. Büszkén mutogatták az asztalukon a nevüket a bejövő felnőtteknek, gyerekeknek. A nyomtatott nagybetűk előnye volt még, hogy amikor lehetőségünk volt rá, lementünk a számítástechnika terembe, és ott a billentyüzeten is ismerős karakterekkel találkoztak. Ezt később ki is használtuk, néha gyakoroltuk itt az írást a szövegszerkesztő program segítségével.

Beindult a munka és a gyerekek nagyon motiváltak voltak, ez persze engem is buzdított, folyamatosan új ötleteken gondolkodtam, dolgoztam. Nagyon hamar eljöttek az első sikerélmények, én sem gondoltam volna, hogy egy hónap után a gyerekek szárnyalni fognak, de így volt. Első lépésként képesek voltak a csoport tagjainak neveit párosítani: szóképet a szóképpel. Valamint a hat gyermekből négy a saját nevének betűit szét tudta válogatni. Elöször csak a nevükben szereplő három betüt szortírozták szét (mindig más kombinációban), de második tanévben már a nevük összes betüjét képesek voltak elkülöníteni.

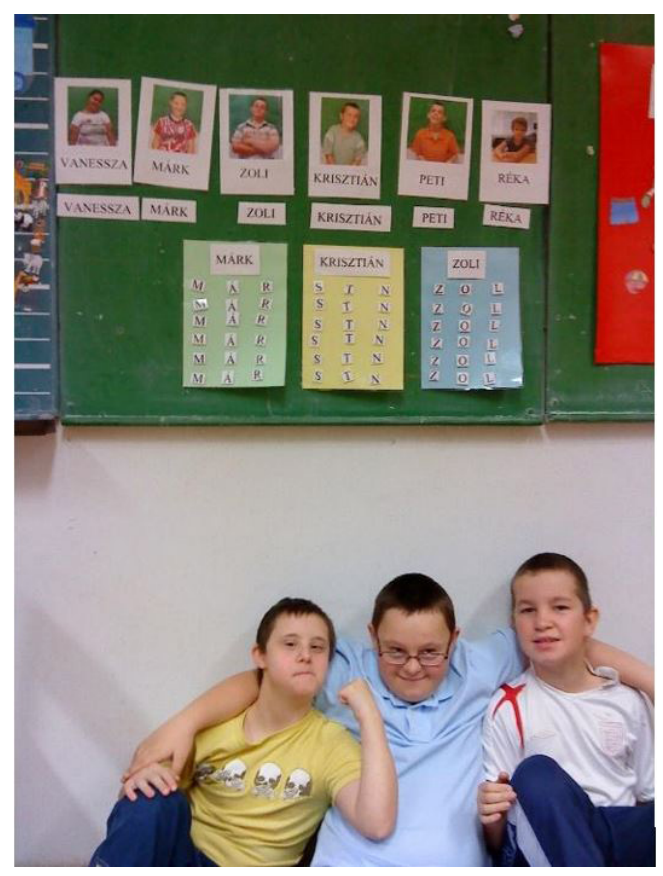

1. kép. A tábla felsö részén a nevek szóképének szóképpel való egyeztetése látható, míg az alsó részen a betük szétválogatása vizuális egyeztetés alapján. 
Ezek persze vizuális egyeztetésen alapuló feladatok voltak, de betűkkel dolgoztak, és meg tudták csinálni. A gyermekek számára ez volt a lényeg, nem pedig az, hogy meg tudják-e nevezni a hangot. Minden órán csináltunk olyan feladatokat, amelyben betűk szerepeltek, mert nagy igényük volt rá, szinte jutalomként tekintettek erre. Valamint dolgoztunk a képolvasáson, majd később a szimbólumolvasáson is. Hatodik osztályra gyártottam nekik egy „tankönyvet”: körülbelül 150 oldalban készítettem feladatokat a szimbólumolvasáshoz, ami abban a tanévben volt meghatározott tartalom az én tanmenetem szerint. Apró, de fontos dolgokban lehetett érezni a változást. Az ügyesebb tanulók felismerték más szavakban a saját nevük kezdőbetűjét, egy gyermek körülbelül fél év után rá tudta írni a rajzaira a saját nevét. Egy alkalommal, amikor sétálni voltunk a városban, egy villanyoszlopon lévő piktogramot felismertek, és mondogatták, hogy: áram, veszélyes. Amikor a takarításról tanultunk életvitel órán, a vegyszereken lévő jelzéseket ők mondták el, hiszen már ismerték őket. A lassabban fejlődő tanulók is sikerélménnyel gazdagodtak, hiszen a képolvasást minden tananyagba bele tudtam szőni, így ők is többet tanulhattak az órákon.

A két év alatt, amíg velük foglalkoztam, a szimbólumolvasás szintjéig jutott az akkor már hétfős csoportból négy gyermek. Egy tanuló a tanulásban akadályozott tanulók tagozatáról került az osztályba a 6 . évfolyamon, ő már tudott ekkor olvasni, tehát ő az írott szöveg olvasása szinten tartott. Két gyermek pedig a képolvasás szintjén maradt, de ott stabilan tudtak teljesíteni.

\section{Eszközök bemutatása}

Az eszközök elkészítésében rengeteg segítséget kaptam az első tanévben az aszszisztensemtöl, aki azonban a 6. évfolyamon sajnos már nem volt az osztállyal. Ekkor viszont egy interaktív tábla segítette a munkámat, amit az olvasás órákon remekül ki tudtunk használni a gyerekekkel. Ebben a tanévben rengeteg digitális tananyag készült: ennek köszönhetően már sokkal kevesebbet nyomtattam, vágtam, lamináltam. Az első tanévben ugyanis rengeteg képet mentettem le az internetről, és készítettem belölük segédanyagot a fenti technikákkal. Igyekeztem olyan eszközöket gyártani, amelyek sokféleképpen alkalmazhatók és nem csak egyszer használatosak. Kifejezetten hasznosnak bizonyultak azok a laminált feladatlapok, amiken bekarikázni kellett a megoldást vagy összekötni az egymáshoz tartozó elemeket. Ezt filctollal csinálták a gyerekek, és a nap végén egyszerüen le tudtam törölni róla a filcet. Elég volt egyszer megszerkeszteni 5-6 féle feladatlapot ugyanarra a témára, így nem is került kétszer ugyanaz a feladat egy gyermek elé.

Minden gyermeknek volt egy saját doboza a nevével, ami tele volt a tanult képekkel és hozzá tartozó szóképekkel, természetesen tananyagok szerint csoportosítva. Ugyanezek a képek és szóképek nagyban megvoltak nekem, így sokszor csak felmutattam nagyban, ők pedig betűsínbe rakták ugyanazt kicsiben. Volt az osztálynak egy közös olvasókönyve, ebbe füztük bele a már tanult képeket, szavakat. Jó volt látni a gyerekeknek és nekem is, hogy egyre bővült a könyv tartalma. A betüsínbe a nevüket is sokszor kirakták minta alapján, persze eleinte csak a szükséges betük álltak a rendelkezésükre, később már több betüből kellett kiválogatni a megfelelőket. 

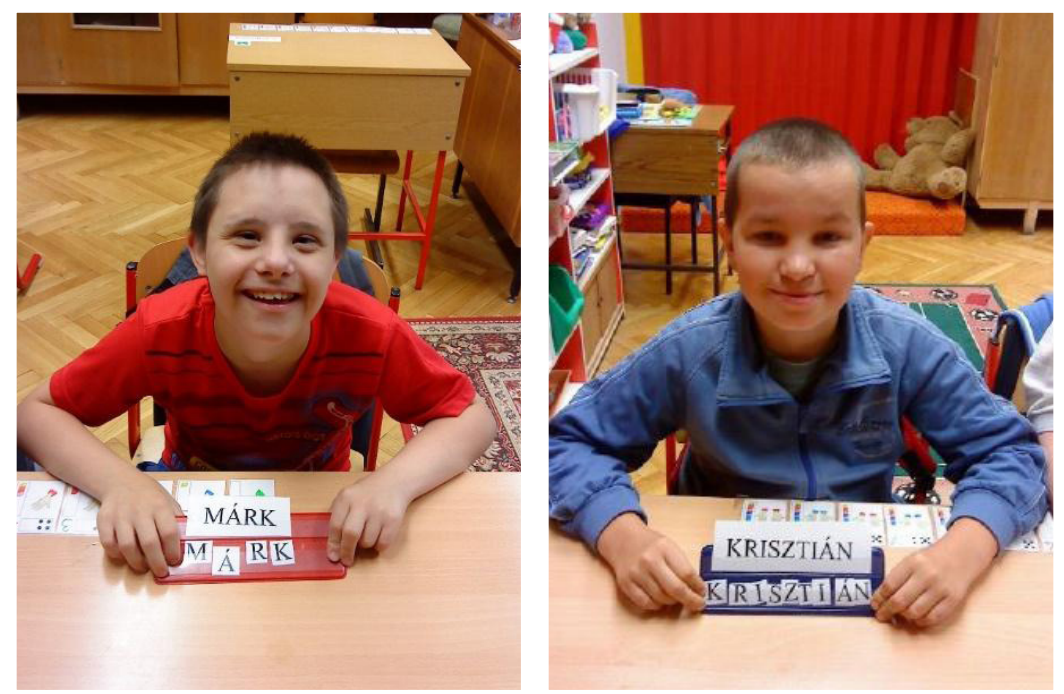

2. kép. Szókép alapján név kirakása betükből

Mindent lamináltam, és sokszor használtam az öntapadós tépőzárat is az eszközök készítésekor, hiszen ezzel is újra meg újra lehetett gondolni egy-egy feladatot. Volt olyan eszköz, melynek az egyik oldala filctollal használható feladatlap volt, a másik oldalán a tépőzárak segítségével szóképet képpel, illetve betűt betűvel lehetett egyeztetni.

Minden gyermeknek volt egy betűtáblája is, amin korongok segítségével lehetett bejelölni az általam nagyban mutatott betüt, vagy a neve betüit. Szerettem ezt a feladattípust, a szimbólumolvasáshoz is készítettem nekik ilyen táblázatot a tanult piktogramokkal a tankönyv minden témaköréhez.

Amikor a szimbólumokat tanultuk, volt olyan, amit könnyen megtaláltam az interneten, de volt olyan, amit saját kezüleg kellett megrajzolni.
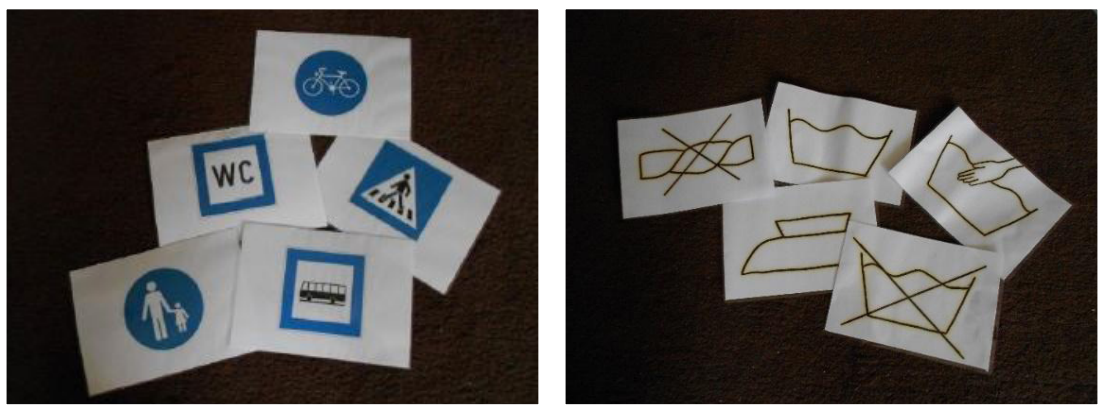

3. kép. Képek a szimbólum olvasáshoz nyomtatásban és kézzel rajzolva (KRESZ-táblák és ruhacímkén megjelenő piktogramok)

Minden alkalommal, amikor új témakört kezdtünk, sokáig gyűjtöttünk képeket a szimbólumokhoz, fontos volt, hogy megértsék, amiröl beszéltünk. A gyűjtött képek alapján nagyon sokat lehetett beszélgetni a gyerekekkel az adott témáról. 


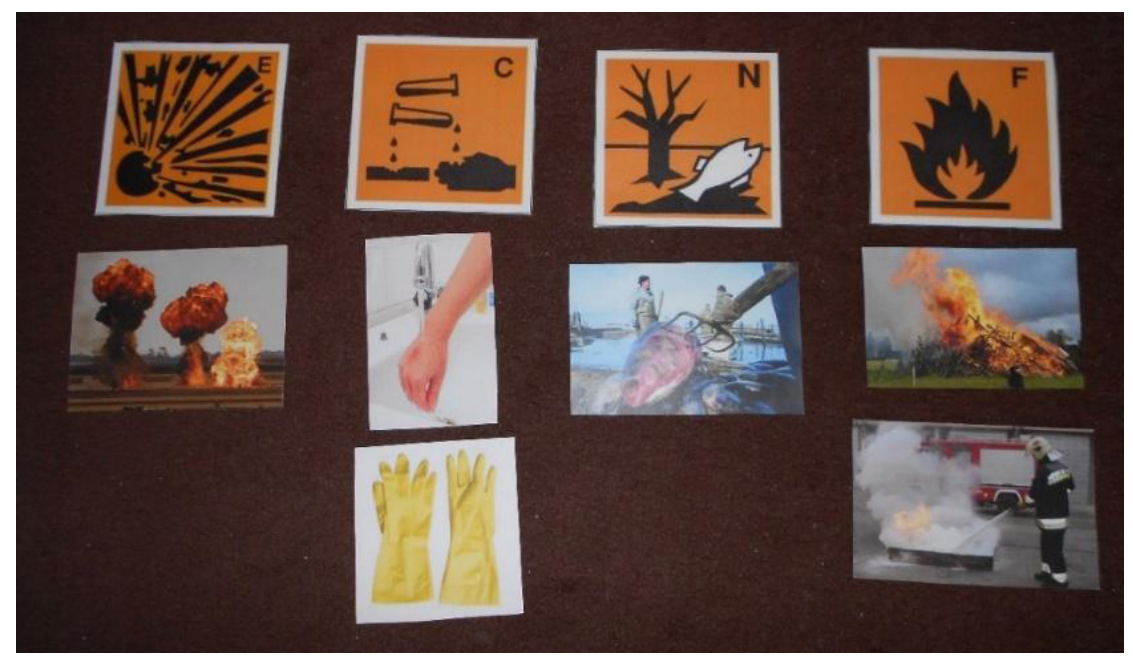

4. kép. Képek gyüjtése a szimbólumokhoz a tanulási folyamat elején (vegyszereken megjelenö piktogramok)

Iskolánk rendelkezik Boardmaker-programmal, aminek nagy hasznát vettem, amikor cselekvésekről tanultunk. A tevékenységet kifejező szavakkal mondatokat is tudtunk alkotni. Elöször a tanuló képe és a cselekvés képe kerültek egymás mellé, és úgy olvastuk le, hogy például: Zoli iszik. Később már a gyermek neve is megjelent a kép alatt, majd amikor már biztosan felismerték a saját nevüket és a társaik nevét a szóképröl, akkor csak a név került a cselekvés mellé, és úgy olvastuk el a mondatot.
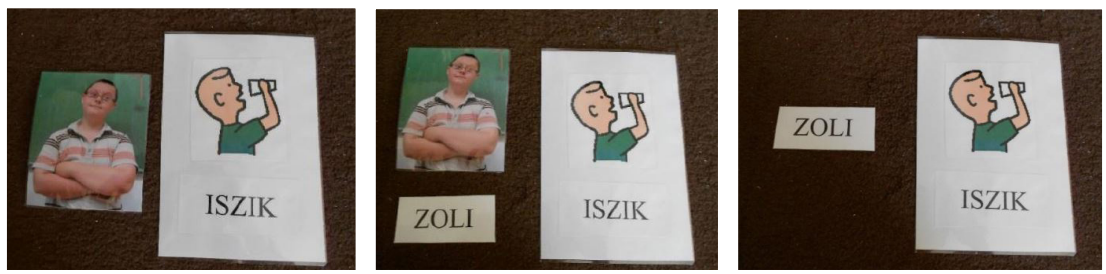

5. kép. Mondatalkotás eleinte fényképpel, majd névvel és cselekvést ábrázoló képpel

\section{A tanmenetírás folyamatáról}

A tanmeneteket egyedül írtam a két tanév során, de a munkaközösség vezetője mind a két esetben átnézte, ami számomra megnyugtató volt. Én magam sem tudtam, hogy pontosan milyen tempóban fogunk tudni haladni az anyagrészekkel, mi az, ami könnyedén fog menni, és mi az, ami nehézséget fog okozni. Ezért mind a két tanévben változott a tanmenet év közben is. Volt, hogy valamire több idő kellett, volt, hogy valamire kevesebb. Alapvetően az volt a tapasztalatom, hogy összességében lassabb tempóban érdemes haladni, mint azt a tanév elején elképzeltem. Túl sok tananyagot próbáltam belepréselni egy évbe, és kevés időt hagytam a tervezés során a gyakorlásra, ismétlésre, ezért kellett időközben korrigálni. 
Mivel a tantárgy neve akkor olvasás-írás elemei volt ,és a Hublow-módszer csak az olvasástanitást fedi le, ezért a tanmenetben meg kellett jelennie az írásnak is. Ezért minden óra tananyagához hozzárendeltem a tervezés során írásfeladatot is, úgy hogy az kapcsolódjon az adott témához. Például ha a közlekedési jelzésekröl tanultunk szimbólumolvasásból, akkor a rövidebb közterületek átírása/másolása/írása volt a feladat (út, utca, tér).

\section{ÖsszegzÉs}

A tanulmányban megismerhette az olvasó a könnyen érthető kommunikáció módszerét, a Hublow olvasástanítási módszert, és megvizsgáltam különböző nyelvi szintezési rendszereket. Ezeket összevetettem a saját tapasztalatommal, amit az értelmi sérült gyermekek tanítása során szereztem, és az esettanulmányi részben ismertettem. A könnyen érthető kommunikáció újfajta szintezésére teszek ezek alapján javaslatot:

1. Képek szintje

Rajzok, festmények, élethü képek formájában.

2. Szimbólumok szintje

Sematikus rajzok, szimbólumok, piktogramok megjelenítése.

3. Egész szavak szintje

A téma szempontjából fontos szavakkal kifejezett tartalom.

4. Mondatok szintje

Néhány tőmondattal megfogalmazott tartalom.

5. Szövegek különböző terjedelemben

A szöveg készítésénél figyelembe kell venni a könnyen érthető kommunikáció alapelveit, irányelveit és az útmutatóban leírtakat.

A fenti szinteket a Hublow-szintezésre alapozott saját szakmai tapasztalataim alapján állítottam össze. Más életkorú, a sérülés más fokán álló értelmi sérült személyekkel ezek meghatározása változhat.

A könnyen érthetö kommunikáció módszere megoldást jelenthet sok értelmi sérült személy számára, hogy könnyebben eligazodjanak a világban, ezáltal nagyobb önállóságra tegyenek szert. A Hublow olvasástanítási módszer megjelenését nagyon fontosnak tartanám az értelmi sérült gyermekeket oktató intézményekben, hiszen alternatívát ad: ha nem sikerül valamit elérni az egyik úton, elindulhatunk egy másikon. Ha alaposan megismertük a gyermeket, és több évi közös munka után azt látjuk, hogy nem hoz eredményt a szintetizáló olvasástanítás, akkor van lehetőség váltásra. Több sikerélményhez juttathatjuk a gyermeket, és pozitív hatással lehetünk a jövőjére is, hiszen az információszerzés és értelmezés nagyobb fokú önállóságot biztosíthat számára a felnőtt életben. Ennél a pontnál fonódik össze a könnyen érthető kommunikációval a Hublow olvasástanítási technika. Összességében a két módszer kapcsolatát abban látom, hogy a könnyen érthető kiadványokat, anyagokat azok tudják olvasni, akiket erre készítenek fel. Mivel a könnyen érthető kommunikáció sem csak a könnyen érthető szövegek értelmezéséről szól, hanem például képekről, sorozatképekröl is, a Hublow-módszer pontosan erre készíti fel az olvasni tanuló fiatalt. 


\section{Irodalom}

2/2005. (III. 1.) OM rendelet a Sajátos nevelési igényű gyermekek óvodai nevelésének irányelve és a Sajátos nevelési igényű tanulók iskolai oktatásának irányelve kiadásáról

1998. évi XXVI. törvény a fogyatékos személyek jogairól és esélyegyenlőségük biztositásáról

a Fogyatékossággal élő személyek jogairól szóló ENSZ egyezmény, 2006

a fogyatékossággal élő emberek esélyegyenlőségének alapvető szabályai, $1993 \mathrm{http} / / /$ docplayer. hu/1230626-A-fogyatekossaggal-elo-emberek-eselyegyenlosegek-alapveto-szabalyai. html Letöltés ideje: 2021.03.31.

Chinn, D. \& Homeyard, C. (2017). Easy read and accessible information for people with intellectual disabilities: Is it worth it? A meta-narrative literature review. Health Expectations, 2017.20:1189-1200. https://doi.org/10.1111/hex.12520

Csató Zs. (szerk.) (2002). Egyszerủen, érthetően: útmutató könnyen érthető tájékoztatók készítéséhez. ÉFOÉSZ, Budapest.

Farkasné Gönczi R. \& Graf-Jaksa É. (2009). Könnyen érthető kommunikáció. In Pandula A., Szatmári P., Vincze T., Farkasné Gönczi R. \& Graf-Jaksa É. (szerk.), Kommunikációs és információs technológiák és fogyatékosságügy. ELTE Bárczi Gusztáv Gyógypedagógiai Kar, Budapest. 80-100.

Farkasné Gönczi R. (2013). Könnyen érthető kommunikáció nyelvi szintjei. Gyógypedagógiai Szemle, 41.3:208-212.

Gruiz K. (évszám nélkül). Hogyan készítsünk könnyen érthető segédanyagot? - Irányelvek. Down Alapítvány, Budapest.

Horváth P. L. (2017a). Adalékok a könnyen érthető kommunikáció nemzetközi történetéhez. Gyógypedagógiai Szemle, 45.3:159-174.

Horváth P. L. (2017b). Érthető számodra a világ? Ha nem, tedd érthetőbbé! Carissimi, VIII.5:810.

Horváth P. L. (2020). A könnyen érthetö kommunikációs képzési programok képzésfejlesztésének története Magyarországon a fogyatékossággal élő személyek jogairól szóló ENSZ egyezmény tükrében. (Doktori értekezés.) Eszterházy Károly Egyetem Neveléstudományi Doktori Iskola, Eger.

Inclusion Europe \& ÉFOÉSZ (2009a). Információt mindenkinek! A könnyen érthetö kommunikáció európai alapelvei. Inclusion Europe - ÉFOÉSZ, Brüsszel - Budapest.

Inclusion Europe \& ÉFOÉSZ (2009b). Ne írjon nekünk, nélkülünk! - Hogyan vonjunk be értelmi fogyatékossággal élő embereket könnyen érthető szövegek készitésébe? Inclusion Europe - ÉFOÉSZ, Brüsszel - Budapest.

Irányelvek a sajátos nevelési igényű tanulók iskolai oktatásához (2020). https://www.oktatas.hu/ pub_bin/dload/kozoktatas/kerettanterv/SNI_iranyelvek.docx Letöltés ideje: 2020.12.21.

Közös Európai Referenciakeret (2002). https://nyak.oh.gov.hu/nyat/doc/ker_2002.asp Letöltés ideje: 2021.03.31.

Mede P. (2010). Értelmileg akadályozott gyermekek olvasás-írás tanítása. In Radványi K. (szerk.), ¿MÁSKÉ(P)P? Intellektuális fogyatékossággal élő emberek gyógypedagógusainak tankönyve. ELTE Bárczi Gusztáv Gyógypedagógiai Kar, Budapest. 63-75.

Olvasás-írás kerettanterv a középsúlyosan értelmi fogyatékos tanulók számára 1-8. évfolyam (2020). https://www.oktatas.hu/pub_bin/dload/kozoktatas/kerettanterv/ksni_1_8/Olvasas-iras.doc Letöltés ideje: 2021.03 .31 .

Pál-Horváth R. (2002). Olvasni? Egy más felfogásban. Kapcsolatok. Magyar Gyógypedagógusok Egyesülete Értelmileg Akadályozottak Szakosztálya, Budapest. 7-9.

Sajátos nevelési igényű gyermekek óvodai nevelésének irányelve, 2020. https://www.oktatas. hu/kozneveles/kerettantervek/2020_nat/iranyelvek_alapprogramok Letöltés ideje: 2021.03.31.

Sutherland, R. J. \& Isherwood, T. (2016). The Evidence for Easy-Read for People With Intellectual Disabilities: A Systematic Literature Review. Journal of Policy and Practice in Intellectual Disabilities, 13.4:297-310. https://doi.org/10.1111/jppi.12201

Szabó B. (2006). Inkluzív nevelés - Ajánlások értelmileg akadályozott gyermekek, tanulók kompetencia alapú fejlesztéséhez - Szövegértés-szövegalkotás. suliNova Közoktatás-fejlesztési és Pedagógus-továbbképzési Kht., Budapest. 


\section{Hatékonyabban támogatja-e a könnyen érthetö üzenet az értelmileg akadályozott tanuló fözési folyamatát a sztenderd üzenetnél?}

\begin{abstract}
Magyarországon az értelmileg akadályozott tanulók általános iskolájában, a 6. osztályban kötelezően oktatandó ismeretkör a zacskós leves készítése. Felvetődik a kérdés, vajon képesek-e a 6. osztályos tanulók a zacskós levest a tasakon olvasható leírás alapján elkészíteni? Vajon segítséget jelent-e nekik a tanulási folyamatban, ha a zacskós leves elkészítésének folyamatát könnyen olvasható és érthető formában is rendelkezésre bocsátjuk?

$\mathrm{Az}$ empirikus kutatást - az érintett tanulók és szüleik írásos beleegyezésével - egy dél-alföldi szegregált iskolában végeztük el. A kutatásba 8 értelmileg akadályozott tanulót vontunk be. A zacskós levest 4 fö először a tasakon olvasható leírás, majd egy hónappal később a tanulmány szerzője által készített könnyen olvasható és érthető leírás alapján készítette el. 4 fö fordított sorrendben dolgozott. A könnyen érthető szöveges-fényképes és csak fényképes, 30 lépésből álló folyamatot bemutató recepthez a valós helyszínen készültek a fényképek. A fözési folyamat eredményességét nyilvánvalóan nem csak a recept érthetősége befolyásolja. Annak érdekében, hogy más tényezőket jó eséllyel kizárjunk, közel azonos jellemzőkkel bíró tanulókat választottunk ki. Figyelembe vettük a tanulók nyelvi kompetenciájának szintjét (tud-e olvasni), a zacskós leves készítésével kapcsolatos előzetes ismereteiket (P-A-C teszt, gyógypedagógusi interjúk, személyes megfigyelés).

A teljes fözési folyamatról videofelvétel készült. A videofelvételeket elemezve látjuk, hogy a zacskós levest a kutatásban részt vevő tanulók a tasakon lévő recept alapján, további segítség nélkül nem tudják elkészíteni. Ugyanakkor a második fözés attól függetlenül sikeresebb, hogy az első fözést a tasakon lévő vagy a könnyen olvasható és érthető recept alapján teljesítették a tanulók. A gyakorlásnak, az ismétlésnek tehát nagyobb szerepe lehet, mint magának az érthetőségnek. Ugyanakkor a könnyen olvasható és érthető recept alkalmazása egyrészt láthatóan nagyobb sikerélményt biztosít, másrészt hatékonyabban segíti elő a tanulási folyamatot a sok nehézséget és kudarcélményt okozó tasakon lévö recept alkalmazásával szemben.
\end{abstract}

Kulcsszavak: könnyen érthető kommunikáció, érthetőség, kerettanterv, felső tagozat, kutatási eredmények, zacskós leves készítése

\section{BEVEZETÉS}

A tanulmány a könnyen érthető kommunikáció témája köré épül. Munkám során arra vállalkozom, hogy egy eredeti, zacskós levesen található elkészítési útmutató leírásának értelmezését összevessem ugyanazon zacskós leves könnyen érthető elkészítési útmutatójának érthetőségével. Magyarországon ilyen jellegű kutatás még nem született. Így különösen motivált vagyok arra, hogy a kutatási eredményekkel segítsem az értelmileg akadályozott személyek életét.

Elengedhetetlennek tartom, hogy a könnyen érthető kommunikációról teljes és valós képet kapjunk. Szeretnénk azt hinni, hogy a könnyen érthető kommunikáció minden értelmileg akadályozott személy számára megfelelő, jól alkalmazható módszer: ennek tudományos bizonyítására azonban eddig Magyarországon nem került sor.

Ebben a tanulmányban az elvégzett kutatás módszertanát, az általam készített könnyen érthető anyagokat mutatom be. Az eredményeket egy svájci konferencián ismertetem 2021 augusztusában. 


\section{VÁZLATOS SZAKIRODALMI ÁTTEKINTÉS}

\section{A célcsoport megjelölésére használt fogalmakról}

A gyógypedagógiában használatos fogalmak az évek során folyamatosan változáson mennek keresztül. Itt és most az általam vizsgált célcsoport meghatározásának egyik változatát mutatom be.

„Az értelmi akadályozottságot (értelmi fogyatékosság egyik részcsoportját) egy három egységből álló fogalomként foghatjuk fel az egyéni károsodással, mely tanulási és fejlődési korlátozottsághoz vezet, és társadalmi hátrányokat von maga után. Az ilyen lineáris szemlélet azonban ma már nem megfelelően jellemzi az értelmi fogyatékosság/akadályozottság jelenségét. A valóságban mindig kölcsönhatásokkal és cirkuláris folyamatokkal találkozunk, úgy, hogy a biológiai, pszichikai és szociális tényezők kölcsönös együtthatásából kell kiindulni" (Hatos, 2015:8).

Jelen tanulmányban a célcsoport megnevezésére az értelmileg akadályozott, illetve az értelmi sérült kifejezést használom. Némely esetben, amikor szó szerint idézek, nem tudok eltekinti az eredeti szövegben megfogalmazottaktól.

\section{Emberi jogi alapok}

A Fogyatékossággal élő személyek jogairól szóló ENSZ egyezményt kihirdető 2007. évi XCII. törvény a fogyatékos személyek - beleértve az értelmileg akadályozott személyeket is - jogairól szól: „...célja valamennyi emberi jog és alapvető szabadság teljes és egyenlő gyakorlásának előmozdítása, védelme és biztosítása valamennyi fogyatékossággal élő személy számára, és a velük született méltóság tiszteletben tartásának elömozdítása" (fogyatékosságügyi ENSZ egyezmény 1. cikk).

Ha különböző fogyatékossági típusokra gondolunk, általános kép él az emberek fejében arról, kit hogyan közelítünk meg, kihez milyen módon tudunk közelebb férkőzni. Tudjuk, hogy a siket és nagyothalló emberekkel jobbára jelnyelvvel kommunikálunk, a vak és gyengénlátó emberek Braille-írást használnak, sőt a különböző augmentatív és alternatív kommunikációt kínáló eszközök is egyre elterjedtebbé válnak. De mi a helyzet az értelmileg akadályozott személyekkel? „Jó lenne, ha (...) legalább ugyanennyire ismertté és alkalmazottá válna az értelmi sérült emberek tájékozódását segítő könnyen érthető kommunikáció" (Horváth, 2017a:9).

„Az ENSZ fogyatékossággal élő személyek jogairól szóló egyezményét és annak fakultatív jegyzőkönyvét Magyarország az elsők között írta alá 2007-ben és ezután a XCII. törvénnyel ratifikálta is (...) Az államok olyan rendelkezések és intézkedések törvénybe iktatására kötelezik magukat, amelyek elősegítik a fogyatékossággal élő emberek jogainak érvényesülését" (Farkasné Gönczi \& Graf-Jaksa, 2009:84-85).

Az egyezmény 9 . cikke ír a fogyatékossággal élő személyek önálló életvitelét (és társadalmi részvételüket) segítő intézkedésekröl. Ilyen intézkedések „a fizikai környezethez, a közlekedéshez, az információhoz és kommunikációhoz, beleértve az információs és kommunikációs technológiákat és rendszereket, valamint más nyilvánosan hozzáférhető vagy rendelkezésre álló lehetőségekhez és szolgáltatásokhoz való hozzáférést, mind a városi, mind vidéki területeken" (fogyatékosságügyi ENSZ 
egyezmény 9. cikk). Ebben a cikkben esik szó a könnyen érthető kommunikációról is, melynek értelmében biztosítani kell a könnyen érthető és olvasható jelzéseket az értelmileg akadályozott személyek számára.

A 21. cikk arról szól, hogy a fogyatékossággal élő személyek számára az általuk választott kommunikációs formát, eszközöket és módozatot kell biztosítani.

Ahogyan a fogyatékosságügyi ENSZ egyezmény 29. cikkéböl kiderül, a könnyen érthető kommunikációval olyan, az ember jogait érvényre juttató tevékenységekhez való hozzáférést is igyekeznek biztosítani, mint a politikai és közéletben való részvétel.

\section{A könnyen érthetö kommunikáció meghatározása}

Farkasné Gönczi (2018:70) szerint „a könnyen érthetö kommunikáció a köznyelvben megjelenő információ fontos tartalomegységeinek megjelenítése, vagy önálló információs tartalom kidolgozása egyszerü, letisztult formában, mely az információ megértését szolgálja. Az információ könnyen érthető kommunikáció alkalmazásával történő feldolgozását az adaptáció tartalmi és formai szabályainak betartása mellett a képek és illusztrációk adekvát alkalmazása segíti."

Horváth (2019:63) megfogalmazása alapján „a könnyen érthetö üzenet kódolása alatt azt a folyamatot értjük, amikor a közlő a beszélt, az írott, a képi vagy a filmes üzenetét az üzenet befogadójának, azaz az értelmi sérült személynek a dekódolási, azaz az üzenet észleléséhez, érzékeléséhez és értelmezéséhez szükséges kompetenciájához illeszkedő, írott kódolási szabályok szerint fogalmazza meg."

\section{A könnyen érthetö kommunikáció az értelmileg akadályozott tanulók oktatásához készített keret- tantervekben}

Kutatásomban a zacskós leves tényleges elkészítésével vizsgálom a könnyen érthetőnek és olvashatónak szánt anyag és az eredeti, a zacskós leves zacskóján olvasható leírás érthetőségét.

A kommunikáció; a számolás-mérés; a játékra nevelés; a társadalmi ismeretek; az önkiszolgálás; a technika, életvitel és gyakorlat; a környezetismeret; az ének-zene; az ábrázolás-alakítás; az információs eszközök használata; a mozgásnevelés és a testnevelés tantárgyakhoz készített kerettantervek olvasása során egy alkalommal sem találkoztam sem a „könnyen érthető”, sem az „egyszerüen érthető” kifejezésekkel. Az olvasás-írás tantárgy kerettantervének elemzése során bukkantam rá kizárólag az alábbi szövegrészletre: „A középsúlyos értelmi fogyatékos tanuló esetében a pedagógusok feladata elérni, hogy az életkornak és az egyéni képességeknek megfelelő olvasási és írási technikák folyamatos fejlesztésével és alkalmazásával a tanuló legyen képes az információkat elemi szinten megszerezni, átadni, legyen képes könnyen érthetö, rövid szöveg elolvasására, értelmezésére, néhány egyszerü gondolat leírására egyre kevesebb segítséggel" (olvasás-írás kerettanterv 1-8. osztály, 2020:1).

Az olvasás-írás tantárgy kerettantervében az általános iskola 5-6. évfolyamán, az értő olvasás témakörben jelenik meg a zacskós leves készítése mint fejlesztési 
feladat (olvasás-írás kerettanterv 1-8. osztály, 2020:19). Tény, hogy az elnyújtott betűtanítás miatt ezen az osztályfokon még nem minden betút ismernek a tanulók, így ez a feladat irrelevánsnak bizonyul. Ez is egy oka annak, hogy kutatásomba nem a 6., hanem a 7-10. évfolyamon tanulókat vontam be.

Azért választottam tehát éppen a zacskós leves elkészítését, mert ez az ismeret szerepel a kerettantervben. Egyúttal az általam készített könnyen érthető elkészítési útmutatóval példát tudok mutatni a kerettantervben megjelenő alapelv gyakorlati megvalósítására.

\section{Könnyen érthető receptek a konyhában}

„Az értelmileg akadályozott gyermekek és felnőttek társadalmi életben való aktív és egyenjogú részvételének egyik fontos feltétele, hogy eljussanak hozzájuk az írott és a hangzó információk és megérthessék azokat; ily módon képesek legyenek tájékozódni az öket körülvevő világban" (Horváth, 2017b:23).

Éppen ezért szeretnék szerepet vállalni abban, hogy az értelmileg akadályozott személyek megismerkedhessenek a konyhával, hozzásegíteni őket ahhoz, hogy egyszerü - vagy akár bonyolultabb - ételeket is elkészíthessenek.

Magyarországon Farkasné Gönczi (2019) hozott létre egy blogot, melyen bárki másodpercek alatt hozzáférhet könnyen olvasható és érthető receptekhez. A honlapon egyszerüen kezelhetően, kategóriákba sorolva találhatók meg a különböző ételcsoportok. A szerző igyekszik „egyszerü megfogalmazással és instrukciókkal, lépésekre bontva, a konyhai tevékenységek könnyebb érthetősége kedvéért képekkel segítve" (Szebelédi-Kurucz, 2012:286) leírni a különböző ételek elkészítésének folyamatát.

\section{MEGELŐZő KUTATÁSI TAPASZTALATOK A KÖNNYEN ÉRTHETŐ ANYAGOK ÉRTHETŐ- SÉGÉNEK VIZSGÁLATA TÉMAKÖRÉBEN}

Az Egyesült Királyságban Sutherland és Isherwood 2016-ban készített egy szisztematikus szakirodalmi áttekintést. Adott elektronikus adatbázisokból szisztematikus módon gyűjtött források meghatározott elemzési szempontok szerinti áttekintése során azt találták, hogy 2013 novembere és 2014 januárja között 11 publikáció született, amelyekben megkísérlik felmérni a könnyen érthető kommunikáció hatékonyságát. A tanulmány legfontosabb megállapítása, hogy vannak már olyan bizonyítékok, amelyek alátámasztják, az értelmi sérült személyek esetében a könnyen érthető anyagokkal hatékonyabban tudjuk az információt átadni, mint a sztenderd szövegekkel. Az azonban még nem egyértelmü, hogy például a szimbólumok, képek (vonalrajzok) és fényképek használata is támogatja-e az értelmezés folyamatát. Ugyanakkor a fényképek kizárólagos használata előnyös lehet az értelmi sérült emberek egyes csoportjai számára. A könnyen érthető üzenetek készítésének támogatására létrejött szabályrendszerek által javasolt, a kiadványok arculatára vonatkozó szabályok betartásának szükségességét azonban kevés bizonyíték támasztja alá. 


\section{A VIZSGÁLAT MÓDSZERTANA}

\section{A kutatási kérdés}

Nem állítottam fel hipotézist, helyette kutatási kérdést fogalmaztam meg. „A jó hipotézis fontos tulajdonsága, hogy lehetöség szerint új ismeretek, megközelítések felé mutat, meghaladja a korábbi ismereteket, vagy megkérdőjelezi azokat" (Boncz, 2015:20). Magyarországon azonban ilyen jellegű kutatás még nem született, így kevéssé tűnt helyes útnak a hipotézis felállítása. A kutatás során tehát arra a kérdésre keresem a választ, hogy az értelmileg akadályozott tanulók fözési folyamatát hatékonyabban támogatja-e a könnyen érthető recept a sztenderd receptnél?

\section{A kutatás alanyai}

Kutatásom során értelmileg akadályozott tanulók körében vizsgálom a könnyen érthető kommunikáció hatékonyságát. Mint később kiderült, a kutatás megkezdése előtt kialakított tervem több ponton is változtatást igényel. Az alábbiakban az eredeti tervemet mutatom be. A felmerült problémákat és az ezeknek okán történő változtatásokat „A kutatás tényleges előkészítését befolyásoló tényezők” című fejezetben foglaltam össze.

Az alapsokaságból nem valószínüségi mintaválasztással jelöltem ki a bevont személyeket. A kiválasztásnál figyelembe vettem a tényt, hogy értelmileg akadályozott tanulók számára íródott kerettantervben, az általános iskola 5-6. évfolyamán jelenik meg a zacskós leves készítése az olvasás-írás tantárgy keretein belül.

A kutatás megvalósíthatósága érdekében, a létező kapcsolati hálómra tekintettel, valamint a korábban szerzett megannyi jó tapasztalatom miatt a hódmezővásárhelyi Kozmutza Flóra Óvoda, Általános Iskola, Szakiskola, Kollégium, Egységes Gyógypedagógiai Módszertani Intézményre esett a választásom. A kutatásban részt vevő értelmileg akadályozott tanulókat tudatosan választottam ki.

Az eredeti elgondolás szerint, a kerettantervi előírásoknak megfelelően, a felső tagozatos értelmileg akadályozott tanulók képezték a célcsoportot.

Célom az volt, hogy a mérésbe az alábbiakban bemutatásra kerülő két változó (nyelvi kompetencia, előzetes tudás) mentén hasonló tulajdonságokkal rendelkező személyek kerüljenek. Így 20 tanulót szerettem volna bevonni a mérésbe, akik közül azt a 10 tanulót szándékoztam bevonni a kutatásba, akik azonosnak vagy közel azonosnak mondható nyelvi kompetenciával és előzetes tudással rendelkeznek. Első lépésként, a Pedagógiai Analízis és Curriculum (P-A-C) mérőeszközzel szándékoztam a tanulók előzetes nyelvi kompetenciáját felmérni. Mivel magához a zacskós leveshez, egyáltalán a konyhai munkához kapcsolódó előzetes tudást is szándékomban állt megismerni, így a tanulókkal foglalkozó gyógypedagógusoktól félig strukturált interjú formájában volt célom információkat gyűjteni. A tanulókról kialakítandó kép érdekében szerettem volna előzetesen rögzített szempontok alapján megfigyelni azt a folyamatot is, amikor a tanulók a zacskós levest a gyógypedagógus irányítása mellett készítik el. Arra is tekintettel voltam hogy a megfigyelésre nem biztos, hogy lehetőségem lesz, így ezt eleve többletinformációnak tekintettem. Miután kellő adat 
állt volna a rendelkezésemre a tanulók nyelvi kompetenciájáról és a zacskós leves készítésével összefüggő előzetes tudásukról, a 20 tanulóból ki tudtam volna szürni azt a 10 tanulót, akinek a legközelebb esik egymáshoz a nyelvi kompetenciája és az előzetes tudása.

A kísérletbe végül 8 tanulót tudtam bevonni. Ennek okát később „A kutatás tényleges előkészítését befolyásoló tényezők" címü fejezetben fejtem ki.

4 tanuló először a zacskós levesen olvasható, a másik 4 tanuló pedig a könnyen érthető leírás alapján készítette el az ételt. Négy hét elteltével a főzést megismételték, ahol az első 4 tanuló most a könnyen érthető, a másik 4 tanuló pedig az eredeti szöveg alapján fözött.

\section{A kutatás módszere}

A kvalitatív kutatás egyik lényeges tulajdonsága, hogy a kutatást vezető személy magaviselete, feltett kérdései, megnyilvánulásai, nyitottsága újabb kérdések felvetésére adnak lehetőséget; az ezekre adott válaszok újabb és újabb adatokkal szolgálhatnak (Sántha, 2009). A kvalitatív kutatási módszerek közül a megfigyelésen (egyfajta kísérleti helyzeten) alapuló összehasonlító elemzés módszerét alkalmaztam. A természetes kísérletet a tanteremben, vagy egy másik, tanulásra alkalmas helyen végzik; ezért választottam én is a tankonyhát. Ha az eredményeket a pedagógiai gyakorlatban később hasznosítani szeretnénk, akkor fontos, hogy ügyeljünk a minél természetesebb környezet kialakítására (Ivanović, 2016). Ezt az elvet figyelembe vettem én is, így a hódmezővásárhelyi intézmény tanulói számára kialakított és jól ismert tankonyha szolgált a kutatás helyszínéül.

\section{A kutatás eszközei}

\section{Eredeti zacskós leves - Dörgicsei csibeleves}

A kutatás megkezdése előtt szükségszerű volt meghatározni azt is, milyen ételt fognak a tanulók elkészíteni: a kerettantervnek megfelelően zacskós levesre volt szükségem. A boltban megvásárolható sokféle zacskós leves szolgált alapsokaságként. Azt, hogy pontosan melyik zacskós levest választottam ki, véletlenszerủ volt. Arra azonban figyeltem, hogy két különböző - egy bögrés és egy túzhelyhasználatot kívánó, edényben készült - zacskós levest válasszak. A két véletlenszerűen kiválasztott darabot elvittem az intézménybe, majd a bevont gyógypedagógusok véleményét kikértem. Ettől a ponttól kezdve szakértői mintaválasztással dőlt el, hogy a két leves közül melyikkel fogunk a továbbiakban dolgozni. A kiválasztás során a gyógypedagógusok korábbi tapasztalataira támaszkodtam, akik figyelembe vették a tanulók képességeit, előzetes ismereteit. A döntésben leginkább az kapott szerepet, hogy a bögrés leves elkészítése finomabb, precízebb mozdulatokat igényel, kisebb eszközökkel kell dolgozni, így ez - a tapasztalatok szerint - nehezebbnek bizonyul. Az imént felsoroltak alapján végül a tűzhelyhasználatot kívánó, edényben készülő Dörgicsei csibeleves mellett döntöttünk.

Meglátásom szerint a Dörgicsei csibeleves zacskóján olvasható leírás egyrészt apró betűs, tehát nehezen olvasható. Másrészt nem elég részletes, az olvasótól/ 
készítőtől előzetes tudást feltételez. Maga az útmutató szorosan az egyéb leírások, reklámok mellett található, így a zsúfoltságtól nehezen lehet tájékozódni a felületen. Bár maga az útmutató valamivel nagyobb betủméretü, mint az oldalon található más leírások, véleményem szerint ez mégsem segíti kellőképpen az egyént. A magyarázat kiegészítéseként szolgáló képek részben felelnek meg a szövegnek. A lényeges lépéseket ugyan bemutatják, de számos egyéb teendő rejtve marad. A dőlt, nem szabályos betűk és számok szintén nehezítik az olvasást, illetve ezáltal a megértést.
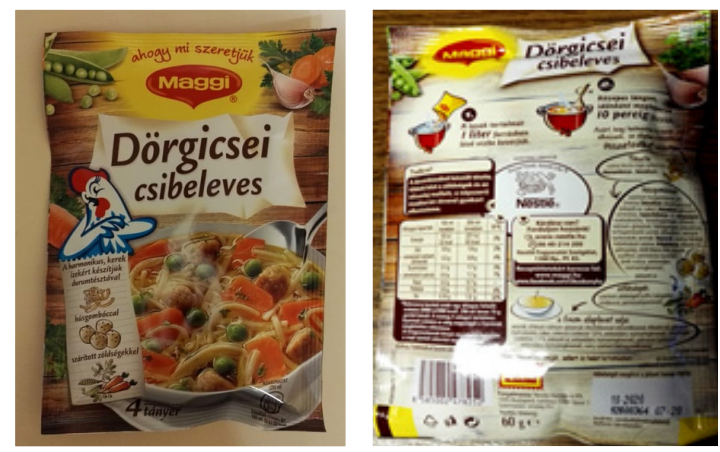

1-2. kép. A zacskós leves tasakjának első és hátsó oldala

\section{Szöveges-képes könnyen érthető recept}

A szöveges-képes receptet magam állítottam össze. A szöveget a könnyen érthető üzenet készítésének írott szabályaira figyelemmel készítettem el. Arial betűtípust, 2-es sorközt használtam. Bár a betủmérettel kapcsolatban a lektorálás során (lásd: lejjebb) erre nem kaptam javaslatot, a 14-es méretet végül 16-ra cseréltem. A címet, illetve az alcímet 18-as betűmérettel, félkövér betűvel készítettem. Az anyagot a könnyebb érthetőség érdekében egészítettem ki képekkel, valamint figyelembe vettem azt is, hogy az eredeti leírásban is látható kép. Az általam készített anyagban található képeket magam fotóztam, valós helyszínen készítettem, abban a tankonyhában, ahol a tanulók a megfigyelés során az ételt ténylegesen elkészítették. Ezt azért tartom kiemelten fontosnak, mert így a tanulóknak nem kell elvonatkoztatniuk a látottaktól, a fotón található konkrét eszközöket kell a fözés során is használniuk. Ez kizárja annak a lehetőségét, hogy a tanulók az absztrakciós képesség hiánya miatt ne tudják a feladatot végrehajtani. Törekedtem továbbá arra is, hogy a képeken ne legyen zavaró háttértényező, kellő megvilágítás legyen, és egyértelmű mozzanatokat ábrázoljak. Fontos szempont volt még, hogy jó minőségủ képek szülessenek, melyek a nyomtatás után is jól láthatóak, elég nagyméretűek. Fokozottan ügyeltem arra is, hogy a nyilak mindig a mutató névmásból kiindulva a megfelelő helyre mutassanak, egyértelműek legyenek.

Munkám során a könnyen érthető kommunikáció egyik fontos alapelvét, a bevonás elvét is követtem (Horváth, 2017a). Az elkészült könnyen érthető anyag érthetőségét az ÉFOÉSZ önérvényesítő munkatársa, Sallai llona (továbbiakban: ellenőr) lektorálta. Az ellenőr számos korábbi tapasztalattal rendelkezik a könnyen érthető üzenetek lektorálása terén, így kellő segítséget tudott nyújtani számomra. Az egyez- 
tetésre nem személyesen, hanem e-mailen került sor: erre a szükös időkeret és a lakóhelyeink közötti nagy távolság miatt volt szükség. Bár úgy gondolom, együttmúködésünk hatékony volt, nem zárkóznék el attól, hogy a későbbiekben a hasonló teendőket személyes úton intézzük, hiszen nyilvánvalóan egyszerübb szóban megfogalmazni - mindkét félnek - a meglátásokat, véleményeket, gondolatokat.

Az ellenőr jelen esetben csak néhány építő kritikát fogalmazott meg, melyeket figyelembe véve a célnak inkább megfelelö, hatékony eszközt tudtam készíteni. Felhívta a figyelmemet például arra, hogy az egyenlőségjelet cseréljem ki a „vagyis” kifejezésre, illetve megkért, hogy néhány helyen a folyamatot bontsam tovább, és ennek megfelelően több lépésben ábrázoljam azt (konkrétan: „Tedd az edényt a túzhelyre.” „Vedd le az edényt a túzhelyröl.”).

A szöveges-képes könnyen érthető receptet az 1. számú mellékletben csatolom.

\section{Képes könnyen érthető recept}

A kutatás során felmerülő nehézségek miatt (lásd: A kutatás tényleges előkészítése című alfejezet) szükségessé vált a nem olvasó tanulók számára a szöveg nélküli, képes könnyen érthető recept elkészítése.

A csak képes folyamat-ábrázolás készítése során ugyanazokat az elveket, szabályokat vettem figyelembe, mint amelyeket a szöveges-képes változat készítésekor, és ugyanazokat a képeket használtam mind a két verzióban. Ezen anyag készítése közben még inkább bebizonyosodott számomra, milyen fontos, hogy konkrét képeket használjak, hiszen egyetlen kép alapján a tanulónak fel kell ismernie, milyen cselekvést várok el töle. Az eszközöket és az elkészítési folyamatot ábrázoló képeket sorszámokkal jelöltem. Ügyeltem arra, hogy ez a két csoport jól elkülöníthető, könnyen értelmezhető legyen, így a nyomtatott változatban egy piros lapot tettem közéjük.

Az ellenőr a képes könnyen érthető recept esetében nem tett javaslatot, kiegészítést.

\section{Szöveges-képes leírás a csap használatához}

A kutatás elökészítése során felmerült a kérdés, mi történik, akkor, ha a tanuló nem tudja használni a tankonyhában található csapot? Ennek okán készült el a szöveges-képes leírás, mely a csap használatát magyarázza. A szöveget szintén a könynyen érthetö üzenet készítésének szabályai alapján írtam. Arial betūtípust, 2-es sorközt, a korábbi 14-es helyett 16 -os betüméretet használtam. Az ellenőr javaslatára címet adtam az anyagnak, melyet 18-as betűmérettel, félkövér betűvel készítettem. Ugyanúgy, ahogy a receptnél, itt is a valós helyszínen, a megfigyelésnek helyet adó tankonyhában készítettem fotókat, melyekkel a könnyen érthető szöveget kiegészítettem. A fotókra vonatkozó, előzetesen ismertetett szabályok betartása ez alkalommal is megvalósult. Jelen esetben is törekedtem arra, hogy a mutató névmásból kiindulva, egyértelmű nyilakkal magyarázzak. A nyitás és a zárás mozdulatának irányát nyilakkal is szemléltettem.

Az ellenőr javaslatára a „Fogd meg a csapot.” mondat helyett a „Fogd meg a csap karját.” leírás szerepel a végleges változatban. Állítása szerint jobban értelmezhető a mondandóm, ha konkrétumot írok, mert neki a csap szóról az egész csap jut eszébe. Mivel jogosnak tartottam a meglátását, természetesen javítottam. Ugyanezt a ja- 
vítást megtettem az „Emeld fel a csapot.”, valamint a „Nyomd le a csapot.” mondatnál is. Az ellenőr további javaslata az volt, hogy jelenjen meg az is: nem csak az általam bemutatott csapfajta létezik. Ennek megfelelően kiegészítést tettem arra vonatkozóan is, hogy ugyan többféle csap létezik, de én most ezt a fajta csapot mutatom be. Az ellenőr véleménye szerint célszerű lett volna bemutatni a víz hőfokának a szabályozását is. Tekintve azt, hogy konkrét, általam ismert értelmileg akadályozott személyek számára készült a leírás, úgy gondoltam, ez a magyarázat bonyolította volna annak a cselekvésnek a megértését, melyet elvártam a tanulóktól. Jelen helyzetben nem volt célom magyarázni azt, hogyan kell a víz hőfokát szabályozni, így az erre vonatkozó javaslatot nem fogadtam meg.

Itt szeretném megemlíteni azt, hogy bár az ellenőr nagyon sok segítséget nyújtott a munkám során, az ő képességei nem tükrözik azoknak a személyeknek a képességeit, akikkel a kutatási folyamatban dolgoztam. Hasznosnak tartanám, ha lehetőség lenne arra, hogy különböző nyelvi és kognitív képességekkel rendelkező lektorokkal tudjunk dolgozni, hiszen így biztosítható leginkább az ellenőrzés hatékonysága.

A csap használatának szöveges-képes leírását a 2. számú mellékletben csatolom.

\section{Képes leírás a csap használatához}

Annak tudatában, hogy a részt vevő 8-ból 4 tanuló nem olvas (lásd: A kutatás tényleges előkészítése című alfejezet), ez esetben is szükségszerű volt a csap használatának csak képekkel való bemutatása.

Ennek az anyagnak az elkészítése közben is a szöveges-képes változatban használt, a kísérlet helyszínén általam készített képeket alkalmaztam. Törekedtem arra, hogy minél egyértelműbb mozzanatokat mutassak be, így csupán három képben magyaráztam a csap használatát. Az általam végzett és a tanulóktól elvárt mozdulat irányát nyilakkal is szemléltettem. A képes leírás az imént bemutatott szöveges-képes leírással megegyezik, a különbség a szöveg meglétében van.

\section{Pedagógiai Analízis és Curriculum}

A kutatási folyamatban a Günzburg által kifejlesztett Pedagógiai Analízis és Curriculum (P-A-C) felmérő eszközt terveztem még alkalmazni. A P-A-C lehetővé teszi a meglévő és hiányzó készségek felmérését, láthatjuk a viselkedés gyengeségeit és erősségeit. „A P-A-C eljárás célja, hogy minőségi képet nyújtson a szociális kompetencia erősségeiről és gyengéiről, szemben a mennyiségben kifejezett teszt ponttal (Günzburg, 2000:18). A pedagógiai diagnosztikai eszköz négy területet mér fel - az önkiszolgálást, a kommunikációt, a szocializációt és a tevékenységet. A felsorolt területek közül a kommunikációra vonatkozó itemek eredményeit állt szándékomban felhasználni a megfigyelési szakaszba kerülő tanulók kiválasztására. Így a vizsgálatba eredetileg bevonni tervezett 20 föből tudtam volna kiválasztani olyan 10 föt, akiknek közel azonos a nyelvi kompetenciája. Ezzel kizárhattam volna azt, hogy a kétféle szövegtípus megértése közötti különbséget a tanulók eltérő nyelvi kompetenciájával lehessen magyarázni. 


\section{Interjú-kérdéssor}

A tanulók zacskós leveshez, illetve a konyhai munkához kapcsolódó előzetes tudását is szerettem volna feltérképezni. A főzési folyamat során alkalmazott eredeti leírás és a könnyen érthető leírás értelmezését ugyanis befolyásolhatja az előzetes tudás és előzetes tapasztalat is. Szerettem volna kizárni ezt a változót is. A cél az volt, hogy közel azonos elözetes tudással és elözetes tapasztalattal rendelkező tanulót választhassak be a megfigyelési helyzetbe. Ennek érdekében készítettem el egy interjú-kérdéssort, melyet a tanulókkal foglalkozó gyógypedagógusokkal állt szándékomban feltenni. Meg szerettem volna tudni, hogy a tanuló készített-e már korábban zacskós levest; ha igen, akkor milyen eredményességgel, illetve ez otthon vagy az iskolában történt.

A kérdések megfogalmazása során törekedtem arra, hogy minél több információt megtudjak a tanuló ételkészítéshez való hozzáállásáról, tapasztalatairól, tudásáról. Fontosnak tartottam továbbá, hogy információt gyűjtsek a tanuló kommunikációjáról, így ezzel kapcsolatban is fogalmaztam meg kérdéseket. Ez többek között segítséget nyújtott abban, hogy megállapítsam, a tanulónak a szöveges-képes vagy a képes könnyen érthető anyagra lesz szüksége a megfigyelés során.

Fontos megjegyezni, hogy tisztában voltam azzal, a tervezett interjú során kapott információ nem feltétlenül megbízható, hiszen előfordulhat, hogy a tanuló bár többször is készít otthon ételt, erről nem számol be az iskolában.

\section{Megfigyelési szempontok}

A kutatás előkészítése során szándékomban állt a gyógypedagógus irányítása alatt a zacskós leves elkészítését megfigyelni az érintett tanulók körében. Ezt azért tartottam volna szükségesnek, mert szerettem volna a nem a „receptek" értelmezésböl következő, de a fözési folyamatot befolyásoló tényezőket kizárni (például a cselekvések kivitelezésével kapcsolatos problémákat).

A megfigyelési szempontok megfogalmazása során kiemelten figyeltem arra, hogy magára a zacskós leves elkészítésére, a tanuló hozzáállására, tudására fókuszáljak. Szerettem volna információt gyűjteni arról, hogy a gyógypedagógus jelenléte, a társak jelenléte, esetleg a magam mint kívüláló jelenléte mennyire befolyásolhatja a munkát. Ezen információk birtokában reálisabban láthattam volna a tanuló megfigyelés során tanúsított magatartását, megfigyelhettem volna, hogy a tanuló milyen szintű motiválást igényel, egyáltalán igényel-e. A megfigyeléseim lejegyzéséhez egy táblázatot is készítettem.

\section{Utasítások}

A tanári magyarázatból nyert információ is befolyásolhatja a különböző „receptek” értelmezését. Ezt is szerettem volna kizárni. Ezért előzetesen készítettem egy „utasítás-leírást", amelyben azt fogalmaztam meg, amit minden, a megfigyelési helyzetbe kerülő gyermeknek azonos módon mondtam. Ötféle utasítást készítettem el - az eredeti szöveghez, a szöveges-képes könnyen érthetö recepthez, a képes könnyen érthető recepthez, a csap használatának szöveges képes leírásához, a csap használatának képes bemutatásához. Törekedtem arra, hogy a lényegre koncentrálva 
egyszerüen és pontosan fogalmazzak. A séma valamennyi alkalommal ugyanaz volt, csupán néhány változtatást tettem annak megfelelően, hogy melyik folyamatról áll szándékomban instrukciót adni.

Itt szeretném még megemlíteni, hogy a megfigyelési helyzetben nem volt célom azt is felmérni, hogy a tanuló tájékozódik-e a konyhában, megtalálja-e a szükséges eszközöket, ezért minden használatos eszközt a megfigyelés megkezdése előtt a pultra készítettem.

\section{Kutatásetikai megfontolások}

A kutatás céljáról és annak folyamatáról minden érintett szereplő számára készítettem tájékoztató leveleket, az értelmileg akadályozott tanulók számára könnyen érthetően. A kutatás során nyert adatok és információk felhasználhatósága érdekében adatkezelési hozzájáruló nyilatkozat is készült, amit a szülők írtak alá. A tanulók is hozzájárultak ehhez könnyen érthető nyilatkozat formájában.

\section{A kutatás tényleges elökészitését befolyásoló tényezők}

A hódmezővásárhelyi Kozmutza Flóra Óvoda, Általános Iskola, Szakiskola, Kollégium, Egységes Gyógypedagógiai Módszertani Intézmény vezetőjével vettem fel elsőként e-mailen a kapcsolatot. Miután pozitív választ kaptam, megbeszéltünk egy személyes találkozót, melynek során részletesen ismertettem a kutatásomat. Erre az alkalomra magammal vittem valamennyi tájékoztató levelet, illetve hozzájáruló nyilatkozatot és kértem, juttassa el az illetékeseknek.

A kvalitatív kutatások esetében a kutatás alanyaihoz való hozzáférés igen nehéz és időigényes munkafolyamat (Sántha, 2009). A szakértői mintaválasztáshoz szükséges mérések elvégezhetősége érdekében az alapsokaságot jelentő mind a 20 tanuló szülője számára megküldtem a tájékoztató levelet és az adatkezelési hozzájáruló nyilatkozatot. A várakozásokkal ellentétben a 20 helyett mindössze 8 szülő hozzájáruló nyilatkozata érkezett vissza. Így a szakértői mintaválasztás meghiúsult. Bár P-A-C teszt eredményei rendelkezésemre álltak, végül azokat sem használtam. A 8 fős csoportot már nem lehetett tovább szűkíteni. Így mind a 8 főt bevontam a kutatásba: három hetedik, két nyolcadik, egy kilencedik és két tizedik osztályos tanulót, három lányt és öt fiút.

Miután kézhez kaptam a hozzájáruló nyilatkozatokat, felkerestem az érintett gyógypedagógusokat. Praktikus okokból a félig strukturált interjú helyett a gyógypedagógusok írásban válaszoltak a kérdéssorra.

Figyelemmel arra, hogy a főzési folyamat megfigyelésére kiválasztott osztályokban a kutatási időszakban a zacskós leves készítése nem szerepelt a kerettanterv alapján a gyógypedagógusok által készített tematikus tervben, ezért végül a gyógypedagógus irányítása alatt a zacskós leves elkészítésének megfigyelésére sem volt lehetőségem.

Azt, hogy az első megfigyelésre mikor kerül sor, e-mailen egyeztettem a gyógypedagógusokkal. Az alkalmakat a tanítási időre beszéltük meg. Egy tanulóra egy órát szántam, így négy tanulót osztottam be egy napra. Végül ez az első főzés alkalmával két tanuló betegsége miatt három napra bővült. A második alkalommal hasonló okok miatt, szintén három nap leforgása alatt zajlott a főzési folyamat megfigyelése. 
Egy újabb módosítást tettem a megfigyelés rögzítésére vonatkozóan is. A kutatás tervezésekor szándékom az volt, egy állványon fog állni a mobiltelefon, mellyel a videofelvételt rögzítem. Késöbb felmerült, hogy ha a kamera egy ponton áll, kimaradhatnak fontos mozzanatok, ha a tanuló kilép a kamera látószögéből, a részletek - mimika, az ujj vezetése a recepten - nem látszódhatnak. Mindennek okán úgy döntöttem, egy kívülálló személyt vonok be, aki az eseményeket majd rögzíteni fogja. Mivel az öcsémnek van tapasztalata a felvételek készítésében, így egyértelmü volt számomra, hogy őt kérem fel erre a feladatra. Miután vele ezt megbeszéltem, e-mailen jeleztem az intézményvezető asszonynak - akit egyébként folyamatosan tájékoztattam a kutatás állásáról - és a gyógypedagógusoknak változtatási szándékomat. Valamennyien beleegyezésüket adták.

Mivel a szelektálás hiányában nem tudtam azonos nyelvi kompetenciával, hasonló előzetes ismerettel és tapasztalattal rendelkező tanulót kiválasztani, így újabb változtatást tettem. Tekintettel arra, hogy a 8-ból 4 tanuló rendelkezett csak az olvasás képességével, 4 tanuló pedig nem, így vált szükségessé a képes könnyen érthető recept elkészítése is. Ezen a ponton merült fel a csap használatának kérdése is, melynek kapcsán - bár az előzetes tervek között nem szerepelt - elkészítettem a könnyen érthető szöveges-képes és a képes leírásokat.

\section{Módosítások a kísérlet első alkalma után}

Nem titkolt tervem volt, hogy az általam készített könnyen érthető anyagok érthetöségét, hatékonyságát az első főzési alkalmon látott tapasztalataim alapján összegyűjtsem. Egy azonnal szembeötlő problémát valamennyi tanuló esetében érzékeltem. Ez nem volt más, mint hogy az általam kialakított könnyen érthető receptben elöbb szerepelt a leves kevergetése, mint az óra beállítása 10 percre. Ez azt eredményezte, hogy az információnak megfelelően a tanuló elkezdte kevergetni a levest, ám így nem tért át a következő lépésre, és nem teljesítette azt. Így a második főzési alkalomra a két utasítást felcseréltem. Minden tanuló esetében azt tapasztaltam, hogy így gördülékenyebben tudtak egyik lépésről a másikra áttérni.

\section{Megjegyzések}

A megfigyelési helyzetek tapasztalatai alapján fontosnak tartom rögzíteni az alábbiakat.

A könnyen érthető receptek leírásában nem szerepelt, hogy pontosan meddig kell tölteni a vizet az üvegbe. Bár erre vonatkozólag nem tettem módosítást, azt gondolom, ezen célszerủ lenne a jövőben változtatni.

A szöveges-képes könnyen érthető anyagok esetében többször tapasztaltam, hogy a szöveg inkább hátráltat, mint segít. Sokszor előbb nézték meg a tanulók a képeket, az azokon szereplő információ sokszor elegendő is lett volna a tevékenységükhöz.

A szelektálás hiányában különböző képességű tanulók vettek részt a főzési folyamatban. És ez meg is mutatkozott az eltérő főzési teljesítményben, vélhetően az olvasási készség függvényében.

Többször előfordult a zacskó nyitásának nehézsége, mely a legtöbb esetben a finommotorika fejletlenségéből adódott. Több alkalommal nehézséget okozott a könynyen érthető receptről készített füzetben történő lapozás is. 
Ugyanakkor valamennyi tanuló nagyon készségesen állt rendelkezésemre, utasításaimnak eleget téve gördülékenyen tudtunk együtt dolgozni. Azt gondolom, az ő támogató hozzáállásuk nélkül e tanulmány nem jöhetett volna létre.

\section{ÖsSzegzés}

Kutatásom során arra vállalkoztam, hogy egy könnyen érthetőnek és olvashatónak szánt anyag érthetőségét összevetem egy eredeti, zacskós levesen található elkészítési útmutató leírásának érthetőségével. Munkám során arra a kérdésre kerestem a választ, hogy az értelmileg akadályozott személyek valóban könnyebben értik-e meg a könnyen érthetőnek és olvashatónak szánt, tudatosan kialakított anyagot, mint az - elsősorban a normál fejlődésmenetű személyeknek szánt - eredeti verziót?

Ebben a tanulmányban az elvégzett kutatás módszertanát, az általam készített könnyen érthető anyagokat mutattam be. Az eredményeket Svájcban, a második „Könnyen Érthető Nyelvhasználat Kutatása” konferencián publikálom 2021. augusztus 30-31-én poszter formájában.

\section{Irodalom}

a Fogyatékossággal élő személyek jogairól szóló ENSZ egyezmény, 2006

Boncz I. (2015), Kutatásmódszertani alapismeretek. Pécsi Tudományegyetem Egészségtudományi Kar, Pécs. https://www.etk.pte.hu/protected/OktatasiAnyagok/\%21Palyazati/ sport/Kutatasmodszertan_e.pdf Letöltés ideje: 2020.01.24.

Farkasné Gönczi R. \& Graf-Jaksa É. (2009). Könnyen érthető kommunikáció. In Pandula A., Szatmári P., Vincze T., Farkasné Gönczi R. \& Gráf-Jaksa É. (szerk.), Kommunikációs és információs technológiák és fogyatékosságügy. ELTE Bárczi Gusztáv Gyógypedagógiai Kar, Budapest. 80-100.

Farkasné Gönczi R. (2018). A könnyen érthető kommunikáció fogalma és szabályrendszere nemzetközi és hazai példák, illetve magyar tapasztalati szakértők javaslatai alapján. Gyógypedagógiai Szemle, 46.1:64-76.

Farkasné Gönczi R. (2019). Könnyen érthető kommunikáció - Könnyen érthető élet. http://konynyenertheto.gonczirita.hu/ Letöltés ideje: 2019.12.28.

Günzburg, H. C. (2000). Pedagógiai Analízis és Curriculum a szociális és személyiségfejlődés mérésére értelmi fogyatékos személyeknél. ELTE Bárczi Gusztáv Gyógypedagógiai Főiskolai Kar, Budapest.

Hatos Gy. (2015). Az értelmi akadályozottság értelmezésének változásai. Pedagógiatörténeti Szem/e, 1.1:1-11. http://www.jgypk.hu/pedtort/wp-content/uploads/2014/12/2015_01. pdf Letöltés ideje: 2020.01.29.

Horváth P. L. (2017a). Érthető számodra a világ? Ha nem, tedd érthetőbbé! Carissimi, VIII.5:810.

Horváth P. L. (2017b). Önrendelkezés és könnyen érthető kommunikáció - a KÉK hazai fejlesztésének lehetőségei. In Bogdán B., Cserti-Szauer Cs., Katona V. \& Sándor A. (szerk.), Befogadás és önrendelkezés. Absztraktkötet. ELTE Bárczi Gusztáv Gyógypedagógiai Kar, Budapest. 23-27.

Olvasás-írás kerettanterv a középsúlyosan értelmi fogyatékos tanulók számára 1-8. évfolyam (2020). https://www.oktatas.hu/pub_bin/dload/kozoktatas/kerettanterv/ksni_1_8/Olvasas-iras.doc Letöltés ideje: 2021.03.2.2.

Sántha K. (2009). Bevezetés a kvalitatív pedagógiai kutatás módszertanába. Eötvös József Könyvkiadó, Budapest.

Sutherland, R. J. \& Isherwood, T. (2016). The Evidence for Easy-Read for People With Intellectual Disabilities: A Systematic Literature Review. Journal of Policy and Practice in Intellectual Disabilites, 13.4:297-310. https://doi.org/10.1111/jppi.12201

Szebelédi-Kurucz A. (2012). Farkasné Gönczi Rita: Könnyen érthető konyha. Gyógypedagógiai Szemle, 40.3:286. 


\section{SZÁMÚ MELLÉKLET}

\section{SZÖVEGES-KÉPES KÖNNYEN ÉRTHETŐ RECEPT}

\section{LEVESRECEPT}

HOZZÁVALÓK

1 zacskós levespor

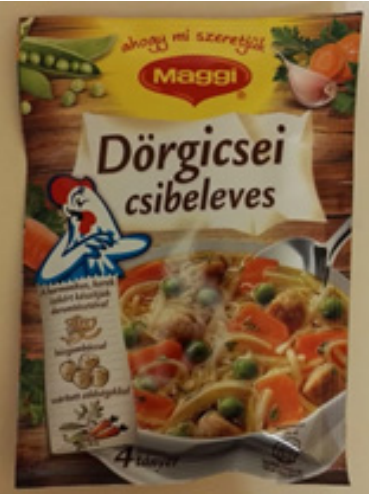

1 liter víz vagyis 1 üveg víz

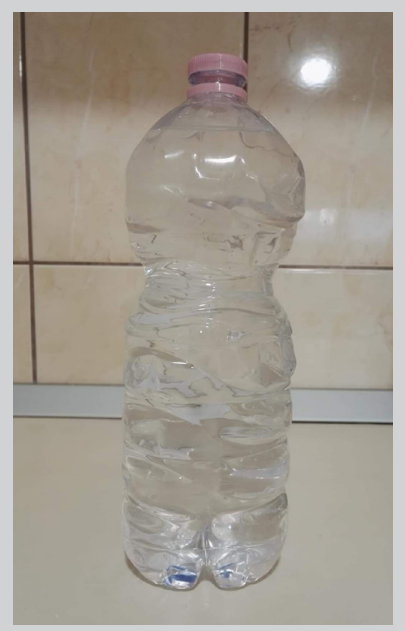


Edény

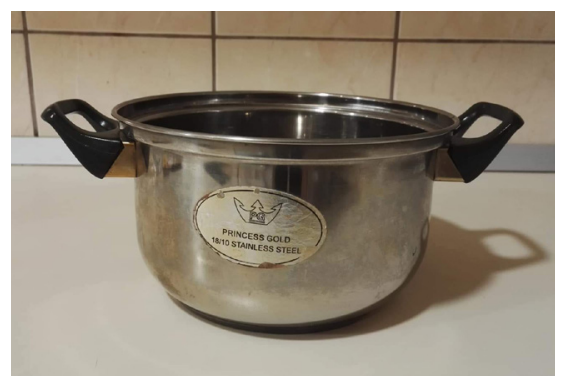

Fakanál

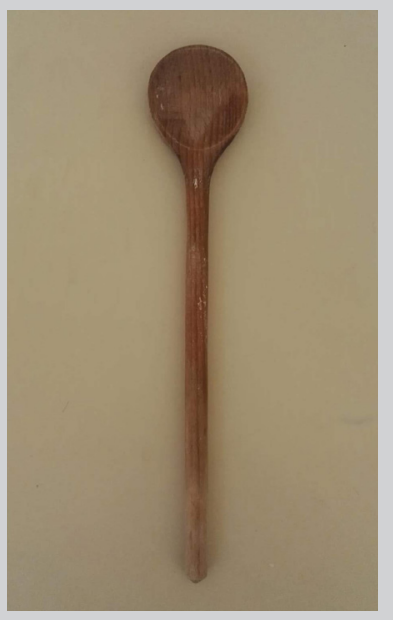

\section{ELKÉSZÍTÉS}

1. Vegyél elő egy edényt.

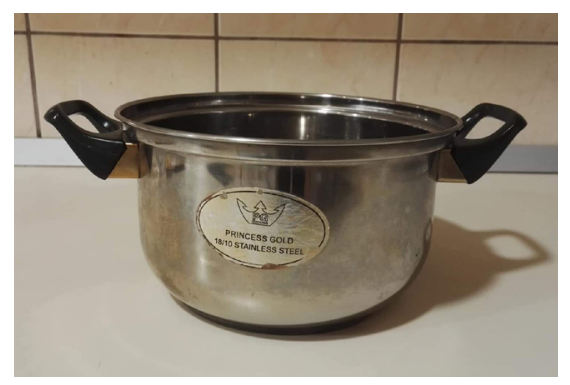


2. Vegyél elő egy üveget.

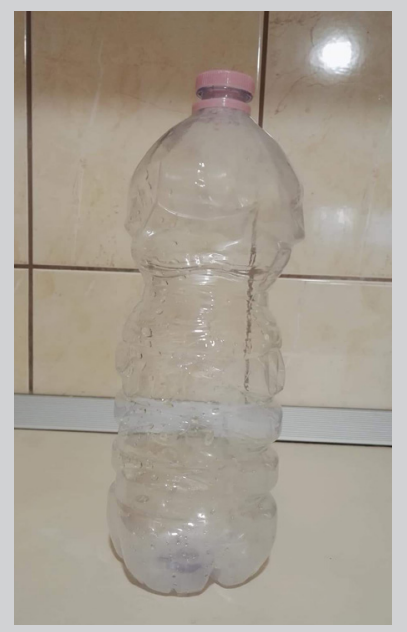

3. Az üveget töltsd meg vízzel.
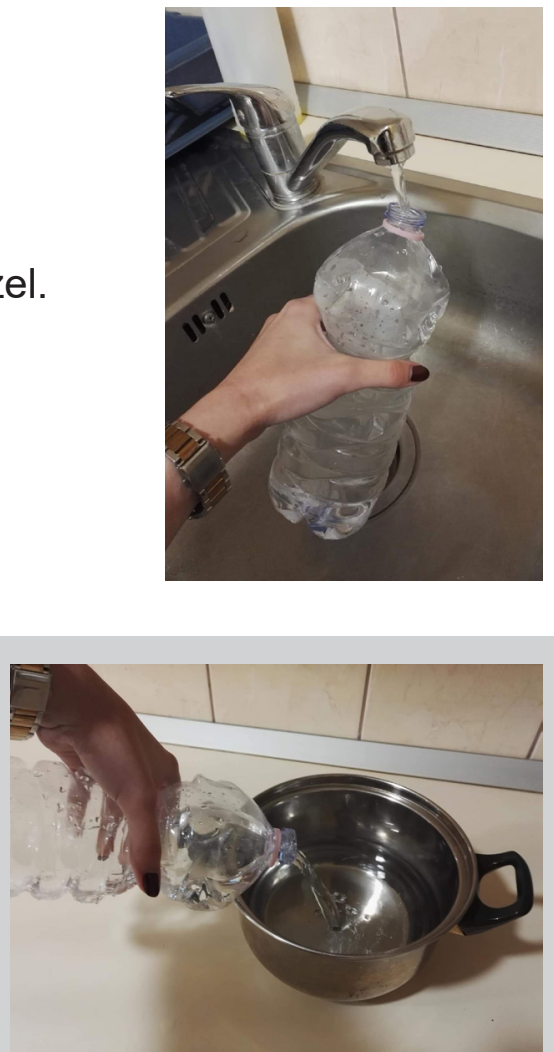

4. A vizet öntsd bele az edénybe. 
5. Ez a tüzhely.

A tüzhelyen főzöl.

A tüzhelyet be kell kapcsolni.

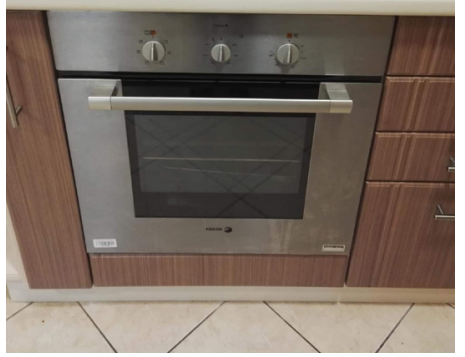

6. A falon van egy csap. A csap így néz ki.

7. Fogd meg a csapot.

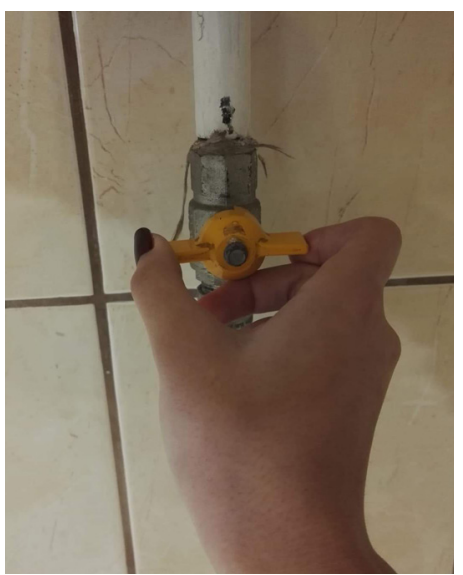


8. Tekerd a csapot lefelé.

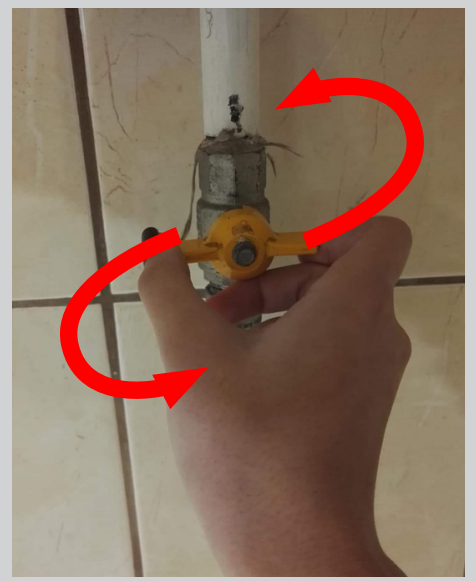

9. Most így néz ki a csap.
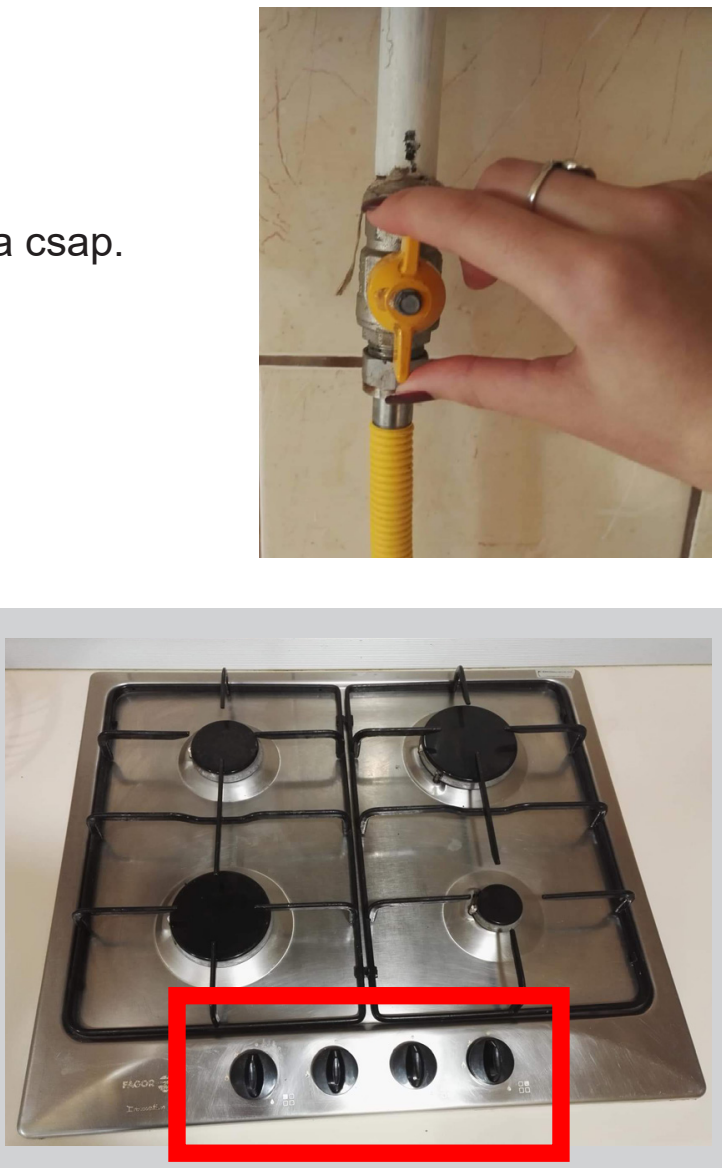

10. A tüzhelyen vannak gombok. 


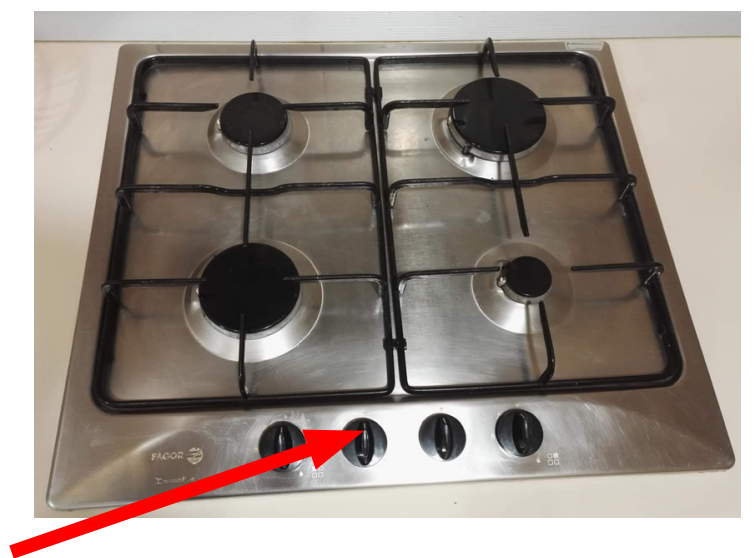

11. Te ezt a gombot használod.

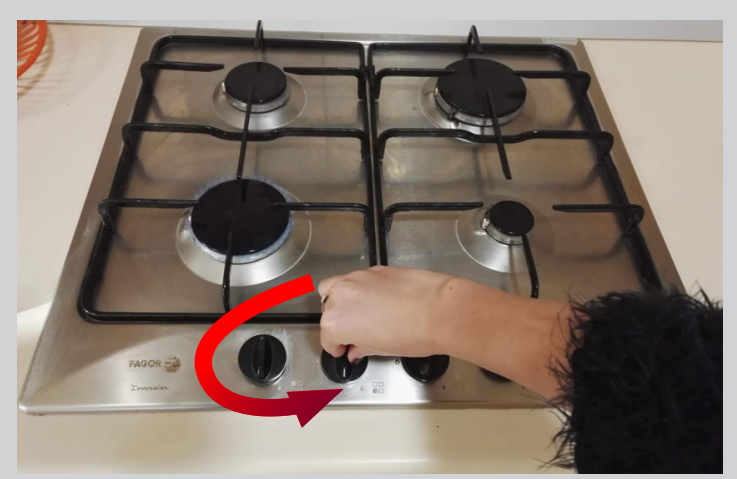

12. Nyomd le a gombot.

Tekerd a gombot lefelé.

13. Most így néz ki a gomb.

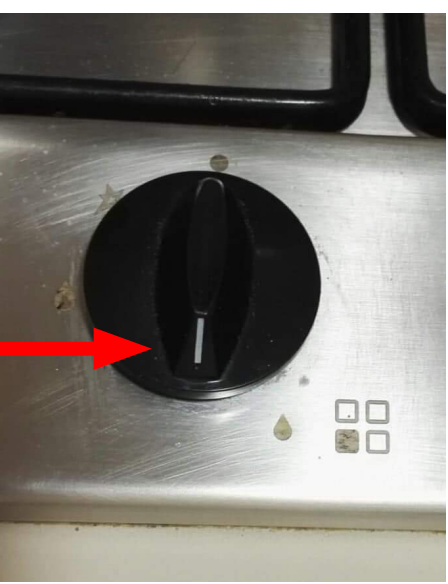


14. Bekapcsoltad a tüzhelyet.
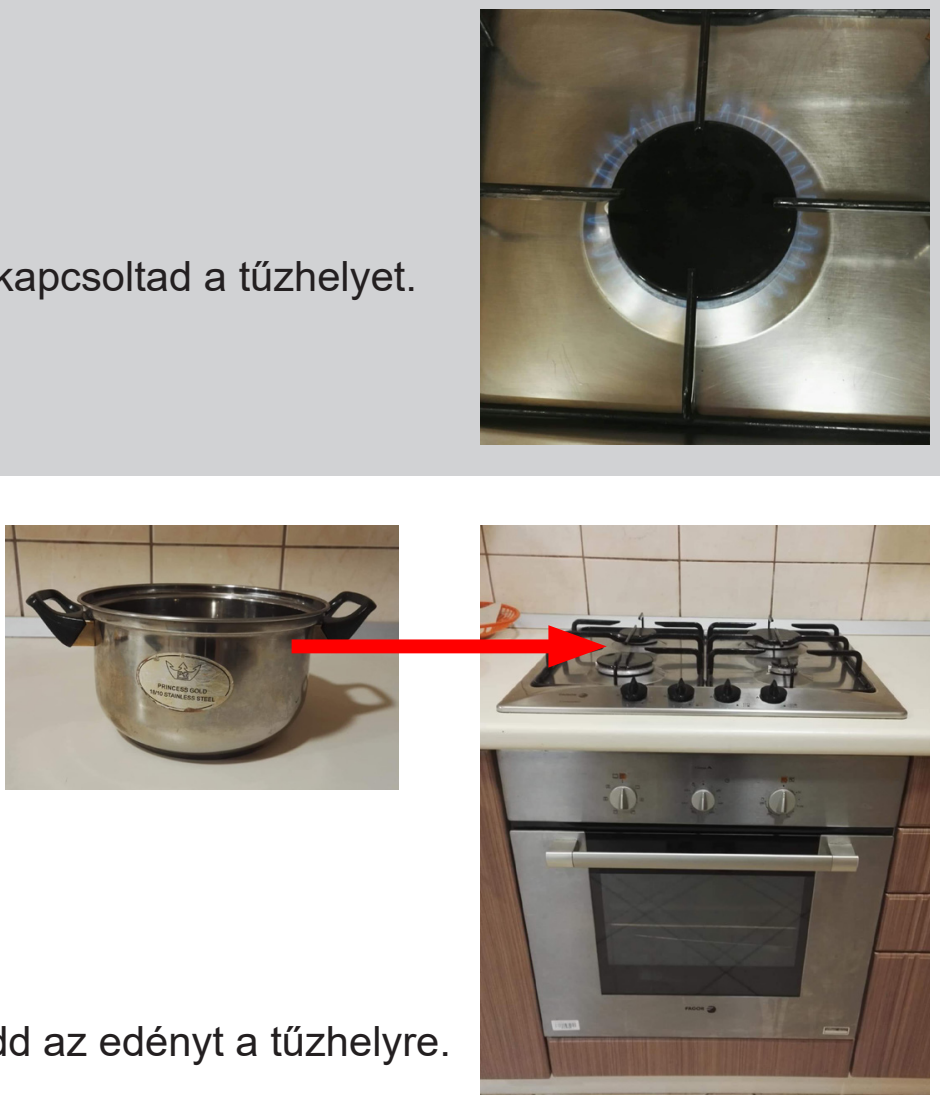

15. Tedd az edényt a tűzhelyre.

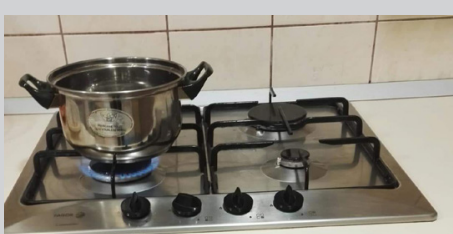

16. Az edény a tủzhelyen van.

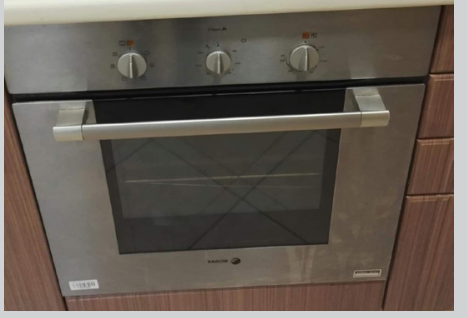


17. Várj, amíg felforr a víz. A felforrás azt jelenti, hogy a víz bugyogni kezd.

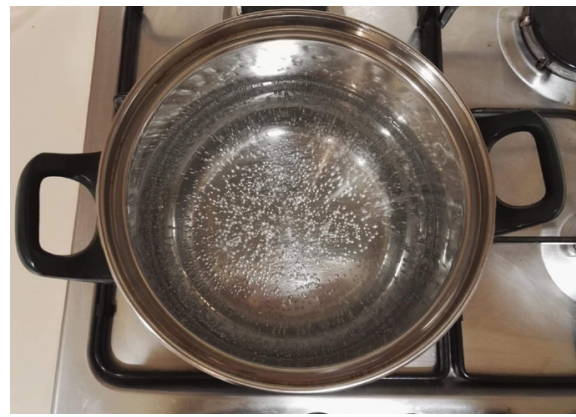

18. Felforrt a víz.

Tépd le a zacskó tetejét.

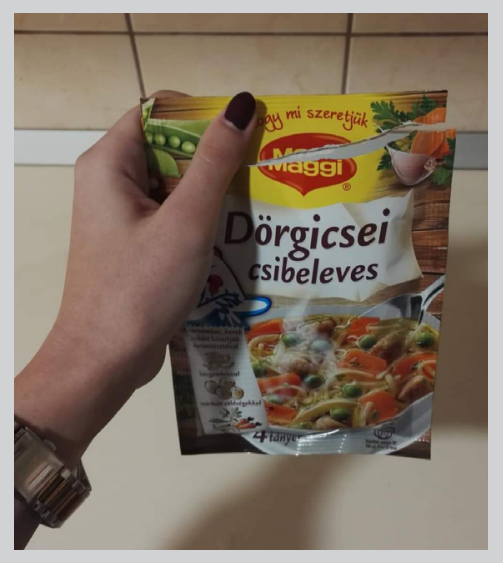

19. A zacskóban levespor van.

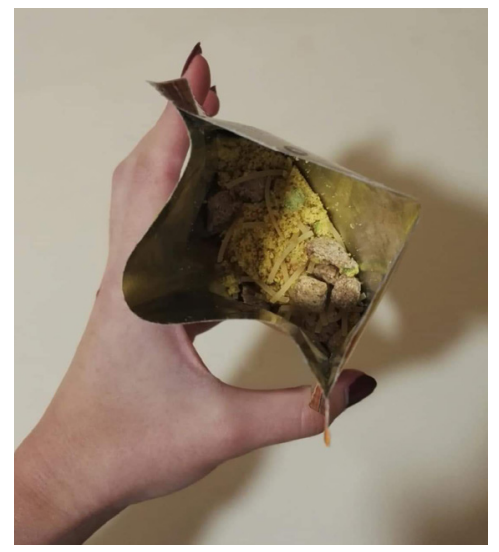


20. Öntsd a levesport az edénybe.

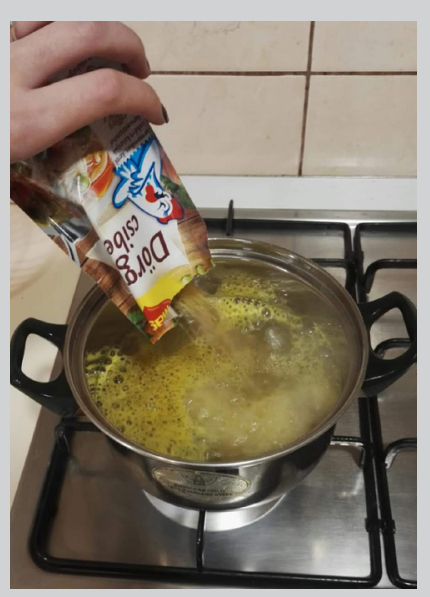

21. 10 percig főzd a levest.
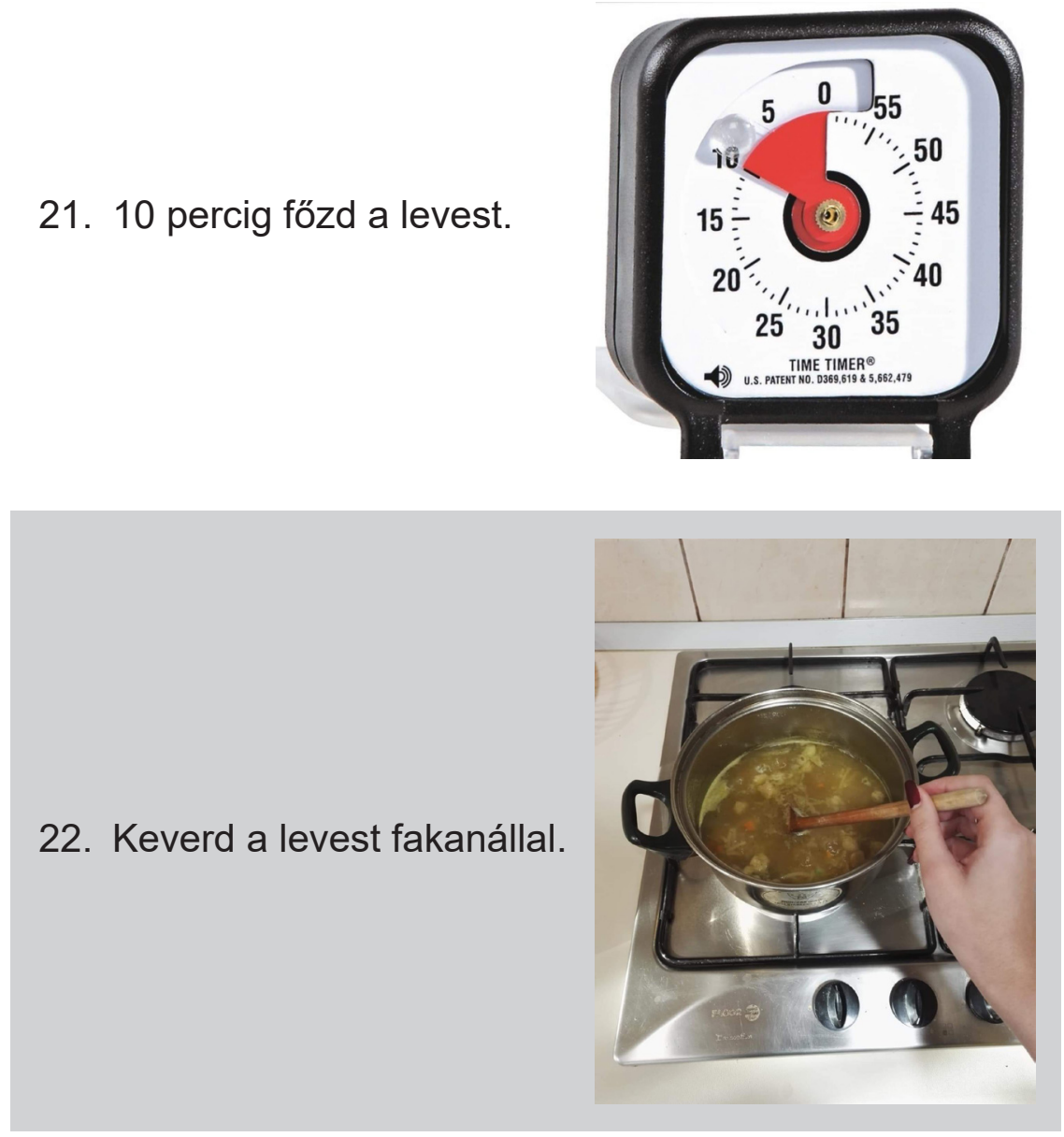
23. A 10 perc eltelt.

Vedd le az edényt a tüzhelyröl.

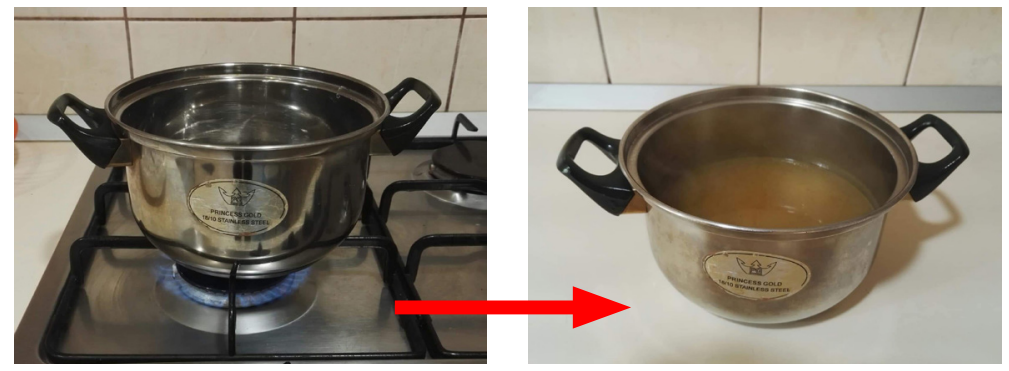

24. Az edényt levetted a tüzhelyröl.

Kész a leves.

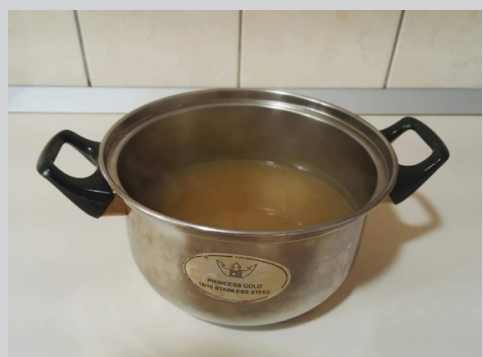

25. Zárd el a tủzhelyet.

Nyomd le a gombot.

Tekerd a gombot felfelé.

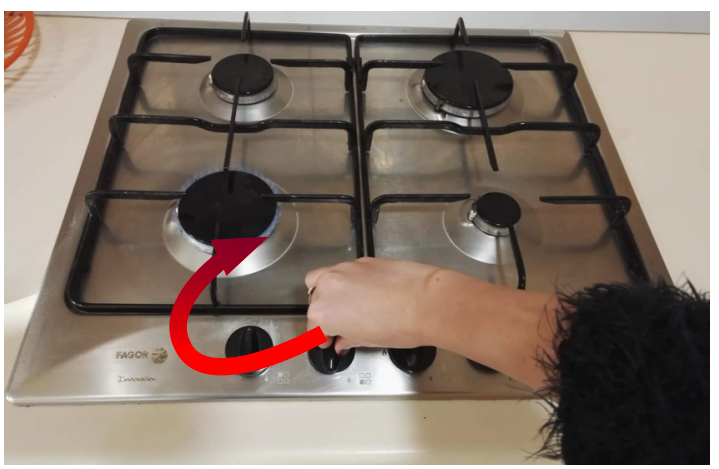




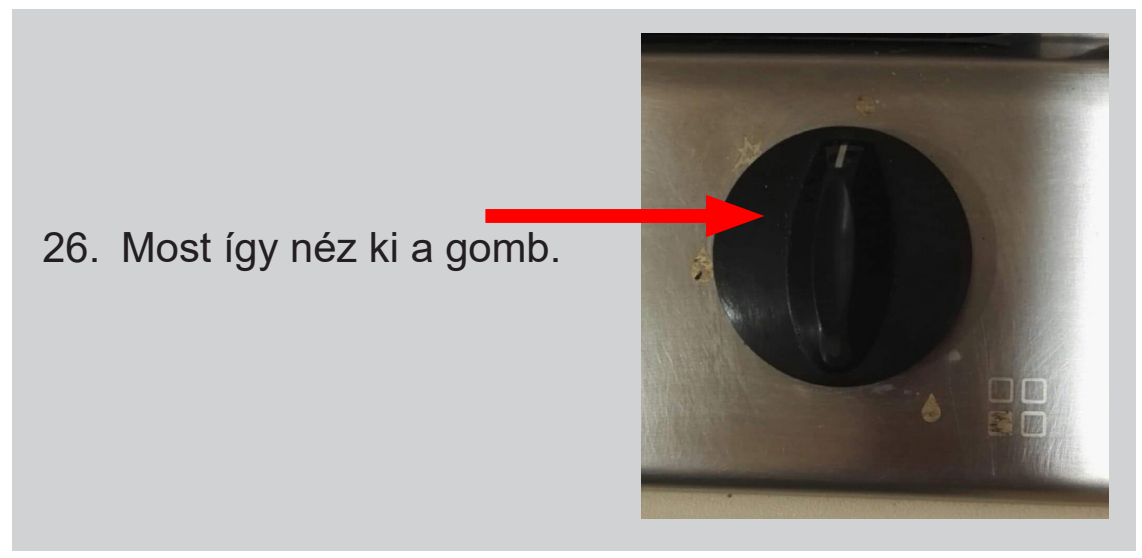

27. Elzártad a tűzhelyet.
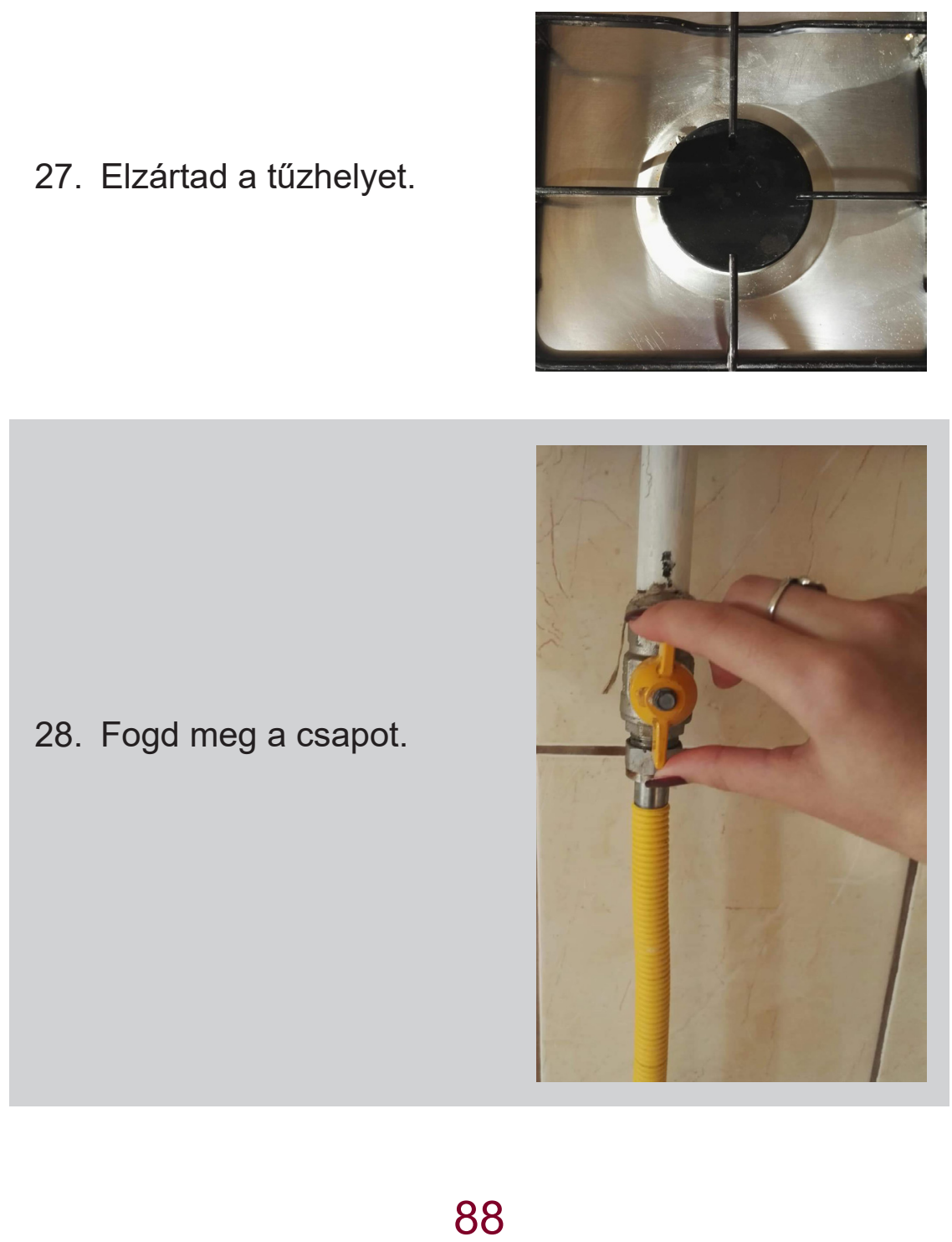
29. Tekerd a csapot felfelé.

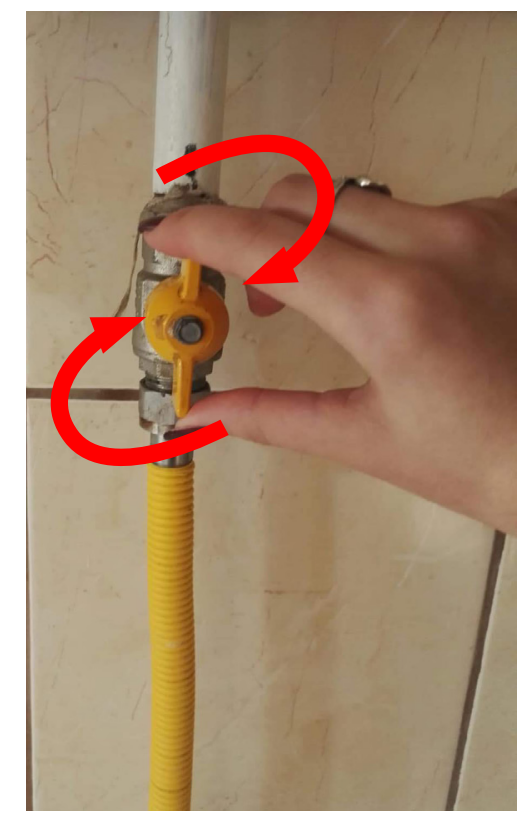

30. Elzártad a csapot.

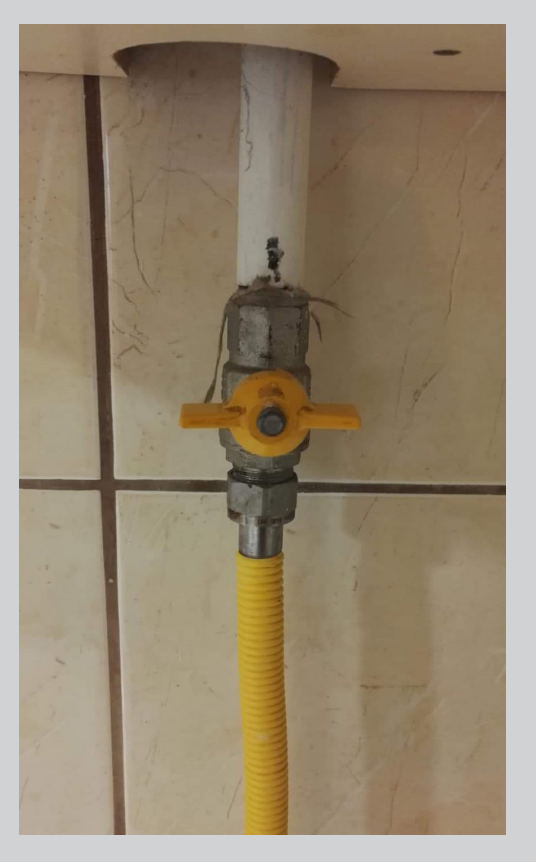




\section{SZÁMÚ MELLÉKLET}

\section{A CSAP HASZNÁLATÁNAK SZÖVEGES-KÉPES LEÍRÁSA}

CSAP HASZNÁLATA

Ez a mosogató.
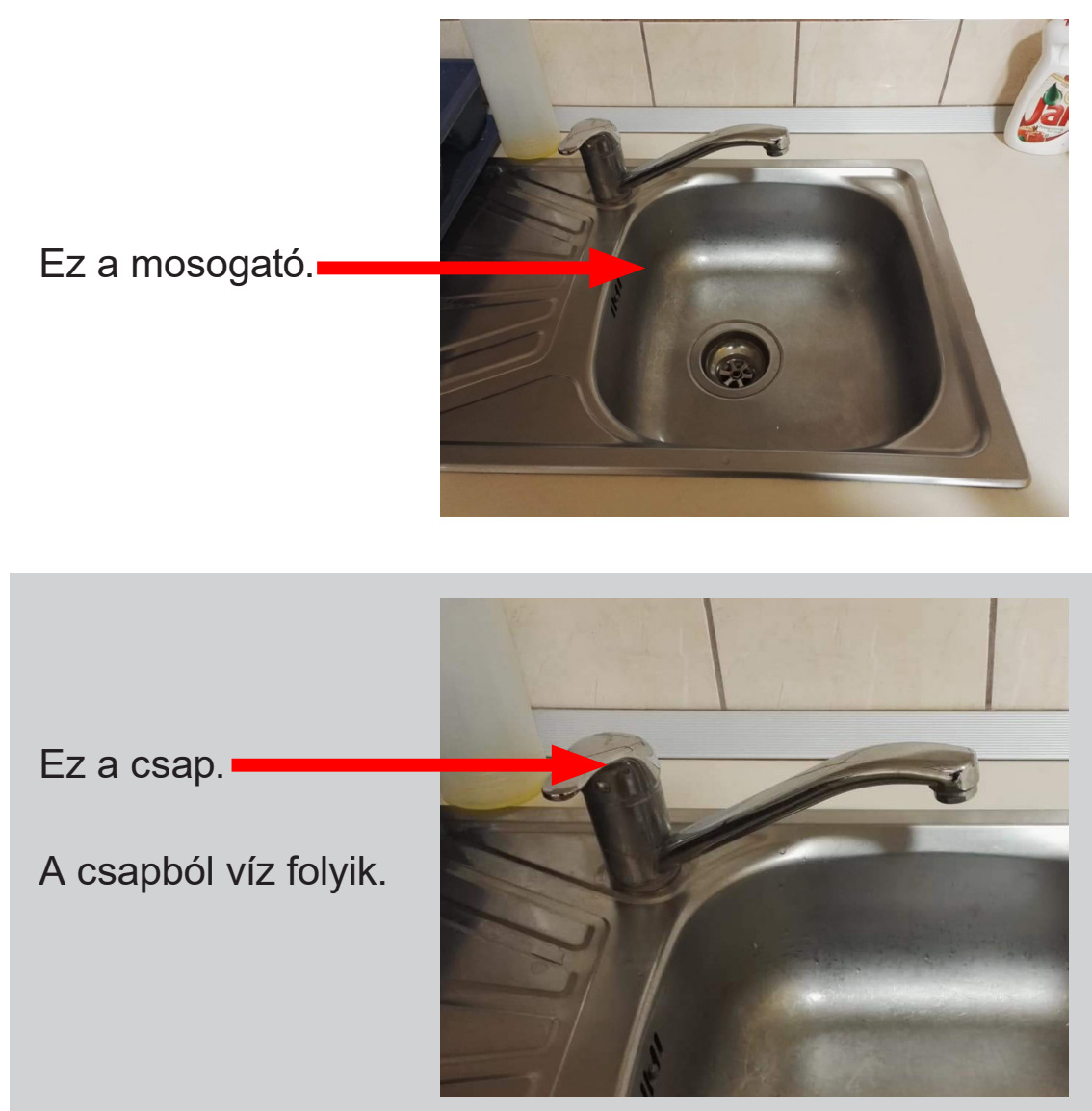
Sokféle csap van.

Én ezt a csapot mutatom meg.

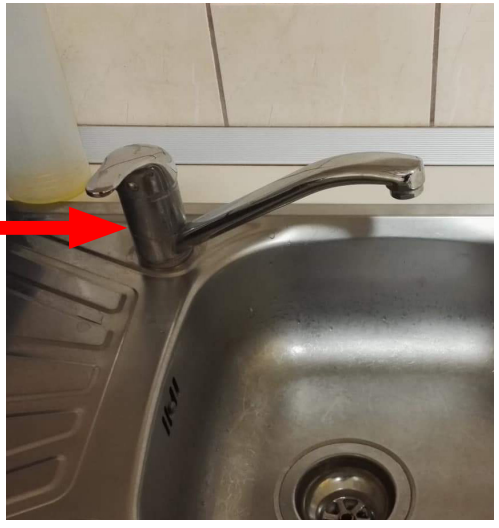

Fogd meg a csap karját.

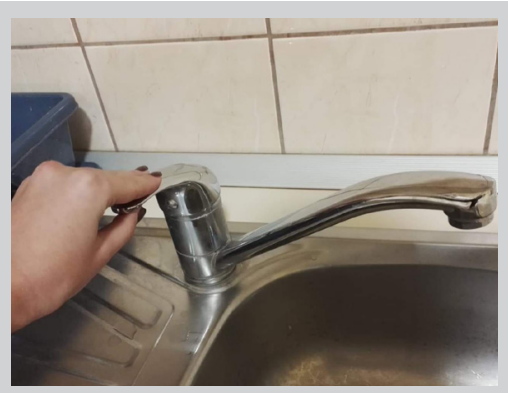

Emeld fel a csap karját.

A víz folyik.
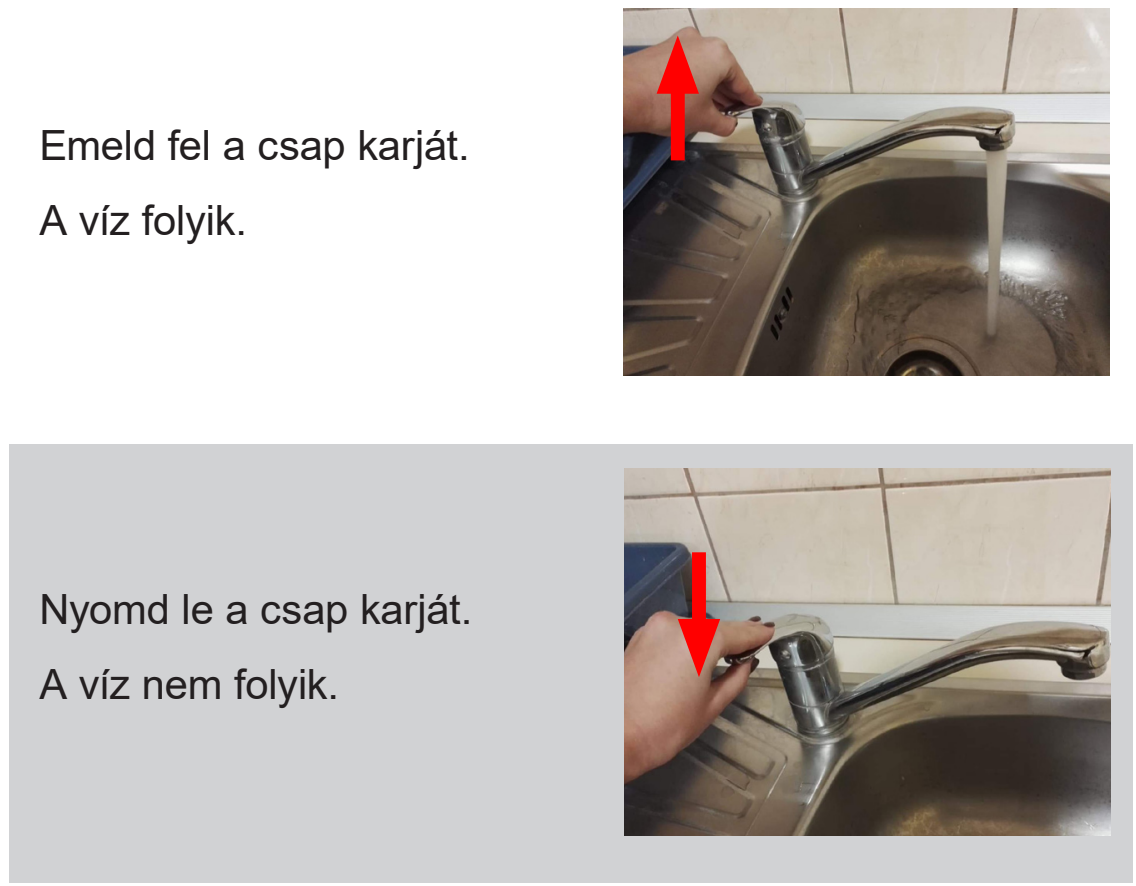


\title{
Könnyen érthető \\ kommunikáció értelmi sérült személyekkel
}

\author{
Névmások használatának vizsgálata \\ könnyen érthető információkat tartalmazó \\ dokumentumokban
}

\begin{abstract}
A könnyen érthető kommunikáció lehetővé teszi az alapvető emberi jogok biztosítását, akadálymentes és befogadó környezet megteremtését, az önálló döntéshozatalt és az önrendelkezést, valamint alkalmas az önérvényesítés támogatására. Lehetővé teszi az aktív, tudatos és valódi részvételt a társadalomban mindazok számára, akiknek a sztenderd kommunikáció megértése általánosságban vagy bizonyos helyzetekben kihívást okoz. A tanulmány célja, hogy fogyatékosságtudományi, emberi jogi paradigma felöl közelítve, a grammatika eszközeit segítségül hívva bemutassa, hogy a könnyen érthető kiadványokban hogyan alkalmazzák a szerzők a névmásokat, valamint azt, hogy a magyar nyelvű szabályrendszerek szabályai ezzel kapcsolatban milyen útmutatást nyújtanak. Fö kérdéseink, hogy a magyar nyelvủ szabályrendszerekben milyen utasításokat találunk a névmások használatára vonatkozóan, illetve a könnyen érthető kiadványokban hogyan jelennek meg a névmások. A kutatás elméleti kutatómunka, összehasonlító elemzés. A kutatás eredményei lehetővé teszik, hogy a magyar nyelvű szabályrendszerekben pontosítani tudjuk a névmások használatára vonatkozó szabályokat, hiszen a jelenlegiek szubjektíven értelmezhetök, és nem elég részletesek. Ugyanakkor hangsúlyozzuk, hogy a könnyen érthetö üzenet készítésekor mindig az aktuális célcsoport szükségleteit és képességeit fontos figyelembe venni.

Kulcsszavak: könnyen érthető kommunikáció, szabályrendszer, névmások, értelmi akadályozottság
\end{abstract}

\section{BEVEZETÉs}

Az információkhoz való hozzáférés a kulcs a világ dolgaiban való tájékozódáshoz, a mindennapi döntések meghozatalához, ezáltal pedig az életünk felett való rendelkezéshez (Horváth, 2020). A mai tudásalapú társadalomban az információ még inkább felértékelödik, nemcsak a társadalmi részvétel feltétele, hanem a versenyképesség feltétele is, hiszen határ nélkülivé, globálissá és dominánssá vált az információ- és tudásszektor (Avornicului \& mtsai, 2016; Kerner, 2020). Almási (2016) azt írja, az információ az egyik olyan láthatatlan hatalom, mely a világot irányítja. Véleménye szerint 'az információáramlás hierarchizált folyamat. Más szóval: hatalmi megoszlás. Akik hozzáférnek az információhoz (vagyis „tudnak”), azok lekörözik - rosszabb esetben kizsákmányolják - azokat, akik nem férnek hozzá az információhoz (azaz: nem tudnak)' (Almási, 2016:o.n.) Az információs, illetve tudásalapú társadalom fogalma, valamint az információ értékének növekedése mára olyannyira elfogadott tény, hogy a közbeszédet is tematizálja. Még hétköznapi, nem tudományos igényű médiumban is olvashatunk arról, hogy „az új vagyon (...) az információ és a társadalmi tőke. Amiben az a rémisztő, hogy ezek még inkább behozhatatlan előnyt garantálnak, mint a pénz" (Kerner, 2020:0.n.). 
„Az információs társadalom nyújtotta lehetőségek erősítik az esélyegyenlőséget a fogyatékos személyek számára. A fogyatékos személyt az információs esélyegyenlőség megilleti az információs társadalmi szolgáltatások igénybevételekor" [Fot. 7. § (2) bek.]. Az értelmi sérült emberek kirekesztésének egyik oka az, hogy a környezet nem akadálymentes számukra. Esetükben az információk hozzáférhetővé tétele a könnyen érthető kommunikáció által az akadálymentesítés eszköze (Gruiz, 2009).

„A könnyen érthető kommunikáció az információ egyszerü, letisztult áramoltatása a kommunikációs zajok minimalizálásával" (Farkasné Gönczi, 2018a:65.). A könynyen érthető kommunikáció segítséget jelent az alapvető emberi jogok biztosítására, akadálymentes és befogadó környezet teremtésére, az önálló döntéshozatal és az önrendelkezés támogatására, az aktív, tudatos és valódi részvételre a társadalomban mindazok számára, akiknek a sztenderd kommunikáció megértése általánosságban vagy bizonyos helyzetekben kihívást okoz. Az információ felértékelődése által egy befogadó társadalomban egyre inkább nélkülözhetetlenné válik az információ hozzáférhetővé tétele, hiszen enélkül a szakadékok csak mélyülnek.

Gyógypedagógusként feladatunk a sérült emberek életviteli nehézségeinek kezeléséhez, a környezetük rendezéséhez és a társadalmi integrációjához segítséget nyújtani (ELTE BGGYK, 2019). A gyógypedagógusok etikai kódexe alapján feladatunk az önrendelkezési jog tiszteletben tartása, a teljes körű tájékoztatás és a döntéshozás támogatása a döntés hátterének és következményeinek megvilágításával (Magyar Gyógypedagógusok Egyesülete, 2011). Ennek egyik facilitáló eszköze lehet a könnyen érthetö kommunikáció.

A könnyen érthető információt a befogadó személy nyelvi szintjén kell kódolni. Az értelmi sérült személyeknek az elvont fogalmak, a viszonyszók, és így a névmások értelmezése - mint például a névmás szófajú szavak - nehézséget okoznak (Horváth, 2019). Fontos tehát meggyőződnünk arról, hogy az általunk használt, az üzenet kódolását meghatározó szabályrendszerek útmutatásai megfelelőek-e ahhoz, hogy az információt a célcsoporthoz a leginkább hozzáférhető módon juttassuk el.

Tanulmányomban ezért azt vizsgálom, hogy a könnyen érthető kiadványokban hogyan alkalmazzák a szerzők a névmásokat, valamint azt, hogy a magyar nyelvű szabályrendszerek szabályai ezzel kapcsolatban milyen útmutatást nyújtanak. A tanulmány a Magyarországon magyar nyelven elérhető, illetve a magyar nyelvű könnyen érthető szövegekre vonatkozó szabályrendszereket vizsgálja fogyatékosságtudományi, emberi jogi paradigma felöl közelítve, a grammatika eszközeit is segítségül hívva. A vizsgált szabályrendszereket 2002-2009 között adták ki, illetve egy esetben a kiadás dátuma nem ismert. Jelen tanulmány keretei nem alkalmasak arra, hogy revizionálják a jelenleg alkalmazott szabályrendszereket, hiszen előzetes kutatások a témában még nem születtek. Ezért feladatomnak azt tekintem, hogy feltárást végezzek a témában; így átfogó képet kaphatunk a jelenlegi gyakorlatról, ami aztán további elméleti és gyakorlati kutatások alapja lehet. A következőkben bemutatom a könnyen érthető kommunikáció fogalmát, célját, funkcióit és célcsoportjait, majd a könnyen érthető kommunikáció szabályrendszereit, különös tekintettel a névmások használatára vonatkozó szabályokra. Bemutatom azokat az ismereteket, amelyek arra vonatkoznak, hogy az értelmi sérült emberek hogyan tudják értelmezni a névmásokat. A tanulmány második felében a kutatási kérdések, módszer- és mintaválasztás felvázolása után ismertetem, hogy a vizsgált kiadványokban mit tapasztaltam a névmások használatára vonatkozó szabályok betartása terén. 


\section{ELMÉLETI HÁTTÉR}

\section{A könnyen érthetö kommunikáció}

„Az értelmi fogyatékossággal élő emberek olyanok, mint bárki más. Sokat tehetnek az életben, ha megkapják a megfelelő támogatást. Az értelmi fogyatékossággal élők számára nehezebb lehet a dolgok megértése és az új dolgok tanulása. Ezért nagyon fontos, hogy az értelmi fogyatékossággal élök számára a kapott információk egyszerüek és könnyen érthetőek legyenek. A megfelelő információ segít az embereknek, hogy felismerjék saját szükségleteiket. Ez a felismerés segíti őket saját választásaik és döntéseik meghozatalában. Ha az értelmi fogyatékossággal élő emberek nem jutnak megfelelö információkhoz, akkor kirekesztődnek. Nem lesznek képesek bekapcsolódni a körülöttük történő dolgokba, eseményekbe. Arra kell várniuk, hogy döntsenek helyettük" (Inclusion Europe \& ÉFOÉSZ, 2009b:6-7.).

Egy angol nyelvű szakirodalmakat vizsgáló metaanalízisből kiderül, hogy a könynyen érthető információ fogalmának meghatározására nincs általánosan elfogadott fogalmi koncepció, ezért a fogalomhasználat sem egységes (Chinn \& Homeyard, 2007).

A könnyen érthető kommunikáció egy szemléletmód, mely biztosítja az információhoz való hozzáférést, és ezáltal a társadalmi részvétel egy akadályát szünteti meg. Egyben egy módszertan is, segítség az értelmi sérült személyek számára, ami a nehezen érthető, bonyolult információk átalakítását szolgálja (Horváth, 2017). Olyan módszer, ami az értelmi sérült személyek számára a nem érthető, hétköznapi információkat rejtő sztenderd nyelvhez való hozzáférést támogatja, ezáltal az információs és kommunikációs akadálymentesítés eszköze (Horváth, 2020). Mindemellett az emberi jogok érvényesülését biztosító eszköz is. A fejezet bevezetéseként idézett szöveg számomra úgy értelmezhető, hogy a könnyen érthető kommunikáció az önrendelkezés és a befogadás egy eszköze, mely a kirekesztődés mellett a kiszolgáltatottságot is csökkenti. Ezt az értelmezést nagyon találóan szemlélteti Horváth Péter László a doktori értekezésében (2020:28) azzal a megállapítással, hogy „ami a kerekesszéket használó személynek a rámpa, a siket személynek a jelnyelv, az az értelmi sérült személynek a könnyen érthető információ".

A hazánkban 2007-ben ratifikált a Fogyatékossággal élő személyek jogairól szóló ENSZ egyezmény rögzíti a fogyatékos személyek által hozzáférhető információk biztosítását. A 9. cikk a fogyatékos emberek önálló életvitelének és az élet valamennyi területén történő teljes körü részvételének lehetővé tételét nyomatékosítja. A részes államok kötelezettséget vállalnak arra, hogy a fizikai környezethez, a közlekedéshez, az információhoz és kommunikációhoz - ezáltal az információs és kommunikációs technológiákhoz és rendszerekhez -, valamint más, nyilvánosan hozzáférhető vagy rendelkezésre álló lehetőségekhez és szolgáltatásokhoz való hozzáférést biztosítsák. Az egyezmény a hozzáférési akadályok és korlátok felszámolásának egyik eszközeként a könnyen érthető és olvasható jelzéseket jelöli meg. A 21. cikk kiemeli, hogy véleményének kifejezésére minden embernek joga van. Véleményt mondani és döntést hozni csak megfelelő információk biztosításával lehet, ennek pedig egyik eszköze a könnyen érthető kommunikáció (fogyatékosságügyi ENSZ egyezmény, 2006). 
Gruiz (2009) a könnyen érthető kommunikációt kommunikációs eszközként írja le, mely alapvetően szükséges ahhoz, hogy az értelmi sérült személyek képessé váljanak emberi jogaik és alapvető szabadságuk teljes gyakorlására.

A könnyen érthető kommunikáció egyik célja tehát a kommunikációs akadálymentesítés a könnyebben olvasható szöveg és az információk megértését lehetővé tevő eljárás biztosításával. Alapvetően nem az olvasás megkönnyítésével, hanem az értő olvasás támogatásával történik az információ megértésének elömozdítása. A könnyen érthető közlésmód a köznyelv egy változata, amely vagy az abban megjelenő információ fontos tartalmi egységeit jeleníti meg, vagy önálló információs tartalommal rendelkezik egyszerü, letisztult formában (Farkasné Gönczi, 2018a). A kommunikációs paradoxon - miszerint a nem kommunikálás is kommunikációs funkcióval bír (Watzlawick \& mtsai, 2003) - alapján úgy gondolom, hogy a könnyen érthető kommunikáció a többségi társadalom megnyilvánulása az értelmi sérült emberek felé. Azt jelzi, hogy számít a véleményük, hogy olyan embernek tartjuk őket, akik képesek döntést hozni, véleményt alkotni, cselekedni és a társadalom kompetens tagjai.

A könnyen érthető kommunikáció részvételi, tanulási és hídfunkcióval bír. A társadalmi részvételhez olyan formában kell az információt biztosítani, hogy azt azok a személyek is értsék, akiknek nyelvi kompetenciája, illetve előzetes tudása nem teszi lehetővé az általános csatornákon közzétett szövegek értelmezését. A könnyen érthető kommunikáció tanulási funkciója az általános és szakszövegek elérhetővé tételében, illetve az érthető szöveg által biztosított, motiváló hatású sikerélményben nyilvánul meg. A hídfunkció kevésbé a könnyen érthető kommunikációra, inkább az egyszerüen érthető kommunikációra vonatkozik. Ez azt jelenti, hogy bizonyos csoportok számára (például idegen nyelvet tanulók) a sztenderd, nehezen értelmezhető szöveg megértéséhez vezethetnek a könnyen érthető szövegek. Tehát ezek segítségével az eredeti, bonyolult szöveg, az alapváltozat is könnyebben megérthetővé válhat. A hídfunkció akkor teljesül, ha az alapszöveg és annak könnyebben érthető változata egyszerre elérhető (Horváth, 2020).

A könnyen érthető kommunikáció fogalmának körülhatárolását nehezíti a hasonló, de nem azonos jelentésű kifejezések szinonimaként való alkalmazása. Ez a magyar, angol, illetve német nyelvterületen is létező jelenség. A magyar nyelvben sokféle fogalmat alkalmazunk a e terület megjelölésére: például „könnyített nyelv”, „könnyen érthető és olvasható információ” vagy „egyenlő eséllyel hozzáférhető információ”, másfelől „egyszerüen érthető kommunikáció” vagy más szóval „közérthető kommunikáció". Ezek a kifejezések azonban eltérő célcsoportot takarnak, illetve tükrözik a célcsoporthoz való hozzáállást, a fogyatékosság értelmezését is. A hozzáférhető, illetve egyenlő eséllyel hozzáférhető információ kifejezés utal arra, hogy az információhoz való hozzáférés a társadalomban való részvétel kulcsa, alapvető emberi jog. Minden embernek hozzáférhető információra van szüksége. Ez a kifejezés a fogyatékosság emberi jogi értelmezéséhez áll közel. A könnyített nyelv használata magában hordoz egy minősítést a befogadó nyelvi képességeire vonatkozóan, miszerint ő nem képes megérteni a sztenderd nyelvet, mert nyelvi és kognitív hiányosságai vannak. Használata stigmatizációhoz, elöítéletekhez, illetve az előítéletek megerősítéséhez vezethet. Ez a kifejezés a fogyatékosság medikális értelmezéséhez kapcsolódik (Horváth, 2020). 
A könnyen érthető kommunikáció nem mindenki számára jelent hozzáférhető információt. Jól körülhatárolható azon emberek csoportja, akiknek ehhez ez a megfelelö eszköz (Farkasné Gönczi, 2018a).

Nomura és munkatársai (2010) két nagy célcsoportot határoznak meg. Az egyik azok a fogyatékos személyek, akiknek tartósan könnyen érthető szövegekre van szükségük. A másik az átmenetileg korlátozott nyelvi vagy olvasási képességgel élő emberek, akiknek életük egy adott szakaszában van szükségük ezekre az anyagokra. Ezen csoportok életkor alapján tovább bonthatók: gyerekekre, fiatal felnőttekre és felnőttekre.

A könnyen érthető kommunikáció hazai gyakorlatának elsődleges célcsoportja az értelmi sérült emberek. A könnyen érthető kommunikáció másodlagos célcsoportja a megértési problémákkal rendelkező emberek. A harmadlagos célcsoportba pedig bárki beletartozhat (Farkasné Gönczi, 2018a).

Baker és munkatársai (2010) kutatásukban azt találták, hogy az értelmi sérült személyek 90 százalékának van kommunikációs problémája, amely az esetek felében jelentős kommunikációs deficitet jelent.

A nemzetközi szakirodalom a célcsoportot jobban kibontja. Elsődleges célcsoportnak az értelmi sérült, a specifikus tanulási zavart - diszlexiát - mutató és a gyenge nyelvi készséggel rendelkező személyeket nevezi meg. Másodlagos célcsoportként jelöli az adott ország nyelvét idegen nyelvként gyengén beszélő, a szociálisan hátrányos helyzetủ és a demenciában érintett személyeket, illetve más sérülésspecifikus csoportokat (Farkasné Gönczi, 2018a).

Csató (2002) szerint könnyen olvasható olvasmányra olyan embereknek van szüksége, akiknek gondot okoz az adott ország nyelvén való írás, olvasás.

Horváth (2020) támogatási szükséglet alapján határozza meg a könnyen érthető kommunikáció célcsoportjait. Elsődleges célcsoport az intellektuális funkciók területét tekintve magas támogatási szükségletű személyek. Szintén az elsődleges célcsoportba tartoznak azok a siket személyek, akiknek elsődleges nyelve a jelnyelv, a nemzeti nyelvet második nyelvként használják. Emellett az alacsony nyelvi kompetenciával rendelkező vagy eltérő anyanyelvű személyek, illetve gyerekek vagy idős emberek lehetnek a másodlagos célcsoport tagjai.

A könnyen érthető kommunikáció tehát egy szemléletmód, egy módszertan és egy eszköz is. Szemléletmód, amely akadályt szüntet meg az információhoz való hozzáféréssel, módszertan, amely a bonyolult információt érthetővé alakítja, és eszköz az önrendelkezéshez és befogadáshoz. Összességében elmondható, hogy a könnyen érthető kommunikáció fogalmának pontos körülhatárolása fontos, hogy el tudjuk választani a többi hasonló, szinonimaként használt, de nem azonos jelentéssel bíró kifejezéstől. Ez hozzájárul ahhoz, hogy egy érintett személy a számára leginkább dekódolható információhoz jusson hozzá. A könnyen érthető kommunikáció nem teszi mindenki számára elérhetövé az információt, az egy adott körülhatárolható célcsoporthoz szól.

\section{A könnyen érthetö kommunikáció szabályrendszerei}

A továbbiakban általánosságban mutatom be a jelenleg magyar nyelven elérhető szabályrendszereket. A könnyen érthető kommunikáció szabályrendszerei az üzenet közlőjét támogatják abban, hogy az üzenetet úgy tudja kódolni, hogy a befogadó 
kompetenciájától függően a leginkább megfelelően tudja az üzenetet dekódolni. A szabályrendszer a könnyen érthető kommunikáció alappillére, mert megmondja, hogy az üzenetet hogyan lehet könnyen érthetően megfogalmazni. Magyarországon és a nemzetközi színtéren is nagyon sok szabályrendszerrel találkozunk. Ez egyrészt rugalmasságra ad lehetőséget, másrészt viszont bizonytalanságot okoz, és a módszer egységes használatát nehezíti meg (Horváth, 2020).

A magyar nyelv értelmező szótára szerint (2016) a szabály az írásban rögzített vagy szokáson alapuló rendezési elv, ami magatartást, viselkedést, eljárásmódot határoz meg, amelyhez igazodni, alkalmazkodni kell. A könnyen érthető kommunikáció szabályrendszere tehát a fenti meghatározás alapján egy olyan rendezési elv, irányító erejü megállapítás, melyhez igazodni kell, és meghatározza a könnyen érthető kommunikációval készült szövegek törvényszerűségeit. Úgy gondolom, hogy a szabályrendszerek közötti eltérések pont azt nehezítik meg, amire a meghatározás szerint egy szabályrendszer hivatott - a rendszerező elvhez való igazodást a törvényszerüségek alapján.

Magyar nyelven jelenleg a következő öt szabályrendszer érhető el:

A Csató (2002) által szerkesztett „Egyszerűen, érthetően - Útmutató könnyen érthető tájékoztatók készítéséhez" című kiadvány az International League of Societies for Persons with Mental Handicap (továbbiakban ILSMH) szervezet által kiadott útmutató fordítása.

A Down Alapítvány gondozásában megjelent „Hogyan készítsünk könnyen érthető segédanyagot - Irányelvek" című kiadvány a Mentális Akadálymentesítés projekt keretében került kidolgozásra (Horváth, 2020; Gruiz, é.n.).

Az Inclusion Europe a korábbiakban már említett ILSMH jogutód szervezete (Horváth, 2020). A szervezet az értelmi sérült emberek jogaiért - az emberi jogokért, a társadalmi integrációért és a diszkrimináció ellen - küzd (Inclusion Europe \& ÉFOÉSZ, 2009a). Elkészítettek egy egységes szabályozási útmutatót, „Információ mindenkinek - A könnyen érthető kommunikáció európai alapelvei" címmel (Farkasné Gönczi \& Graf-Jaksa, 2009). Emellett két további kiadvány is készült, az egyik a" Ne írjon nekünk, nélkülünk! - Hogyan vonjunk be értelmi fogyatékossággal élő embereket a könnyen érthető szövegek készítésébe?" című, az értelmi sérült személyek képzéséhez nyújt segítséget, „Az egész életen át tartó tanulás oktatóinak képzése - Iránymutatás azoknak az embereknek a képzéséhez, akik könnyen érthető dokumentumokat készítenek" című kiadvány pedig a képzők képzéséhez ad támpontokat (Inclusion Europe \& ÉFOÉSZ, 2009a; Inclusion Europe \& ÉFOÉSZ, 2009b; Inclusion Europe \& ÉFOÉSZ, 2009c).

A kiadványok közötti különbségeket a publikáció célja, célcsoportja, az általuk a könnyen érthető kommunikáció célcsoportjaként meghatározott emberek csoportja, illetve az üzenet típusának szempontjából az 1. táblázatban mutatom be. 

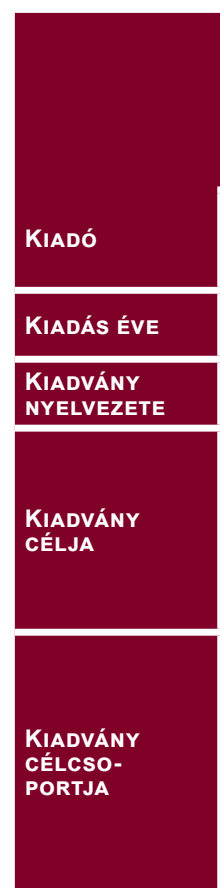

\section{A KÖNNYEN} ÉRTHETŐ

KOMMUNIKÁCIÓ CÉLCSOPORTJA

\section{A KÖNNYEN ÉRTHETÓ ÜZENET TÍPUSA}

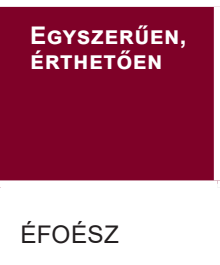

2002

sztenderd

gazdasági és társadalmi részvétel biztosítása, valamint egységes európai útmutató létrehozása

mindenki, aki szeretné, hogy az olvasási és megértési nehézségekkel élö emberek is részt vehessenek a mindennapi életben

\section{olvasási/írási/} tanulási nehézségekkel élő személyek

írott szöveg, hangkazetta, videokazetta, interaktív média

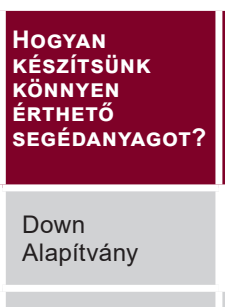

é.n.

sztenderd

sarengerd

mentális akadálymentesítés elősegítése

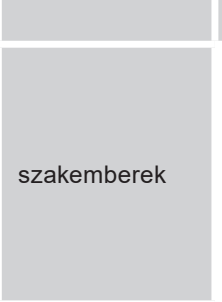

nehezen értő felnőttek

írott szöveg nyomtatva, CD-n, DVD-n vagy online

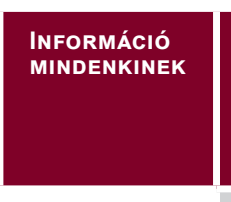

Inclusion

Europe -

ÉFOÉSZ

\section{9}

könnyen

érthető

egységes eu-
rópai útmutató,
emberi jogok
biztosítása

mindenki, aki könnyen érthető formában szeretne információkat létrehozni

értelmi sérült/ nem magyar anyanyelvü/ nehezen olvasó személyek

nyomtatott és elektronikus írott szöveg, hangfelvétel, film

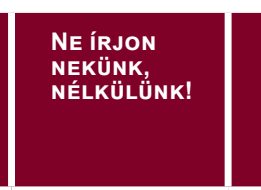

Inclusion
Europe -
ÉFOÉSZ

2009

könnyen érthető

értelmi sérült személyek részvétele a könnyen érthető tartalmak készítésében

mindenki, aki könnyen érthető formában szeretne információkat létrehozni

a felnőttképzésben oktató képzők

$\begin{aligned} & \text { értelmi sérült } \\ & \text { emberek }\end{aligned}$
írott szöveg

értelmi sérült emberek és a többi diák

írott szöveg, előadás

\section{1. táblázat. A könnyen érthető kommunikáció magyar nyelven elérhető szabályrendszerei}

\section{A névmásokra vonatkozó szabályok}

Az alábbiakban áttekintem, hogy a különböző magyar nyelvű szabályrendszerek milyen szabályokat tartalmaznak a névmások használatára vonatkozóan.

A névmások olyan szavak, melyek közvetetten utalnak a valóságra, más alapszófajú szavak helyettesítői. Konkrét jelentéstartalmukat tehát csak a szövegkörnyezet, illetve beszédhelyzet alapján nyerik el. A névmások egy zárt szóosztály, ami azt jelenti, hogy új névmások nem keletkeznek. Csoportosíthatók a jelentés és a helyettesített szófaj szerint is. Jelentés szerint megkülönböztetünk személyes, visszaható, kölcsönös, mutató, kérdő, vonatkozó, határozatlan és általános névmásokat. Helyettesített szófajok szerint csoportosítva pedig főnévi, melléknévi és határozószói névmásokat (Keszler \& Lengyel, 2020).

$A z$ „Egyszerüen, érthetően - Útmutató a könnyen érthető kommunikáció készítéséhez" című kiadványban konkrétan a névmásokra vonatkozó szabályt, ajánlást nem találtam. Mégis kiemelnék két szabályt, amelyek támpontot adhatnak ebben a kérdésben: 
1. „Kerüljük az elvont fogalmakat. Ha mégis előkerülhetnek, konkrét példákkal segítsük a megértést."

2. „Használjuk következetesen a szavakat. Egy-egy dologra mindig ugyanazt a szót használjuk - még akkor is, ha a szóismétlés egyhangúvá teszi a szöveget" (Csató, 2002:14).

A névmás olyan szófaj, mely csak a használat alkalmával a beszédben vagy a szövegben kap határozott tárgyi jelentést. Az elvont fogalmakra vonatkozó szabályt tehát alkalmazni kell a névmások esetében.

Úgy gondolom, hogy a névmások használata azért is kézenfekvő lehet, mert megszoktuk, hogy írott szöveg készítésekor választékosan fogalmazunk és kerüljük a szóismétléseket. A második idézett szabály alapján viszont a könnyen érthető szövegek készítésekor a szóismétlés éppen nem kerülendő, hanem segítheti a szöveg megértését.

A „Hogyan készítsünk könnyen érthető segédanyagot? - Irányelvek” címü kiadványban a következő szabályt találtam a névmásokra vonatkozóan: „Névmások használatakor körültekintően kell eljárni. Mindig gondoskodjunk arról, hogy a szövegből világosan kiderüljön, kire vagy mire vonatkozik a névmás. Amennyiben ez nem egyértelmü, használjuk inkább a teljes szót, vagy kezdjünk új mondatot" (Gruiz, é.n:4).

A szabály tehát engedi a névmás használatát azzal a kikötéssel, ha a szövegböl világosan kiderül, hogy mire vonatkozik. Úgy gondolom, hogy az a megfogalmazás, hogy „világosan kiderül”, nem tartalmaz pontos információkat. Ebből nem tudjuk meg, hogy szükséges-e, hogy a szövegben leírva szerepeljen-e a névmás tárgya, illetve ha szerepelnie kell, akkor a névmás előtt vagy után, illetve mekkora távolságra a névmástól.

Az ÉFOÉSZ által fordított, az Inclusion Europe által kiadott szabályrendszerek közül az „Információ mindenkinek - A könnyen érthető kommunikáció európai alapelvei” című kiadványban találtam a névmások használatára vonatkozó szabályt. „A névmások használata fokozott figyelmet igényel. A névmások olyan szavak, amelyeket a személyek vagy dolgok helyett használunk, miközben beszélünk róluk. Például a következő szavak névmások: én, neki, azt. Mindig ellenőrizzük, hogy a megfelelő névmást használjuk. Ha nem egyértelmű, hogy kire vagy mire gondolunk, akkor inkább kerüljük a névmások használatát" (Inclusion Europe \& ÉFOÉSZ, 2009:15).

Ez a szabályrendszer tehát támogatja a névmások használatát abban az esetben, ha a megfelelő névmást használják a szövegben, illetve, ha egyértelmü, hogy mi a névmás tárgya. Véleményem szerint az, hogy „egyértelmü, mi a névmás tárgya”, nem ad elég pontos információt. Sejtjük, hogy nem mindenki számára ugyanaz az egyértelmü. Nem találunk utasítást arra vonatkozóan sem, hogy a névmást a fogalom pontos megjelöléséhez képest hol helyezzük el.

Emellett még egy névmásokra vonatkozó szabályt találtam a kiadványban: „Mindig közvetlenül az adott személyekhez beszéljünk. Használjuk a te vagy ti szavakat" (Inclusion Europe \& ÉFOÉSZ, 2009:11).

Ez a szabály tehát a személyes névmás, az egyes szám második személy, illetve a többes szám második személy használatára szólít fel.

A magyar nyelven elérhető öt szabályrendszer közül tehát 2 - Gruiz (é.n.) és az Inclusion Europe \& ÉFOÉSZ (2009) kiadványa -, amely kifejezetten a névmás használatára vonatkozó szabályt fogalmaz meg. Lehetséges, hogy ezek a szabá- 
lyok nem elég cizelláltak, nem tartalmaznak elég pontos információkat ahhoz, hogy a névmásokat egységesen jól lehessen alkalmazni a könnyen érthető szövegekben.

\section{A névmások értelmezése értelmi sérült személyek számára}

Az értelmi sérülés befolyásolja az egyén nyelvi funkcióit (Subosits, 1994). Nehéz viszont a nyelvi funkciókra vonatkozóan általános megállapításokat tenni, hiszen a kutatások eredményei azt mutatják, hogy a teljesítmények megítélésében kerülni kell ezeket az általánosításokat. A nyelvi, illetve a beszédfejlődést befolyásoló faktorok - például a neuroanatómiai eltérések, a specifikus orofaciális profilok, a hipotónia, a halláskárosodás vagy a verbális rövidtávú emlékezet - eltérö mértékben és kombinációkban károsodhatnak. Sajátos mintázatuk egyéni képességprofilt eredményez. Ezáltal a beszédbeli, nyelvi és kommunikációs képességekben is jelentős egyéni eltérések lehetnek (Tar, 2013).

A könnyen érthető információk készítése során szem előtt kell tartani, hogy a közlő a befogadó személy nyelvi szintjéhez igazodva készítse el az üzenetet. Ehhez szükséges a célszemély vagy a célcsoport nyelvi kompetenciájának jellemzőit ismerni. Ez viszonylag könnyen kivitelezhetö abban az esetben, ha a sztenderd szöveg fordítása egy konkrét személy számára készül. A tudományos kutatások alapján viszont nagy vonalakban egy célcsoport, például az értelmi sérült személyek szövegértelmezéséről, információszerzési ismereteiről is lehetnek ismereteink (Horváth, 2019).

A bonyolult nyelvi szinteket használó szövegek nehezen érthetők. A sokszorosan összetett, hosszú mondatok, a sok fönév és a hosszú és ismeretlen szavak gyakori használata megnehezíti a szöveg értelmezését. A hosszú, bonyolult és összetett mondatok egyszerübb mondatokra bontásakor megnő a referenciális kifejezések - névmások, főnevek, tulajdonnevek - használatának száma (Hegedűs, 2020). Az értelmi sérült személyeknek nehézséget okoz a névmások értelmezése. Megértésükhöz szükséges ez a képesség, tehát ez egy olyan szófaj, amelynek megértése nem könnyü. Jelentésüknek megfejtéséhez tudni kell, hogy melyik szó helyettesítésére alkalmazták. Ezért a névmások használatát javasolt kerülni (Horváth, 2019). Kifejezetten a névmások megértése több diagnózis esetén is nehezített lehet. Friedman és munkatársai (2019) kutatásukban azt találták, hogy a mutató névmások és a személyes névmások megértése fragilis X szindróma és autizmus spektrum zavar esetén is kihívást jelent. Sanoudaki és Varlokosta (2014) Down-szindrómás személyek nyelvi kompetenciáit vizsgálva azt találták, hogy a visszaható névmások értelmezése nehézséget jelent az érintett személyek számára.

Összegzésként tehát elmondható, hogy a könnyen érthető információk készítéséhez nemcsak módszertani ismeretekre van szükség, hanem fontos a célcsoport meghatározása és nyelvi funkcióinak megismerése. Ezáltal válik lehetségessé az, hogy az információk a lehető legpontosabban és érthetően jussanak el az érintett személyekhez. Amennyiben ezen szövegek célcsoportja olyan értelmi sérült személyek, akiknek a nyelvi funkcióiról nincs bővebb ismeretünk, akkor a szakirodalom alapján nem célszerű a névmások alkalmazása. 


\section{A KUTATÁs BEMUTATÁSA}

Tanulmányomban arra keresem a választ, hogy a magyar nyelvű könnyen érthető kiadványokban használnak-e névmásokat, és ha igen, akkor ezek használata milyen mintázatokat, törvényszerüségeket mutat. Emellett arra is kíváncsi vagyok, hogy ezek a mintázatok és törvényszerüségek megegyeznek-e a magyar nyelvű szabályrendszerek útmutatásaival.

A kutatási kérdések az alábbiak:

1. A magyar nyelvű könnyen érthető dokumentumokban használnak névmásokat?

2. Amennyiben a magyar nyelvű könnyen érthető dokumentumokban használnak névmásokat, az a szabályrendszerekben rögzített útmutatásoknak megfelelöen történik?

3. Amennyiben magyar nyelvű dokumentumokban használnak névmásokat, milyen jellegzetességeket lehet megfigyelni? Az ugyanattól a kiadótól megjelent kiadványokban a névmások használata ugyanolyan szabályszerúségek szerint történik?

A kutatásom „top-desk research”, elméleti kutatómunka, ezen belül pedig öszszehasonlító elemzés. A témában még nem történt előzetes feltárás. Képet ad arról, hogy a hazai könnyen érthető kiadványokban a szerzők hogyan használják a névmásokat, ezek mennyiben egyeznek meg a szabályrendszerekben található útmutatásokkal. Ezáltal lehetőség nyílik annak átgondolására, hogy a jelenleg alkalmazott szabályrendszerekben megfelelő minőségű és mennyiségű információ áll-e rendelkezésre a névmások használatával kapcsolatban. Emellett arról is lesznek ismereteink, hogy egy kiválasztott szabály a különböző szabályrendszerekben megtalálható-e, illetve milyen formában található meg. Valamint megfigyelhetjük, hogy a szabályrendszerekben található útmutatást hogyan és mennyiben alkalmazzák a különbözö kiadványokban.

A minta kiválasztását követően a kiadványokban kijelöltem az összes névmás szófajú szót. „A névmások főneveket, mellékneveket, számneveket helyettesítő szók. Akkor válnak határozottá, ha a beszédben valakire vagy valamire rámutatunk vagy utalunk velük" (Rácz \& Takács, 1974:124). A kiadványok elemzésekor minden karaktert számításba vettem, tehát a külső és belső borítókon szereplő szöveggel is dolgoztam. Ezután meghatároztam a kijelölt névmások fajtáit, majd táblázatba rendeztem a különböző kiadványokban található névmásokat fajta szerint, végül ezeket összesítettem. Így született meg a kész adatbázisom az elemzések elvégzéséhez és a megfigyeléshez.

Tanulmányomban a nem valószínűségi mintavételi eljárások közül a szakértői és a véletlenszerű mintavételi eljárást választottam. Attól a három kiadótól választottam véletlenszerüen 2-2 publikációt, amelyek a legtöbb könnyen érthető dokumentumot adták ki nyomtatott verzióban. Ezek ábécé sorrendben a Down Alapítvány, az ÉFOÉSZ, és az FSZK. Az alábbi hat publikációt tanulmányoztam:

Báthory N., Czakó T. \& Sallai Ilona (é.n.). Választójogot Mindenkinek! - Európai Parlamenti választások 2019. ÉFOÉSZ, Budapest.

Lévai E. \& Nagy E. (2016). Mi Nők - Szexualitás. ÉFOÉSZ, Budapest. 
Down Alapítvány (2014a). A betegek jogai - Információ egészségügyi szolgáltatások igénybevételéhez. Down Alapítvány, Budapest.

Down Alapítvány (2014b). Banki ügyintézés - Banki szolgáltatások igénybevétele, bankkártya használat. Down Alapítvány, Budapest.

Farkasné Gönczi R. (2018e). Dolgozni jó! - Ismerkedés a munka világával. FSZK, Budapest.

Dénesné Spitzer É., Farkasné Gönczi R., Kiss E., dr. Kissné Huszár A. \& Nagy L. (2019). Mi az a kiváltás? - Ismerkedés a közösségi befogadással. FSZK, Budapest.

\section{KUTATÁSI EREDMÉNYEK BEMUTATÁSA, ÉRTELMEZÉSE ÉS ELEMZÉSE}

A 2. táblázat az 1. mellékletben bemutatja, hogy a kiadványban a különböző névmások milyen megoszlásban találhatók, illetve azt, hogy melyek ezek a névmások az egyes kiadványokban. A kutatás elkészítésekor érvényben lévő nyelvtani szabályok alapján a birtokos névmásokat is vizsgáltam. Azóta a Kis magyar grammatika című könyvben megjelent a névmások új felosztása. Eszerint az eddig birtokos névmásként tárgyalt elemeket már a személyes névmások között tartjuk számon, mivel ezek személyes névmásból és birtokjelből képződnek. Viszont a birtokjel sem a fönevek, sem a főnévi névmások körében nem okoz szófajváltást, ebből következően személyes névmások maradnak az így képzett szavak (Keszler \& Lengyel, 2019). Az ÉFOÉSZ kiadványaiban (Báthory, Czakó \& Sallai, é.n.; Lévai \& Nagy, 2016) az elsőben 1028 szóból 101-nek névmás a szófaja, a második kiadványban 1565 szóból 103 volt névmás. Az első tárgyalt kiadványban 26 esetben volt névmás a mondat első szava, tehát a névmások több mint negyede mondatkezdő szóként szerepelt; a második kiadványban 42 alkalommal, tehát majdnem az esetek felében. Feltételezhető, hogy a névmások értelmezése akkor a legegyszerübb, ha az, amit jelöl, ugyanabban a mondatban, a névmás előtt jelenik meg.

Ezekben a kiadványokban a névmások közül a mutató névmások fordultak elő a legnagyobb arányban, elöbbiben 43 százalékban, míg az utóbbiban 52 százalékban. Az elöbbiben hasonló arányban szerepeltek kérdő (18 százalék), vonatkozó (16 százalék) és személyes (14 százalék) névmások. A második kiadványban a második legtöbbször szereplő névmás a vonatkozó névmás (22 százalék), majd a személyes névmás (12 százalék), végül a kérdő névmás ( 7 százalék). A kiadványokban csak néhány általános névmás fordult elő ( 6 százalék és 3 százalék). Mindkét publikációban elenyésző arányban szerepelt a határozatlan (3-3 százalék) és a visszaható (1-1 százalék) névmás; kölcsönös és birtokos névmást egyik sem tartalmazott. 


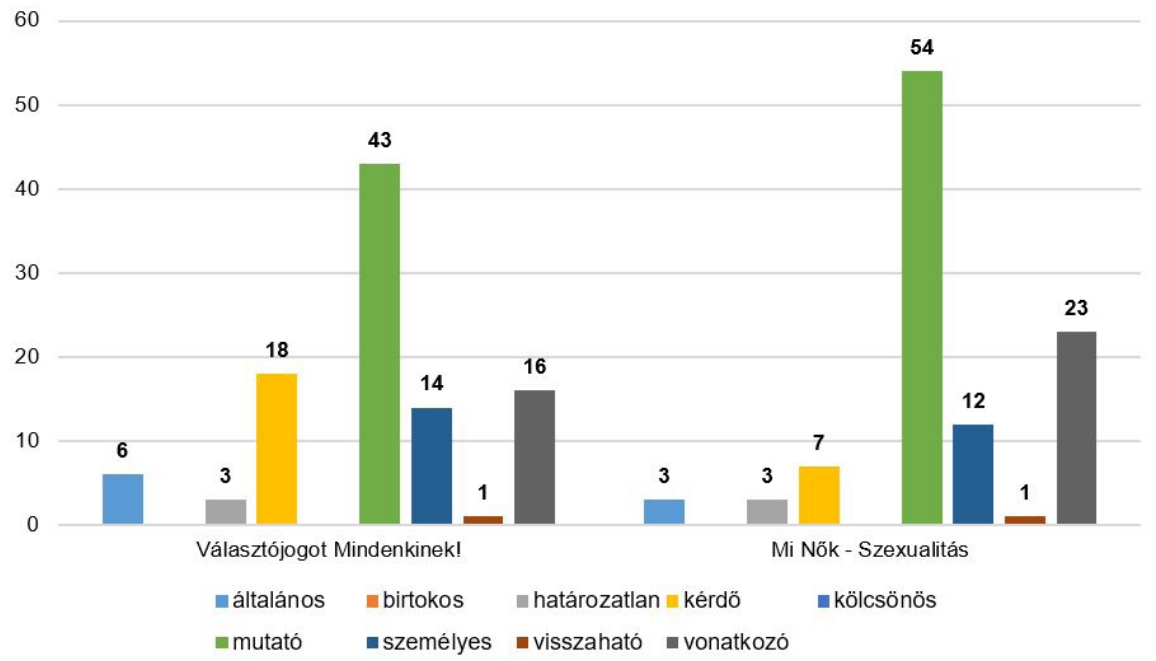

1. diagram. Névmások száma az ÉFOÉSZ két kiadványában

Az 1. diagramon látható, hogy a két publikációban milyen arányban fordulnak elő a különböző névmások. A mutató névmások gyakori alkalmazását indokolhatja az, hogy az alárendelö összetett mondatokban a távolra mutató névmások a főmondatok gyakori utalószavai, míg a közelre mutatók gyakori kapcsolóeszközök a szövegmondatok között (Jászó, 2007). Mindkét kiadványban szintén viszonylag magas arányban szerepeltek a vonatkozó névmások is. Ennek oka az lehet, hogy a vonatkozó névmások szerepe legtöbbször az, hogy az alárendelő összetett mondatok mellékmondatát a főmondathoz kapcsolják, tehát kötőszóként funkcionálnak (Keszler \& Lengyel, 2019). A mutató és vonatkozó névmás kapcsolóeszközként viselkedik például az alábbi mondatban: „Magyarországon azok a gondnokság alatt álló emberek nem szavazhatnak, akiket a bíróság kizár a szavazásból" (Báthory, Czakó \& Sallai, é.n., o.n.). A “Mi Nők - Szexualitás" (Lévai \& Nagy, 2016) című kiadványban a személyes névmásoknak közel a fele a cím miatt szerepelt. Visszaható névmások az alábbi mondatokban szerepelnek: „Vidd magaddal a személyigazolványodat, lakcímkártyádat és a választási értesítőt” (Báthory, Czakó \& Sallai, é.n., o.n.). „A kiadványok segítenek abban, hogy jobban megismerd magad” (Lévai \& Nagy, 2016:3). Az általános és a határozatlan névmások alacsony számban fordulnak elő: a két névmásban az a közös, hogy a határozatlanság fogalmi jegye mindkettöre illik. A határozatlan névmás tárgya nem meghatározott, az általános névmás pedig minden tárgyra vagy élőlényre, illetve elvont fogalomra használatos (Jászó, 2007).

A „Betegek jogai - Információ egészségügyi szolgáltatások igénybevételéhez" (Down Alapítvány, 2014a) című kiadványban az összes szó 5,9 százaléka névmás, tehát 1417-ből 85, a „Banki ügyintézés - Banki szolgáltatások igénybevétele, bankkártya használat" (Down Alapítvány, 2014b) című kiadványban pedig 1370-ből 75, ami 5,4 százalék. Elöbbiben az összes névmásból 19, utóbbiban pedig 13 az, ami mondatkezdő szóként szerepel.

A két kiadványban a mutató (59 százalék, 34 százalék), majd pedig a kérdő (15 százalék, 21 százalék) és a vonatkozó (11 százalék, 19 százalék) névmások 
szerepeltek a legnagyobb arányban. Az előbbi kiadványban a visszaható és a személyes névmások hasonló arányban ( 6 százalék és 5 százalék), a határozatlan és általános névmások pedig elenyésző arányban (2-2 százalék) voltak megtalálhatók. Utóbbi dokumentumban az általános névmások 11 százalékban, a visszaható névmások 8 százalékban, a személyes névmások 5 százalékban, a határozatlan névmások pedig 1 százalékban szerepeltek a névmások között. Kölcsönös névmás egyik dokumentumban sem volt. Az első kiadványban nem volt birtokos névmás, míg a másodikban ezek aránya 1 százalék volt.

60

50

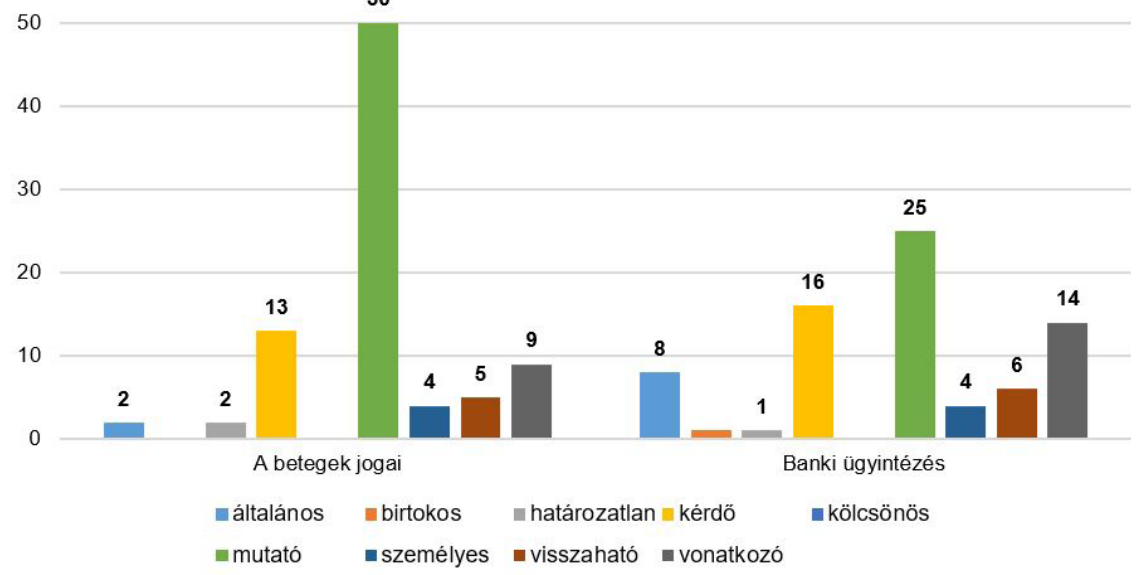

2. diagram. Névmások a Down Alapítvány két kiadványában

Mindkét kiadványban a második legtöbb alkalommal szereplő névmás a kérdő névmás. Ennek oka az lehet, hogy sokszor a fejezetek címeiben, valamint alcímeiben használják azokat, például "hol tartsam a pénzem?” és a „mire kell figyelni készpénz felvételénél?" (Down Alapítvány, 2014b).

A „Dolgozni jó! - Ismerkedés a munka világával” (Farkasné Gönczi R., 2018e) címü kiadványban a 711 szóból 25 névmás, ez 3,5 százalék. A „Mi az a kiváltás? - Ismerkedés a közösségi befogadással" (Dénesné Spitzer \& mtsai, 2019) címü kiadvány 1452 szavának 3,9 százaléka névmás, azaz összesen 57 . Az előbbi kiadvány esetében 5 alkalommal, utóbbinál pedig 11 alkalommal volt a mondatkezdő szó névmás. Tehát a névmások 20 százaléka, illetve 19 százaléka volt az első szó a mondatban, amikor az adott mondatban biztosan nem szerepelt a névmás előtt a helyettesített szó.

Mindkét kiadványban kérdő névmások szerepeltek a legtöbbször (34 százalék, 44 százalék). A kérdő névmások magas arányának lehet az oka az, hogy mindkét publikáció munkafüzet jellegü, tehát ellenőrző kérdések és feladatok is találhatók benne. llyenek például a szövegértést ellenőrző kérdések: „Mit jelent a kiváltás? (...) Hogyan segítenek a dolgozók Klárinak? (...) Miröl dönthet Klári a támogatott lakhatásban (Dénesné Spitzer \& mtsai, 2019)?” valamint „Mit jelent számodra a munka (Farkasné Gönczi, 2018c)?" A kérdések megfogalmazásakor a kérdő névmások nem hagyhatók el, illetve a kérdő névmás általában más szóval nem helyettesíthető: 
„a kérdő névmás helyettesítő szerepe eltér a többi névmásétól: helyére fogalomszó nem tehető, az a feleletben található meg" (Jászó, 2007:232).

Ezután második helyen mindkét kiadványban a mutató névmás szerepelt (20 százalék, 30 százalék). Egyik dokumentumban sem szerepelt birtokos névmás. Az első kiadványban a határozatlan névmások 16 százalékban, a személyes névmások pedig 8 százalékban fordultak elő. Visszaható, vonatkozó és általános névmások ugyanolyan csekély arányban, 4 százalékban voltak megtalálhatók. Számomra meglepő, hogy a határozatlan névmás és a személyes névmás is a középmezőnyben végzett. Míg a személyes névmás valamilyen konkrétum nevét helyettesíti, addig a határozatlan névmás közelebbröl meg nem nevezett személy vagy tárgy jelölésére szolgál. A másik füzetben a vonatkozó névmások az összes névmás 12 százalékát teszik ki, mely adódhat az alárendelő összetett mondatok használatából. Általános névmások 7 százalékban, személyes, kölcsönös és határozatlan névmások pedig 5-5-5 százalékban fordultak elő. Izgalmasnak találom, hogy a konkrét és általánosan megnevezett, illetve közelebbről meg nem nevezett személyek jelölésére szolgáló névmások közel azonos arányban fordultak elő. Visszaható névmás ebben a dokumentumban a névmásoknak csupán a 2 százaléka (3. diagram).

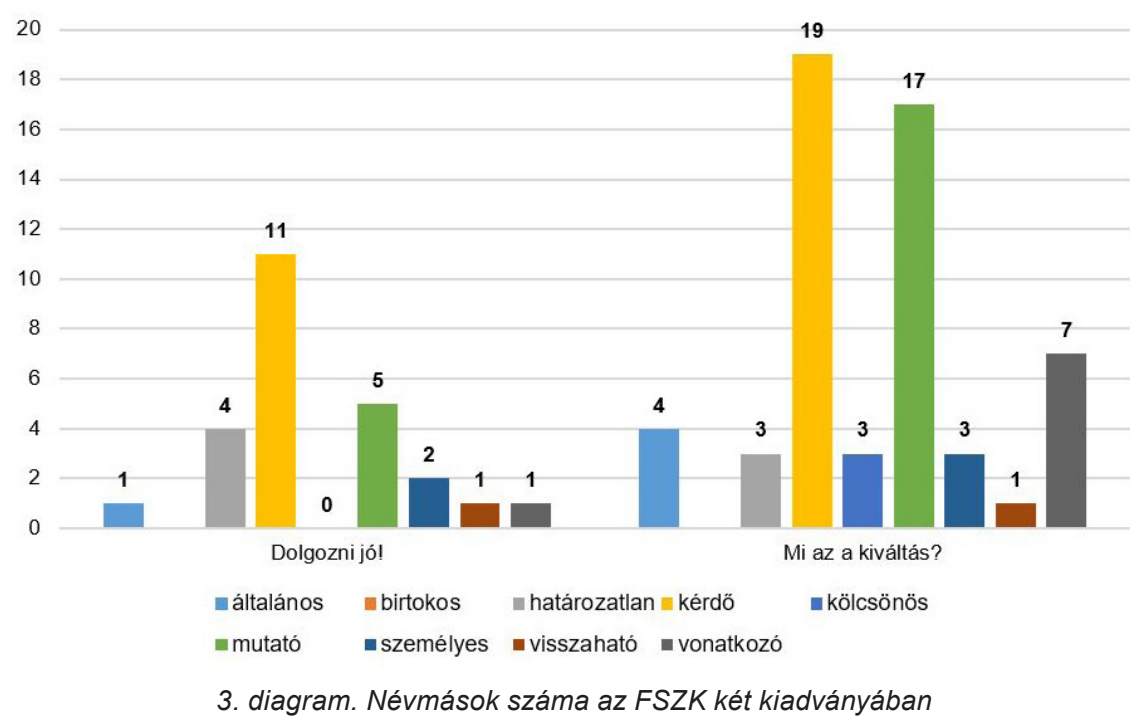

Az összes kiadványt tekintve tehát az látható, hogy arányaiban a legkevesebb névmást (3,5 százalék és 3,9 százalék) az FSZK kiadványaiban, legtöbbet pedig az ÉFOÉSZ publikációiban (6,5 százalék és 9,8 százalék) találtam.

A „Névmások használata értelmi akadályozottság esetén” című fejezetben kifejtettem, hogy a szakirodalom alapján a névmások megértése nehézséget okozhat az értelmileg akadályozott személyek számára. A könnyen érthető kommunikáció szabályrendszerei is óvatosságra intenek a névmások használatával kapcsolatban - ezt „A névmások használatára vonatkozó szabályok” címü fejezetben részleteztem. Ezért indokoltnak tartom, hogy a következő néhány bekezdésben átgondoljam azt, hogy melyek lehetnek azok a névmásfajták, amelyek használatát kerülni vagy minimalizálni lehet. Ahhoz, hogy pontos szabályokat alkossunk ebben a témában, 
mélyebb és részletesebb vizsgálatok szükségesek, de a számomra rendelkezésre álló információk egyfajta iránymutatást nyújthatnak.

A névmások fajtái helyettesítő szerepük és általános jelentés vonatkozásuk alapján csoportosíthatók. Az egyik csoport a főnevet helyettesítő vagy csak arra utaló névmások, a másik pedig a fő-, mellék- és számnevet helyettesítő, illetve ezekre utaló névmások. A kérdő és a személyes névmás az utóbbi csoportba tartozik. A mutató névmásnak a rámutató, azonosító - deiktikus - szerepén kívül vissza- és elöreutaló - fórikus - funkciója is van, valamint szintaktikai szerepe, mivel az alárendelő összetett mondatokban gyakran utalószóként szerepel. A közelre mutató névmások pedig gyakran a szövegmondatok kapcsolóeszközeiként funkcionálnak (Jászó, 2007).

A mutató névmás tehát azért fordulhat elő gyakran a szövegekben, mert sokféle funkcióval bír. Úgy gondolom, hogy a mutató névmások számát csökkenteni lehet abban az esetben, ha kerüljük az alárendelő összetett mondatok alkotását. Ehhez fontos, hogy fokozottan figyeljünk arra a szabályra (Inclusion Europe \& ÉFOÉSZ, 2009a), hogy csak egy gondolatot tartalmazó rövid mondatot használjunk, amit a vessző és kötőszavak helyett inkább lezárunk és a szöveget új mondattal folytatjuk. Emellett logikusnak tűnik a mutató névmással való vissza- és elöre utalások - tehát a fórikus funkciót ellátó mutató névmások - kerülése is. Ilyen esetekben inkább érdemes az adott mondatban megnevezni a névmással helyettesítendő szót.

A vonatkozó névmások viszonylag gyakran, az összes dokumentumban összesen 54 alkalommal fordultak elő. A vonatkozó névmás egy elöre- vagy visszautaló szó, a mondatban tehát fórikus szerepe van. Emellett szintaktikai szerepe is lehet, kötőszói funkciót is elláthat, mivel gyakran az alárendelö összetett mondatok mellékmondatát kapcsolja a fömondathoz (Jászó, 2007). A mutató névmások esetében részletezett következtetések tehát itt is érvényesek. Az alárendelö összetett mondatok kerülése, illetve az elöre- és visszautalás helyett a helyettesítendő szó mindenkori megnevezése csökkenti a névmások számát a szövegben.

Személyes névmásból 39 darabot találtam. Ez a névmás személyek, dolgok és megszemélyesített fogalmak nevét helyettesíti. Rámutató, azonosító - deiktikus funkcióval is bírhat. A személyes névmások számát csökkenteni lehet azáltal, hogy mindig megnevezzük azt, akire vagy amire gondolunk. Mivel a könnyen érthető szövegek nem személyre szabottan, egy személynek szólóan készülnek, ezért gyakori megszólítás az, hogy „te”. Ebben az esetben a névmás használatát nem lehet, és valószínüleg nem is érdemes elkerülni.

A határozatlan (25) és általános névmások (24) kicsit kevesebbszer fordultak elő a kiadványokban, mint a személyes névmások. A határozatlan névmás közelebbröl nem meghatározott, az általános névmás pedig minden élőlényre, fogalomra vagy tárgyra vonatkozó összefoglaló értelmü szó (Jászó, 2007). Ezek a névmások tehát különösen absztrakt fogalmak, túl általánosak és nem elég körülhatároltak. Érdemes tehát konkrétabb fogalmakkal helyettesíteni őket.

Visszaható névmásból összesen 15-öt találtam az elemzett szövegekben. Fontosnak tartom hangsúlyozni, hogy az ÉFOÉSZ és az FSZK 2-2 kiadványában 1-1 visszaható névmás volt, a többit a Down Alapítvány kiadványai tartalmazták. Azt fejezi ki, hogy a cselekvés a cselekvőre visszahat (Jászó, 2007). Az, hogy két kiadó publikációjában is kiadványonként csupán 1-1 darabot találtam belöle, arra enged következtetni, hogy ezek a névmások viszonylag könnyen nélkülözhetök a szövegekben. 
Kölcsönös névmást csak az FSZK kiadványában találtam, összesen 3 darabot. A kölcsönös névmás a két vagy több alany cselekvésének kölcsönösségét, egymásra hatását fejezi ki. Egyetlen ilyen névmásunk van, ez pedig az „egymás”. Úgy gondolom, hogy ez a névmás ritkán szükséges a szövegalkotáshoz. Olyan esetben is érdemes lehet használatát kerülni, amikor a névmás helyett több rövid mondatot szükséges írni, hogy a kölcsönösséget kifejezzük.

Birtokos névmás az elemzett dokumentumokban összesen egyszer fordult elő. Ez a névmás valamelyik személyben birtokot jelöl meg. Jelentést sürít azáltal, hogy a birtokviszony alkotóit, a birtokost és a birtokot egy szóval jelöli (Jászó, 2007). Mindazonáltal, hogy használatát könnyű elkerülni személyes névmás használatával, illetve a birtokos pontos megnevezésével, akár szimbolikus jelentésủ is lehetne az, hogy az értelmileg akadályozott személyeknek szóló dokumentumokban birtokos névmások összesen csak egyszer szerepeltek.

A névmásokra vonatkoztatva egy általános szabály lehet az, hogy ne használjunk névmást csak azért, mert félünk a szóismétléstöl. Ahogy arra Csató (2002) felhívja a figyelmet, a szóismétlés a könnyen érthető szövegben nem kerülendő.

\section{A kutatási kérdések vizsgálata}

Az első kutatási kérdésem az volt, hogy magyar nyelvű könnyen érthető dokumentumok tartalmaznak-e névmásokat. A feltárás során annak a három szervezetnek a kiadványaiból választottam 2-2-2 publikációt, melyek hazánkban a legtöbb könnyen érthető dokumentumot adták ki. Ezek elemzése egyértelmű választ adott a kutatási kérdésre: mindegyik kiadó mindegyik publikációja tartalmazott névmásokat.

A második kutatási kérdésemre, arra, hogy amennyiben a magyar nyelvű könynyen érthető dokumentumokban használnak névmásokat, az a szabályrendszerekben rögzített útmutatásoknak megfelelöen történik-e, nem kaptam egyértelmű választ. Mivel a szabályrendszerekben rögzített szabályok a névmásokra vonatkozóan nem elég körülhatároltak, és nem elég részletesek, ezért értelmezésük és alkalmazásuk szubjektív. Nehéz megállapítani, hogy az adott kiadvány szerzője mennyire szentelt ennek „fokozott figyelmet”, illetve mennyire járt el „körültekintően” akkor, amikor névmásokat alkalmazott a szövegekben. A vizsgált dokumentumok arányait tekintve azt találtam, hogy a legkevesebb névmást tartalmazó szövegben az összes szó 3,5 százaléka volt névmás, míg a legtöbb névmást tartalmazó írásban ez 9,8 százalék volt. Véleményem szerint ez elég nagy szórás, ami arra utal, hogy a dokumentumokban a névmások használata nem egységes szempont szerint történt. Jelentheti azt is, hogy a szerzők a szabályrendszerekben lévő utasításokat igyekeztek betartani, viszont az nem adott elég pontos információt ahhoz, hogy egységesen alkalmazhassák.

Az utolsó, harmadik kutatási kérdésem az volt, hogy amennyiben a magyar nyelvű dokumentumokban használnak névmásokat, akkor milyen jellegzetességeket lehet megfigyelni ezzel kapcsolatban. Valamint az, hogy az ugyanattól a kiadótól megjelent anyagokban a névmások használata ugyanolyan szabályszerüségek szerint történik-e. A különböző névmások előfordulásának elemzésekor nem találtam olyan sémát, ami arra utalna, hogy az ugyanattól a kiadótól megjelent kiadványokban a különböző fajtájú névmások használatára vonatkozó konkrét szabályokat alkalmaztak 
volna. Az összes kiadványt tekintve viszont általánosan megfigyelhető jellegzetesség volt a mutató, a kérdő és a vonatkozó névmások magas aránya, illetve a kölcsönös és a birtokos névmások használatának ritkasága.

\section{ÖsSZEFOGLALÁs}

Tanulmányomban a névmások használatát vizsgáltam könnyen érthető információkat tartalmazó dokumentumokban. Az elméleti részt összegezve elmondható, hogy ahhoz, hogy a könnyen érthető kommunikációval készült információkat a befogadó dekódolni tudja, fontos, hogy legyenek ismereteink az ő nyelvi funkcióiról. Ehhez fontos az üzenet célcsoportjának a lehető legpontosabb meghatározása és megismerése. Ezt követően állapítható meg, hogy az információt milyen formában és milyen nyelvi kóddal érdemes eljuttatni hozzá.

A tapasztalatokat összegezve úgy gondolom, hogy fontos lenne a magyar nyelvű szabályrendszerekben pontosítani a névmások használatára vonatkozó szabályokat, hiszen a jelenlegiek szubjektíven értelmezhetők és nem elég részletesek. Véleményem szerint szükséges, hogy ezen szabályokat módosítsuk, miközben hangsúlyozzuk, hogy mindig az aktuális célcsoport szükségleteit fontos figyelembe venni.

A névmásokra vonatkozó szabályok pontosításához fontos lenne további kutatásokat végezni. Hasznos lenne több szempontból elemezni a szövegekben található névmásokat. Azt is vizsgálni kellene, hogy a dokumentumokban a névmások által helyettesített szó hol van megnevezve a névmáshoz képest, hiszen ez is befolyásolja azt, hogy mennyire könnyủ értelmezni a névmást. Emellett szükséges lenne felmérni azt is, hogy a névmásoknak pontosan mekkora hányadát hozzák létre az összetett mondatok, különös tekintettel az alárendelő összetett mondatokra. Emellett indokolt lenne egy gyakorlati kutatás is, amiben különböző nyelvi funkciókkal bíró értelmileg akadályozott személyek felmérése során kideríthetnénk, hogy melyek azok a névmások, amelyek értelmezése a szövegben egyszerübb. Emellett azt is, hogy amennyiben alkalmazunk névmásokat a szövegben, hogyan kell ezeket elhelyeznünk ahhoz, hogy a lehető legegyszerübben és legegyértelmübben értelmezhetők legyenek.

A könnyen érthető kommunikációval készült szövegek által hozzáférhetővé válhatnak az információk az értelmileg sérült személyek számára is. Az információ letisztult, egyszerü áramoltatása egyfajta akadálymentesítés, befogadó környezet teremtése amellett, hogy olyan alapvető emberi jogok biztosítását is szolgálja, mint az önálló döntéshozatal, az önrendelkezés és a társadalmi részvétel (Horváth, 2020; Gruiz, é.n.; Farkasné Gönczi, 2018a). Ezek a hatások viszont csak akkor tudnak érvényesülni, ha az információ valóban hozzáférhetővé válik a célcsoport számára. Ehhez az szükséges, hogy a könnyen érthető szövegeket és az ezeket szabályozó rendszereket folyamatosan monitorozzuk, ellenőrizzük, hogy az érintett emberek számára valóban a legideálisabbak-e. 


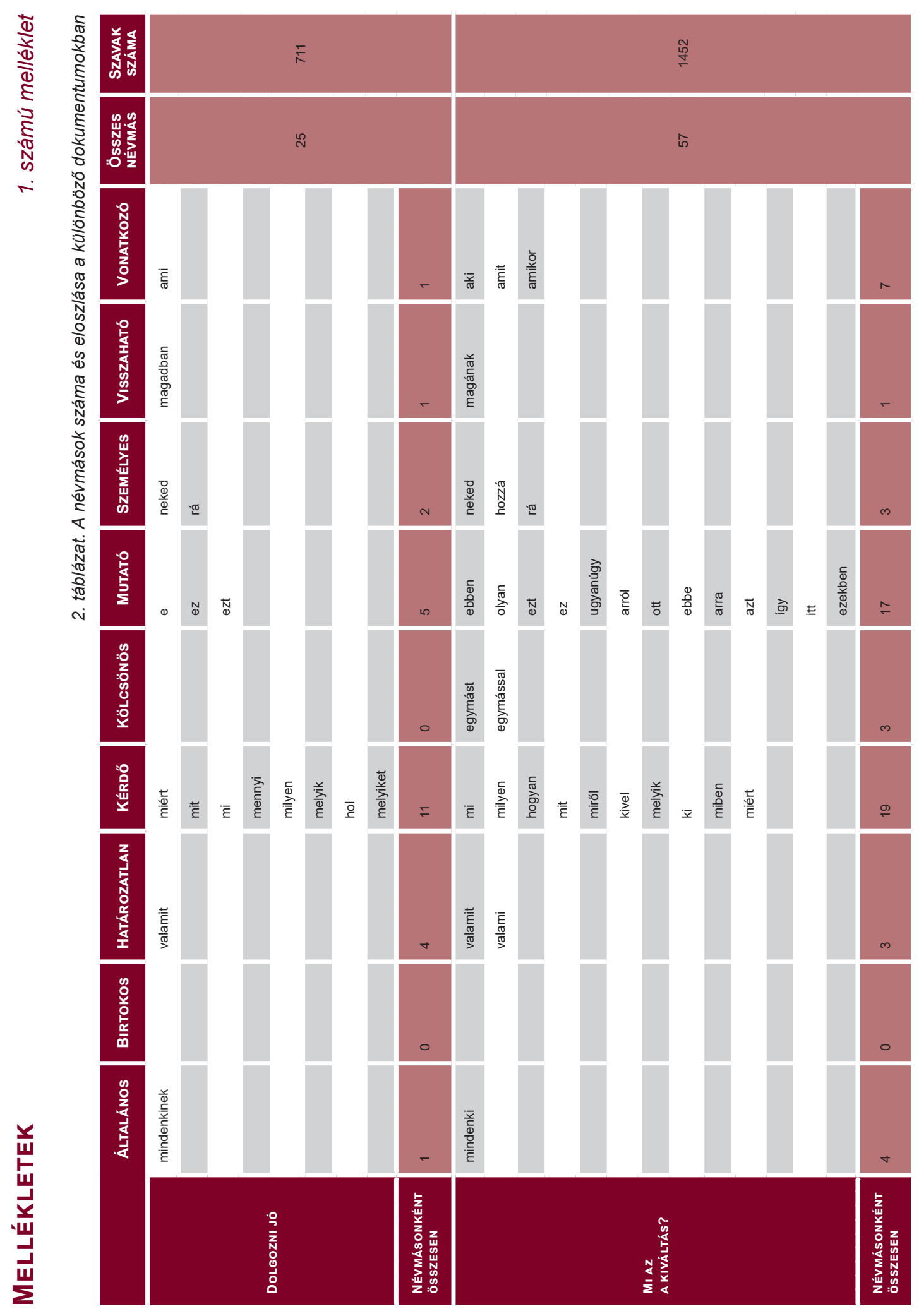




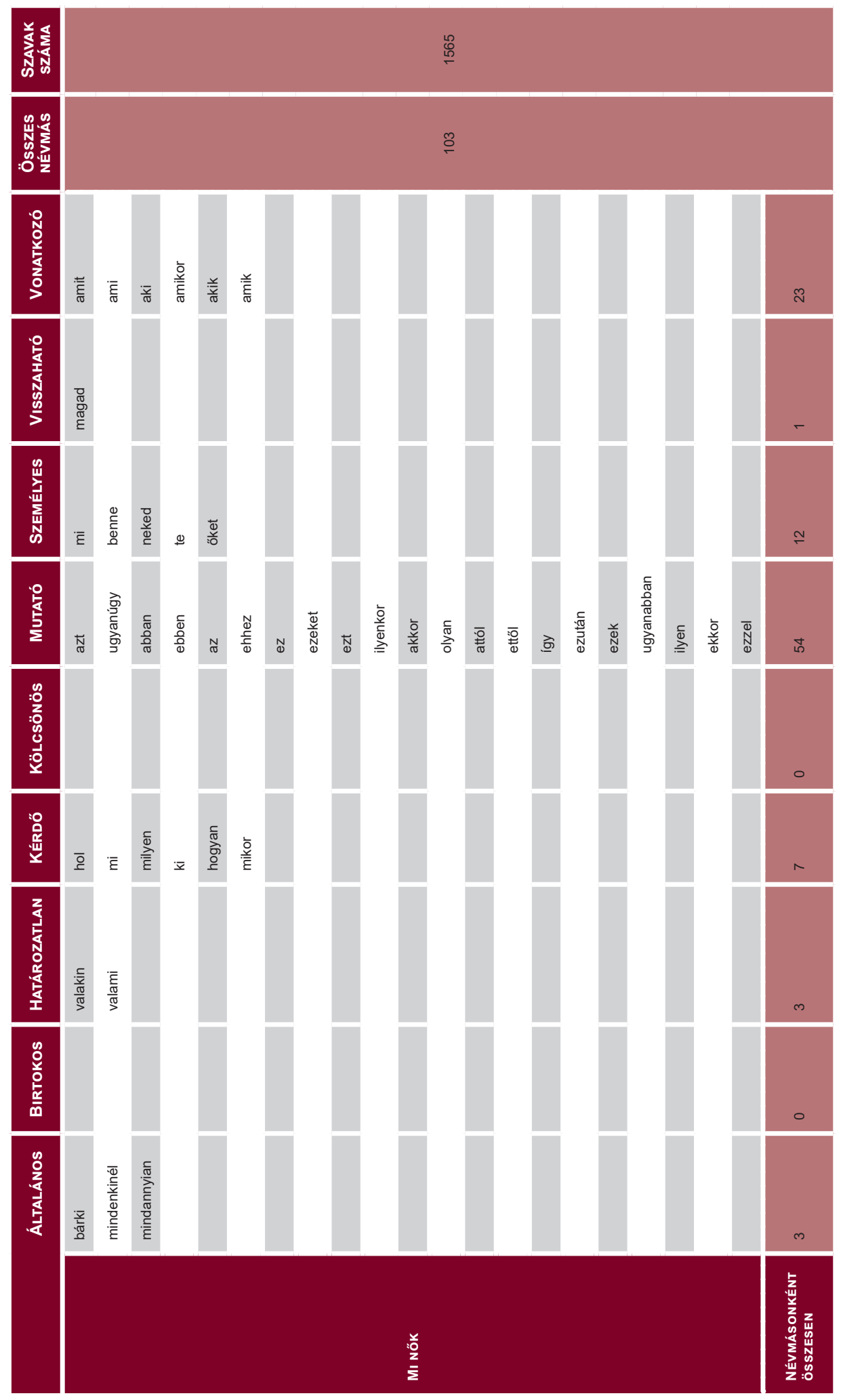




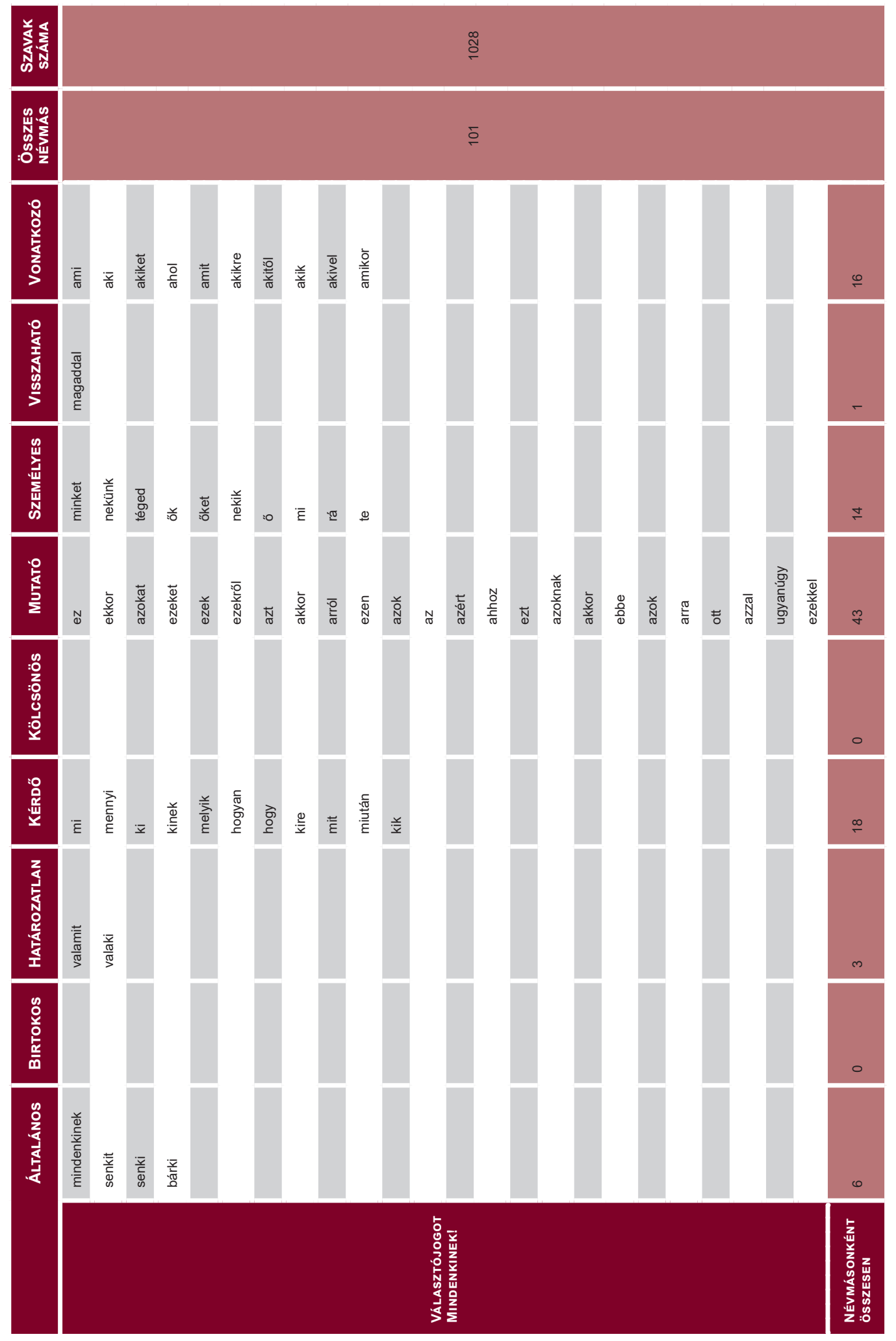




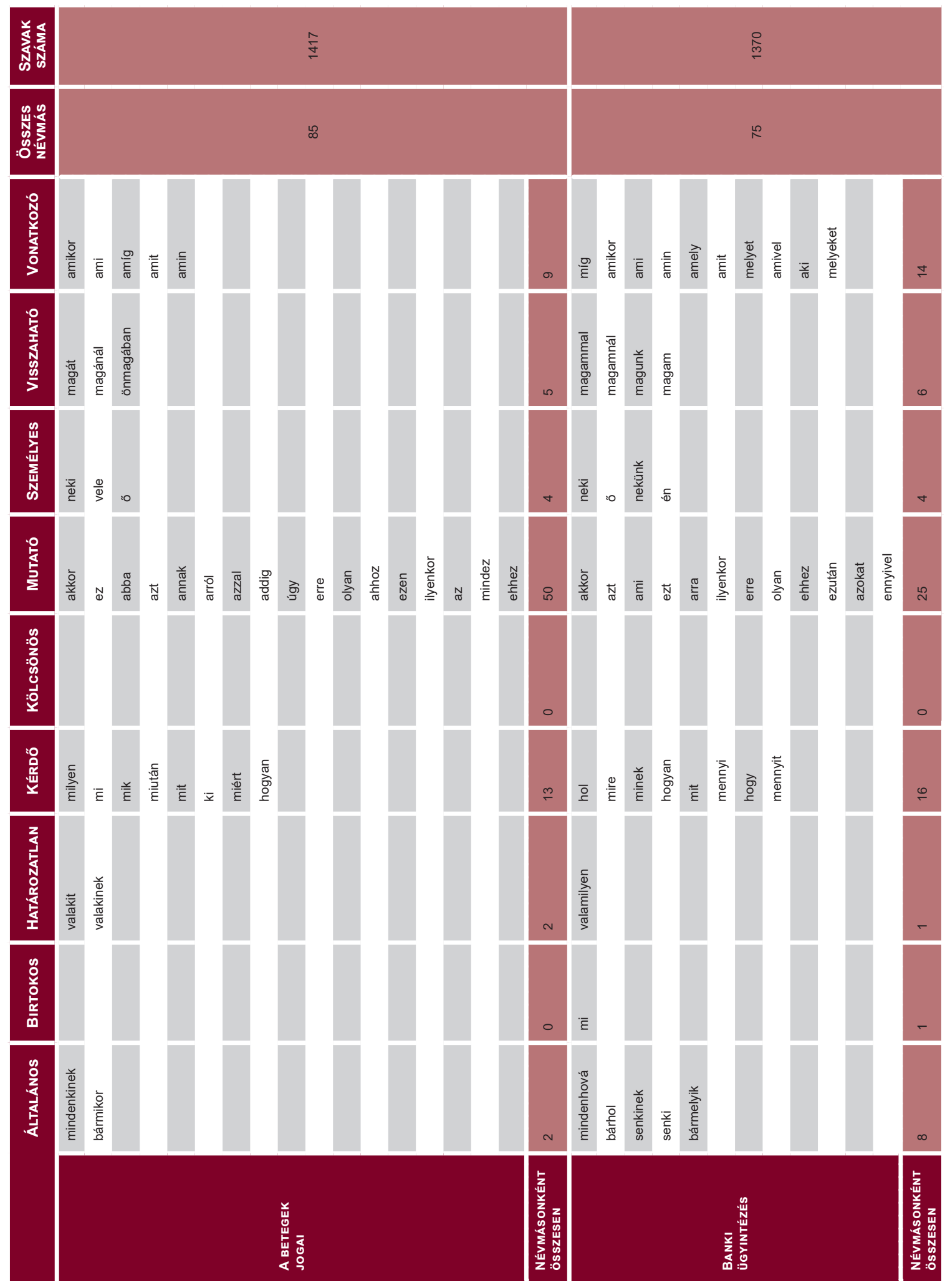




\section{Irodalom}

1998. évi XXVI törvény a fogyatékos személyek jogairól és esélyegyenlőségük biztosításáról a Fogyatékossággal élő személyek jogairól szóló ENSZ egyezmény, 2006

A magyar nyelv értelmező szótára (2016). https://mek.oszk.hu/adatbazis/magyar-nyelv-ertelmezo-szotara/elolap.php Letöltés ideje: 2021.01.27.

Almási M. (2016). A láthatatlan hatalmak. Magyar tudomány. Magyar Tudományos Akadémia, Budapest. http://www.matud.iif.hu/2016/06/06.htm Letöltés ideje: 2021.01.26.

Avornicului M., Seer L. \& Benedek B. (2006). Identitás a XXI. század információs társadalmában, az internet hatásai. http://publikaciotar.repozitorium.uni-bge.hu/1563/ Letöltés ideje: 2020.03.01.

Baker V., Oldnall L., Birkett E., McCluskey G. \&, Morris J. (2010). Adults With Learning Disabilities (ADL): Royal College of Speech and Language Therapists Position Paper. RCSLT, London.

Báthory N., Czakó T. \& Sallai I. (é.n.). Választójogot Mindenkinek! - Európai Parlamenti választások 2019. ÉFOÉSZ, Budapest.

Chinn, D. \& Homeyard, C. (2017). Easy read and accessible information for people with intellectual disabilities: Is it worth it? A meta-narrative literature review. Health Expectations, 2017.201189-1200. https://doi.org/10.1111/hex.12520

Csató Zs. (szerk.) (2002). Egyszerűen, érthetően: útmutató könnyen érthető tájékoztatók készítéséhez. ÉFOÉSZ, Budapest.

Dénesné Spitzer É., Farkasné Gönczi R., Kiss E., dr Kissné Huszár A. \& Nagy L. (2019). Mi az a kiváltás? - Ismerkedés a közösségi befogadással. FSZK, Budapest.

Down Alapítvány (2014a). A betegek jogai - Információ egészségügyi szolgáltatások igénybevételéhez. Down Alapítvány, Budapest.

Down Alapítvány (2014b). Banki ügyintézés - Banki szolgáltatások igénybevétele, bankkártya használat. Down Alapítvány, Budapest.

ELTE Bárczi Gusztáv Gyógypedagógiai Kar (2019). Gyógypedagógia alapképzési (Ba) szak. https://barczi.elte.hu/media/cc/1d/41da9e79014a4ff7b7d7c972cee66e78880a22cb8de848b8ae8af2a8e8f2/Gyogypedagogia_alapkepzes_BA_2019.pdf Letöltés ideje: 2021.01.26.

Farkasné Gönczi R. \& Graf-Jaksa É. (2009). Könnyen érthető kommunikáció. In Pandula A., Szatmári P., Vincze T., Farkasné Gönczi R. \& Graf-Jaksa É. (szerk.), Kommunikációs és információs technológiák és fogyatékosságügy. ELTE Bárczi Gusztáv Gyógypedagógiai Kar, Budapest. 80-100.

Farkasné Gönczi R. (2018a). A könnyen érthető kommunikáció fogalma és szabályrendszere nemzetközi és hazai példák, illetve magyar tapasztalati szakértők javaslatai alapján. Gyógypedagógiai Szemle, 46.1:64-76.

Farkasné Gönczi R. (2018b). Dolgozni jó! - Segédlet a füzetsorozat használatához. FSZK, Budapest.

Farkasné Gönczi R. (2018c). Dolgozni jó! - Ismerkedés a munka világával. FSZK, Budapest.

Friedman, L.; Lorang, E. \& Sterling, A. (2019). The Use of Demonstratives and Personal Pronouns in Fragile X Syndrome and Autism Spectrum Disorder. Clinical Linguistics \& Phonetics, 33.5:420-436. https://doi.org/10.1080/02699206.2018.1536727

Gruiz K. (évszám nélkül). Hogyan készítsünk könnyen érthető segédanyagot? - Irányelvek. Down Alapítvány, Budapest.

Gruiz K. (szerk.) (2009). Mentális akadálymentesítés. Elvek, etika, gyakorlat. Down Alapítvány, Budapest.

Hegedủs H. (2020). A kevesebb néha több. Fogyatékosság és Társadalom 2020.1: 63-73. https://doi.org/10.31287/FT.hu.2020.1.7

Horváth P. L. (2017). Önrendelkezés és könnyen érthető kommunikáció - a KÉK hazai fejlesztésének lehetőségei. In Bogdán B., Cserti-Szauer Cs., Katona V. \& Sándor A. (szerk.), Befogadás és önrendelkezés. Absztraktkötet. ELTE Bárczi Gusztáv Gyógypedagógiai Kar, Budapest. 23-27.

Horváth P. L. (2019). A könnyen érthető kommunikáció meghatározása. Carissimi, X.2:8-10.

Horváth P. L. (2020). A könnyen érthető kommunikációs képzési programok képzésfejlesztésének története Magyarországon a fogyatékossággal élő személyek jogairól szóló ENSZ egyezmény tükrében. (Doktori értekezés.) Eszterházy Károly Egyetem Neveléstudományi Doktori Iskola, Eger.

Inclusion Europe \& ÉFOÉSZ (2009a). Információt mindenkinek! A könnyen érthető kommunikáció európai alapelvei. Inclusion Europe - ÉFOÉSZ, Brüsszel - Budapest. 
Inclusion Europe \& ÉFOÉSZ (2009b). Ne írjon nekünk, nélkülünk! - Hogyan vonjunk be értelmi fogyatékossággal élő embereket könnyen érthető szövegek készitésébe? Inclusion Europe - ÉFOÉSZ, Brüsszel - Budapest.

Inclusion Europe \& ÉFOÉSZ (2009c). Az egész életen át tartó tanulás oktatóinak képzése. Inclusion Europe - ÉFOÉSZ, Brüsszel - Budapest.

Jászó A. (szerk.) (2007). A magyar nyelv könyve. Trezor Kiadó, Budapest.

Kerner Zs. (2020). Az új elit nem vásárol drága dolgokat, de sokkal zártabb, mint a régi valaha volt. https://24.hu/kozelet/2020/01/12/elit-toke-currid-halkett/ Letöltés ideje: 2021.01.26.

Keszler B. \& Lengyel K. (2019). Kis magyar grammatika. Akadémiai Kiadó, Budapest. https://doi. org/10.1556/9789630599641

Lévai E. \& Nagy E. (2016). Mi Nők - Szexualitás. ÉFOÉSZ, Budapest.

Magyar Gyógypedagógusok Egyesülete (2011): Etikai kódex. http://www.magye-1972.hu/iratszekreny/83-dokumentumok/116-etikai-kodex Letöltés ideje: 2020.03.10.

Nomura, M., Nielsen, G. S. \& Tronbacke, B. (2010). Guidelines for easy-to-read materials. IFLA/ Library Services to People with Special Needs Section, Hága.

Rácz E. \& Takács E. (1974). Kis magyar nyelvtan. Gondolat Kiadó, Budapest.

Sanoudaki, E. \& Spyridoula V. (2014). Pronoun Comprehension in Individuals With Down Syndrome: Deviance or Delay? Journal of Speech Language and Hearing Research, 57.4:1442-1452. https://doi.org/10.1044/2014_JSLHR-L-13-0035

Subosits I. (1994). Az értelmi fogyatékosok beszédének nyelvi funkciói. In Radványi K. (szerk.), Az értelmileg akadályozottak kommunikációja I. - Szöveggyüjtemény. Bárczi Gusztáv Gyógypedagógiai Tanárképző Főiskola, Budapest.

Tar É. (2013). A fonológiai profil feltárásának szerepe Down-szindrómás gyermekek logopédiai ellátásában. Gyógypedagógiai Szemle, 41.4:254-260.

Watzlawick, P., Beavin, J. \& Jackson D. D. (2003). A kommunikáció két axiómája. In Horányi Özséb (szerk.), Kommunikáció I. General Press, Budapest. 98-101.

\section{Többet szeretne tudni}

a hozzáférhető információval kapcsolatos

kutatási eredményekről?

Jelentkezzen a 2021. augusztus 30-án

és 31-én online megrendezésre

kerülő svájci, második nemzet-

közi „KLAARA” konferenciára

2021. augusztus 5 -ig.

Az első KLAARA

konferencia anyagait

itt érheti el.
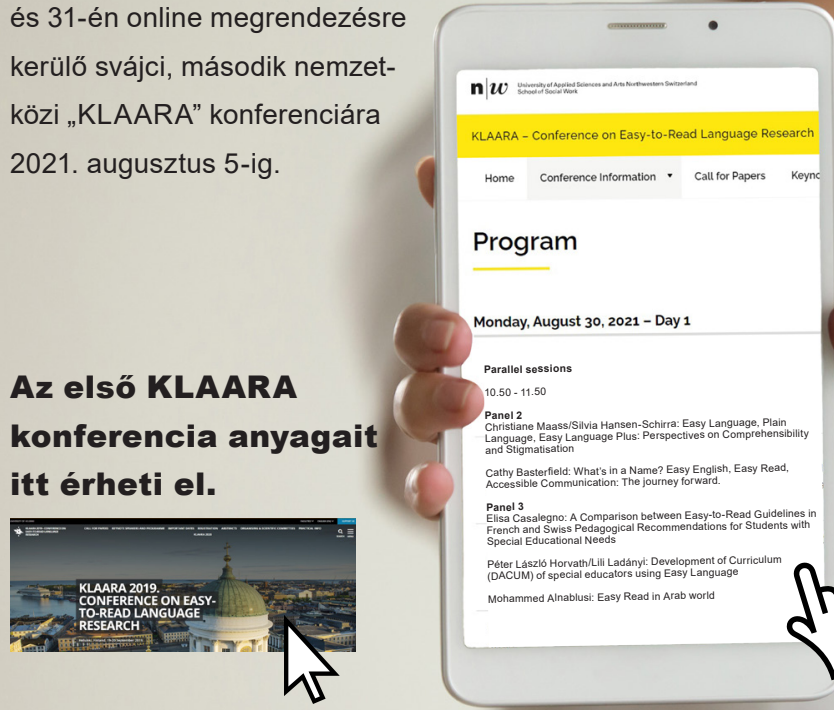

Program

Monday, August 30, 2021 - Day 1

$10.50-11.50$

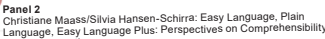

Language, Easy Language Plus: Perspectives on Comprehensib
and Stigmatisation

Cathy Basterfield: Whats in a Name? Easy English, Easy Read
Accessible Communication: The journey forward.

Panel 3
Elisa Casalegno: A Comparison between Easy-to-Read Guidelines in
French and Swiss Pedagogical Recommendations for Students with
S

French and Swiss Pedagogic
Special Educational Needs

Péter Lászzlo Horvath'Lili Ladányl: Development of Curr
(DACUM) of special educators using Easy Language

Mohammed Alnablusi: Easy Read in Arab world

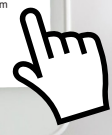




\section{Könnyen érthető kommunikáció értelmi sérült személyekkel. A mondatok használatának vizsgálata könnyen érthető információkat tartalmazó doku- mentumokban}

\begin{abstract}
A tanulmány középpontjában a könnyen érthető kommunikáció áll, melynek alkalmazása és felhasználása folyamatos monitorozást igényel annak érdekében, hogy minél eredményesebb lehessen. Az eredményességet nem csupán a már elkészült könnyen érthetö dokumentumok lektorálása szolgálja, hanem ezen dokumentumok alapját képező szabályrendszerek vizsgálata, finomhangolása is szükségszerü.

A könnyen érthető kommunikációról, annak szabályrendszereiről és célcsoportjának mondathasználati jellemzöiröl szóló rövid elméleti összefoglaló után négy, az Inclusion Europe által kiadott „Európa nekünk” címü könnyen érthetö hírlevelének mondatai kerülnek górcső alá.

Az elméleti jellegủ kutatómunkában az Inclusion Europe „Információ mindenkinek - A könnyen érthető kommunikáció európai alapelvei" címủ szabályrendszerét alapul véve arról gyüjtünk információkat, hogy a mintául szolgáló kiadványok mondataiban a mondathasználatra vonatkozó szabályok érvényesülnek-e, illetve a mondatok alkalmazása milyen mintázatokat mutat. A szabálypontokat külön-külön áttekintve, majd azok együttes érvényesülésére fókuszálva is megvizsgáltuk a mondatokat, a szabályrendszer betarthatóságának következetességére, illetve következetlenségére utaló jeleket keresve.

Az eredmények elemzése látható tette, hogy a vizsgált kiadványok nagymértékben törekednek a szabálykövetésre, ám az attól való eltérések is jelentősek. Az eredmények alapján lehetőség nyilik a könnyen érthető mondat alkotására irányuló szabályok pontosítására és kiegészitésére.
\end{abstract}

Kulcsszavak: könnyen érthető kommunikáció, szabályrendszer, mondatok, értelmi akadályozottság

\section{BEVEZETÉS}

Jelen tanulmány fókuszában a könnyen érthető kommunikáció (továbbiakban: KÉK) mint az értelmi sérült személyek kommunikációját akadálymentesítő eszköz témaköre áll. A könnyen érthető kommunikáció létjogosultságát az értelmi sérült személyek önálló életvitelhez, önálló döntéshozatalhoz, valamint az ezen jogok gyakorlásához szükséges információhoz való hozzáférés joga indokolja. A jogaik gyakorlásával a társadalomhoz való tartozásuk megerősödik, amely jelentősen kedvez a társadalom fejlődésének mind az emberi, a szociális és a gazdasági fejlődés terén (fogyatékosságügyi ENSZ egyezmény, 2006).

A könnyen érthető információforrások tára egyre bővebb és színvonalasabb, azonban rendszerszintű, közismert, szerteágazó megjelenése még kialakulóban van (Horváth, 2020). Ahhoz, hogy a célcsoport számára rendelkezésre álló információk akadálymentesítése valóban megvalósuljon, elengedhetetlen, hogy a könnyen érthető információforrások és az azokat szabályozó rendszerek hatékonyságát rendsze- 
resen ellenőrizzük, illetve finomítsuk annak érdekében, hogy az értelmi sérült emberek igényeihez alkalmazkodva valóban célba tudjon érni az általuk közvetített üzenet.

E tanulmányban a célom, hogy közvetetten segítsem a könnyen érthető dokumentumok minél hatékonyabb elkészítését. A már korábban elkészült könnyen érthető szövegek tanulmányozásával egységes szabályrendszerük egy szegmensének megvalósulását és a megvalósulásának következetességét járom körül. A vizsgálat a kiválasztott kiadványok mondataira irányul. Feladatomnak tekintem, hogy ebben a témában egy olyan feltárást végezzek, amely alapot adhat további elméleti és gyakorlati kutatásokhoz.

Tekintettel arra, hogy a Fogyatékosság és Társadalom címü folyóirat jelen tematikus számában több cikk is foglalkozik a könnyen érthető kommunikáció fogalmával, funkcióival, célcsoportjaival, ezért az alapozáshoz szükséges e témaköröket ebben a tanulmányban nem érintem. Keszey Borbála tanulmányában kerülnek bemutatásra a jelenleg elérhető magyar nyelvű szabályrendszerek és a könnyen érthető dokumentumok készítésekor felmerülő dilemmák is. A tanulmány első felében a szabályrendszerek mondatokra vonatkozó elemeit mutatom be. Mivel a könnyen érthetö információk készítéséhez nagyon fontos, hogy minél többet tudjunk a célcsoport nyelvi szintjéröl, kitérek arra, hogy a kapcsolódó szakirodalmak szerint milyen ismereteink vannak az értelmi sérült személyek mondathasználatáról.

A tanulmány második felében négy könnyen érthető hírlevél elemzését végzem, a mondatokra vonatkozó szabályok tényleges érvényesítése szempontjából. Ismertetem a kutatási kérdéseket, majd röviden vázolom azon könnyen érthető kiadványok tartalmát, amelyek a mintát alkotják. Összefoglalom, hogy milyen folyamat vezetett el a vizsgálatok eredményeihez. Tanulmányozom, hogy a mondatalkotásra vonatkozó szabályokat hogyan alkalmazzák - először a szabályokat külön-külön áttekintve, majd azok együttes érvényesülésére fókuszálva. Külön figyelmet fordítok azokra az esetekre, amelyekben szabálytól való eltérés jelentkezik, amellyel a célom az, hogy a szabályoktól való eltérések okaira is választ találjak.

\section{A mondatokra vonatkozó szabályok}

A következőkben áttekintem, hogy a különböző magyar nyelvü szabályrendszerek milyen mondatokra vonatkozó szabályokat tartalmaznak.

$A z$ „Egyszerűen, érthetően - Útmutató a könnyen érthető kommunikáció készítéséhez" címủ kiadványban a következő mondatokra irányuló szabályokat tüntetik fel:

1. "Lehetöleg rövid mondatokat írjunk."

2. „Mondatonként egy fő gondolatot fogalmazzunk meg. Egy gondolatnál vagy témánál többet ne zsúfoljunk egy mondatba."

3. „Minden mondatot külön sorba írjunk. Ha ez nem lehetséges, a részmondatokat írjuk külön sorba. A lényeg, hogy egy-egy sorban összetartozó elemek legyenek (így az olvasás szünetei megfelelnek a természetes beszéd szüneteinek).

4. „Egy mondat mindenképpen egy oldalra kerüljön (Csató, 2002:14-17).

Olyan javaslattal is találkozhatunk, amely nem kifejezetten a mondatokra irányul, viszont befolyással lehet az írásképre: „Ne válasszunk el szavakat (Csató, 2002:17.)” Ezt a szabályt azért tartom fontosnak megemlíteni, mert a szavak elválasztása 
semmiképpen nem az olvasás természetes szünetének megfelelően szakítja meg a mondatot.

A „Hogyan készítsünk könnyen érthető segédanyagot? - Irányelvek” című kiadványban a következő mondatokra vonatkozó szabályok találhatóak:

1. „Igyekezzünk kerülni az alárendelt szerkezetü összetett mondatok használatát."

2. „Lehetöleg minden új mondatot új sorban kezdjünk."

3. „Igyekezzünk rövid mondatokat alkalmazni. Ez megoldható például úgy, hogy egy gondolatot egy mondatban mondunk el" (Gruiz, é.n.:2-5.).

Ez az útmutató is javasolja a szavak elválasztásának elkerülését (Gruiz, é.n.).

Az „Információ mindenkinek - A könnyen érthető kommunikáció európai alapelvei” címủ kiadványban a mondatokra irányuló szabályoknak külön fejezetet szenteltek:

1. „Minden mondatot kezdjünk új sorban.”

2. „Használjunk rövid mondatokat. Rövid lesz a mondatunk, ha egy mondatba csak egy gondolatot írunk; és mielőtt új gondolatba kezdünk, lezárjuk a mondatunkat, vessző és kötőszavak használata helyett."

3. „Ha lehet, 1 mondatot 1 sorba írjunk. Ha egy mondatot 2 sorba kell írnunk, ott vágjuk ketté, ahol szünetet lehet tartani az olvasásban."

4. „Inkább pozitív tartalmú mondatokat használjunk, a negatív tartalmú helyett. Például ez egy pozitív tartalmú mondat: Itt kell maradnod addig, amíg a találkozó véget nem ér. Ez pedig egy negatív tartalmú mondat: A találkozó végéig nem mehetsz el."

5. „Kerüljük a szavak elválasztását. A sor végén, kötőjellel elválasztott szavak nem könnyen érthetőek" (Inclusion Europe \& ÉFOÉSZ, 2009: 11-17.).

A három szabályrendszer egyhangúan javasolja a mondatok rövidségét, az új mondatok új sorban való kezdését és a szóelválasztás kerülését. A felsorolt szabályok jól követhetőek, megfelelő rugalmasság mellett betarthatóak. Azonban előfordulhat, hogy az alkalmazásukkal olyan problémát okozunk, amely miatt esetleg új szabályra lehet szükség. Például az új mondatok új sorba írása a szöveg hosszúságának növelését eredményezheti, a hosszú szöveg pedig nehezíti a követhetöséget, érthetőséget. Ennek a problémának az eshetőségét az „Egyszerüen, érthetően - Útmutató a könnyen érthető kommunikáció készítéséhez” és az „Információ mindenkinek - A könnyen érthető kommunikáció európai alapelvei” című kiadvány is megemlíti. llyen esetben mindkét útmutató a szöveg több rövidebb részre osztását tanácsolja (Csató, 2002; Inclusion Europe \& ÉFOÉSZ, 2009).

\section{A mondatok használata értelmi sérült személyeknél}

A közlönek a könnyen érthető üzenetét az értelmi sérült személy nyelvi kompetencia-szintjéhez igazodva kell létrehoznia, melyhez elengedhetetlen, hogy a közlő ismerje a befogadó nyelvi kompetenciájának jellemzőit. Ha tudjuk, hogy kinek készítjük a tartalmat, akkor ezek a jellemzők könnyen megismerhetők. Gyakori azonban, hogy nincs elég konkrét információnk a befogadók nyelvi kompetenciájáról. Ilyenkor az üzenetet azon előzetes ismeretek alapján tudjuk kódolni, amelyeket az általunk elképzelt célcsoport nyelvi kompetenciájáról korábban szereztünk (Horváth, 2019b). Ez azt jelenti, hogy az értelmi sérült személyek nyelvi kompetenciáinak általános 
jellemzőire érdemes fókuszálni. Témaválasztásomhoz kapcsolódva jelen fejezetben a mondatok olvasásával összefüggö, létező ismeretekre fókuszálok.

Az értelmileg akadályozott személyek viszonylag jó mechanikus emlékezettel rendelkezhetnek, melynek köszönhetően az olvasás technikáját el tudják sajátítani. Ugyanakkor a szöveg hibátlan elolvasása nem garantálja azt, hogy az olvasó meg is érti a szöveg lényegét. A mondatok olvasása során a szavakat és azoknak jelentését meg kell jegyezni. Gyakori probléma, hogy a lassú olvasási tempó miatt sok idő eltelik a következő szó elolvasásáig, ezért a már addig olvasott szavakat elfelejthetik. A felejtés oka azonban nemcsak a lassú tempó, hanem a munkamemória alacsonyabb kapacitása is. Az értelmi sérült személyekre jellemző lehet az alacsony koncentrációs képesség, az ingadozó figyelem, illetve a lényegre való fókuszálás nehézsége. A célcsoport tagjai számára a szövegben való tájékozódás, a balról jobbra, fentről lefelé való haladás nagyobb erőfeszítést igényel (Lányiné, 2017; Mede, 2010; Szabó, 2006). Ezeket a nehézségeket súlyosbítaná az, ha az olvasó előtt hosszú mondatok sorakoznának. Ezzel szemben a rövid mondatok kevésbé terhelik a munkamemóriát, a koncentrációt és a tájékozódást. A mondatok hosszúsága meghatározza a sor hosszúságát is. Fontos tehát megtalálnunk azt a megfelelö mondat- és sorhosszúságot, amely után a következő sor elejére könnyedén vissza lehet találni (Horváth, 2019b).

A tapasztalatok szerint a mondatok olvasása során gondot okozhat felismerni a szavak között lévő grammatikai viszonyokat. A szöveg olvasása során pedig a mondatok közötti összefüggés észlelése okozhat nehézséget. Segíti mind a mondatok, mind a szöveg értelmezését, ha a tartalomhoz szorosan kapcsolódó, magyarázó erejü képeket, adott esetben eseményképeket kapcsolunk (Szabó, 2006).

Láthatjuk tehát, mennyire fontos, hogy a közlönek hiteles ismeretei legyenek a befogadó nyelvi kompetenciájának jellemzőiről. Az információhoz való hozzáférés nemcsak a befogadó adottságaitól és készségeitől függ, hanem attól is, hogy a közlő mennyire tud igazodni a befogadó nyelvi szintjéhez (Horváth, 2020).

\section{A VIZSGÁLAT}

Fontos, hogy a könnyen érthető üzenet készítését támogató szabályrendszerek tudományos bizonyítékon alapuljanak.

\section{Kutatási kérdések}

Arra keresem a választ, hogy a vizsgált magyar nyelvü, könnyen érthető kiadványokban az alkotók hogyan érvényesítik a szabályrendszer mondatokra irányuló útmutatásait.

1. A vizsgált dokumentumban az alkalmazott szabályrendszerben rögzített, mondatokra vonatkozó szabályoknak megfelelöen történik-e a mondatok alkotása?

2. Amennyiben a vizsgált dokumentumban az alkalmazott szabályrendszerben rögzített, mondatokra vonatkozó szabályoktól való eltérés tapasztalható, akkor az eltérésben felfedezhető-e hasonlóság, illetve következetesség? 
3. Amennyiben a vizsgált dokumentumban a szabályrendszerben rögzített, mondatokra vonatkozó szabályoktól való eltérések történnek, indokoltnak tünnek-e az eltérések?

4. Amennyiben a vizsgált dokumentumban a szabályrendszerben rögzített, mondatokra vonatkozó szabályoktól való eltérések történnek, mivel magyarázható az eltérés?

5. Milyen jellegzetességeket lehet megfigyelni a vizsgált dokumentumban megfogalmazott mondatok esetében?

\section{A mintához választott kiadványok}

A vizsgálathoz a nem valószínűségi mintavételi eljárások közül a szakértői mintavételi eljárást, valamint a véletlenszerű mintavételi eljárást választottam. $A$ könnyen érthető információforrások közül olyan publikációkra esett a választásom, amelyek a jelenlegi legfrissebb és leginkább alkalmazott, magyar nyelven elérhető szabályrendszer útmutatása alapján készültek el. Ez az „Információ mindenkinek - A könynyen érthető kommunikáció európai alapelvei” szabályrendszer. Az ilyen típusú kiadványok közül véletlenszerüen az Inclusion Europe által kiadott „Európa Nekünk” című hírlevél négy 2019-es számát emeltem be a vizsgálatba. Azért éppen ezeket választottam, mert a szabályrendszert is ez a szervezet alkotta, így joggal feltételezhető, hogy a szabályrendszer alkotójának képviselői betartják a saját szabályrendszerüket. A minta nagyságára és kiválasztásának speciális szempontjaira figyelemmel ezek a kutatási eredmények természetesen nem lesznek általános érvényűek, azonban egyes tendenciák mégis kirajzolódnak.

Az „Európa Nekünk” célja, hogy az önérvényesítéssel kapcsolatos európai híreket közölje. A kiadványok szerkezeti felépítése hasonló. Mind a négy szám tartalomjegyzékkel és egy bevezető, a hírlevél fő témáit összefoglaló résszel kezdődik. A fő részben fejezetekre bontva fejtik ki az aktuális témákat, ezeket gyakran interjúk színesítik. A kiadványok mindegyikében fellelhető a dokumentum végén található Magyarázatok című fejezet, ahol a szövegben szereplő nehezen érthető szavak, kifejezések magyarázatát olvashatjuk. A szövegek könnyen érthetőségét minden oldaIon magyarázó képekkel támogatják.

\section{Európa Nekünk - Most mi is szavazunk!}

A dokumentum a 2019-ben elsőként kiadott „Európa Nekünk” hírlevél. A „Most mi is szavazunk!" alcímet viseli, amely utal a kiadvány fő témájára, a 2019-es európai parlamenti választásra, az értelmi sérült személyek szavazati jogára és a választáshoz való hozzáférésre (Inclusion Europe, 2019a).

\section{Európa Nekünk - Europe in Action konferencia Litvániában}

A kiadvány az „Európa Nekünk” 2019-ben kiadott második száma. A fő témái a Litvániában megtartott „Europe in Action” konferencia, a 2019-es európai parlamenti választások, illetve a European Platform of Self Advocacyben (EPSA, Önérvényesítők Európai Platformja) történő elnökválasztás (Inclusion Europe, 2019b). 


\section{Európa Nekünk - Különszám a Halljátok a hangunkat címü konferenciára: Számít a hangunk!}

Ez a különszám a kiadvány megjelenését követően megtartott „Halljátok a hangunkat" című konferencia alkalmából készült. Annak okán, hogy ezt az eseményt önérvényesítők számára rendezték, a hírlevél ezen különszáma önérvényesítőkkel készített interjúkat tartalmaz; érintve az élettörténeteiket, a saját életük adta lehetöségeiket és korlátaikat (Inclusion Europe, 2019c).

\section{Európa Nekünk - Akkor lesz inklúzió, ha kiállunk magunkért!}

A kiadvány fő témája az EPSA által szervezett „Halljátok a hangunkat” című konferencia, emellett tájékoztatást nyújt a biztonságos internethasználatról és a fogyatékos gyermekek intézményi kitagolásáról is. Két interjút is tartalmaz, amelyek értelmi sérült személyek életéröl és munkájáról szólnak (Inclusion Europe, 2019d).

\section{Alkalmazott módszerek}

Az általam vizsgált témában korábban nem történt kutatás. Ezért ez a vizsgálat egyszerre elméleti és gyakorlati jellegű kutatómunka. Reményeim szerint általa betekintést nyerhetünk a szabályrendszerekben található szabályok betartásának világába. A kutatás eredményei alapján lehetőségünk nyílik mérlegelni a vizsgált szabály észszerüségét. Felmerülhet a szabályok módosításának, pontosításának vagy kiegészítésének igénye.

Szisztematikusan kiválogattam a szabályok közül a mondatalkotásra vonatkozó szabályokat. Ezek mindegyikének az érvényesülését ellenőrzöm a vizsgált négy kiadványban:

1. Az új mondat új sorban kezdődik.

2. A mondat egy gondolatból áll.

3. A mondatot egy sorban írták.

4. A mondat pozitív tartalommal bír.

5. A mondat kerüli a szavak elválasztását.

A fentieket két olyan szemponttal egészítettem ki, amelyek nincsenek benne a szabályrendszerekben:

1. Rövid mondatokat alkottak.

2. Ha a mondatot két vagy több sorban írták, akkor ott szakították-e meg, ahol olvasási szünetet lehet tartani.

Vizsgálatukat mégis szükségesnek ítéltem meg. Ennek indoklását „A vizsgálat eredményei" fejezetben fejtem ki.

Minden kiadványból a bevezető résztől a befejező, Magyarázatok címü fejezet végéig az összes mondatot listáztam először egy Word-dokumentumban, majd az eredmények számszerűsíthetősége érdekében áttettem a listát egy Excel-táblázatba. Minden mondatot egyenként vizsgáltam az összes itt felsorolt szempont szerint. 


\section{A VIZSGÁLAT EREDMÉNYEI}

\section{A szabályok érvényesülésének bemutatása, értékelése és elemzése}

Az alábbi fejezetben - sorra véve a mondatokra vonatkozó szabályokat - bemutatom, hogy a mintában szereplő kiadványokban hány mondatot találtam, hány mondat nem követte a szabályt, illetve hány mondat kompenzálta a szabály megszegését más szabály követésével.

\section{Az új mondat új sorban kezdődik?}

A négy megvizsgált kiadvány bevezető részétől a befejező Magyarázatok című fejezet végéig tartó tartománya összesen $1317 \mathrm{db}$ mondatot tartalmaz. Ebböl $1315 \mathrm{db}$ mondat új sorban kezdődik, és csak 2 nem. A két nem új sorban kezdődő mondatra jellemző, hogy pár szóból állnak és rövidek. Elképzelhető, hogy ezek a mondatok a rövidségük miatt kevésbé észlelhetők különálló mondatként a szövegben, feltehetöleg ezért történt a sorváltás elmulasztása. Nem találtam egyéb olyan tényezőt, amely által ezek a szabálytalanságok indokolttá válhatnának.

\section{Rövid-e a mondat?}

Az útmutató egy fontos szabálya az, hogy rövid mondatokat használjunk. Ezúttal felmerül a kérdés, hogy mely mondatokat tekinthetjük rövidnek. A szabályrendszer ehhez igyekszik segítséget nyújtani azzal a meghatározással, hogy ha a mondat egy gondolatot tartalmaz, akkor rövid lesz. Azonban azt gondolom, hogy a gondolatok száma mellett más tényező is befolyásolhatja a mondatok hosszát, például a szavak hossza vagy egyes felsorolások, hiszen hosszú szavak vagy terjedelmes felsorolások az egy gondolatból álló mondatokban is előfordulhatnak. Ebből kiindulva szükségesnek tartottam külön vizsgálni azt, hogy a mondatok egy gondolatból állnak-e, illetve, hogy a mondatok a szubjektív megítélésem szerint rövidek-e. Ez utóbbi minősítések, besorolások a mondat terjedelmére vonatkoznak. A terjedelmet illetően nem határoztam meg szószámokra vagy karakterszámokra vonatkozó intervallumot, hanem a mondat egy lendülettel való elolvasása volt az irányadó. Lendület alatt ebben a tanulmányban a kutató lendületét, olvasási sebességét értem. Nyilvánvaló, hogy ez nem egy objektív kategória, hiszen a lendület az olvasó számos képességétől függ. A négy kiadványban található mondatok közül 1041 db mondatról állapítottam meg, hogy a terjedelme rövid, amely 79 százalékot jelent. A rövid mondatok aránya tehát magas, viszont a 21 százalékot jelentő 276 db hosszúnak ítélt mondat lényegesen több, mint az egynél több gondolatot tartalmazó mondatok száma. Ebből arra következtethetünk, hogy a mondatok nem minden esetben válnak röviddé kizárólag azáltal, hogy csak egy gondolatot fogalmazunk meg bennük. Ez esetben is elöfordulhatnak olyan, a mondatalkotásra vonatkozó szabályoktól eltérő megoldások, amelyre igazán nem találunk indokot, viszont a mondatok hosszúságára hatást gyakorló körülmények magyarázatot adhatnak az eltérésekre. Ennek összefüggéseit szintén 
„Az eredmények bemutatása, elemzése és értelmezése a szabályok együttes érvényesülésére fókuszálva" című fejezetben fejtem ki.

\section{Egy mondat egy gondolatból áll?}

A mondatok vizsgálata során felmerült a kérdés, hogy mi számít egy gondolatnak, ugyanis az útmutatóból nem tudhatunk meg erre vonatkozó információt. A gondolat a „nagy egészből” egy egység, a gondolatmenet építőköve, amely tovább nem bontható (Keszler \& Lengyel, 2019). Így az elemzés során a mondatot az esetben ítéltem egy gondolatot tartalmazó mondatnak, ha nem volt tovább bontható olyan önálló tartalmi egységekre, amelyek önálló mondatot, illetve tagmondatot tudnának képezni. Ez alapján a négy kiadvány 1317 db mondata közül 1150 db mondat egy gondolatból áll, amely 87,3 százalékot jelent. Ez az igen magas érték rámutat a szabály követhetőségére, azonban mindenképpen figyelembe kell venni a 12,7 százalékot kitevő $167 \mathrm{db}$ mondatot. Megfigyelésem szerint a szabályt megszegő mondatok esetében elkerülhető lett volna a gondolatok halmozása azáltal, hogy mielőtt új gondolatba kezdünk, a mondatot lezárjuk, és új mondatban folytatjuk a következő gondolatot. Ez az irányadó meghatározás a szabályrendszerben szerepel is. Mindemellett azt gondolom, hogy az esetek egy részében sejthető, hogy milyen körülmény vezethetett a szabályszegéshez. Erre a lehetséges befolyásoló tényezőre „Az eredmények bemutatása, elemzése és értelmezése a szabályok együttes érvényesülésére fókuszálva" című fejezetben fogok kitérni.

\section{Hány sorból állnak a mondatok?}

Az 1315 db mondat közül 582 db mondat egysoros, 735 db viszont egynél több sort tesz ki. Főszabályként az útmutató az egy mondat - egy sor elvet vallja, de ettől eltérést enged adott esetben; ilyenkor azonban fontosnak tartja, hogy ott legyen sortörés, ahol olvasási szünetet lehet tartani . A két sorba írt mondatok közül 394 esetben megfelelő helyen történt a sortörés, 64 esetben pedig nem. A szabályrendszer nem tér ki azonban azokra a mondatokra, amelyek több, mint két sort tesznek ki. Az általam áttekintett négy kiadványban 277 ilyen eset fordult elö. Azt gondolom, hogy a kétsoros mondatokra vonatkozó meghatározás lényege a megfelelö, hangsúlyokat figyelembe vevő tagoltság, ezért a kettőnél több soros mondatoknál ugyanezen szempont szerint végeztem a megfigyelést, külön kigyüjtve ezeket a mondatokat. Ilyen módon az összes több sorba írt mondat közül 234 olyan mondatot találtam, amely több, mint két sorból áll, de megfelelő helyeken törik meg azokat, illetve 43 olyan mondatot számoltam össze, amelyek több, mint két sorból állnak, viszont nem megfelelő helyeken van sortörés. Megállapítható, hogy a négy megvizsgált kiadvány mondatainak 44 százaléka egysoros, míg 56 százaléka egynél több sort képez. Az egy sorba írt mondatok aránya alacsony értéket mutat. Véleményem szerint ezt a szabályt nagyon nehéz betartani. A szabályrendszer megengedő, ugyanis iránymutatást ad arra is, hogy milyen módon lehet helyesen eljárni két sorba írt mondatok esetén. Amennyiben a feltétel megvalósul, vagyis a sort ott szakították meg, ahol szünetet lehet tartani az olvasásban, akkor helyesen jártak el. Emellett a két sort képező mondatok mellett számos olyan mondat is van, amely kettőnél több sorból áll. 
Az összes megvizsgált mondat 21 százalékáról van szó, illetve az egynél több sorból álló mondatok 38 százalékáról. Ez a mennyiség számottevő. Mivel az útmutató nem tiltja a kettőnél több sorból álló mondatok alkalmazását, de nem is határoz meg konkrétan azokra irányuló szabályt, a két sorból álló mondatokhoz hasonlóan tekintettem át azokat. Ebből kifolyólag a továbbiakban e két kategóriát egy kategóriába, a több sorba írt mondatok csoportjába sorolom.

\section{A több sorba írt mondatok esetei}

Most tekintsük át, hogy a több sorba írt mondatok milyen mértékben teljesítik a meghatározott feltételt, hiszen a mondatok sormennyiségeinek szabályosságát ez mutatja meg reálisabb módon. A szóban forgó mondatok az esetek 85,4 százalékában szabályosan szerepelnek a kiadványokban, vagyis a sorokat megfelelő helyen szakították meg. 107 mondat viszont helytelen módon szakítja meg a sort, illetve sorokat. Ez az érték 14,6 százalékot jelent, amely összességében nem magas, de ezen szabálytalanságokat magyarázó indokokat nem találtam.

\section{A felsorolások esetei}

Az ellenőrzés során észrevettem, hogy a hosszúnak ítélt, illetve a többsoros mondatok között elöfordulnak pontokkal jelzett felsorolások. A négy kiadványban összesen $56 \mathrm{db}$ felsorolás található. Ezek közül $17 \mathrm{db}$ felsorolásban minden felsorolást jelző pont külön mondatot fejez ki, 39 esetben pedig minden felsorolást jelző pont az egész mondat egy-egy része. A szabályrendszer felhívja a figyelmet, hogy a veszszőkkel elválasztott, egymás mellé írt felsorolás helyett pontokat használjunk, és a felsorolás tagjait egymás alá írjuk. Az egymás alá strukturálás könnyebben olvasható, mint az egymás mellé való felsorakoztatás. Ugyanakkor az egymás alá írás megnyújtja a szöveget, és többsorossá teszi az adott mondatot. Vannak tehát olyan helyzetek, amikor nem lehet két szabályt egyszerre érvényesíteni, és választani kell közülük. Ilyenkor azt a szabályt célszerű választani, amelyik a könnyen olvashatóságot és könnyen érthetőséget jobban szolgálja. A vizsgált hírlevelek elemzésének a tapasztalatai alapján úgy vélem, hogy könnyebben olvasható az a szöveg, amelyikben a felsorolás tagjait annak ellenére egymás alá rendezzük, hogy a mondat látszólag ettől hosszabbá válik.

\section{A mondatok pozitív tartalommal bírnak?}

Az 1317 db mondat közül 1237, vagyis az összes mondat 94 százaléka pozitív tartalommal bír. $A z$ is látható, hogy a mondatok 6 százalékának (80 eset) negatív tartalma van. A szabály követése szempontjából ez egy kedvező arány, és ha figyelembe vesszük a szabálytól eltérő esetek indokoltságának arányát, az eredmény még kedvezőbbé válik. Ugyanis a 80 negatív tartalmú mondat közül 60 mondat, vagyis az esetek 75 százaléka azért rendelkezik negatív tartalommal, mert vagy egy előző mondatban megfogalmazott kérdésre adott nemleges válaszról van szó, vagy olyan igék és melléknevek tagadásáról, valamint tagadó- és fosztóképzőt tartalmazó szóról van szó, amelyek más szóval, kifejezéssel leírva bonyolultabbá válhatnak. Tehát 
a negatív tartalmú mondatok háromnegyedében indokoltnak tartom a szabálytól való eltérést. 20 mondatban viszont elkerülhetö lett volna a tartalom negatív módon való kifejezése. Például a „Tudom, hogy ez sokszor nem könnyü.” (Inclusion Europe, 2019d:14) mondatban a „nem könnyü” helyett a „nehéz” szó használata elkerülte volna a tagadást, és nem vált volna bonyolultabbá. Azonban egyes helyzetekben sejthető, hogy miért választották mégis a negatív tartalmat: a kontextus miatti árnyaltság okán. Az elöbb felhozott példamondat az értelmi sérült személyek nehezített munkavállalásának témakörében található. Ezért feltételezhetően a többségi társadalom tagjainak „könnyebb” munkavállalásával kívánták szembeállítani az értelmi sérült emberek e téren megjelenő nehézségét - a „nem könnyü” kifejezéssel. Összességében megállapítható, hogy a megvizsgált kiadványokban nem okoz jelentős problémát a negatív tartalom elkerülése.

\section{A mondatok kerülik a szóelválasztást?}

A négy megvizsgált kiadvány mondatainak szinte mindegyike kerüli a szóelválasztást, csupán egy esetben történt ilyen szabálytalanság. Ebben az egy mondatban a sor végére esett egy idegen szó, amelynek a toldalékolása kötőjel használatával történt. Ez önmagában nem indokolja az elválasztást, de elképzelhetö, hogy egy nem idegen szó esetében, ahol a kötőjel nem szükséges a toldalékoláshoz, az elválasztás gondolata kisebb eséllyel merül fel. Összességében az látható, hogy az elválasztás elkerülésére felhívó szabály könnyen betartható.

\section{Az eredmények bemutatása, elemzése és értelmezése a szabályok együttes érvényesülésére fókuszálva}

Összesítve, hogy a kiadványokban vizsgált mondatokban hány szabályt sikerült következetesen érvényesíteni, láthatjuk, hogy a szabályoktól inkább eltérő mondatok kisebb arányúak, inkább a szabályoknak megfelelő mondatok a jellemzők. Ugyan a helyesen megszakított, több sorból álló mondatok más kategóriába tartoznak, mint az egysoros mondatok, a számítás során mégis egy csoportba, a szabályt követő mondatok csoportjába tartozónak vettem őket, hogy az összesítésben megőrizzem a szabálytalanul megszakított mondatok arányát. A mondatok nagy részében a különböző szabályok követése jól tud érvényesülni egymás mellett. Sok olyan mondat van, amelyben akár kettőnél is több szabály érvényesül, és nincs olyan mondat, amelyben egyik szabályt sem tartották be.

Mint korábban említettem, egy-egy szabály megszegése esetében fontos áttekinteni, hogy van-e indok a szabálytól való eltérésre. Azt gondolom, ennek feltárását szolgálja az, ha a mondatokra vonatkozó szabályok együttes előfordulását, valamint azok egymásra való hatását figyeljük meg.

A továbbiakban a következő meghatározások együttes előfordulásának eseteit fejtem ki:

1. A mondat egy gondolatból áll.

2. A mondat rövid - szubjektív megítélés szerint. 
3. A mondat egysoros.

4. Ha a mondat két vagy több soros, akkor ott szakították meg, ahol szünetet lehet tartani az olvasásban.

\section{A szabályok érvényesülése az egy gondolatból álló mondatokban}

Az egy gondolatból álló mondatok több mint fele rövid és egysoros. 31 százaléka pedig szintén rövid, de több sorból áll, amelyeket megfelelően szakítottak meg. Azt is láthatjuk, hogy nagyon kevés olyan egy gondolatból álló mondat van, amelyek egy sort alkotnak, de hosszúak, vagy a sorokat szabálytalanul megszakítva több sort alkotnak és hosszúak. Tehát az egy gondolatot tartalmazó mondatokhoz szorosan kapcsolódik a rövid terjedelem, illetve az egy-vagy többsoros, de szabályosan megszakított szerkesztés. Az esetek összesen 12,6 százalékában, amikor az egy gondolatból álló mondat hosszú, akkor többnyire több sorból áll a mondat.

\section{A szabályok érvényesülése a több gondolatból álló mondatokban}

A több gondolatból álló mondatok 68,3 százaléka hosszú és többsoros, de megfelelö helyen megszakított mondat. Csupán 21,6 százaléka rövid, és azon belül is 2,4 százaléka egy sorban íródott rövid mondat. Az, hogy a mondatok több gondolatból állnak, leginkább a mondatok hosszára és sorainak számára van hatással, vagyis sok esetben hosszabbá és több sorból állóvá válik töle a mondat. Az arányok azt mutatják, hogy a sorok megfelelö helyen való megszakítása nincs szoros összefüggésben azzal, hogy a mondat több gondolatból áll.

\section{A szabályok érvényesülése a szubjektív megítélésem szerinti rövid és hosszú mondatokban}

Azoknak a mondatoknak, melyeknek terjedelmét rövidnek ítéltem meg, 55,4 százaléka egy gondolatból áll és egy sort tesz ki. Szintén nagy részük, 34 százalékuk egy gondolatból áll, és többsoros, de a sorokat megfelelő helyen szakították meg. A rövid mondatok elenyésző része, összesen 3 százaléka tartalmaz több gondolatot. Tehát a kiadványok azon mondatait találtam leginkább rövid terjedelműnek, amelyek egy gondolatból állnak, és emellett vagy egy sort képeznek, vagy pedig többet, de azokat ott szakították meg, ahol az olvasásban szünetet lehet tartani. A kiadványok mondatainak 41,5 százaléka akkor is rövid, ha több sorból áll.

A hosszú terjedelmű mondatok összesen 52,6 százaléka egy gondolatból áll. Ebböl arra következtethetünk, hogy a mondatok egy gondolatban való megfogalmazása nem feltétlen eredményez rövid mondatot. Azonban az esetek nagy részében, 85,5 százalékában a mondatok hosszúak, amikor azok többsorosak és megfelelő helyen szakították meg a sorokat. A hosszú mondatok szinte mindegyike, 99,6 százaléka több sorból áll; ugyanakkor a több sorból álló mondatok nem feltétlenül hosszúak. 


\section{A szabályok érvényesülése a több sorba írt, megfe- lelöen megszakitott mondatokban, valamint a több sorba írt, szabálytalanul megszakitott mondatokban}

A többsoros mondatoknak, függetlenül attól, hogy a soraikat megfelelő helyen szakították-e meg, több mint 60 százaléka rövid. Emellett a többsoros mondatok több mint háromnegyed része csak egy gondolatot tartalmaz, ebből 75 százalék pedig rövid is. Ebböl az látható, hogy a többsoros mondatok sok esetben röviddé válhatnak, ha csak egy gondolatot tartalmaznak. A szabályosan és szabálytalanul megszakított többsoros mondatok viszonya a többi szabállyal nagyon hasonló. Kisebb különbség, hogy míg a több sorba írt, megfelelöen megszakított sorú mondatok között van olyan, ami több gondolatból áll, mégis rövid, a szabálytalanul megszakított sorú mondatok esetén nem fordul ilyen elö. Ez a különbség azonban nem számottevő.

\section{A mondatok esetei együttesen megfigyelt szabályok alapján}

A megvizsgált kiadványok összes mondatának 71,1 százaléka tartja be valamilyen módon a jelenleg szóban forgó szabályok mindegyikét. Ebböl a legtöbb rövid, egy gondolatból áll, és egysoros, de sok olyan mondat is van, amely rövid, egy gondolatból áll, és ugyan többsoros, de azok megfelelő megszakítást kaptak.

A mondatok 2,4 százaléka több gondolatból tevődik össze, és megfelelő megszakítással többsoros. Ennek ellenére mégis rövid maradt a terjedelmük. Ez összesen 32 esetet jelent, amely az összes mondattal összevetve nem sok, de a több gondolatból álló mondatok 19 százaléka, vagyis közel egyötöde. Korábban kifejtettem, hogy az útmutató leírása szerint a mondat rövid lesz akkor, ha egy mondatba csak egy gondolatot írunk. Viszont az előbb említett eseteket figyelembe véve fennáll az a lehetőség, hogy azért fordultak elő több gondolatból álló és több sort kitevő mondatok, mert azok rövid terjedelmüek tudtak maradni.

A kiadványok összes mondatának 76,3 százaléka egy gondolatból álló rövid mondat. E kategóriának pedig 57 százaléka, vagyis több, mint a fele több sorból áll. Ez azt jelenti, hogy a mondat akkor is lehet rövid, ha egy gondolatból áll, de többsoros. Viszont az ilyen esetek 16 százalékát nem ott szakították meg, ahol szünetet lehet tartani az olvasásban, ez pedig akadályozza a könnyen érthetőséget. Ezek az eredmények arra engednek következtetni, hogy hiába valósulhat meg az, hogy az egy gondolatból, de több sorból álló mondatok rövidek maradhatnak, ha ezeknek egy része mégsem könnyen érthető, mert soraikat nem megfelelö helyen szakították meg.

A megvizsgált mondatok összesen 11 százaléka egy gondolatból áll, ezzel együtt hosszú és többsoros. Ezekben az esetekben a mondatok hosszúságát okozhatja az, hogy több sorban nyúlnak el, viszont elképzelhető, hogy azért fordultak elő ilyen mondatok, mert csak egy gondolatot tartalmaznak. Az útmutató pedig azt mondja, hogy rövid lesz a mondatunk, ha az egy gondolatot tartalmaz. Viszont ez a megvizsgált négy kiadvány azt mutatja, hogy nem feltétlen válnak röviddé az egy gondolatot 
tartalmazó mondatok. Az elemzésem szerint ennek oka vagy az emberi tévesztés lehet, vagy pedig az, hogy egy hosszú, több sorba íródott mondat is tartalmazhat csupán egy gondolatot.

\begin{tabular}{|c|c|c|}
\hline A MEGFIGYELT SZABÁLYOK & $\begin{array}{l}\text { SZABÁLYKÖVETŐ } \\
\text { MONDATOK }\end{array}$ & $\begin{array}{l}\text { SZABÁLYTÓL ELTÉRŐ } \\
\text { MONDATOK }\end{array}$ \\
\hline $\begin{array}{l}\text { Az új mondat új sorban } \\
\text { kezdődik. }\end{array}$ & $\begin{array}{l}\text { Sylvie Guillaume az Európai } \\
\text { Parlament alelnöke. }\end{array}$ & $\begin{array}{l}\text { Ez jó munkahely! Már hét éve } \\
\text { itt dolgozom. }\end{array}$ \\
\hline A mondat egy gondolatból áll. & $\begin{array}{l}\text { A konferencia a befogadásról } \\
\text { szólt. }\end{array}$ & $\begin{array}{l}\text { Odamegyek, ahová akarok, } \\
\text { azt csinálok, amit akarok, és } \\
\text { senki nem szól bele. }\end{array}$ \\
\hline A mondatot egy sorban írták. & $\begin{array}{l}\text { De sokan vannak, akik nagyon } \\
\text { nehezen találnak munkát. }\end{array}$ & $\begin{array}{l}\text { A 10. oldaltól a 15. oldalig } \\
\text { értelmi fogyatékossággal } \\
\text { élő szülőkkel olvashattok } \\
\text { interjúkat. }\end{array}$ \\
\hline $\begin{array}{l}\text { A mondat pozitív } \\
\text { tartalommal bír. }\end{array}$ & $\begin{array}{l}\text { A Lebenshilfe egy német szó, } \\
\text { azt jelenti, hogy önsegély. }\end{array}$ & $\begin{array}{l}\text { Nem igazságos, hogy az } \\
\text { értelmi fogyatékossággal élők } \\
\text { nem tudnak szavazni. }\end{array}$ \\
\hline $\begin{array}{l}\text { A mondat kerüli a szavak } \\
\text { elválasztását. }\end{array}$ & $\begin{array}{l}\text { A Lászlóval készült interjút az } \\
24 \text {. oldalon találod. }\end{array}$ & $\begin{array}{l}\text { Új tagszervezetek is } \\
\text { csatlakoztak az Inclusion } \\
\text { Europe-hoz. }\end{array}$ \\
\hline A mondat rövid. & $\begin{array}{l}\text { Sokat vagyok Brüsszelben és } \\
\text { Strasbourgban. }\end{array}$ & $\begin{array}{l}\text { Mit lehet tenni azért, hogy } \\
\text { a komplex támogatási igényű } \\
\text { emberek is akadálymentesen } \\
\text { részt tudjanak venni } \\
\text { a találkozókon? }\end{array}$ \\
\hline $\begin{array}{l}\text { Ha a mondatot két vagy } \\
\text { több sorban írták, akkor ott } \\
\text { szakították meg, ahol olvasási } \\
\text { szünetet lehet tartani. }\end{array}$ & $\begin{array}{l}\text { Egy másik önérvényesítő azt } \\
\text { mondta, hogy nagyon szeretne } \\
\text { szavazni, mert a szavazata } \\
\text { változást hozhatna az értelmi } \\
\text { fogyatékossággal élőknek. }\end{array}$ & $\begin{array}{l}\text { A komplex támogatási igény } \\
\text { azt jelenti, hogy valakinek több } \\
\text { dologban is támogatásra van } \\
\text { szüksége. }\end{array}$ \\
\hline
\end{tabular}




\section{A MONDATOK ESETEI EGYÜTTESEN MEGFIGYELT SZABÁLYOK ALAPJÁN}

- Egy gondolatból áll,

- rövid,

- egy mondat egy sorban van leírva.

- Egy gondolatból áll,

- rövid,

- egy mondat több sorban van leírva, megfelelően megszakítva.

- Egy gondolatból áll,

- rövid,

- egy mondat több sorban van leírva, szabálytalanul megszakítva.

- Egy gondolatból áll,

- hosszú,

- egy mondat egy sorban van leírva.

- Egy gondolatból áll,

- hosszú,

- egy mondat több sorban van leírva, megfelelően megszakítva.

- Egy gondolatból áll,

- hosszú,

- egy mondat több sorban van leírva, szabálytalanul megszakítva.

- Több gondolatból áll,

- rövid,

- egy mondat egy sorban van leírva.

- Több gondolatból áll,

- rövid,

- egy mondat több sorban van leírva, megfelelően megszakítva.

- Több gondolatból áll,

- rövid

- egy mondat több sorban van leírva, szabálytalanul megszakítva.

- Több gondolatból áll,

- hosszú,

- egy mondat egy sorban van leírva.

- Több gondolatból áll,

- hosszú,

- egy mondat több sorban van leírva, megfelelően megszakítva.

- Több gondolatból áll,

- hosszú,

- egy mondat több sorban van leírva, szabálytalanul megszakítva.

\section{Példamondatok}

A közelmúltban megújult a honlapunk.

És fontos nekünk,

hogy válasszunk!

Mindannyian képesek

vagyunk választani.

A Lebenshilfe harcolt a törvény megváltoztatásáért.

Ebben a kiadványban sok cikket fogsz arról találni:

- Az európai választásokról

- szavazati jogról

- a választásokhoz való hozzáférésröl

Mit mondasz az olyan értelmi fogyatékossággal élő embereknek, hogy menjenek el szavazni?

Az EPSA közgyűlésén választották meg, júniusban.

Az Európai Unió egy csoport, aminek 28 ország a tagja.

$-$

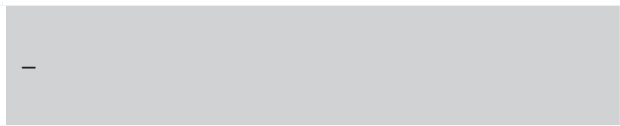

Például, hogy legyenek rámpák,

így kerekesszékkel is fel lehessen menni a színpadra.

Ha azt írod, hogy \#inclusion, és rákattintasz, meglátod

azokat az üzeneteket, amik az Inclusion Europe-hoz kapcsolódnak. 
- Egy gondolatból áll,

- rövid,

- egy mondat egy sorban van leírva.

- Egy gondolatból áll,

- rövid,

- egy mondat több sorban van leírva, megfelelően megszakítva.

- Egy gondolatból áll,

- rövid,

- egy mondat több sorban van leírva, szabálytalanul megszakítva.

- Egy gondolatból áll,

- hosszú,

- egy mondat egy sorban van leírva.

- Egy gondolatból áll,

- hosszú,

- egy mondat több sorban van leírva, megfelelően megszakítva.

- Egy gondolatból áll,

- hosszú,

- egy mondat több sorban van leírva, szabálytalanul megszakítva.

- Több gondolatból áll,

- rövid,

- egy mondat egy sorban van leírva.

- Több gondolatból áll,

- rövid,

- egy mondat több sorban van leírva, megfelelően megszakítva.

- Több gondolatból áll,

- rövid,

- egy mondat több sorban van leírva, szabálytalanul megszakítva.

- Több gondolatból áll,

- hosszú,

- egy mondat egy sorban van leírva.

- Több gondolatból áll,

- hosszú,

- egy mondat több sorban van leírva, megfelelően megszakítva.

- Több gondolatból áll,

- hosszú,

- egy mondat több sorban van leírva, szabálytalanul megszakítva.

Összes mondat száma: 1317

A mondatok esetszámai több szabály együttes megvalósulása esetén 


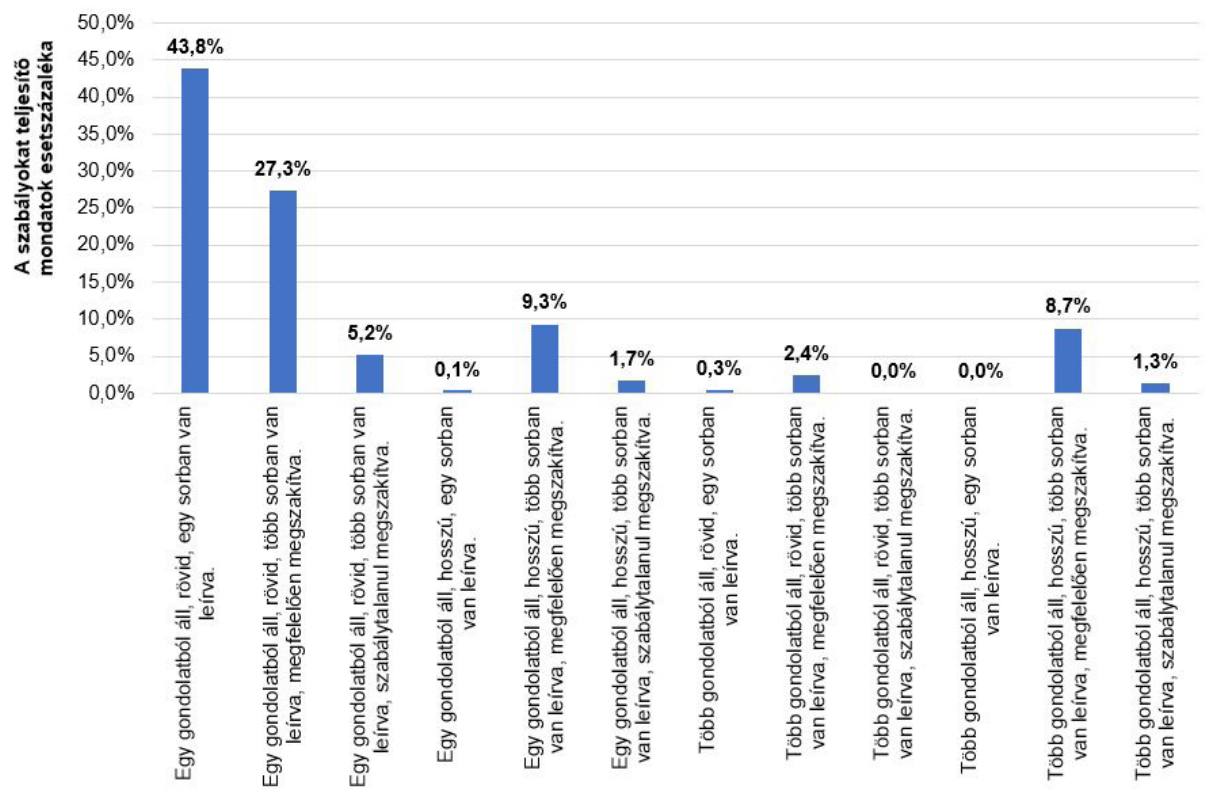

1. diagram: A mondatok eloszlása a szabályok együttes teljesítése alapján

\section{A kutatási kérdések megvitatása}

Az első kutatási kérdésem az volt, hogy a vizsgált dokumentumban az alkalmazott szabályrendszerben rögzített, mondatokra vonatkozó szabályoknak megfelelöen történik-e a mondatok alkotása. Összességében elmondható, hogy a mondatok nagyobb arányban betartják a szabályokat, mint hogy nem követik azokat. Ezek alól kivételt képez az egy sorba írt mondatok esete, ugyanis a több sorba írt mondatok inkább jellemzőek, mint az egy sorba írt mondatok. Ezt viszont igyekszik kompenzálni az az eredmény, hogy több olyan többsoros mondat van, amelynek sorait helyesen szakították meg, mint amelynek szabálytalanul. Megfigyelve a szabályok együttes érvényesülését, azt láthatjuk, hogy a mondatok nagy részében alkalmaztak helyesen egyszerre több szabályt. Az eltérések aránya ugyan nem túl magas, de az elöfordulásuk figyelemre méltó.

A második kutatási kérdésem az volt, hogy amennyiben a vizsgált dokumentumban az alkalmazott szabályrendszerben rögzített, mondatokra vonatkozó szabályoktól való eltérés tapasztalható, akkor az eltérésben felfedezhetö-e hasonlóság, illetve következetesség. A vizsgálat során háromféle hasonlóságot találtam bizonyos szabályoktól való eltérések során. Ezek a hasonlóságok jellemzően jelen vannak, de nem minden esetben fordulnak elö. Az eredmények azt mutatják, hogy a nem egy gondolatból álló mondatok többségére jellemző, hogy hosszú, többsoros mondatokat eredményeznek, melyeknek sorait ott szakították meg, ahol az olvasásban szünetet lehet tartani. Amikor a mondatok nem rövid terjedelműek, akkor a legtöbb esetben, függetlenül attól, hogy hány gondolatból állnak, több sort alkotnak, és a soraikat megfelelően szakították meg. A nem egysoros mondatok pedig a legtöbbször egy gondolatból állnak. 
A harmadik kutatási kérdésem az volt, hogy amennyiben a megvizsgált kiadványokban a mondatokra vonatkozó szabályoktól való eltérések történnek, indokoltak-e az eltérések. A többsoros, hosszú mondatok, valamint a negatív tartalommal bíró mondatok egy részében indokolt eltéréseket találtam.

A negyedik kutatási kérdésem az volt, hogy amennyiben a vizsgált dokumentumban a szabályrendszerben rögzített, mondatokra vonatkozó szabályoktól való eltérések történnek, mivel magyarázható az eltérés. Az útmutató szerint a mondatok rövidek lesznek, ha egy gondolatból állnak, viszont, ha a gondolatot csak úgy lehet megfogalmazni, hogy az több sort alkosson, akkor a mondat hosszúvá válhat. Tehát ezekben az esetekben az az eltérés oka, hogy a gondolat kifejtése csak terjedelmesen kivitelezhető. Emellett a felsorolást jelző pontokkal történő felsorolások is többsoros mondatokat eredményezhetnek, amennyiben minden felsorolást jelző pont az egész mondat egy-egy része. Viszont azok használata az útmutató szerint indokolt a könnyen érthetőség elérése érdekében. A negatív tartalommal bíró mondatok használata indokolt azokban az esetekben, amikor nemleges választ tartalmaz egy előző mondatban megfogalmazott kérdésre, illetve, ha olyan igék és melléknevek tagadásáról, valamint tagadó- és fosztóképzőt tartalmazó szóról van szó, amelyek bonyolultabbá válnának más szóval, kifejezéssel leírva.

Az ötödik kutatási kérdésem az volt, hogy milyen jellegzetességeket lehet megfigyelni a vizsgált dokumentumban megfogalmazott mondatok esetében. Az elemzés során azt találtam, hogy a kiadványok mondatainak szinte mindegyikére jellemző az új sorban történő kezdés, valamint az elválasztások kerülése.

\section{JAVASLATTÉTEL, TOVÁBBI KUTATÁSI LEHETŐSÉGEK}

Az általam vizsgált kiadványokban a szerzők tehát összességében törekedtek a mondatokra vonatkozó szabályok betartására, azonban a feltárt eltéréseket is fontos figyelembe venni. Bár a szabályrendszerek igyekeznek objektív keretet adni, mind a könnyen érthető információforrások készítésekor, mind a szabályok megvalósulásának ellenörzése során elkerülhetetlen a szubjektivitás megjelenése. Ezért úgy gondolom, hogy szükség van a szabályok megfogalmazásának pontosítására, hiszen egyes kifejezések, mint például a „rövid mondat” vagy az „egy gondolat”, szubjektíven értelmezhetőek, ez pedig akadályozhatja más szabályok betartását, ezzel együtt a könnyen érthetőséget. Léteznek olyan mondattípusok is, amelyek alkotására vonatkozó szabályt nem találunk. Meglátásom szerint érdemes lenne a szabályrendszerben olyan esetek pontosítására kitérni, amelyek során két szabály nem tud egyszerre érvényesülni.

A kutatómunkám alapján a mondatokra vonatkozó szabályok megújításához a következö javaslatokat sorakoztatom fel:

1. A szabályrendszerben a mondatok rövidségét jelenleg egy megvalósulandó feltétellel határozzák meg: egy mondatban egy gondolat legyen. A javaslatom a mondat rövidségének konkrétabb meghatározása, mérhetöbb keretek közé szorítása. Az egy mondatban megjeleníthető szavak vagy a karakterszámok felső határának megadása objektívebb, ezáltal követhetőbb feltételt kínálna. 
2. Az a meghatározás, miszerint egy mondatban egy gondolatot kell megfogalmazni, pontosítást, kiegészítést igényel. Javaslom az egy gondolatot és a több gondolatot tartalmazó mondatok legjellemzőbb példáinak felsorakoztatását.

3. A mondatok többsorosságát gyakran a pontjellel történő felsorolás eredményezi - amennyiben a felsorolást jelző pontok az egész mondat egy-egy részei. Ennek egy megoldása lehetne a pontjelzéses felsorolás e típusának tiltása. Azok az esetek továbbra is megengedettek lehetnek, amelyeknél a felsorolást jelző pontok külön mondatokat tartalmaznak.

4. Jelenleg a többsoros mondatok korlátozása és a pontjeles felsorolások engedélyezése is szerepel a szabályrendszerben, de e két meghatározás egymásra való hatása nem. Javaslom a mondatokra vonatkozó szabályok között, a többsoros mondatok esetében a pontjeles felsorolások okozta többsoros mondatok megengedését jelezni. Például: a mondat több sorból állhat, ha pontjeles felsorolást használunk. Ez a módosítás a 3. javaslatom mellett nem állja meg a helyét, a két javaslat külön-külön, „vagy-vagy” választással értelmezendő.

5. A szabályrendszer nem tiltja a kettőnél több soros mondatok használatát, de nem is tér ki arra, hogy hogyan kell azokat helyesen kivitelezni. Javaslom az egy mondatban maximum megengedett sorok számának jelzését, illetve, ha kettőnél több sor megengedett, akkor az azokra vonatkozó helyes kivitelezés meghatározását is.

A kutatásomban nem vizsgáltam a könnyen érthető mondatalkotás minden aspektusát. A szabályok további pontosításához hasznos lenne további kutatásokat végezni, amelyek a szabályrendszer finomítására vonatkozó pontosabb információkkal szolgálnak, valamint olyan gyakorlati kutatásokat is, amelyek a szabályrendszer átformált verziójának eredményességét helyezik a középpontba.

\section{Irodalom}

a Fogyatékossággal élő személyek jogairól szóló ENSZ egyezmény, 2006

Csató Zs. (szerk.) (2002). Egyszerủen, érthetően: útmutató könnyen érthető tájékoztatók készítéséhez. ÉFOÉSZ, Budapest.

Gruiz K. (évszám nélkül). Hogyan készítsünk könnyen érthető segédanyagot? - Irányelvek. Down Alapítvány, Budapest.

Horváth P. L. (2019b). A könnyen érthető kommunikáció meghatározása. Carissimi, X.2:8-10.

Horváth P. L. (2020). A könnyen érthető kommunikációs képzési programok képzésfejlesztésének története Magyarországon a fogyatékossággal élő személyek jogairól szóló ENSZ egyezmény tükrében. (Doktori értekezés.) Eszterházy Károly Egyetem Neveléstudományi Doktori Iskola, Eger.

Inclusion Europe \& ÉFOÉSZ (2009). Információt mindenkinek! A könnyen érthető kommunikáció európai alapelvei. Inclusion Europe - ÉFOÉSZ, Brüsszel - Budapest.

Inclusion Europe (2019a). Európa Nekünk - Most mi is szavazunk! Inclusion Europe, Brüsszel.

Inclusion Europe (2019b). Európa Nekünk - Europe in Action konferencia Litvániában. Inclusion Europe, Brüsszel.

Inclusion Europe (2019c). Európa Nekünk - Különszám a Halljátok a hangunkat címü konferenciára: Számít a hangunk! Inclusion Europe, Brüsszel.

Inclusion Europe (2019d). Európa Nekünk - Akkor lesz inklúzió, ha kiállunk magunkért! Inclusion Europe, Brüsszel.

Keszler B. \& Lengyel K. (2019) Kis magyar grammatika. Akadémiai Kiadó, Budapest. https://doi. org/10.1556/9789630599641

Lányiné Engelmayer Á. (2017). Intellektuális képességzavar és pszichés fejlödés. Medicina Könyvkiadó, Budapest. 
Mede P. (2010). Értelmileg akadályozott gyermekek olvasás-írás tanítása. In Radványi K. (szerk.), ¿MÁSKÉ(P)P? Intellektuális fogyatékossággal élő emberek gyógypedagógusainak tankönyve. ELTE Bárczi Gusztáv Gyógypedagógiai Kar, Budapest. 63-75.

Szabó B. (2006). Inkluzív nevelés. Ajánlások értelmileg akadályozott gyermekek, tanulók kompetencia alapú fejlesztéséhez. Szövegértés-szövegalkotás. suliNova Közoktatás-fejlesztési és Pedagógus-továbbképzési Kht., Budapest.

A szegedi Könnyen Érthetö Információs Központban - többek között - könnyen érthető kiadványokat készítünk, melyeket az alábbi logóval jelöljük meg:

Készítünk majd csak képeket, képeket és szöveget, illetve csak szöveget tartalmazó kiadványokat:

A kiadványok érthetőségét tapasztalati szakértők ellenőrzik.

Az ellenőrzés tényét az alábbi logóval jelöljük:

A kiadványokat a könnyen érthető információ készítésének szabályrendszere alapján dolgozzuk ki. A szabályrendszernek való megfelelés tényét az alábbi logóval jelöljük:
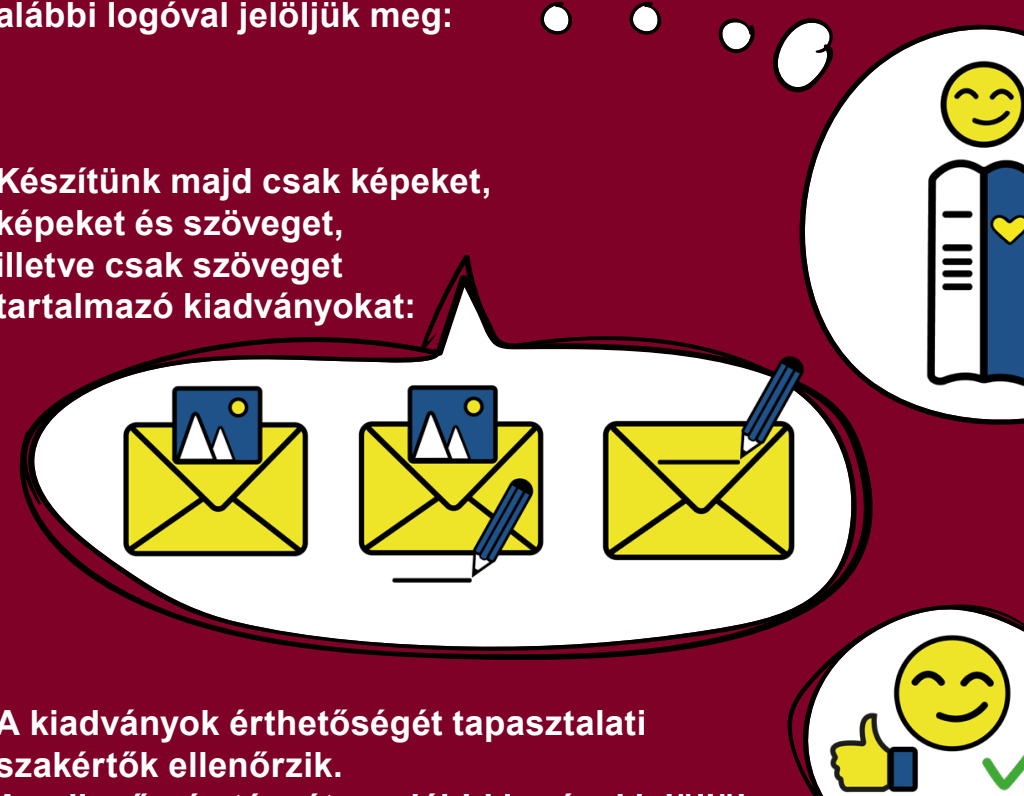

Megjegyzés: a könnyen érthetö üzenet készitésére a magyar

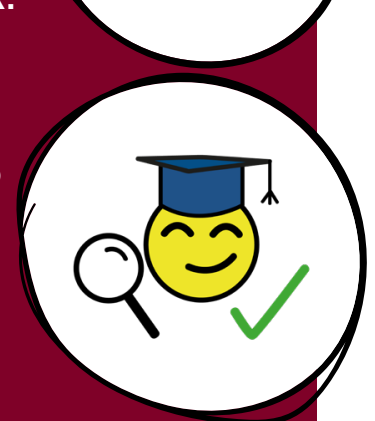
nyelv sajátosságai alapján magyar nyelvü szabályrendszert készítünk. A szabályrendszer várhatóan 2021 decemberében jelenik meg.

\section{A logóhasználat szabályairól tájékozódjon} a projekt honlapján. 


\section{Kutatás a participativitás, az önérvényesítés és a könnyen érthető kommunikáció jegyében}

Jelen tanulmányban egy folyamatban lévő kutatási programot meghatározó négy gondolatkört mutatunk be: önérvényesítés, gondnoksági rendszer kritikája, participatív kutatás, könnyen érthető kommunikáció.

A kutatási program egyik újdonsága és egyben célja az, hogy a kutatási eredményekkel hozzájáruljunk az értelmi sérült személyek önérvényesítő képességének fejlődéséhez. Ezt olyan módon tesszük, hogy őket kérdezzük meg a gondnokság rendszerével kapcsolatban. Másrészt a kutatási programba társkutatóként bevontunk egy olyan személyt, aki maga is egy kisvárosi lakóotthon cselekvőképességet részlegesen korlátozó gondnokság alatt álló lakója. Ezt a fogyatékosságtudományban participatív kutatásnak nevezzük. Maga a kutatás a könnyen érthető kommunikáció módszerének használatával zajlott.

Kulcsszavak: önérvényesités, támogatott döntéshozatal, közvetlen megkérdezés, gondnokság, participativ kutatás, könnyen érthető kommunikáció

Jelen tanulmány „A gondnokságról alkotott vélemény - előny vagy hátrány” című participatív kutatásom alapján készült. A kutatási eredmények első bemutatására 2020-ban került sor a Szegedi Tudományegyetem Juhász Gyula Pedagógusképző Kar Gyógypedagógus-képző Intézet TDK kari fordulóján, ahol 3. helyezést értem el. Az OTDK-n a Pedagógiai, Pszichológiai, Andragógiai és Könyvtártudományi Szekcióban, a Gyógypedagógia elméleti és történeti témakörei II. Tagozatban 2. helyezést értem el. Ebben a cikkben nem a kutatás eredményeit, hanem a kutatás négy fontosabb alappillérét mutatom be. Célom, hogy ezzel egyfajta példát mutassak mindazoknak, akik az értelmi sérült személyekkel közösen az értelmi sérült emberek életének kutatására vállalkoznak.

Ebben a tanulmányban a célcsoport megjelölésére az „értelmi sérült ember” fogalmat használom, ezalatt értem az értelmileg és a tanulásban akadályozott személyeket egyaránt. Az emberi jogi megközelítésből indulok ki. Ezért az értelmi sérülés gyógypedagógiai, illetve orvosi meghatározása a tanulmányban nem releváns.

\section{AZ ÖNÉRVÉNYESÍTÉSRŐL}

Az ENSZ fogyatékossággal élő személyek jogairól szóló egyezménye 3. cikke alapján az értelmi sérült embernek az önérvényesítéshez joga van (fogyatékosságügyi ENSZ egyezmény, 2006). 
Az önérvényesítés mozgalma Edward Roberts nevéhez köthető (Roberts, 2020). Az önérvényesítés angol megfelelője az empowerment. A kifejezés a power (hatalom) szóból ered. Az angol nyelvben a fogalom az eredeti jelentésre utal, ami szó szerint jogi hatalommal való felruházást jelent; engedélyt egy megadott konkrét cél eléréséhez vagy szándék megvalósításához (Rappaport, 1987). „Az empowerment tágabb értelmezésén túl az emancipáció fogalommal operál; a hangsúlyt arra teszi, hogy adott társadalom (közösség) tagjai tudják legjobban, hogy voltaképpen mire is van szükségük" (Budai \& Puli, 2012:7).

Az empowerment egy folyamat, amelyben egyre inkább a kezébe veszi az ember a saját életének irányítását. Tudatosan egyre inkább felelősséget vállal önmagáért. A folyamat belső és külső szegmensekre bontható. A belső folyamat lényege, hogy az ember hisz abban, hogy döntést tud hozni, illetve, hogy meg tudja oldani a problémáit, hogy cselekedni, tenni tud. A külső folyamat pedig abból áll, hogy valóban képes cselekedni, a szerzett tudását a gyakorlatban hasznosítani, új tudást szerezni (Sadan, 2011).

Az önérvényesítés „önismereten alapuló, a saját érdekek felismeréséből következő érdekérvényesítő magatartást jelent, amelynek alapja a kommunikáció" (Horváthné és mtsai, 2011).

A gyógypedagógiában az önérvényesítés azt jelenti, hogy a fogyatékos személyek ki tudnak állni a saját és társaik érdekeiért. Azt is jelenti, hogy megismerik a jogaikat és átadják ezt a tudást a társaiknak is (Bercse \& Czakó, 2019).

Az Önérvényesítők Európai Platformjának európai önérvényesítő szervezetek a tagjai. Rövidítése az EPSA (European Platform of Self Advocates) mozaikszó. Az EPSA az Inclusion Europe szervezet része. Az EPSA 2000 óta képviseli az európai önérvényesítő szervezeteket. Azon dolgozik, hogy erősebbé tegye az európai önérvényesítő mozgalmat: így például 2018 októberében, Brüsszelben az ESPA vezetői képzést tartottak az önérvényesítőknek és családtagjaiknak. A képzés arról szólt, hogy hogyan tudnak beleszólni a politikai életbe európai uniós szinten. A képzés egyik napja az Európai Parlamentben volt, ahol a résztvevők EU parlamenti képviselőkkel tárgyaltak a választójogról. Az EPSA vezetői önérvényesítők. A saját országában mindenki érdekvédelemmel foglalkozik. Jelenleg Bercse László, a magyarországi ÉFOÉSZ társelnöke az EPSA elnöke. A „Halljátok a hangunkat” egy konferencia önérvényesítők számára, amit az EPSA szervez kétévente. A legutóbbi alkalom 2019-ben Grazban, Ausztriában került megrendezésre. Az eseményre 12 országból összesen 150 önérvényesítő és segítő érkezett. A konferencia arról szólt, hogyan tudnak az önérvényesítők részt venni a politikai életben és hallatni a hangjukat úgy, hogy a döntéshozók is meghallják azt. A konferencia során a résztvevők üzeneteket fogalmaztak meg, például: „minden értelmi fogyatékossággal élő embernek legyen választójoga, egész Európában!”; „Aki szavazhat, kapjon könnyen érthető tájékoztatást a választásokról!”; „Szűnjön meg a gondnokság!” (ÉFOÉSZ, 2020).

„A fogyatékos emberek nem jótékonykodás alanyai, hanem jogok birtokosai, önálló akarattal rendelkező autonóm, független személyek. Az állami, kormányzati cselekvéseknek ezért mindenekelőtt azt kell előmozdítaniuk, hogy az intézményrendszer és a társadalom közremüködése ne a fogyatékos emberek helyett történő döntésekre és tevékenységekre irányuljon, hanem arra, hogy a fogyatékos személyek ezeket maguk gyakorolhassák emberi méltóságuk megörzése mellett" (Országos Fogyatékosságügyi Program, 2015). 
Az önérvényesítés jogának a korlátozásaként lehet a cselekvőképesség jogának korlátozását értelmezni. Ha az értelmi sérült személy nem hozhat önállóan döntést, akkor az önérvényesítés sem valósulhat meg. A továbbiakban azt vizsgálom, hogy az önérvényesítés hogyan néz ki a cselekvőképesség tükrében.

\section{A HELYETTES És A TÁMOGATOTT DÖNTÉSHOZATALRÓL}

Jelen tanulmányban a helyettes és támogatott döntéshozatal fogalmának ismertetése azért lényeges, mert utóbbi maga az önérvényesítésnek a támogatása, és amikor participatív kutatótárssal dolgozunk - melyröl részletesebben a következő fejezetben írok -, akkor tulajdonképpen a participatív kutatótárs és én mint kutató éppen ilyen támogatott döntéshozatalt valósítunk meg.

„A helyettes döntéshozatal tulajdonképpen a gondnokság intézményét jelenti, amikor is az adott személyröl azt feltételezik, hogy nem képes megérteni a döntés lehetséges következményeit" (Jakab, 2011:443.).

A támogatott döntéshozatal ezt a helyettes döntéshozatalt hivatott felváltani a magyar jogrendben. Támogatott döntéshozatal esetén a fogyatékos személy által választott bizalmi személy segíti a támogatott személyt a jog előtt is érvényes, az életét érintő kérdések meghozatalában, miközben a támogatott személy cselekvőképességét nem korlátozzák (Ruzsics, 2013).

A cselekvőképesség teljes és részleges korlátozásáról, valamint a helyettes és támogatott döntéshozatalról a témák iránt részletesebben érdeklődő olvasó „A gondnokságról alkotott vélemény - előny vagy hátrány” című TDK-dolgozatomban olvashat (Peszeki, 2021).

A fogyatékos személyek, köztük az értelmi sérült személyek jogait - többek között - a fogyatékosságügyi ENSZ egyezmény határozza meg. Magyarország az elsők között írta alá, majd 2007-ben ratifikálta is, ezáltal az egyezményben leírtak megvalósítását és a megvalósítás ellenőrzését is vállalta (Horváth, 2013).

„A cselekvőképesség minden esetben valamely élő személyhez kötődő, sajátosan humán kompetenciát jelöl: az emberi személy azon képességét, hogy tapasztalatainak és céljainak birtokában, korlátait és lehetőségeit felmérve, az akarás pszichés aktusa révén olyan döntést hozzon, amelynek következményeit felismeri és belátja, rövid és hosszú távú konzekvenciáinak tudatában van, s azért felelősséget vállal. A cselekvőképesség szűkebb kategória az emberi mivolt általános lényegéhez kötött jogképességnél. A jogképesség kategóriája a polgári jogegyenlőség elvének kifejeződése, amely valamennyi élve született, az emberi fajhoz tartozó lényt megillet" (Verdes \& Tóth, 2008:8).

A Polgári Törvénykönyvről szóló 2013. évi V. törvény (Ptk.) a jogi háttere a gondnokság alá helyezésnek. A gondnokság alá helyezés folyamata a döntési képességükben átmenetileg vagy tartósan sérült embereknek a gyámhivatal által kijelölt gondnokon keresztüli segítését szolgálja.

A bíróság cselekvőképességet részlegesen korlátozó gondnokság alá azt a nagykorút helyezi, akinek ügyei viteléhez szükséges belátási képessége - mentális zavara következtében - tartósan vagy időszakonként visszatérően nagymértékben csökkent, és emiatt - egyéni körülményeire, valamint családi és társadalmi kapcsola- 
taira tekintettel - meghatározott ügycsoportban gondnokság alá helyezése indokolt [Ptk. 2:19. § (1)-(2) bek.].

A gondnokság alá helyezésröl orvosi szakvélemény alapján a bíróság hoz határozatot. Ez a határozat nem élethosszig tartó. Mivel az idő múlásával az egyén belátási, valamint mentális képességei változhatnak, így a gondnokság alá helyezést meghatározott időközönként kötelező felülvizsgálni. Ez a felülvizsgálat „a cselekvőképesség részleges korlátozása esetén nem lehet későbbi, mint az ítélet jogerőre emelkedésétől számított öt év; a cselekvőképesség teljes korlátozása esetén nem lehet későbbi, mint az ítélet jogerőre emelkedésétől számított tíz év" [Ptk. 2:29. § (1) bek. a) pont].

A területileg illetékes gyámhivatal a gondnokság alatt álló személy mellé kirendelő határozattal nevez ki gondnokot. A gondnok feladata a gondnokolt képviselete, bevételének, vagyonának kezelése. A gondnoki tevékenységről évente kell beszámolnia, a vagyonkezelést illetően a gondnokság alatt álló vagyoni leltára alapján. A vagyonkezelés az érintett ingó és ingatlan vagyonára, annak kezelésére, bevételeire és kiadásaira vonatkozik. A gondnoki szerepkört minden 18. életévét betöltött, teljes mértékben cselekvőképes személy betöltheti, ha vállalja a tisztséget. Az arra alkalmas személyek közül a szülőket, más hozzátartozókat - akik szükség esetén a személyes gondoskodást is el tudják látni - előnyben kell részesíteni. Nem lehet kirendelni olyan gondnokot, akinek a személye ellen a gondnokolt egyértelmüen tiltakozik. Ha a szülö, hozzátartozó nem alkalmazható, vagy nem vállalja a tisztséget, a gondnokolt számára hivatásos gondnokot kell kirendelni [Ptk. 2:31. § (1)-(3) bek.].

Az a személy válhat hivatásos gondnokká, aki az alábbi feltételeknek eleget tesz: 18. életévét betöltötte, cselekvőképes, büntetlen előéletű magyar állampolgár, akivel szemben a jogszabályokban meghatározott kizáró körülmény nem áll fenn. A hivatásos gondnok személyének további feltétele, hogy legalább középfokú iskolai végzettséggel rendelkezzen, és a rendeletben meghatározott képzést sikeresen elvégezze. A gondnok tevékenységéért díjazásban nem részesül, de az esetlegesen felmerülő költségeinek megtérítését igényelheti. Munkadij csak a hivatásos gondnokot illeti meg [Ptk. 2:31. § (5) bek.].

Számos kutatás, tanulmány született már a gondnokság rendszerével kapcsolatban, azonban ezen munkák közös jellemzője, hogy nem a gondnokság alá helyezett személyeket kérdezték (Gazsi, 2016; Kaló \& Horváth, 2019). Kiemelkedően fontosnak tartom, hogy hangot adjunk maguknak, az értelmi sérült személyeknek is. Éppen ezért kutatásomban a gondnokolt személyeket kérdeztem meg. Ugyanakkor a kutatás megkezdésekor olyan félelem merült fel bennem, hogy a lakóotthonban élő értelmi sérült személyek nem szívesen osztanák meg és részleteznék egy ismeretlen személlyel a történeteiket, élményeiket. Tartottam attól is, hogy nem biztos, hogy át fogom tudni látni a gondnokság bonyolult rendszerét. A harmadik nehézséget a könnyen érthető interjúk elkészítése okozta: ugyanis a lakóotthonban élő értelmi sérült személyek eltérő képességekkel rendelkeznek, így szükséges volt az is, hogy az interjúkérdések könnyen érthető formában is rendelkezésre álljanak. Ezen okoknál fogva, valamint témavezető tanárom javaslatára elgondolkodtam a participatív kutatás lehetőségén. 


\section{PARTICIPATÍV KUTATÁS}

Amikor a sérült személyek önállóan kutatnak, azt emancipatív kutatásnak, amikor viszont ép és sérült személyek közösen kutatnak, azt participatív kutatásnak nevezik. Participatív kutatás esetében már maga a kutatási folyamat is változást hozhat az érintett személyek hatalommal való felruházása által (Katona és mtsai, 2019).

A participatív kutatásoknak az alapelve, hogy minden embernek joga van beleszólni azokba a kutatásokba, kérdésekbe, amelyek az ő életére vonatkoznak. Ez a „semmit rólunk nélkülünk!” elv, ami a fogyatékosságügyi ENSZ egyezmény egyik legfontosabb értéke. Ennek a szemléletnek a megjelenése a tudományos munkában elősegíti a minél teljesebb társadalmi integrációt (Heiszer, 2011). A participatív kutatótárs megbízható informátor, akinek önálló, megalapozott véleménye van a saját és társai életét érintő kérdésekről (Marton \& Könczei, 2009).

A participatív kutatás lényege, hogy magában a kutatás folyamatában nem egyedül veszek részt, hanem bevonok a kutatás munkálataiba egy értelmi sérült személyt is. Ezáltal a kutatásban nem csak interjúalanyként jelennek meg értelmi sérült személyek, hanem kompetens szakértőként, egyenrangú félként is.

A kutatótárs részéről feltétel, hogy motivált legyen. Előnyös lehet, ha már van érdekvédelmi vagy önérvényesítő tapasztalata (Sándor, 2018). Cziráki Zsolttal először a 2019/20-as egyetemi tanév őszi félévében találkoztam. Ebben a félévben részt vettem az "Önkéntes munka értelmileg akadályozott személyekkel" című kurzuson, ahol többek között a gondnokság rendszeréről is szó esett. Mivel úgy éreztem, Zsolttal számos kérdésben egyetértünk, azonos értékrenddel rendelkezünk, így őt kértem fel participatív kutatótársamnak.

Zsolt megbízható, hiteles információkkal rendelkezik, hiszen maga is egy magyarországi, kisvárosi lakóotthonban él. Ahogy az önmagáról készített jellemzésben is olvasható, „vallja és hiszi is, hogy tudatosan képviselheti önmagát és a hasonló sorstársait is, illetve, hogy méltón és büszkén érvényesítheti szabadon az akaratát és így önmagát és közösségét is jól képviselheti. Participatív oktatóként segíti az egyetemi hallgatókat is a könnyen érthető kommunikációra történő felkészítésben" (Cziráki, 2020: o.n.).

A kutatás az első pillanattól kezdve participatív módon zajlott. Közösen határoztuk meg a kutatás célját és a kutatási kérdéseket, majd ezeknek megfelelően dolgoztuk ki a kutatás módszertanát. Ezalatt kölcsönösen tanulhattunk egymástól. A kapcsolattartás a vírushelyzet miatt többnyire az online térben zajlott, hang- és videohívásokon keresztül, valamint írásban kommunikáltunk egymással. A kommunikáció meglepően gördülékenyen működött ebben a formában is. Elöre megbeszélt alkalmakon, video- és hanghívás segítségével írtuk meg közösen a kutatásetikai elveknek megfelelő dokumentumokat. Tájékoztató levelet írtunk a kutatás céljáról és a megszólított személy feladatairól a kutatásba bevonni szándékozott személyek gondnokainak és maguknak a lakóotthon lakóinak is, utóbbi csoportnak könnyen érthetően. Az adatkezelési hozzájáruló nyilatkozatot a cselekvőképességet korlátozó gondokság alatt álló személyek helyett a gondnokok írták alá. Ugyanakkor az önérvényesítés és a „semmit rólunk nélkülünk” elvre figyelemmel fontosnak tartottuk, hogy a lakóotthonban élő értelmi sérült felnőttek is hozzájáruljanak az adatkezeléshez még akkor is, ha jogi értelemben ez nem az ő lehetőségük. Ezekben a nyilatkozatokban írásos hozzájárulást kértünk ahhoz, hogy az interjúba bevont személyektől 
gyűjtött adatokat és információkat kutatási céllal, a személyiségi jogok védelmére figyelemmel, anonim módon felhasználhassuk.

Elkészítettük az interjúkérdéseket is. Ezeket természetesen könnyen érthető módon állítottuk össze, a célcsoportnak megfelelő nyelvezettel. A könnyen érthető kommunikáció használatára a következő fejezetben térek ki.

Barthel (2004:185-186) szerint „A kommunikációjukban gátolt emberek megkérdezése során hasznos lehet, ha jelen van egy harmadik személy is, akivel a kérdezett bizalmas kapcsolatban van. Ö segíthet 'lefordítani' a számukra nehezebben értelmezhető közléseket. További előnye lehet, hogy az interjúalanynak biztonságérzetet ad jelenléte."

Ezt erősíti meg Katona (2013) is, aki szerint az interjúk felvétele során a kommunikációt segítheti, ha jelen van egy harmadik személy, például éppen a participatív kutatótárs, aki „tolmácsol”, azaz egyfajta kommunikációs hidat képez a kutató és a kutatás alanyai között.

Az online interjúk alatt Zsolt biztosította az internetkapcsolatot, az interjúkhoz szükséges eszközöket, és ő biztosította az interjúra alkalmas teret is. Az interjúk alatt, míg én egyedül voltam, a vonal másik végén Zsolt, illetve az interjúalany volt jelen. Kiegészítéseivel, javaslataival biztosította az eredményes kommunikációt. Az interjúk alatt, ha az interjúalany bizonytalan volt, Zsolt egy-egy biztató szóval, rávezető kérdésekkel garantálta az interjúalanyok közvetlenségét, a kérdésekre adott válaszok pontosságát. Ez számomra hatalmas segítséget jelentett. Végül minden interjú után közösen átbeszéltük a számomra kevésbé érthető válaszokat.

Zsolt az elemzés folyamatában is hasznos kutatótársként volt jelen. Véleményével, javaslataival, meglátásaival nagyban segítette a kutatás eredményeinek megfogalmazását is.

\section{A participatív kutatás és az önérvényesítés kapcsolata}

A participativ kutatás fontos eleme a feltárt tudás megosztásában való egyenrangú részvétel is (Katona és mtsai, 2019). Ugyanakkor az értelmi sérült kutatótárs verbális képességei, legalábbis kezdetben feltételezhetően elmaradnak a tudományos kutatás során elvárt nyelvi szinttöl. Ezért kiemelten fontos a minél hatékonyabb együttműködés érdekében, hogy a kutató alkalmazkodjon a kutatótársa nyelvi szintjéhez. Ennek meg kell jelennie mind az egyszerúbb nyelvi szerkezetek, mind az érthető szókincs használatában. Az értelmi sérült személyekkel való hatékony kommunikálás eszköze lehet a könnyen érthető kommunikáció, amelynek szóbeli és írásbeli változatát is érdemes érvényre juttatni.

2021. január 17-én a IX. Neveléstudományi és Szakmódszertani Konferencián lehetőségünk volt egy 15 perces előadásban bemutatni a kutatásunkat. Ezt szintén participatív módon, Zsolttal és témavezető tanárommal, dr. Horváth Péter Lászlóval közösen tettük meg. Az előadásnak nagy sikere volt. A zsürinek és a többi előadónak egyaránt elnyerte a tetszését a participatív előadásmód. Felülmúlhatatlan érzés volt ilyen módon előadni, hiszen ez is a participatív kutatásunk hitelességét támasztotta alá. A közös előadással hozzájárulhattam participatív kutatótársam önérvényesítéséhez is (Peszeki \& mtsai, 2021). 


\section{A KÖNNYEN ÉRTHETŐ KOMMUNIKÁCIÓRÓL}

Az értelmi sérült személyek közvetlen megkérdezésének nehézsége, hogy a bonyolult kifejezéseket, az idegen szavakat, hosszú kérdéseket igen nehezen tudják értelmezni. Minden esetben alkalmazkodnunk kell tehát az interjúalany nyelvi képességeihez. A kérdéseket úgy kell módosítani, átírni, hogy azok a résztvevők számára is könnyen érthetök legyenek.

A fogyatékosságügyi ENSZ egyezmény az akadálymentes kommunikáció fogalmába sorolja a taktilis kommunikációt, a Braille-nyomtatást, a hozzáférhető multimédiát, a nagyméretü betűkkel történő nyomtatást, valamint az írott és a hangzó, az egyszerü (vagyis könnyen érthetö) szövegeket, a felolvasást, illetve az augmentatív kommunikációt, beleértve a hozzáférhető kommunikációs és információs technológiákat és a kommunikáció egyéb alternatív módozatait (fogyatékosságügyi ENSZ egyezmény, 2006).

Bár a könnyen érthető üzenet készítése szabályrendszerének egységesítésére számos nemzetközi kísérlet történt, a legmeghatározóbb az Inclusion Europe és az ÉFOÉSZ által 2009-ben kiadott szabályrendszer (Inclusion Europe \& ÉFOÉSZ, 2009). Hazai szinten elsősorban ez az alapja a könnyen érthető produktumok készítésének, így participatív kutatótársammal ezen szabályok mentén dolgoztuk ki az interjú könnyen érthető kérdéssorát.

A könnyen érthető formában készült interjúkérdések első változatáról hamar kiderült, hogy bár Zsolttal közösen írtuk, ismerve az interjúalanyok képességeit, mégsem bizonyult megfelelőnek az interjúalanyok számára. Ebből adódóan az első két interjú - melyeket egy napon vettünk fel - kicsit hosszabbak voltak, mert a kérdéseket nehezebben értették. Ezen a ponton is segítségemre volt Zsolt, aki a bizonytalan, nehezebben érthető kérdéseknél könnyebben érthető megfogalmazást ajánlott. Így az interjúalanyok eredményesen tudtak válaszokat adni a kérdéseinkre. A két interjú után Zsolttal egyeztettünk arról, hogy mit és hogyan kellene módosítani a kérdéseken, és a következő helyzetekben már ezt a módosított kérdéssort használtuk. Ezt a kutatásunk során használt, félig strukturált interjú módszere engedte meg. A félig strukturált interjú módszerének a lényege, hogy elöre megírt kérdések alapján zajlik az interjú, de amennyiben az interjú menete megkívánja, a kérdéssortól eltérhet az interjúztató, új vagy részletesebb kérdéseket tehet fel (Lehota, 2001).

Participatív kutatótársammal végül minden interjú után megbeszéltük a tapasztalatokat, és szükség esetén újra egyszerüsítettünk a kérdéseken.

A könnyen érthető kommunikáció fontosságát azonban nem csak a kutatási eszköz kidolgozása és alkalmazása során nyert tapasztalatokkal lehet alátámasztani. Az interjúalanyok számos esetben jelezték, hogy igényt tartanának könnyen érthető anyagokra. Arra a kérdésre, hogy az érintett interjúalanyok min változtatnának a gondnokság rendszerében, a gondnokság lemondásának vágyán kívül több olyan javaslatot is kaptunk, hogy könnyen érthető segédletek, tájékoztatók, útmutatók segítségével az értelmi sérült személyek élete megkönnyíthető lenne. Ennek alátámasztására idézek az egyik interjúból:

77: kérdező: „És ezeket a gyógyszereket, amiket kaptál, ki váltotta ki? Te, vagy valaki más?"

78: válaszoló: „Nem, a nevelő. Vagy a gondnok, vagy a nevelő.” 
79: kérdező: „Rendben, köszönöm szépen. És ki tudnád-e váltani? Tudod-e a folyamatát, hogy hogyan kell?"

80: válaszoló: "Ha elmagyaráznád, biztos."

81: kérdező: Tehát akkor, ha lenne hozzá információd, akkor te magad is meg tudnád ezt csinálni, igaz?"

82: válaszoló: „Hát igen, ha elmondanák, akkor biztos, hogy ki tudnám váltani.”

(részlet a 9. interjúból)

\section{A könnyen érthetö kommunikáció és az önérvényesítés kapcsolata}

„Mivel az információ érték, birtoklása hatalmat ad birtokosa kezébe” (Slíz, 2012:14). „Az információ hatalom! Az információkhoz való egyenlő esélyű hozzáférés, az információk megértése feltétele annak, hogy tájékozódni tudjunk a világ dolgaiban. A tájékozódás során szerzett információkat felhasználjuk mindennapi döntéseink során. Amikor magunk hozunk döntéseket, akkor magunk rendelkezünk az életünk felett. Ezt nevezzük önrendelkezésnek. Vannak olyan emberek, akik kirekesztődnek az információkból, így nincs hatalmuk a saját életük felett. A hatalommal való felruházás egyik eszköze a könnyen érthető kommunikáció" (Horváth, 2020:21.).

Az önérvényesítők a könnyen érthető kommunikáció kiemelt szereplői. Ők azok, akik egyfelől igénylik a könnyen érthető információkat. Másfelöl az önérvényesítők között találunk olyan személyeket is, akik könnyen érthető információkat készítenek, és adott esetben képesek a mások által készített könnyen érthető információk könynyen érthetőségének az ellenőrzésére. Ilyen módon az önérvényesítők a könnyen érthető kommunikáció oktatásának egyik célcsoportját alkotják, illetve ők maguk is képessé válthatnak az önérvényesítés és a könnyen érthető kommunikáció oktatására (Horváth, 2020).

A könnyen érthető kommunikáció fontosságáról számos előadást hallhattunk az elmúlt években. Ilyen volt például az ÉFOÉSZ Önérvényesítő Csoportjának előadása a könnyen érthető kommunikáció és önérvényesítés témában. Sallai llona, az Önérvényesítő Csoport egyik alapító tagja az önérvényesítők munkáját és céljait mutatta be és hívta fel a figyelmet arra, hogy az önérvényesítés módszereinek átadásával lehet az érintetteket megtanítani a saját érdekeik képviseletére. Bercse László, az ÉFOÉSZ társelnöke az elöadáson a könnyen érthető kommunikáció alapelveit ismertette, szerinte a könnyen érthető hírek és cikkek elterjedésével a fogyatékossággal élők minél több és érthetőbb információhoz férhetnek hozzá, ami elengedhetetlen eszköze annak, hogy a társadalom aktív szereplőivé váljanak.

\section{ÖSSZEGZÉS}

Jelen tanulmány középpontjába a participatív kutatás, az önérvényesítés és a könynyen érthető kommunikáció elméletének és a gyakorlatának összekapcsolását állítottam.

A támogatott döntéshozatalról mint az önérvényesítés egyik lehetőségéről a kutatásba bevont értelmi sérült személyek kevés és nem feltétlenül mély ismeretekkel rendelkeznek. Ugyanakkor megfogalmazták igényüket arra vonatkozóan, hogy szí- 
vesen olvasnának könnyen érthető anyagokat például a pénzkezelésröl és a mindennapi tevékenységekről. Ha ezeket az anyagokat elkészítenénk, úgy a participatív kutatótásammal immáron participatív oktatótársként tréningeket, képzéseket, előadásokat tarthatnánk a lakóotthon lakóinak. Bízom abban, hogy erre lesz lehetőségem a jövőben.

\section{Irodalom}

a Fogyatékossággal élő személyek jogairól szóló ENSZ egyezmény, 2006

az Országos Fogyatékosságügyi Programról (2015-2025) szóló 15/2015. (IV. 7.) OGY határozat a Polgári Törvénykönyvröl szóló 2013. évi V. törvény

Barthel B. (2004). Értelmileg súlyosan akadályozott és halmozottan sérült emberek véleményének kikérése. Gyógypedagógiai Szemle, 32.3:184-190.

https://epa.oszk.hu/03000/03047/00026/pdf/EPA03047_gyosze_2004_3_184-189.pdf Letöltés ideje: 2021.03.08.

Bercse L. \& Czakó T. (2019). Önérvényesités és önálló életvitel. Kézirat.

Budai I. \& Puli E. (szerk.) (2012). Együttmüködés a szociális szolgáltatásokban. Széchenyi István Egyetem, Györ.

Cziráki Zs. (2020). Gondolatok az önérvényesítésröl a participatív kutatással kapcsolatban. Kézirat.

ÉFOÉSZ (2020): Az ÉFOÉSZ honlapja. https://efoesz.hu/ Letöltés ideje: 2021.03.08.

Gazsi A. (2016). A támogatott döntéshozatal elve és gyakorlata. Esély, 2016.2:62-92.

Heiszer K. (2011). Új fogyatékosságtudományi kutatási irányzatok Williams szindrómás fiatalokkal. ELTE Bárczi Gusztáv Gyógypedagógiai Kar, Budapest.

Horváth P. L. (2013). Társadalmi integráció és fogyatékosságügyi politika. In Zászkaliczky P. (szerk.), A társadalmi és az iskolai integráció feltételrendszere és korlátai. ELTE Bárczi Gusztáv Gyógypedagógiai Kar, Budapest. 11-57.

Horváth P. L. (2020). A könnyen érthetö kommunikációs képzési programok képzésfejlesztésének története Magyarországon a fogyatékossággal élő személyek jogairól szóló ENSZ egyezmény tükrében. (Doktori értekezés.) Eszterházy Károly Egyetem Neveléstudományi doktori iskola, Eger.

Horváthné Somogyi I., Danó R. \& Tóth Sz. (2011). Támogatott döntéshozatal. Az ÉFOÉSZ modellkísérleti programjának tapasztalatai. Inclusion International - ÉFOÉSZ, Budapest.

Inclusion Europe \& ÉFOÉSZ (2009a). Információt mindenkinek! A könnyen érthető kommunikáció európai alapelvei. Inclusion Europe - ÉFOÉSZ, Brüsszel - Budapest.

Jakab N. (2011): A támogatott döntéshozatal elméleti és gyakorlati kérdései Kanadában. Sectio Juridica et Politica, 29.2:435-459.

Kaló C. G. \& Horváth P. L. (2019). Látkép a támogatott és a helyettes döntéshozatal helyzetéröl. Fogyatékosság és Társadalom. 2019.2:100-119. https://doi.org/10.31287/FT. hu.2019.2.7

Katona V. (2013). Felnőtt értelmi fogyatékos személyek életútjának feltérképezése. In Zászkaliczky P. (szerk.), A társadalmi és az iskolai integráció feltételrendszere és korlátai. ELTE Eötvös Kiadó, Budapest. 117-177.

Katona V., Cserti-Szauer Cs. \& Sándor A. (szerk.) (2019). Együtt oktatunk és kutatunk! Inkluzív megközelités a felsőoktatásban. ELTE Eötvös Kiadó, Budapest. 113-174.

Központi Statisztikai Hivatal (2012). Statisztikai Tükör. VI.45. Központi Statisztikai Hivatal, Budapest.

Lehota J. (2001). Marketingkutatás az agrárgazdaságban. Mezőgazda Kiadó, Budapest.

Marton K. \& Könczei Gy. (2009). Új kutatási irányzatok a fogyatékosságtudományban. In Fogyatékosság és társadalom 2009.1:5-12.

Peszeki D. (2021): A gondnokságról alkotott vélemény: elöny vagy hátrány? (TDK-dolgozat.) SZTE Juhász Gyula Pedagógusképző Kar Gyógypedagógus-képző Intézet, Szeged.

Peszeki D., Cziráki Zs., Horváth P. L. (2021). A gondnokság intézménye az érintettek szempontjából: Előny vagy hátrány? In Karlovitz János Tibor (szerk.), IX. Neveléstudományi és Szakmódszertani Konferencia (2021): Program. Tartalmi összefoglalók. Vzdelávacia, výskumná a metodická konferencia. 71. http://www.irisro.org/9programabsztraktNSZK2021.pdf Letöltés ideje: 2021.03.09. 
Rappaport, J. (1987). Terms of empowerment/exemplars of prevention: Toward a theory of community psychology. American Journal of Community Psychology, 15.2:121-145. https:// doi.org/10.1007/BF00919275

Roberts, E. (2020). Az önérvényesítés mozgalmának atyja, Ed Roberts élete és munkássága. https://artsandculture.google.com/exhibit/VwLy4PBo_Ty9Jg Letöltés ideje: 2021.03.08.

Ruzsics I. (2013). A kitagolás folyamatai Európában és Magyarországon. http://www.jgypk.hu/ mentorhalo/tananyag/kitagolas/index.html Letöltés ideje: 2021.03.08.

Sadan, E. (2011). Közösségi tervezés és empowerment. ELTE Társadalomtudományi Kar, Budapest. https://docplayer.hu/36303097-Kozossegi-tervezes-es-empowerment.html Letöltés ideje: 2021.03.08.

Sándor A. (2018). „Az együttgondolkodásból fakadó többlettudás az értelme.” Az inkluzív kutatás módszertana egy fogyatékosságtudományi kutatás tapasztalatai tükrében. Gyógypedagógiai Szemle, 46.1:12-32.

Slíz M. (2012). Az információ hatalom. Az információ hétköznapi metaforái. AETAS Történettudományi folyóirat, 27.4:13-21.

Verdes T. \& Tóth M. (2008): A per tárgya. ELTE BGGYK - ELTE Eötvös Kiadó, Budapest.

\section{További olvasmány az ELTE Bárczi Gusztáv Gyógypedagógiai Kar kiadásában}

\section{Hogy értsük egymást}

Ez a kötet olyan tanulmányokat tartalmaz, amelyek segítséget nyújthatnak az intellektuális képességzavarral élő személyek kommunikációfejlesztése során.

A kötet első részében szereplő tanulmányokat a gyakorlatban dolgozó kollégákon kívül BA képzésben részt vevő, értelmileg akadályozottak pedagógiája és logopédia szakos hallgatók figyelmébe ajánljuk. Az írások foglalkoznak az augmentatív és alternatív kommunikációval, a korai és iskoláskori fejlődés-fejlesztés szempontjaival, az iskolai fejlesztésre vonatkozó fejezet pedig nemcsak konkrét módszerekkel és feladatokkal, hanem az egyes szintek (helyi tanterv, tematikus

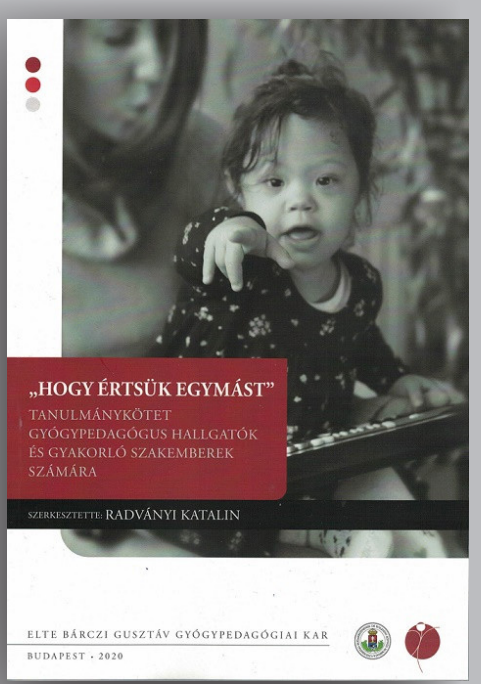
terv) konkrét példáinak bemutatásával is segíti az eligazodást.

A kötet második részében szereplő tanulmányok neurokognitív és pszicholingvisztikai szempontok oldaláról közelítve tárgyalják a nyelvi zavarok és genetikai szindrómák kutatását, melyek az MA képzésben tanulók számára is hasznos és új információkat tartalmaznak.

A kötet szerkesztője Radványi Katalin, szerzői között találjuk Kálmán Zsófiát, Juhász Ágnest, Radványi Katalint, Pál-Horváth Ritát, Földesiné Czövek Klárát, Csépe Valériát és Pléh Csabát. 


\title{
A könnyen érthető kommuniká- ció mint innováció megjelenése az integrált nevelési-oktatási folyamatban
}

\begin{abstract}
A tanulmányban - szemle jelleggel - egy falusi, tanulásban akadályozott tanulók számára inkluzív nevelést biztosító általános iskolában bevezetett módszertani innováció bemutatására kerül sor. Célunk annak szemléltetése, hogy a többségi és a tanulásban akadályozott tanulók együttoktatása hogyan valósítható meg könnyen érthetö oktatási segédanyagok készitésével. A fejlesztés eredményeként átalakulhat az együttnevelést segítö pedagógus kompetenciája: a tanuló osztályközösségből történő kiemeléséről és egyéni fejlesztéséröl a hangsúly áthelyeződik a többségi pedagógussal történő együttműködésre, a többségi pedagógus által az osztálytermi differenciálást lehetővé tevő könnyen érthető oktatási segédanyagok létrehozására. A tanulmányban kitérünk a tanulók tudásmérését szolgáló eszközök adaptálásának szükségességére is. A módszer alkalmazásába bekapcsolódó pedagógusok és tanulók véleménye, valamint szisztematikus megfigyeléseim alapján úgy tủnik, hogy a könnyen érthető kommunikációval a tanulók jól motiválhatók olvasási feladatok elvégzésére, eredményesebbekké válnak, fokozható a teljesítményük.
\end{abstract}

Kulcsszavak: könnyen érthetö oktatási segédanyag, demokratikus jogok, esélyegyenlőség, inkluzív nevelés, együttnevelést segitő pedagógus kompetenciája, együttmüködés, innováció

Jelen tanulmányban egy falusi, tanulásban akadályozott tanulók együttnevelésére vállalkozó integráló iskolában megvalósított innovációt mutatok be. Az iskola tanáraival arra vállalkoztunk, hogy elkészítjük a tanulásban akadályozott tanulók számára sokszor nehezen értelmezhető iskolai tankönyvek szövegének könnyen érthető változatát, majd ezeket a tanórai differenciálás eszközeként a szaktanárok aktív szerepvállalása mellett bevezetjük a tanórákon. A fejlesztés eredményeként lehetőség nyílik arra is, hogy lassan megváltozzon az együttnevelést segítő pedagógus kompetenciája: az osztálytermen kívüli egyéni fejlesztésröl áthelyeződik a hangsúly a könnyen érthető oktatási segédanyag készítésére, valamint a szaktanárokkal való együttműködésre.

Régóta keresem a lehetséges utakat, hogy az integráció iskolánkban minél eredményesebb legyen, illetve az intézményben folyó nevelés-oktatás egyre inkább az inklúzió felé mutasson. Azt gondolom, hogy olyan új megközelítést mutathatok be, ami mintaként szolgálhat a pedagógusok és a gyógypedagógusok számára.

Az ELTE Bárczi Gusztáv Gyógypedagógiai Karon a gyógypedagógus-szakvizsga szakirányú továbbképzés keretében ismerkedtem meg a könnyen érthető kommunikációval. Ekkor kezdett el foglalkoztatni a gondolat, hogy az iskolánkba járó tanulásban akadályozott tanulók körében is kipróbálom a könnyen érthető kiadványokat. Első lépésként, még a képzés keretében, az akkori csoporttársaimmal közösen készítettük el a természetismeret tantárgy tanulásának segítése érdekében az „Anyagok a környezetünkben” című lecke könnyen érthető változatát, amit ki is próbáltunk. A gyermekek nagyon motiváltak voltak. Az olvasás sikerélményt nyújtott számukra. A szöveg megértéséről feladatlap kitöltésével győződtünk meg. Ekkor 
gondolkodtam el azon, hogy talán még a kifejezetten a sajátos nevelési igényű tanulók számára szerkesztett tankönyvek szövegének a megértése is gyakran problémát okoz. A gyermekek véleménye ebben teljes mértékben megerősített. Ők voltak azok, akik újabb és újabb könnyen érthető kiadványok megírására ösztönöztek.

2017 óta több témában is készítettem könnyen érthető segédanyagokat. Igyekeztem minél több pedagógustársamat bevonni az innovációs folyamatba. Sokan és szívesen próbálták ki a felsőtagozaton tanító szaktanárok közül az elkészült anyagokat. Néhány könnyen érthető oktatási segédanyag témakörének meghatározására már a kollégákkal közösen került sor. Ma már elmondhatom, hogy egyre többen keresnek meg azzal a kéréssel, hogy segítsek egyes tantárgyrészek könnyen érthető átírásában.

A továbbiakban bemutatom az innovációs folyamatnak terepet biztosító általános iskolát. Röviden írok a tanulókról és a pedagógusokról. Ezt követően ismertetem a könnyen érthető oktatási segédanyagok keletkezésének folyamatát. Beszámolok a termékek kipróbálásának tapasztalatairól is. Végezetül szubjektív módon, a fejlesztésben érintett szereplőként értékelem az eredményeket, valamint számba veszem a könnyen érthető kommunikáció további alkalmazásának lehetőségeit.

\section{AZ INNOVÁCIÓS FOLYAMATNAK TEREPET BIZTOSÍTÓ ÁLTALÁNOS ISKOLA BEMUTATÁSA}

Településünk Békés megye csücskében helyezkedik el. A családok többsége alkalmi munkákból, illetve segélyekből él. A szülők - mivel lehetőségeik korlátozottak - ragaszkodnak a helyi általános iskola adta feltételek és lehetőségek kihasználásához. Nem szeretnék gyermekeiket a tölünk 20 km-re lévő, szegregált iskolába járatni. Ha lehetséges, akkor a szülők a helyi általános iskola integrált nevelését-oktatását választják.

Nagyon sok halmozottan hátrányos helyzetủ tanulónk van. A tanulók létszáma 202 fő. Ebből 33 fő (16 százalék) beilleszkedési, tanulási, magatartási nehézséggel diagnosztizált. 28 fő (14 százalék) sajátos nevelési igényű tanuló. Intézményünk egyébként 2005 óta vállalja a sajátos nevelési igényű gyermekek ellátását.

A sajátos nevelési igényű tanulók közül 1 fő mozgássérült, 2 fő tanulásban akadályozott, 25 fönél pszichés fejlődési zavart állapítottak meg. Közülük a 2018/19. tanévben 13 fő tanult eltérő tanterv szerint, az alsó tagozatban pedig 3 fö egyéni tanrend szerint haladt.

Iskolánkban a részleges integráció valósul meg. Ez azt jelenti, hogy csak az iskolában töltött idő egy részében, kizárólag egyes tanórákon vesznek részt a sajátos nevelési igényű gyermekek a többiekkel. A készségtantárgyak tanóráin minden esetben az osztályban vannak. Az eltérő tanterv szerint haladó tanulók évfolyamonként heti 8 órában gyógypedagógus által tartott órákon vesznek részt. Ezeken az órákon többnyire az új ismeretek átadását valósítjuk meg. Az egészségügyi és pedagógiai célú habilitációs és rehabilitációs órák megtartására délutáni időpontban kerül sor.

Az iskolánkban ketten dolgozunk gyógypedagógusként, mindketten együttnevelést segítő szakemberek vagyunk. Azokon az órákon, amikor együtt vannak a sajátos nevelési igényủ tanulók ép társaikkal, a szaktanárok a tanítás folyamatát az egyéni igényekhez illesztve differenciáltan szervezik. A differenciálás mértékét és módját 
a gyógypedagógus és a szaktanár előzetes egyeztetése határozza meg. Tantestületünkre egyre inkább jellemző az integráció szempontjából fontos, a korábbi évekhez képest megváltozott szemléletmód. Nagyon fontosnak tartjuk a differenciálást, illetve a szaktanár és a gyógypedagógus közötti szoros, szakmai együttmüködést. Lényeges, hogy a pedagógusok minden tanulóban a speciális szükségletet, a tanulóra jellemző egyéni sajátosságokat, erősségeket keressék és lássák meg. Alapvető célnak tekintjük, hogy a sajátos nevelési igényű tanulók ne csak jelen legyenek a tanórákon, hanem a tanulási folyamatok aktív részeseivé váljanak.

\section{A KÖNNYEN ÉRTHETŐ OKTATÁSI SEGÉDANYAGOK KELETKEZÉSÉNEK FOLYAMATÁRÓL}

A könnyen érthető oktatási segédanyagok készítésének folyamatát időrendben mutatom be.

Írásom ezen része egyfajta esettanulmány, aminek a célja, hogy a módszertani lépések bemutatása mintaként szolgálhasson az olvasó számára.

Elöször az Anyagok a környezetünkben című oktatási segédanyag készült el az egyetemi képzésben előírt projektmunka követelményének teljesítéseként. Az eredeti szöveget a harmadik osztályos általános iskolás tanulók számára írt környezetismereti tankönyvből vettük.

Ezt követően tizenegy könnyen érthető oktatási segédanyagot készítettem még.

Az első, önállóan készített könnyen érthető tananyag akkor született meg, amikor az egyik magyar nyelv és irodalom szakos tanárnő az iskolánkban készült a minősítő értékelésére. Az akkori csoportjában volt 3 fő tanulásban akadályozott tanuló. Itt szeretném megjegyezni, hogy a tanulásban akadályozott tanulóink egy része az általános iskolás tanulók számára írt tankönyvböl tanul. Vannak olyan tanulásban akadályozott tanulók is, akik a számukra készített tankönyvekből sajátítják el az ismeretanyagot. Azt, hogy melyik gyermekcsoport melyik tankönyvet használja, mindig az osztályban tanító pedagógusokkal egyeztetjük, figyelembe véve a a tanulók képességi szintjét. Természetesen ez sokkal nagyobb összhangot, több egyeztetést igényel a szaktanár és a gyógypedagógus között az egész tanítási folyamatban. A tanárnő segítséget kért tőlem, miként tudná az órán a differenciálást, az egyéni segítségadást megvalósítani olyan módon, hogy az a lehető leghatékonyabb, legösztönzőbb legyen a gyermekek számára az órák folyamán. A tanárnő már látta az előzőleg elkészült könnyen érthető oktatási segédanyagot. Ezért ez a lehetőség is felmerült benne. Egyeztettük a témát, az óra célkitüzését. Ő adta a magyar irodalmi szakmai tudást, én pedig ehhez próbáltam illeszkedni gyógypedagógiai szemléletemmel, tudásommal. Így készült el Radnóti Miklós élete és a „Nem tudhatom” című versének elemzése könnyen érthetően. A nyelven belüli fordítás alapját részben a 8. évfolyamos tankönyvi szöveg képezte, részben az interneten kerestem meg a pontos életrajzi adatokat. Ugyanakkor a vers eredeti formában került a szövegbe, mert álláspontom szerint verset nem érdemes könnyen érthető nyelvi szintre fordítani: így ugyanis elvesztené eredeti szépségét. Versek esetében inkább a vers egyfajta értelmezését lehet könnyen érthetően elkészíteni. A könnyen érhető anyag 
felhasználásával megtartott óra a pedagógus elmondása alapján sikeres volt. A tanulók a tölük elvárható mértékben voltak részesei a tanítási folyamatnak. Az akkor elkészült Radnóti-segédanyagot a későbbiekben is használta a tanárnő.

A magyar szókincs témakört átfogó könnyen érthető segédanyag is a fent említett tanárnővel való közös munka eredménye. Tanév vége felé beszélgettünk arról, hogy a magyar nyelv tantárgyban mi az a mindennapi élethez köthetö témakör, ami a tanulásban akadályozott, 8. évfolyamos tanítványaink szempontjából is kiemelt fontossággal bír. Ekkor jött az ötlet, hogy az általános iskolások számára készült tankönyvben szereplő, a magyar szókincsről szóló szöveget jó volna ismét könynyen érthető módon a gyermekek számára átírni. A munka folyamata az előző közös munkánkhoz hasonló volt. A lényeges információkat közös megbeszélés alapján határoztuk meg. Ezt követően átírtam a szöveget, majd a könnyen érthető szöveg első változatát közösen értékeltük. A tanulóknak ekkora már szinte természetes volt, hogy könnyen olvasható szöveget olvasnak és értelmeznek.

A Tóték és a Tündér Lala könnyen érthető változatának keletkezése kissé eltér az eddig leírtaktól. A fejlesztő órámon a tanítványaimmal az iskolai szintű hangos olvasás felmérésére készültünk. Ekkor fogalmazták meg maguk a tanulók az igényüket, hogy olyan szöveget szeretnének olvasni, mellyel képességeiknek megfelelően tudnak boldogulni. Elmondták azt is, hogy nem szeretnének rossz jegyet kapni, de nem szeretnének kirekesztődni sem a mérésből. A beszélgetés után egyértelművé vált, hogy ez a mérés bizony érzelmileg is nagyon megterhelő nekik. Mi, felnőttek sem szeretünk olyan helyzetbe kerülni, amikor már elöre tudjuk, hogy az az adott tevékenység kudarcos lesz számunkra. Ekkor gondoltam arra, hogy ezt megbeszélem az iskola vezetőségével, illetve a mérésben érintett pedagógusokkal. A cél az volt, hogy a tanulók részeseivé válhassanak a mérésnek. Ennek érdekében az eredeti szöveget, amit a mérés során a normál fejlődésmenetű gyermekek olvasnak, átírtam könnyen érthető szöveggé. Azért választottam az átíráshoz ugyanazt a szöveget, hogy a gyerekek ne megkülönböztetettként vegyenek részt a mérésben, hiszen azonos tartalmú szöveg olvasását várják el tölük is.

A pedagógiai programunkban megjelenő intézményi értékelési rendszer tartalmazza, hogy minden tanév végén, minden évfolyamon, szummatív mérést kell tanulóinkkal végezni a szövegértés területén is. Ezt a mérést a szakmai munkaközösségek irányítják, a felső tagozaton a humán munkaközösség vezetője koordinálja a szövegértés-felmérés tartalmát is. Ennek a mérésnek azért is nagy a jelentősége, mert képet mutat a tanítás-tanulás hatékonyságáról. Ugyanakkor alkalmat ad arra, hogy a tanulók egyéni eredményeit korábbi teljesítményeikhez viszonyítsuk. Így született meg az a gondolat, hogy - a munkaközösség vezetőjével egyeztetve elkészüljön a 6. évfolyamon a szövegértést felmérő feladatsor könnyen érthető változata. A szöveg kiválasztásakor és a feladattípusok meghatározásakor az egyik fő cél az volt, hogy a gyermekek munkavégzése beleférjen a 45 perces időkeretbe. A szöveg választásában még azt is szem elött kellett tartanom, hogy abban a tanévben elvárás volt, hogy lehetőleg ismeretterjesztő szöveg felhasználásával történjen a mérés. Ezért az adott ismeretterjesztő szöveget rövidebben fogalmaztam meg, illetve a szöveg átírása során a könnyen érthető kommunikáció módszertanát is figyelembe vettem. A feladattípusok kiválasztásában a fő szempontom az volt, hogy az értékelés után meg tudjak győződni arról, hogy a gyermekek képesek az olvasást felhasználni az információszerzésre, a lényeget meg tudják ragadni, tudnak össze- 
hasonlítani, értelmezni, elemezni. A szöveg egy foglalkoztató munkafüzetben volt fellelhető, a feladatokat az érintett tanulók képességeinek megfelelöen válogattam össze. Így született meg A farkasok, valamint a hozzá tartozó feladatlap könnyen érthető változata.

A következő könnyen érthető termék már a 2018/2019. tanév elején készült. A 8. évfolyamra négy tanulásban akadályozott tanuló járt. A történelem tantárgy tanulását segítő segédanyag A világ az 1920 -as és 1930 -as években, illetve A második világháború utáni történelem címmel készült el. Ez a könnyen érthető oktatási segédanyag egy teljes történelmi témakört dolgoz fel. Ennek a szövegnek a fordítása volt a legtöbb időt igénylő munka, elsősorban a terjedelme miatt. Nagyon sok szakmai egyeztetésre volt szükség a történelem szakos tanárnővel. Ezért úgy döntöttünk, hogy a gyermekek minden órán megkapják az adott tananyaghoz kapcsolódó részt. A szakos tanárnő a tantárgyi tudását adta, én pedig már bátrabban mertem érvelni a könnyen érthetően szerkesztett mondatokat, fogalomleírásokat illetően. Tulajdonképpen részekből alakult ki az egész. A folyamat végén, a rendszerezéskor, az összefoglalás során lett teljes a gyermekek számára a fejezet. $A z$ elkészült írásokat folyamatosan lefüzték egy mappába. A szöveg a 8. osztályos, általános iskolai történelem tankönyv alapján készült el, a térképek és a képek az internetről származtak.

Az óceánok és tengerek című könnyen érthető oktatási segédanyag egy szakmai segítségkérés eredményeként született. A 7. évfolyamon három tanulásban akadályozott tanuló tanul a számukra készített tankönyvekből. Az ezen az évfolyamon tanító földrajz szakos tanár ebben a tanévben kezdte meg a munkáját intézményünk felső tagozatán, ekkor ismerte meg az általa tanított gyermekcsoportot. Az integrált nevelés-oktatás hatékony megvalósítása érdekében már többször kért tanácsot tőlem. A belső önértékelés folyamatában az adott tanévben került sor arra, hogy a kolléga óráját értékeljék. Nagyon tanácstalan volt abban, hogy miként tudja leginkább bevonni az érintett tanulókat a többi tanulóval egyidejüleg a tanulási folyamatba. Mivel a bemutató órára tervezett témakör a három tanuló tankönyvében nem szerepelt, ezért úgy gondoltuk, hogy a legjobb lenne, ha ők is a többiekkel azonos időben olvashatnák a témát leíró szöveget. A fordítás alapját itt a 7. évfolyamos földrajz tankönyv szövege képezte.

A következő könnyen érthető termék a Testünk és egészségünk, illetve az ehhez a témakörhöz tartozó feladatlap. A 4. évfolyamon tanító kolléganőm kért tanácsot azzal kapcsolatban, hogy miként kérje számon a tanulásban akadályozott tanulóktól a megtanított tananyagot. Az integrált oktatásban már volt tapasztalata, de bevallása szerint a számonkérés módja, a felmérők feladatainak differenciálása némi bizonytalanságot okozott számára. Különösen azért, mert az egyik kislánynak nagyon nehezen ment az olvasás, a feladatok értelmezésében bizonytalannak tủnt, sok segítséget igényelt. Ezért döntöttünk úgy, hogy a 4. évfolyamos tankönyv szövegét átírom könnyebben érthetőre.

A 2019/2020-as tanév elején felmerült bennem a gondolat, hogy ne csak egyes tananyagrészek könnyen érthető változatát készítsük el, hanem oktatási segédanyagként, az érintett szaktanárral egyeztetve próbáljuk meg az általános iskolások számára íródott ötödik évfolyamos történelem tankönyv egészét könnyen érthetővé tenni. Ezt a munkát el is végeztük. Ugyanakkor az anyagot ebben a tanévben ismét át kell dolgozni az új NAT-tal együtt megjelent, annak megfelelő ötödik 
osztályos történelem tankönyvre tekintettel. Nagyon sok szakmai egyeztetésre volt szükség a történelem szakos tanárnővel. Ezért úgy döntöttünk, hogy a gyermekek mindig az aktuális órán kapják meg az adott tananyaghoz kapcsolódó részt. Ebben az innovációban a tudásmegosztás szintén kétirányú volt: a történelem szakos tanárnő a tantárgyi tudását adta, én pedig érvényesítettem a segédanyag írásakor a könnyen érthető kommunikáció szabályrendszerét. A segédanyagot folyamatosan igazítottam, javítottam. A készítés folyamatáról elmondható, hogy részekből alakul ki az egész: vagyis az egyes témakörök végén, a rendszerezéskor, az összefoglalás során lesz teljes a gyermekek számára az adott fejezet. Az elkészült írásokat folyamatosan lefüztük egy mappába. A szöveg (ahogy említettem is) az ötödik osztályos, új történelem tankönyv alapján készült, a térképek, képek részben tankönyvből, részben internetről származnak. Az elkészült munkából egy fejezet a tanulmány mellékletét képezi (1. sz. melléklet). Nagy örömömre szolgál, hogy a könnyen érthető oktatási segédanyag használata a történelem tanórán mára iskolánkban intézményi jó gyakorlattá vált.

\section{A KÖNNYEN ÉRTHETŐ OKTATÁSI SEGÉDANYAGOK ALKALMAZÁSÁNAK TAPASZTALATAI}

Ebben a fejezetben azokról a tapasztalatokról szeretnék számot adni, amelyeket a könnyen érthető oktatási segédanyagok felhasználása során szereztünk. A tapasztalatokról az innovációs folyamatban közvetlenül részt vevő pedagógusokkal és a tanulókkal beszélgettem. Részt vettem továbbá néhány olyan órán, ahol a szaktanárok beépítették a könnyen érthető oktatási segédanyagokat a tanítási óra folyamatába. Az így szerzett tapasztalatok természetesen teljesen személyesek, és nem egy tudományos kutatás eredményei.

A szaktanárok korábban nem ismerték a könnyen érthető kommunikáció módszerét, a könnyen érthető kiadványokról sem volt előzetes ismeretük. A közös munka során sokszor kiemelték a partnerség, a közös gondolkodás, az együttmüködés fontosságát, ami véleményünk szerint növeli az integrált nevelés-oktatás hatékonyságát. A szakoktatókat örömmel és elégedettséggel töltötte el, hogy az innovációs folyamatnak maguk is részesei voltak. Nem egy kész terméket kaptak, hanem szaktudományos ismereteikkel maguk is hozzájárultak az oktatási segédanyagok készítéséhez.

Egyes pedagógusok szerint a könnyen érthető oktatási segédanyagok sikeres alkalmazásához szükséges az osztálytársak toleráns hozzáállása is.

Lényegesnek találták, hogy a tanulókat sokkal könnyebben tudták bevonni az órai munkába. A tanulókat könnyű volt motiválni, szívesen használták a könnyen érthető tananyagot. Úgy tủnt, hogy nem volt zavaró, hogy nem a megszokott tankönyvet használták. A pedagógusok szerint érezhetően és pozitívan változott az olvasáshoz való hozzáállásuk, a szereplési aktivitásuk, a magabiztosságuk növekedett. Kevesebb gátlás jellemezte a tanulók olvasását. Az érintett diákok mertek hangosan olvasni. Még az a gyerek is vállalta a hangos olvasást, akit eddig erre nem lehetett rávenni tanórai keretek között. A tanulók szívesen olvasták a számukra is érthető 
segédanyagokat, mert egyszerű és rövid mondatokkal találkoztak a szövegben. Kiemelték, hogy valószínüleg a betűméret és a sorok hossza is megkönnyíthette az értő olvasást. A szaktanárok többsége úgy tapasztalta, hogy a magyarázó erejü, tehát nem illusztrációs célú képi támogatás is elősegítheti a megértést.

Az integrált oktatás során nem csak az egyéni feladatok végzésében voltak aktívak az érintett tanulók, hanem a frontális osztálymunkában is tevékenyebben vettek részt.

Úgy tünik, hogy a könnyen olvashatóan szerkesztett tananyag olvasása, a könynyen érthetően megszövegezett üzenet megértése sikeresnek bizonyult, hiszen az olvasott információkat megértették. A gyerekek magabiztosabb olvasása pozitív hatással lehet a memorizálás folyamatára is.

Többek szerint az érintett diákok kifejezetten örültek a rájuk szabott figyelemnek és törődésnek.

A könnyen érhető oktatási segédanyagból megtanult ismeretek számonkérése többféle módon történt. Így például akár könnyen érthetően szerkesztett dolgozat formájában is adhattak számot a tudásukról. Minden kolléga arról számolt be, hogy a számonkérés ezen módja sikeresebbnek és eredményesebbnek bizonyult a korábbiaknál. A gyerekek sikeresebben tudtak felkészülni a könnyen érthető oktatási segédanyagokból a szóbeli feleletre, illetve a dolgozat megírására.

Összességében úgy tünik, hogy a könnyen érthető oktatási segédanyagok jól beilleszthetők az intézményben folyó integrált nevelési-oktatási folyamatba. A tanulásban akadályozott tanulók is ugyanazt a tananyagot tanulhatják, mint az osztálytársaik, csak számukra hozzáférhető és értelmezhető formában. Ez a módszer azért is hatékony, mert a tanulók aktív résztvevői válnak az óráknak, és a tudáspróbák teljesítése is több sikerélményt okoz mind a tanulóknak, mind pedig a szaktanároknak.

A könnyen érthető kommunikáció módszere a kollégák többsége szerint nem csak a tanulásban akadályozott tanulók esetében hasznos. Az osztályba járó, de alacsonyabb nyelvi kompetenciájú tanulókkal is jól tudják alkalmazni.

\section{A TANULÓK VÉLEMÉNYÉRŐL}

1. „A képek segítettek.”

2. „A könyvben a szó nagyon hosszú és nehéz."

3. „Amit nem annyira bírtam kiolvasni, abban segített a tanító néni."

4. „Azért volt könnyü, mert a végén is emlékeztem arra, amit az elején olvastam.”

5. „Elolvastam és jelentkeztem.”

6. „Izgultam a felmérőnél, mert nem tudtam, hogy milyen lesz. Megörültem, hogy könnyü, nem olyan nehéz, mint a többieknek."

7. „Jó, hogy legalább már meg tudom csinálni."

8. „Jó, mert kevesebb volt a lap, nagyobb a betű."

9. „Könnyebb volt, mert ha egyszer is elolvastam, megértettem.”

10. „Könnyebben elolvastam a feladatokat.”

11. „Könnyebben értelmezhető volt.”

12. „Könnyebben lehetett készülni és megtanultam.”

13. „Könnyü, mert rövidebb volt, jobban lehetett érteni."

14. „Nagyobb bennük a betük, meg a képek is jók.” 
15. „Nem kellett kikeresni, mert ki volt írva a fontos.”

16. „Nem olyan kicsik a betűk, meg hogy jól ki lehetett olvasni, mert nem egybe voltak."

17. „Órákon is figyeltem, meg a szövegből megtanultam."

18. „Rövidebb mondatok voltak.”

\section{ÖSSZEFOGLALÁS}

A tanulmányban bemutatott innováció egyik fö eredményének tekintem, hogy iskolánkban összesen 12 darab könnyen érthetöen szerkesztett tananyagból 13 tanulásban akadályozott tanuló 5 különböző szakos pedagógus segítségével tanulhatott a tárgyalt másfél év alatt. Úgy érzem, hogy ez a fejlesztés közvetlenül hozzájárulhat az érintett gyerekek önérvényesítéséhez, közvetve pedig az integráció eredményesebb megvalósulásához.

Minden embernek, így az oktatásban részt vevő tanulásban akadályozott tanulóknak is demokratikus joguk, hogy hozzáférhessenek az információhoz. Ezért is tartom nagyon fontosnak, hogy legyenek könnyen érthető oktatási segédanyagok. Azt gondolom, hogy ezzel biztosítható az oktatási folyamathoz való egyenlő esélyű hozzáférés a sajátos nevelési igényủ gyermekek és tanulók számára.

Bízom abban, hogy a könnyen érthető kommunikáció hangsúlyossá válhat az integrált nevelés-oktatás folyamatában.

Ez a fajta innováció pozitív hatással lehet a szakmai párbeszédre a helyi közösségünkben. Ebben a folyamatban mindenkinek jut szerep. Valódi team-munka alakulhat ki.

Egyéni szinten hozzájárulhat a tipikus fejlődésmenetủ tanulók toleranciájának és empatikus viselkedésének megerösödéséhez.

Különösen fontosnak tartom, hogy a tanulásban akadályozott tanulók motiválására is alkalmas. Azt gondolom, hogy gyógypedagógusként fontos feladatunk mindent megtenni annak érdekében, hogy az adott osztályba járó minden tanuló megérthesse az őt körülvevő világot.

Remélem, hogy sikerült szemléltetni, milyen nagy lehet a jelentősége ennek az innovációs folyamatnak egy falusi iskolában.

Tanulmányomat egy témához illő idézettel szeretném zárni:

„Az egyik leghatékonyabb dolog, amit tehetünk, hogy hallgatunk gyermekeinkre és megtaláljuk az utat egyedi képességeik támogatására.

Ha megadjuk gyermekeinknek a magabiztosságot, azzal segithetünk nekik sokkal teljesebb életet élni, és lehetővé tesszük, hogy gazdagabbá tegyék maguk körül a világot."

(Mallika Chopra: 100 ígéret gyermekemnek) 


\section{MELLÉKLET}

\section{Az ókori Görögország öröksége}

\section{A görög föld múltja}

Az ókori görög törzsek a Balkán-félszigetre vándoroltak.

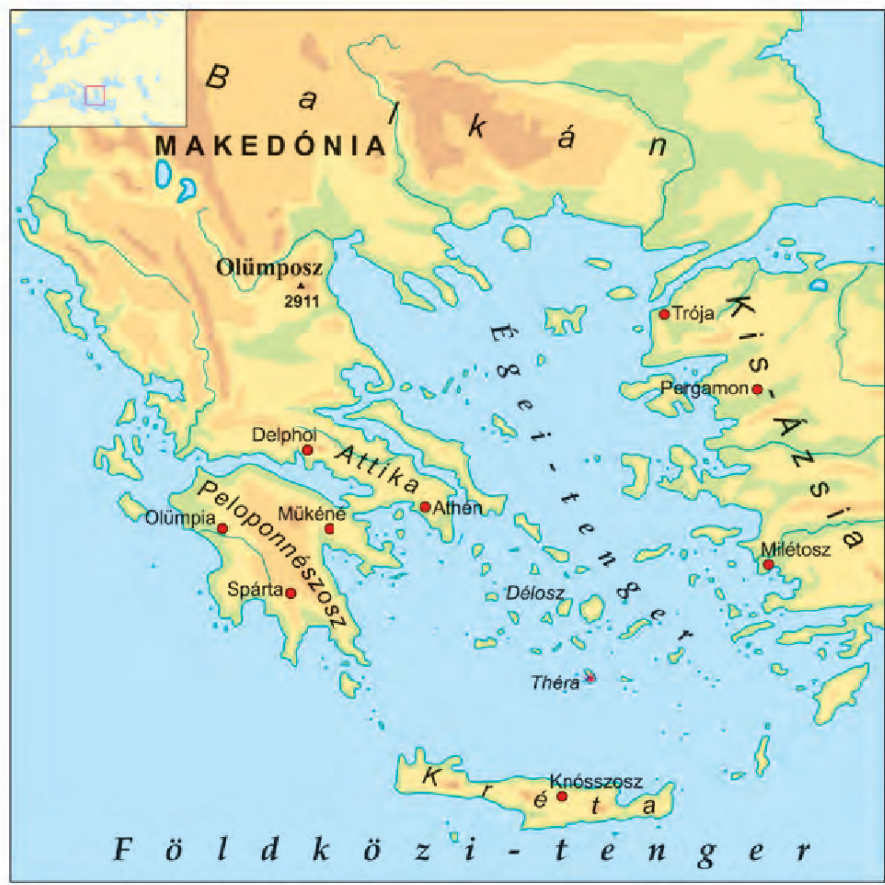

A múltat az épületek romjai, és a mítoszok is őrzik.

A mítoszok istenekről, különös képességekkel rendelkező hősökről szólnak. A mítoszok fontos történelmi források. 


\section{A trójai háború története}

Az istenek lakodalmat tartottak.

Minden isten és istennő meg volt hívva.

A veszekedés istennőjét nem hívták meg.

A veszekedés istennője megharagudott.

Egy almát gurított a mulatozó nép közé.

Az alma aranyból volt.

Az almára azt a szót írta,

hogy a legszebbnek.

3 istennő összeveszett az almán.

A főisten tanácsára Trója királyának kellett igazságot tenni.

A főistent Zeusznak hívták.

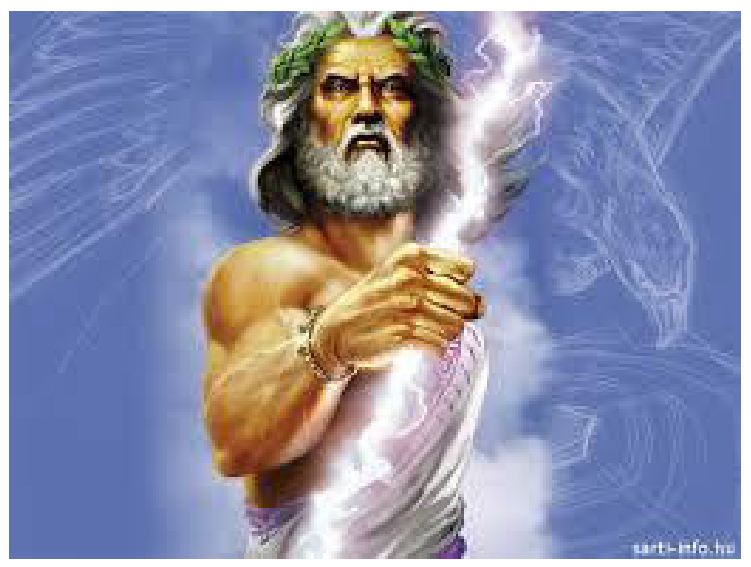

A 3 istennő ajándékot akart adni az almáért a királynak.

Az egyik istennő hatalmat ígért.

A másik istennő bölcsességet ígért.

A harmadik istennő a legszebb nő szerelmét ígérte. 
A király a legszebb nő szerelmét választotta.

A legszebb nő azonban a spártai király felesége volt. A szerelem istennője segített Trójába szöktetni a nőt.

A spártai király nagyon haragudott, ezért megtámadta Tróját.

\section{A trójai faló mondája}

A trójai háború 10 évig tartott, egyik fél sem tudott győzni.

A görög király,

Odüsszeusz cselt eszelt ki.

Azt találta ki,

hogy építsenek egy nagy falovat.

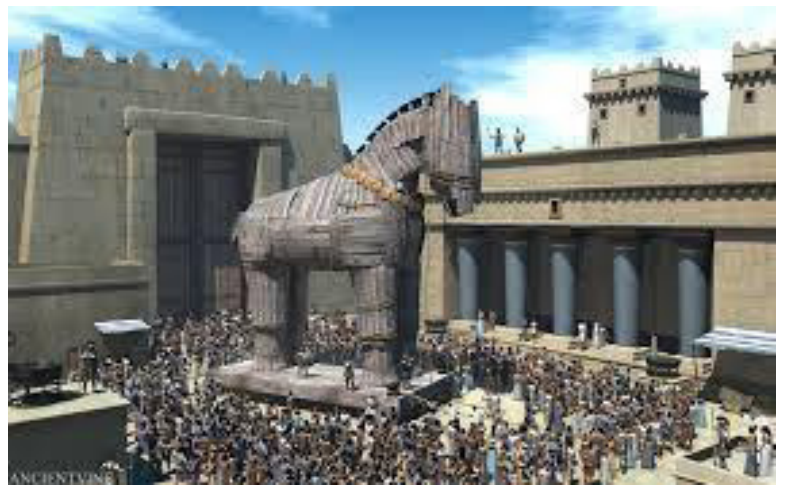

A faló belsejébe elbújtak a legügyesebb katonák.

A többi katona hajóval elment.

A trójaiak bevonták a falovat a várba.

Éjszaka a katonák előbújtak a falóból.

Beengedték a várba a visszajött görög katonákat.

Ezzel a csellel nyerték meg a görögök a harcot. 


\section{A görögök vallása}

Az ókori görögök több istenben hittek.

Tizenkét fontos görög isten volt.

$\mathrm{Az}$ istenek az Olümposz hegy csúcsán laktak.

Minden istennek feladata volt.

A föisten Zeusz volt.

Zeusz volt az istenek királya.

Zeusz volt az istenek és az emberek atyja.

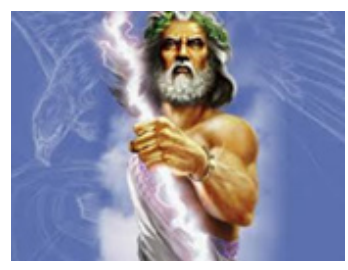

Zeusz testvére Poszeidon.

Poszeidon a tengerek istene.

Az alvilágnak is volt istene.

Az alvilág istenét Hádésznak hívják.

Zeusz lánya Pallasz Athéné.

Pallasz Athéné a bölcsesség

és a művészet istennője.

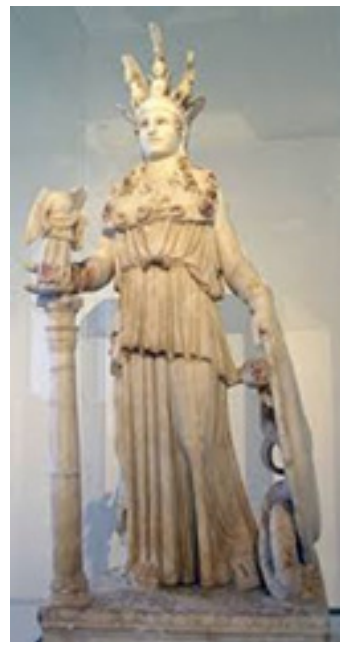

A görög nép fontos kérdésben az istenek tanácsát kérte. 


\section{A dicső Athén}

A görög törzsek egyre nagyobb területen laktak.

Nagyon sok független városállam alakult ki.

Athén és Spárta voltak a legjelentősebb városállamok.

Athén a Balkán félszigeten,

Attikán található.

Athénban olajfaligetet és szőlőt telepítettek.

Athénból sok olajat

és bort szállítottak.

A bort és az olajat

kereskedelmi hajókon

szállították.

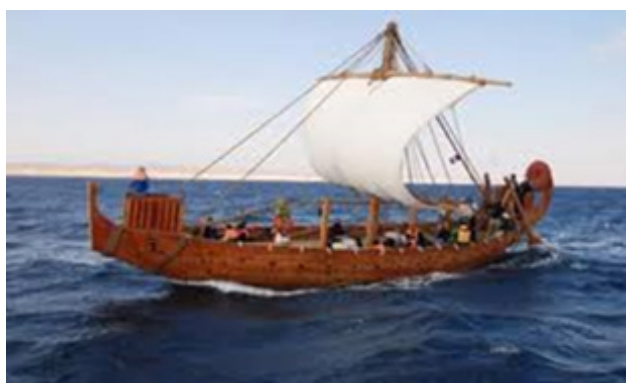

Az athéni iparosok híresek voltak.

Nagyon híres iparosok voltak a fazekasok.

A fazekasok vázákat is készítettek.

A fazekasok edényeket is készítettek.

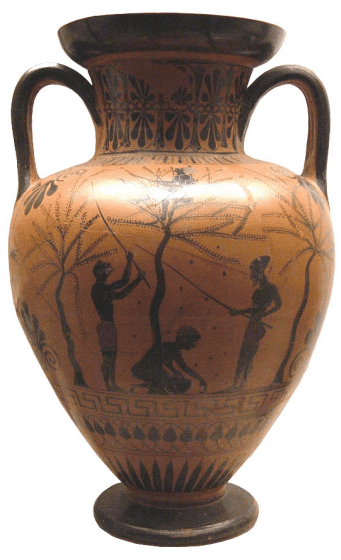




\section{Spárta és a spártai nevelés}

Spártában a szabad polgárok kevesen voltak.

Az őslakók elnyomott emberek voltak.

A hegyvidék lakosai voltak a körüllakók.

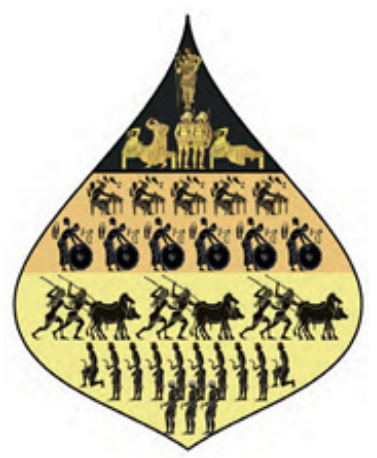

A spártaiak legfontosabb foglalkozása a katonáskodás volt. A katonás életmód szigorú törvények szerint zajlott.

A törvény szerint a szabad spártai családoknak egyformán volt vagyonuk.

Az újszülött fiú gyermeket a város vezetőjének kellett bemutatni. Az erős csecsemő életben maradt.

Felnőttként jó katona lett.

Ha betegesnek tartotta a vezető a csecsemőt, akkor magára hagyták.

A magára hagyott csecsemő meghalt.

A fiúk 6 éves korig éltek a családban. 6 éves koruk után katonai táborban éltek. 20 éves korukban a hadsereg tagjai lettek. 


\section{A görögök összetartozása}

A görög államok egymástól független államok voltak.

Ezeket az államokat városállamoknak nevezzük.

A városállam görög neve polisz.

A görögökben erős volt az összetartozás tudata.

Az összetartozást három dolog erősítette.

Ez a három dolog a közös nyelv,

a közös vallás és a katonai szövetség volt.

\section{Az olimpiai játékok}

Zeusz tiszteletére ügyességi versenyeket rendeztek.

Az olimpiai játékok nagyon híresek voltak.

A győztesek nevét írásokban is feljegyezték.

Az olimpiai játékokat négyévente rendezték meg.

Az olimpiai versenyen minden görög férfi részt vehetett.

A nők még nézőként sem vehettek részt a versenyen.

Az olimpia idején nem lehetett háború.

A verseny első napján ünnepséget rendeztek. 
Az olimpia fő versenyszámai:
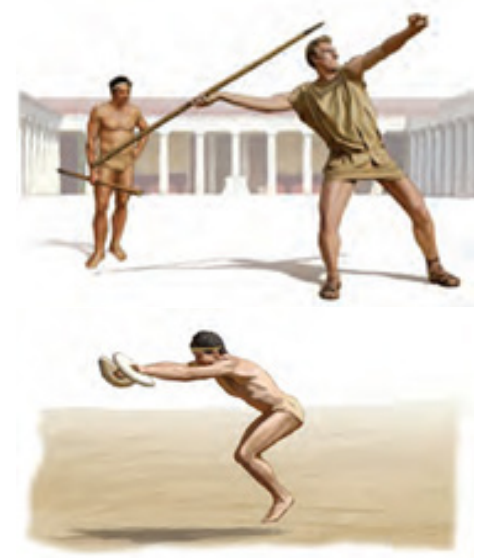

a kocsiverseny,

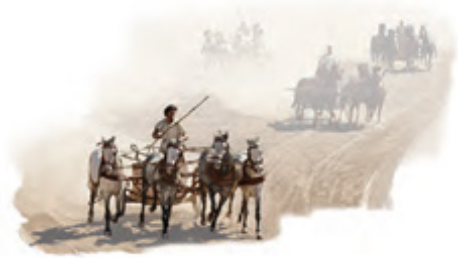

az öttusa,

a futóverseny,
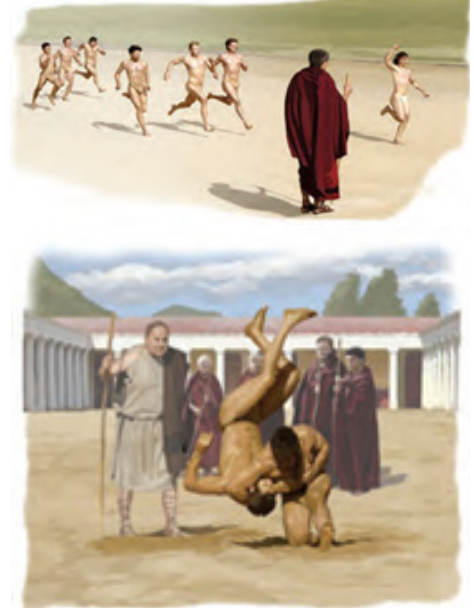

az ökölvívás.

Az olimpiai győztesek jutalma a koszorú volt. A koszorút a szent olajfa ágából fonták.

Az ókori sportjátékokat Olümpiában rendezték meg. 


\section{Könnyen érthető hírek és azok készítése}

\begin{abstract}
A tanulmányban - szemle jelleggel - nemzetközi színtérröl gyűjtött példákat mutatunk be a könnyen érthető hírkészítésre, illetve ehhez kapcsolódóan ismertetem saját innovációs tevékenységemet, melyet a Vajdaságban valósítottam meg.

A könnyen érthető kommunikáció fogalma és gyakorlata már több évtizede jelen van a nemzetközi színtéren. A tömegtájékoztatáshoz füződő jog áttekintését követően a könnyen érthető hírkészítés lépéseit ismertetem. Bemutatok amerikai, német, svéd, belga és magyar jó gyakorlatokat. Szerbia még nem tartozik az Európai Unióhoz, de egy kezdeményezésnek köszönhetően már a vajdasági magyar területeken is ismerik a könnyen érthető kommunikációt, és az emberek könnyen érthető híreket olvashatnak nap mint nap a világhálón. Bízom abban, hogy a vajdasági innováció mintául szolgálhat olyan hírportálok föszerkesztőinek és újságíróinak, akik fontosnak tartják, hogy a hírek minden emberhez eljuthassanak.

Kulcsszavak: értelmi akadályozottság, könnyen érthető kommunikáció, tömegtájékoztatáshoz füződő jog, könynyen érthető hírek, külföldi jó gyakorlatok, magyarországi és vajdasági innovációk
\end{abstract}

\section{BeVEzető}

A könnyen érthetö kommunikációról először 2018-ban hallottam, amikor Szabadkán részt vettem az „Inkluzív fejlesztő szakpedagógia” szakirányú továbbképzésben. Ezt a továbbképzést a Szegedi Tudományegyetem Juhász Gyula Pedagógusképző Kar Gyógypedagógus-képző Intézete indította. Már a képzés alatt megfogott az, hogy mennyire fontos célja van a könnyen érthető kommunikációnak (KÉK). Tudtam, hogy többé nem engedhetem el ezt a gondolatot. Hazámban, a Vajdaságban is szeretném tovább vinni a hírét, és szeretném megismertetni az emberekkel. Elhatároztam, hogy elöször körülnézek a nagyvilágban: utánanézek annak, hogy külföldön hogyan, milyen formában, milyen mennyiségben jelenítenek meg könnyen érthető tartalmakat. Vajon milyen innovációk léteznek? Van-e olyan innováció, amit én is meg tudnék valósítani a környezetemben?

Nagyszerủ külföldi mintákat találtam. Külföldön szinte mindenféle tartalom megtalálható könnyen érthető formában. Németországban, Svédországban vagy Amerikában sok jó példát találtam arra, hogy az információhoz való jogot hogyan lehet például a hírekhez való hozzáférés területén biztosítani.

A sok vonzó példával való megismerkedés után megfogalmazódott bennem, hogy Szabadkán is szükség lenne egy könnyen érthető hírportál bevezetésére. Ez a szabadkai székhelyű, magyar nyelvü Pannon RTV-ben tűnt megvalósíthatónak.

A szerkesztőség engedélyezte, hogy az általuk megírt aktuális híreket átírjam könnyen érthető hírekké. Ezeket a híreket meg is osztották a hivatalos weboldalukon. Így valóban mindenkihez eljuthattak a vajdasági KÉK-hírek. Nagy öröm, hogy a kezdeményezés tartós projektté vált. Idén januárban a Pannon RTV weboldalán a KÉK-hírek 2 éves lett.

Tanulmányomban a külföldi jó gyakorlatokat és saját innovációmat fogom bemutatni. Azt remélem, hogy még több emberben tudatosul: a könnyen érthető üzenetek készítése hittel teli, komoly elhivatottság és feladat. 


\section{AZ INFORMÁCIÓHOZ, AZON BELÜL A TÖMEGTÁJÉKOZTATÁSHOZ FÚZŐDŐ JOG}

A Fogyatékossággal élő személyek jogairól szóló ENSZ egyezmény a 9. cikkében a hozzáférhetőséget fogalmazta meg célul. Felszólítja az államokat, hogy tegyék könnyen elérhetővé az információs szolgáltatásokat, dokumentációkat, médiát (tv, rádió, újságok) a fogyatékos emberek számára. A tömegtájékoztatás szereplőinek alkalmazkodniuk kellene az emberek valós szövegértelmezési képességeihez (Csató, 2002). Ez az alapja a teljes körű részvételnek, aktív állampolgári létnek. Így lehetne elhárítani azokat az akadályokat, amelyek eddig megnehezítették az információkhoz való hozzáférést (Farkasné \& Graf-Jaksa, 2009).

A fogyatékosságügyi ENSZ egyezmény 9. cikk d. pontja felhívja a figyelmet arra, hogy mennyire fontos, hogy a fogyatékos emberek, ezen belül az értelmi sérült személyek az interneten is tudjanak informálódni. Ők is tájékozódni szeretnének a nagyvilág híreiről, mint minden más ember. A 21. század embere általában az online felületeken tájékozódik leginkább és leggyakrabban. Fontos a fogyatékosságügyi ENSZ egyezmény hivatkozott cikke, mert külön megszólítja a tömegtájékoztatást nyújtó szolgáltatókat, hogy tegyenek meg mindent annak érdekében, hogy a tömegtájékoztatás akadálymentes legyen az internetes felületeken is.

\section{A KÖNNYEN ÉRTHETŐ HÍREK KÉSZÍTÉSÉNEK LÉPÉSEI}

Léteznek általános útmutatók arról, hogyan kell könnyen érthető kiadványt készíteni. Így például megtudhatjuk, hogyan kell a könnyen érthető kiadvány célját és tartalmát meghatározni. Fontos elv a könnyen érthető üzenet könnyen érthetőségének ellenőriztetése is. Ezeknek az útmutatóknak az ismerete nagy segítséget jelent azok számára, akik először próbálkoznak könnyen érthető kiadványt írni. A szempontok mindenképpen hasznosak, de nem szabad azonban elfelejteni azt sem, hogy a könynyen érthető üzenet készítése egy alkotó folyamat, amelynek során a szabályokat nem kell feltétlenül mereven betartani. A szerkesztők, illusztrátorok, fotósok, és más közremüködők kiteljesíthetik tehetségüket, hozzájárulva ezzel a valóban könnyen érthető információk terjesztéséhez (Csató, 2002).

A könnyen érthető üzenet készítésének általam alkalmazott lépéseit az alábbiakban mutatom be.

\section{A könnyen érthetö hír célja és célcsoportja}

A könnyen érthető információ készítésének elsődleges célja az információ akadálymentesítése.

A könnyen érthető hír céljának meghatározását mérlegelni kell: vajon milyen tartalmú hír érdekelheti a célcsoport tagjait? Ha az olvasó élvezi a könnyen érthető hír olvasását, akkor mondhatjuk azt, hogy a cél megvalósult (Farkasné \& Graf-Jaksa, 2009). 
Fontos tehát azt meghatározni, hogy kinek készül a könnyen érthető hír. A könynyen érthető kommunikáció elsődleges célcsoportját az értelmi sérült emberek alkotják. A másodlagos célcsoport pedig az üzenet megértéséhez más okok miatt támogatást igénylő személyek képezik (Farkasné, 2017).

Fontos, hogy legyen olyan értelmi sérült munkatársunk, aki tapasztalatával segíteni fog akár a témák kiválasztásában, érdekes javaslatok és ötletek felvetésében, valamint a könnyen érthető hír könnyen érthetőségének az ellenőrzésében (Farkasné \& Graf-Jaksa, 2009). Ezt a személyt tapasztalati szakértőnek is nevezhetjük. A könnyen érthető hírek könnyen érthetőségének ellenőrzésével aktív munkát végezhet, a könnyen érthető kommunikáció szakemberévé válhat (Inclusion Europe \& ÉFOÉSZ, 2009).

\section{Az üzenet típusa és tartalma}

Mint minden embernek, úgy az értelmi sérült személyeknek is fontos az, hogy olyan információkhoz jussanak hozzá, amelyek az életük szempontjából fontosak, és amelyek könnyebbé tehetik a mindennapjaikat. Például tájékoztatás a helyi tömegközlekedésről, az orvosnál várható szituációkról, a pénz használatáról vagy a háztartási eszközök alkalmazásáról, a helyi és az országos választásokon való részvételről, a kötelezettségekről és a jogokról (Csató, 2002).

Fontos támogatni a célcsoport általános ismeretszerzését például könnyen érthető hírekkel vagy arról, hogy ott, ahol élnek (ország, város, falu), kitöl és miben kérhetnek segítséget. Például hogyan vehetnek igénybe különböző támogatásokat (családi pótlék, szociális támogatás nagycsaládosoknak, munkanélkülieknek stb.).

A könnyen érthető hírek lehetnek például az aktuális hírek, politikai hírek, gazdasági hírek, jogi hírek, kulturális, vallási, rekreációs programokról szóló hírek, egészségügyi hírek, fogyasztói, vásárlói hírek vagy általános közlekedési hírek.

A könnyen érthető üzenet lehet elsődleges vagy másodlagos szöveg. Az elsődleges könnyen érthető szöveg eredeti, korábban még nem megírt szövegeket jelent. A másodlagos szöveg egy már létező szöveg könnyen érthető nyelvi szintre történő fordítását jelenti (Farkasné, 2017).

A szöveg lehet akár elsődleges, akár másodlagos, a legfontosabb mindig a következetesen, logikusan megírt, egymásra épülö tartalom. A tartalom összeállítását megkönnyítheti az, ha vázlatot készítünk arról, hogy mit szeretnénk szövegbe foglalni.

A tartalom meghatározásánál is egyeztessünk a tapasztalati szakértővel. Ötleteit, észrevételeit, kérdéseit jegyezzük le (Csató, 2002).

\section{A könnyen érthető hír megírásának legfontosabb szempontja}

Használjuk a magyar nyelven elérhető általános útmutatókat.

Talán a legfontosabb, hogy olyan kifejezéseket használjunk, amely a célközönség számára érthető, szókincsüknek valószínűsíthetően része. A cél az, hogy a szöveget minél több ember meg tudja érteni, és hasznát vegye a mindennapi életben. 


\section{A könnyen érthető üzenet érthetőségének ellenőrzése az értelmi sérült személy segítségével}

Amikor készen vagyunk a könnyen érthető hírrel, akkor a tapasztalati szakértő olvassa el és értelmezze azt. A számára nem, vagy nehezen érthetö részeket vele közösen javítsuk. Az elkészült könnyen érthetö hír csak akkor kerülhet a nyilvánosság elé, ha annak érthetőségét a tapasztalati szakértő ellenőrizte. Ne siettessük a munkájában! Érezze azt, hogy van ideje nyugodtan áttanulmányozni, megérteni a szöveg tartalmát. A képek, illusztrációk, szimbólumok esetében is fontos a javítás akkor, ha az ellenőrzést végző személy számára nem világos, vagy nem érthető azok jelentése. $\mathrm{Ha}$ a javaslatok alapján javítottuk a híreket, akkor újra ellenőriztessük a szöveget (Csató, 2002).

A legfontosabb, hogy valóban adjunk a tapasztalati szakértő véleményére. Amit csak lehet, azt úgy javítsunk ki a szövegben, ahogyan azt javasolta. Lehetnek azonban olyan esetek, amikor nem értünk egyet a javaslattal. Például egy intézmény vagy szervezet nevét nem tudjuk leegyszerüsíteni még akkor sem, ha az értelmetlen a tapasztalati szakértő számára. Ilyen esetben meg kell értetnünk a tapasztalati szakértőkkel, hogy ezen nem lehet változtatni, mert ez egy állandó megnevezés. Egy adott intézményt annak a valós elnevezésével kell használnunk, ezt a formát kell alkalmaznunk a könnyen érthető szövegben is (Inclusion Europe \& ÉFOÉSZ, 2009).

Az első ellenőrzést és javítást követően ismét konzultálnunk kell a tapasztalati szakértőnkkel. Újra és újra meg kell kérni őt arra, hogy ellenőrizze a folyamatosan javított kiadványt. Az ellenőrzés és a javítás folyamatának egyfajta körforgásban kell megvalósulnia a könnyen érthető kiadvány szerkesztői és a tapasztalati szakértők között. Amikor minden felvetésre választ adtunk, és a tapasztalati szakértőnek nincs már több javaslata, akkor készült el a szöveg. Kezdődhet a nyomtatás, vagy az online felületen elhelyezhetjük a könnyen érthető hírt (Csató, 2002).

\section{JÓ GYAKORLATOK A KÖNNYEN ÉRTHETŐ TÖMEGTÁJÉKOZTATÁSRA}

Ebben a fejezetben azokat a külföldi hírportálokat mutatom be, amelyeket nap mint nap olvashatnak könnyen érthető hírekre igényt tartó emberek. Remélem, hogy ezekkel inspirálóan hathatok más hírportálok szerkesztőségeire, és így egyre több hírportál válhat akadálymentessé az értelmi sérült személyek számára.

Nagyon hasznos és tanulságos látni, hogy a világ különböző pontjain milyen területeken, milyen módszerekkel alkalmazzák a mindennapi élet megkönnyítésére a könnyen érthető kommunikációt. Érdekes, hogy a könnyen érthető hírek továbbításával külön szervezetek és vállalatok foglalkoznak, amihez bizony csapatmunkára van szükség.

Több ötletet is meríthettem ezekböl. Motiváltabb lettem azzal, hogy láthattam, hogy az információk akadálymentesítésének nincsenek határai. Az ember akaratától és kreativitásától függ minden. A könnyen érthető hírek hidat képezhetnek köztünk és az információ között. 


\section{JÓ GYAKORLAT AZ USA-BAN}

Az Egyesült Államokban például a The Times indított egyszerüen érthető magazint „The Times in Plain Language” elnevezéssel. Ezek a szövegek nem könnyen érthetők, hanem egyszerüen érthetők: itt nem a könnyen érthető kommunikáció tartalmi és formai szabályait követik. Például nem írnak minden mondatot külön sorba, a tartalom sem feltétlenül rövid. Ugyanakkor egyszerü szavakat használnak, ami az egyszerű megértést biztosítja. A szövegek másodlagosak, vagyis az eredeti Times Magazin cikkeit fordítják le egyszerüen érthető nyelvi szintre. A szövegek mellé mindig egyértelmű, a téma értelmezését segítő képet tesznek a szerkesztők. Jól olvasható betűtípust alkalmaznak, kivéve a címeknél. Ezeknél betűtalpas típust használnak, azonban sokkal nagyobb méretben. A méret hozzájárulhat ahhoz, hogy az olvasó el tudja olvasni a címet, és egyben felkeltse az érdeklődést.

A szövegek után vagy a szövegközben olyan elérhetőségeket vagy online linkeket találunk, amelyekre rákattintva az olvasó további egyszerűen érthető információt olvashat a témáról. Nagyon pozitív tapasztalat, hogy az oldalon különböző nyelvek kiválasztására is lehetőség van. Ha magyarul szeretném olvasni a híreket, akkor a magyar nyelvet kell kiválasztanom. Még afrikai nyelvek választására is van lehetöségünk, ezért igen terjedelmes a nyelvválasztás lehetősége. A fordítás automatikusan generálódik, így nem mindig pontos, de úgy gondolom, ez ezzel együtt is nagyon jó kezdeményezés.

Az érdeklődők olvashatnak politikáról, kultúráról, egészségügyről, oktatásról, bevándorlásról, és még sok más aktuális és a világot érintő témáról. Ezzel hozzájárulnak ahhoz, hogy az alacsony nyelvi kompetenciával rendelkező személyek is napi rendszerességgel tájékozódhassanak a világban zajló eseményekröl.

Számomra újdonság volt, és nagyszerü kezdeményezésnek tartom, hogy a tartalmakat a tanárok is tudják hasznosítani az oktató munka során. Az aktuális hírekhez, információkhoz rövid kérdések, mondhatni tudásfelmérők kapcsolódnak. Ezt a tartalmat a „Tippek a tanároknak” menüpontban érhetjük el.

Az oldalon megtalálható minden elérhetőség (e-mail, telefonszám, Facebook, Twitter), amely segítségével kapcsolatba tudnak kerülni az olvasók a magazin szerkesztőivel, valamint kérdéseket tudnak feltenni, továbbá hozzászólásokat, véleményeket tehetnek közzé.

\section{Jó GYAKORLATOK NÉMETORSZÁGBAN}

A német nyelvü online hírközlő felületeken is fantasztikus példákat találhatunk.

Bár nem többségi hírportál, mégis fontosnak tartom bemutatni a Netzwerk Leichte Sprache oldalát. A honlapról számos könnyen érthető kiadványt tölthetünk le. Amikor 2019-ben először felkerestem a weboldalt, valóban kitünő kiadványokat találtam. Lenyügözött a weboldal külalakja, tartalma és az olvasóknak kínált sokszínű lehetőség. Nagy örömömre így van ez most is, 2021-ben. A honlapon elérhető kiadványokban a könnyen érthető kommunikáció fogalmáról, céljáról, az emberek jogairól, különböző szabályokról olvashatunk. Olyan a felhasználók számára ritkán részletezett témákról is tesznek közzé anyagokat, mint a párkapcsolat, a szexuális együttlét, a fogamzásgátlás, tanácsok a várandós nők számára a terhességi idő alatt vagy magáról a szülésről, illetve a nemi hovatartozás kérdéseiről, mint például a leszbikusság. Ezek 
nagyon komoly témák, amelyeket jól és részletesen magyaráznak meg, úgy, hogy az valóban nagyon sok célcsoport számára érthető. A kiadványokon az Inclusion Europe által bevezetett logót használják. Ez azt jelzi, hogy a kiadványok készítésében és ellenőrzésében tapasztalati szakértő is részt vett.

A weboldal a formai követelmények teljesítése tekintetében is példaértékű. A szövegek mellett mindig egyértelmü, látványos kép található. A betűk megfelelő méretűek. A háttér színe is változtatható: lehet fehér és fekete háttérrel is olvasni. Az olvasó választhatja a felolvasó szoftver opciót is. Így az olvasni nem tudó személyek is hallás útján jutnak hozzá az információkhoz.

A tájékoztatást szolgáló különböző internetes címek, telefonszámok mellett olyan szervezetek adatait is elérjük, amelyek további információt szolgáltatnak az olvasónak, vagy amelyeket felkeresve további tanácsokhoz és hírekhez juthatunk.

Ez a weboldal biztosította számomra a legtanulságosabb és legjobb példákat arra, hogy a 21. században hogyan lehet figyelembe venni minél több emberi igényt, és hogyan lehet professzionálisan alkalmazni a könnyen érthető kommunikációt.

Rendkívül fontosnak tartottam bemutatni az oldalt, mert úgy vélem, olyan innovációról beszélhettünk, amelyek átolvasása ötleteket adhat annak, aki a könnyen érthető kommunikációval szeretne foglalkozni, és azoknak is, akik már ismernek és müködtetnek könnyen érthető weboldalakat, de új innovációkra bukkanhatnak ebben a leírásban.

Egy másik német online felület, a Lebenshilfe weboldal. Örömmel tájékozódtam ezen a honlapon, mert a szövegek mellett olyan képeket használnak, amelyek alapján egyértelművé vált számomra, hogy miről van szó a cikkekben. A weboldal nagyon korszerü és igényes. Olyan témákról lehet olvasni, amelyek minden embernek fontosak, és amelyek hozzájárulhatnak a könnyebb életvitelhez és életvezetéshez. Ilyen téma például a család és a családalapítás, a munka és a munkavállalás, a pénz használata, a nők, az idősek vagy a gyerekek élete, velük kapcsolatos információk.

\section{Jó GYAKORLATOK SVÉDORSZÁGBAN}

Megnéztem a svédországi 8sidor hírportált is. Ez egy valódi könnyen érthető hírportál. Munkám szempontjából ez a hírportál volt a legfontosabb és a legérdekesebb, hiszen hasonló célú és tartalmú információkat igyekszem közölni a Vajdaságban.

A 8 SIDOR oldalán napi rendszerességgel jelennek meg könnyen érthető hírek. Sok a jól értelmezhető kép, melyek nagysága, minősége, tartalma teljes mértékben megfelel a követelményeknek. A képeknek felhívó ereje van, és könnyen értelmezhetők. A felolvasó szoftver lehetőségével is élni tud az olvasó; segítségével egy női vagy férfihang hangosan felolvassa a szöveget, miközben szóról szóra haladva kijelölődnek az abban a pillanatban olvasott szavak. Kiválaszthatjuk, hogy a kijelölt olvasott szó milyen színű és hátterü legyen, milyen legyen a felolvasás hangereje. Lehet választani a lassú, normál vagy gyors felolvasási tempók közül. Ezek a lehetőségek elkápráztatók. Azt láttam, hogy egyszerre számos olvasási igényt ki lehet elégíteni, legyen szó akár látássérült emberről, értelmi sérült emberről, vagy olyan személyről, aki nem tud olvasni, de a hírekhez így egyenlő eséllyel tud ő is hozzájutni. A weboldalon számos rovatot múködtetnek: kultúra, sport, politika, gasztronómia vagy aktuális időjárás-jelentések. 
Ez a weboldal azt bizonyította számomra, hogy nincsen lehetetlen a könnyen érthető kommunikációban, és a határokat mindig tágítani lehet. Egy kis kreativitással és ambícióval a médiát minden ember számára elérhetővé, olvashatóvá lehet tenni.

\section{Jó GYAKORLATOK BELGIUMBÓL}

A Belgiumban működő Inclusion Europe weboldala is remek példa a könnyen érthető kommunikáció alkalmazására. A honlap valójában kétnyelvü: a sztenderd nyelv mellett a könnyen érthető kommunikáció európai logójára klikkelve jutunk el a könynyen érthető nyelvi változathoz. A szervezet föleg önérvényesítéssel foglalkozik, így a szavazati jogokról, döntéshozatalról, ezekhez kapcsolódó témákról jelentet meg cikkeket angol nyelven.

A weboldal nagyon fiatalosan, lendületesen felépített. Böven találunk videókat és jól értelmezhető képeket is. Minden szükséges információ, elérhetőség és együttmüködő szervezet neve és elnöke is megtalálható a kapcsolódó tartalmaknál (így a magyarországi ÉFOÉSZ is). A szervezet megtalálható más közösségi oldalakon is (a Facebookon, a Twitteren, van saját csatornája a YouTube-on is).

Az Inclusion Europe tartalmas leírást adott ki 2020 márciusában arról, hogy a koronavírus-járvány milyen hatással volt és van az értelmi sérült emberek életére. Több tagország is csatlakozott a kezdeményezéshez. Ezért összesen 7 nyelven jelent meg a kiadvány (angol, francia, német, spanyol, román, magyar, olasz).

Az Inclusion Europe önérvényesítéssel foglalkozó önálló szervezete az EPSA (European Platform of Self-Advocacy; Önérvényesítők Európai Platformja). Az EPSA könnyen érthető hírlevele az „Európa Nekünk”. A hírlevél külalakjára, átláthatóságára és értelmezhetőségére is nagyon ügyelnek a szerkesztők. A hírlevélben olvashatunk például arról, hogy az Európai Parlament milyen fontos döntéseket hozott a fogyatékos emberek jogaival kapcsolatban, vagy arról, hogy a karantén milyen negatívumokkal vagy pozitívumokkal járt az értelmi sérült emberek számára. Olvashatunk az értelmi sérült emberek oktatási jogairól. Konkrét tapasztalatokat is megosztanak arról, hogy milyen harcokat kellett megvívni, hogy érvényesíteni tudják az oktatáshoz való jogukat. Érdekes írás található a befogadó iskolákról és a befogadó társadalomról. Videókat tekinthetünk meg, amelyek a fogyatékos emberek munkavállalását támogatják. A hírlevelek végén tartalmas szómagyarázat segíti az olvasót. A szómagyarázatban megtalálható az összes olyan kifejezés, amely a hírlevélben megtalálható, és amelyek az értelmi sérült emberek számára vélhetően nehezebben értelmezhetők, vagy éppen idegen kifejezések. Ilyen szavak például a diszkrimináció, az Európai Parlament, a gondnokság, a hozzáférhetőség, az inkluzív oktatás és munka.

\section{Jó GYAKORLATOK MAGYARORSZÁGRÓL}

Magyarországon egyelöre talán kevesebb a lehetőség könnyen érthető üzeneteket olvasására. Ilyen honlap - bár nem hírportál - az ÉFOÉSZ vagy a Down Alapítvány honlapja.

Az ÉFOÉSZ önérvényesítőinek weboldala az Együtt Velünk - Önérvényesítés azonban egyfajta szakmai hírportálként müködik. Az oldalon megtaláljuk az Európai Unió és az Európai Bizottság bemutatását, híreket a szavazati jogról, mint például 
a „Visszakapják a választójogukat a gondnokság alatt álló emberek Németországban!" című cikk. A pénzkezelés témájával is foglalkoznak, amely részletesen bemutatja a bankszámla nyitásának folyamatát, és azt, hogy hogyan kell pénzt felvenni az automatákból.

A tartalmi és formai követelményeknek is megfelelnek a könnyen érthető cikkek. A betük és a címek megfelelö méretűek. A címek után többnyire nagyméretüek a képek, amelyek jól láthatóak, jó minőségűek, és mindig a kulcstémára utalnak. A kulcsszavakat félkövér betütípussal emelik ki. Találunk hivatkozásokat, linkeket, kiadványokat is.

A Down Alapítvány weboldalán a KÉR menüpontban találhatunk több könnyen érthető kiadványt. Olvashatunk illemtani szokásokról, ügyintézésekröl, az emberek jogairól, egészséges életmódról, közlekedési szabályokról, turizmusról. A mostanában az egyik igen aktuális témáról, a COVID-19-ről is fontos tudnivalókat lehet megtalálni.

Farkasné Gönczi Rita honlapja jól szolgálja a könnyen érthető kommunikáció hazai terjesztését. Olvashatunk könnyen érthető receptekről vagy főzési, sütési eljárásokról, a konyhai gépek használatáról, de komolyabb témákat érintő kiadványok is jelen vannak az oldalon. Ilyen a „Fogyatékosság és bántalmazás” című könnyen érthető kiadvány (Borbás B. és mtsai, 2017), a választójogokról szóló kiadvány, vagy a fogyatékosságügyi ENSZ egyezmény. Ezen a weboldalon is olvashatunk a koronavírusról, illetve arról, hogy milyen új szabályokat vezettek be Magyarországon a koronavírus-járvány következtében.

A kiadványok megfelelő betűméretben és betűformázással íródtak, minden könynyen érthető üzenetben megfelelő nagyságú, minőségű és tartalmú kép, illusztráció vagy szimbólum segíti az értelmezést. A „Fogyatékosság és bántalmazás” című kiadványban például lehetősége van az olvasónak kiválasztani 4 könnyen érthető forma közül azt a szintet, amely a legjobban megfelel számára. A négy különböző szintet négy különböző színnel jelölik. Az első, kékkel jelölt szint a hosszú szövegeket jelöli, amely kevesebb képet tartalmaz. A második, pirossal jelölt szint rövid szövegeket tartalmaz, és néhány képpel támogatja a megértést. $A$ harmadik, sárgával jelzett szinten felsorolásokat, listákat lehet olvasni arról, hogy mit kell tenni bántalmazáskor, valamint képeket is használnak. A negyedik, zölddel jelölt szint képsorozatokat tartalmaz a bántalmazás fajtáiról, és arról, hogy hova és kihez lehet fordulni bántalmazás esetén, mit kell tenni, ha bántalmazás történt. A kiadvány végén adatbázist találunk azokról az intézményekről (logóval és elérhetőséggel) amelyek segíteni tudnak bántalmazás esetén.

\section{KÖNNYEN ÉRTHETŐ KOMMUNIKÁCIÓ SZERBIÁBAN}

Tapasztalataim szerint Szerbiában még kevés ember hallott a könnyen érthető kommunikációról. Az ország gyógypedagógiai képzést folytató egyetemein még nem oktatják, nem ismertetik a hallgatókkal ezt a módszert. Nem tudok egyetlen szerb nyelvű könnyen érthető kiadványról vagy szakirodalomról sem. A Vajdaságban a Szegedi Tudományegyetem Juhász Gyula Pedagógusképző Kar Gyógypedagógus-képző Intézete 2018-ban indított először kétéves gyógypedagógiai témájú szak- 
irányú továbbképzést, aminek köszönhetően egyre több vajdasági magyar, illetve szerb anyanyelvű kollégához jut el a könnyen érthetö kommunikáció.

Még mindig igaz, hogy a Vajdaságban inkább magyar nyelven elterjedtebb a könynyen érthető kommunikáció, föként a fiatalság körében. Ennek az is az oka, hogy a magyar ajkú vajdasági fiatal gyógypedagógusok, akik Magyarországon fejezték be egyetemi tanulmányaikat, visszatérésükkor mesélnek a megszerzett ismeretekröl, ideértve a könnyen érthető kommunikációról szerzett tudásukat és gyakorlatukat is.

\section{KÖNNYEN ÉRTHETŐ HÍRPORTÁL LÉTREHOZÁSA A VAJDASÁGBAN}

Munkám során célként tüztem ki azt, hogy a könnyen érthető kommunikáció fogalma ne csak a vajdasági magyar nyelvü gyógypedagógusok és értelmiségiek körében tudatosuljon, hanem a hétköznapi vajdasági ember is találkozhasson vele. Így az emberek egy része talán már nem lepődik meg egy-egy KÉK-hír láttán, és nem háborodnak fel azon, hogy minek kell ilyen „ovis” szinten megírni egy hírt (saját tapasztalat, a KÉK-hírekhez írt kommentek alapján használom ezt a kifejezést).

De kezdjük az elejéröl. Amikor 2019-ben meg kellett írnom a szakirányú továbbképzés végén a szakdolgozatomat, úgy döntöttem, hogy a könnyen érthető kommunikáció lesz a témám. Tudtam, hogy Magyarországon már kiváló minták léteznek. Elhatároztam, hogy megismertetem a vajdasági emberekkel is azt, hogy mit jelent a könnyen érthető kommunikáció, és miért olyan fontos. Az akkori témavezető tanárommal, dr. Horváth Péter Lászlóval megbeszéltem, hogy meglátogatom a szabadkai Pannon RTV-t, azért hogy beszélgetni tudjak a föszerkesztőjével. A cél az volt, hogy megszerezzem a támogatását könnyen érthető másodlagos hírek közzétételéhez az online hírportál oldalán. A szerkesztőség, később az igazgatóság is nagyon pozitívan és nyitottan állt az ötlethez, ezért igent mondtak a projektre. 2019. január 24-én megkezdődött az együttműködés a PannonRTV-vel.

Egy héten többször ellátogattam a médiaházba, annak érdekében, hogy akár több riporterrel és szerkesztővel együtt írhassak könnyen érthető híreket. Fontosnak tartottam, hogy minél több médiában dolgozó ember ismerje meg a könnyen érthető kommunikáció fogalmát, fontosságát és módszertanát. Meséltem nekik egy-két külföldi jó gyakorlatról. Elmagyaráztam a formai és tartalmi szabályokat, mutattam könynyen érthető tartalmakat és példákat. A hírek kiválasztása és megfogalmazása előtt minden munkatársnak elmagyaráztam, hogy miről van szó, és mire számíthatnak a munka során. Folyamatosan készítettem a KÉK-híreket. Az elkészült hírek között volt politika, kultúra, sport, oktatás, egészségügy és még sorolhatnám. A Pannon RTV épületébe öt héten keresztül jártam be, amely időszak alatt több riporterrel is volt szerencsém közös munkában részt venni. Láthattam, hallhattam, tapasztalhattam több különböző véleményt a könnyen érthető kommunikációval kapcsolatban. Voltak, akik lelkesen dolgoztak, azonnal átérezték a könnyen érthető hírek létjogosultságát, de voltak olyan újságírók is, akik láthatóan nem szerették volna ezen az új területen kipróbálni magukat. Ilyenkor fontosnak tartottam a közös beszélgetést. Arra jöttem rá, hogy nagyon sok embernek téves információja van az értelmi sérült emberekröl, ezért negatív attitűd alakult ki bennük. Abban azonban mindenki egyetértett, hogy az információkhoz, a tájékozódáshoz minden embernek joga van, és nekünk, akik a híreket alkotjuk, kell erre megteremteni a lehetőségeket. 
Külön örömöt okozott, hogy a Pannon RTV vezetősége komoly igényt látott a hírek kiadására, és így a szakdolgozat megvédését követően felkért a KÉK-hírek írásának folytatására. Így ma már otthonról, önállóan végzem a szövegek írását. Napi 2-4 anyag kerül ki a weboldalra, ahol külön rovatot kaptak a könnyen érhető hírek.

Az elmúlt két évben sok pozitív élményben volt részem a könnyen érhető hírek írása alatt, illetve nagyon sok pozitív visszajelzés is érkezett a Pannon RTV-be és személyem irányába is. Természetesen a mai napig vannak olyan emberek, akik nem értik, hogy mi is a könnyen érthető kommunikáció lényege, és ezt szóvá is teszik akár a könnyen érhető hírek alatt. Sokszor gúnyos hozzászólásokat írnak a facebook. com/pannonrtv oldalán is. Mégis úgy gondolom, hogy a negatív kritikák közül az inkább építő jellegüek segítik a további innovációk létrejöttét. Ennek kapcsán kezdtem el gondolkodni annak megelőzésén, hogy tájékozatlan emberek minden egyes hír alatt elkezdjék kritizálni nem is magát a hír tartalmát, hanem egyszerűen a KÉK-hírek megnevezést (sokan a KÉK szót ugyanis a bünügyi hírekkel azonosították).

Ekkor született meg az ötlet, hogy minden könnyen érthető hír alá két kulcsmondatot helyezzünk el link formájában arról, hogy mit jelent a KÉK, illetve, hogy kik tartoznak az elsődleges célcsoportba. Ha erre a linkre rákattint az olvasó, akkor a KÉK-hírek rovatában találja magát, ahol már részletes leírást olvashat a könnyen érhető kommunikációról. Talán ennek a fejlesztésnek a hatásaként ma már sokkal kevesebb ember támadja a KÉK-híreket, és csak elvétve találunk pejoratív kommenteket a hírek alatt.

Egy másik nagyszerü fejlesztés és élmény volt számomra, amikor 2019-ben egy magyarországi pályázaton vehettem részt, melynek keretében egy rövidfilmet kellett készíteni. Témájaként természetesen a KÉK-et, a KÉK-híreket, valamint a Pannon RTV-vel való közös innovációt választottam. Ezzel az innovációval elnyertem a közönségdíjat. A pályázaton való részvétel és a film egri bemutatása azért is volt számomra nagyon fontos és meghatározó, mert az egész Kárpát-medencéből érkeztek magyar ajkú fiatalok és felnőttek. A zsüriben olyan jelentős eredményeket elért újságírók voltak, akik tanácsaikkal és észrevételeikkel hozzájárultak szakmai fejlődésemhez. Megerősítettek abban, hogy a KÉK-hírekre szükség van, nemcsak a Vajdaságban, hanem minden olyan területen, ahol értelmi sérült emberek élnek. A kisfilmem felkerült a Pannon RTV weboldalára is. Az sem volt kérdés számomra, hogy a filmről és a pályázati részvételről megírjam a KÉK-hírt, aminek szintén nagy olvasottsága volt, és igen nagy örömömre sokan osztották meg a közösségi felületeken is.

Nagy örömömre szolgál, hogy a 2 év alatt több alkalommal is elöfordult, hogy egy-egy könnyen érthető hír volt a weboldal legolvasottabb híre. Ilyen volt például, amikor 2020 májusában egy KÉK-hír bekerült az év első 10 legolvasottabb hírei közé, (106168 ember olvasta el pár nap alatt a koronavírus idején az oktatással foglalkozó hírt). Amikor most, 2021. február elején írom ezt a tanulmányt, az egyik könnyen érthető cikk az első a legnépszerübb cikkek listáján.

Ezek a visszacsatolások, és a sok értelmi sérült gyermek, fiatal és szüleik pozitív visszajelzése adja az erőt a munkához. Vinni kell a hírét minél messzebbre, hogy akár a határokon kívül, például Szerbiában élő magyarok is tudjanak róla, hogy a média lehet mindenkié, és nem szabad falakat építeni egyetlen ember és a tömegtájékoztatás elé sem. 
2020 éppen a koronavírus-járvány miatt sok új kihívást állított elénk, ami egyben még több könnyen érthető hír megírásának lehetőségét eredményezte. Fontosnak tartottam, hogy minden új szabályról, minden új óvintézkedésröl, illetve magáról a koronavírus fogalmáról tájékoztatást adjak az értelmi sérült embereknek.

Szerbiában több mint fél évig távoktatás zajlott, és sok interjút hallhattunk, láthattunk arról, hogy a többségi iskolákban hogyan élték meg ezt az új tanítási módszert a gyerekek, a szülök, illetve a tanárok. Ennek mintájára kerestem fel a Pannon RTV szerkesztőjét, hogy mi lenne, ha Szabadkán is készítenénk egy rövid interjút arról, hogy a fogyatékos gyermekek és tanáraik hogyan tudtak alkalmazkodni a távoktatás kihivásaihoz, és hogy ők hogyan élték meg például a kijárási tilalmakat. Ahogy már említettem, a Pannon RTV szerkesztőségének csapata igen nyitott és pozitív emberekből áll, ezért rögtön igent mondtak az ötletemre. Arra azonban nem számítottam, hogy azt fogják kérni, hogy én magam állítsam össze, készítsem el, és írjam meg az interjúkat. Nagy büszkeséggel tölt el, hogy sikeresen elkészült két interjú, ami szintén felkerült a Pannon RTV weboldalára. Erről a munkáról az eredeti hírt és az elsődleges könnyen érhető hírt is én készíthettem el.

2020 novemberében egy újabb együttmüködésre nyílt lehetőség. Egy Magyarországon élő olyan személy keresett meg, aki szintén sokat foglalkozik a könnyen érthető kommunikációval, emellett önérvényesítő is. Látta a könnyen érhető kisfilmem. Ezért felkeresett azzal a kéréssel, hogy írjak egy könnyen érhető hírt a Magyar Speciális Független Filmszemle programjáról, és legyen ez a vajdasági emberek számára is nyilvános. Így jutott el ennek a fontos kezdeményezésnek a híre (és talán a lehetősége is) a vajdasági emberekhez.

\section{ÖSSZEFOGLALÁS}

Ezek az emlékek és eredmények nagy motivációt adnak a munkám további folytatásához. Még nagyobb öröm, hogy számomra ez nem is jelent munkát, hanem szeretett hobbimként élem meg. Ehhez a szabadságérzethez a Pannon RTV rugalmassága és bizalma is hozzájárul: valóban akkor, annyit és azt a tartalmú KÉK-hírt írhatom meg napi szintem, ami nekem jólesik. Az elmúlt két évben több mint 1500 KÉK-hír megírásával és megosztásával tudtam egy élhetőbb és érthetőbb világ megteremtéséhez hozzájárulni.

\section{Irodalom}

a Fogyatékossággal élő személyek jogairól szóló ENSZ egyezmény, 2006

Borbás B., Farkasné Gönczi R. \& Rajnai E. (2017). Fogyatékosság és bántalmazás. FSZK, Budapest.

Csató Zs. (szerk.) (2002). Egyszerủen, érthetően: útmutató könnyen érthető tájékoztatók készítéséhez. ÉFOÉSZ, Budapest.

Farkasné Gönczi R. (2017). Fogalom. http://konnyenertheto.gonczirita.hu/ismeret/fogalom/ Letöltés ideje: 2021.02.08.

Farkasné Gönczi R. \& Graf-Jaksa É. (2009). Könnyen érthető kommunikáció. In Pandula A., Szatmári P., Vincze T., Farkasné Gönczi R. \& Graf-Jaksa É. (szerk.), Kommunikációs és információs technológiák és fogyatékosságügy. ELTE Bárczi Gusztáv Gyógypedagógiai Kar, Budapest. 80-100.

Inclusion Europe \& ÉFOÉSZ (2009). Információt mindenkinek! A könnyen érthető kommunikáció európai alapelvei. Inclusion Europe - ÉFOÉSZ, Brüsszel - Budapest. 
Példa a KÉK hírre:

Ma van Szent Száva ünnepnapja Szerbiában.

Ma január 27-e, szerda van.

Szent Száva a szerb oktatás

és a szerb kultúra védőszentje.

Az oktatás tanítást jelent.

Sok szerb ember ortodox vallású.

Az ortodox is a keresztény valláshoz tartozik.

Szent Száva volt az önálló szerb ortodox egyház megalapítója.

Szent Száva volt az 1. szerb érsek.

Az érsek szó egyházi főpapot, vagyis püspököt jelent.

Szent Száva író, fordító

és iskolaalapító is volt.

Január 27-e, vagyis Szent Száva napja

1840-ben lett iskolai ünnepnap Szerbiában.

Az 1840-es év 181 évvel ezelőtt volt.

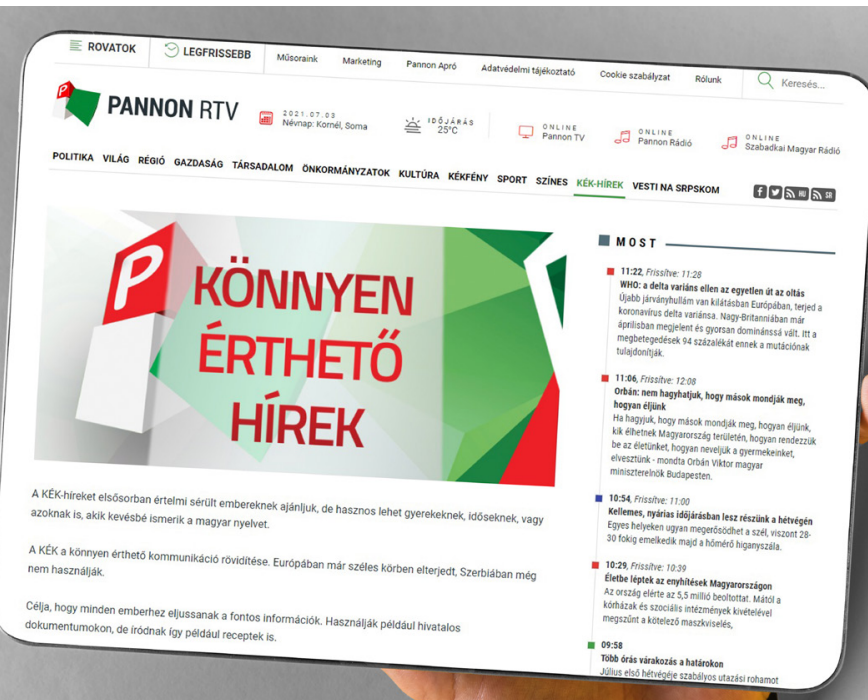




\title{
Az ÉFOÉSZ és tagszervezeteinek törekvései a könnyen érthető kommunikáció területén
}

\begin{abstract}
A tanulmányban - szemle jelleggel - az ÉFOÉSZ és három tagszervezete innovációs törekvéseinek a bemutatására kerül sor. Célom annak bemutatása, hogy mi történt az elmúlt évtizedekben a könnyen érthető kommunikáció területén, illetve milyen tényezők segítik és akadályozzák a módszer hazai elterjesztését. Kitérünk a jövőre vonatkozó tervekre is.

Kulcsszavak: könnyen érthető kommunikáció, innováció, Értelmi Fogyatékossággal Élők és Segítőik Országos Érdekvédelmi Szövetsége (ÉFOÉSZ)
\end{abstract}

\section{BeVEZető}

A világon minden embernek joga van ahhoz, hogy a társadalom aktív tagja legyen. Ez a jog magában foglalja az információhoz való hozzáférés jogát is, legyen szó bármely területröl: irodalomról, kultúráról vagy akár politikáról. Fontos, hogy megfelelő minőségü és mennyiségű információt birtokoljunk egy adott témával kapcsolatban. Ennek érdekében az emberek számára az információt érthető formában kell felkínálni. Így tudnak adekvát döntéseket hozni és a társadalom aktív tagjává válni (Farkasné \& Graf-Jaksa, 2009).

A könnyen érthető kommunikáció (KÉK) egy olyan kommunikációs forma, amely nem csak az értelmi sérült emberek életét könnyíti meg. Gondoljunk a mindennapi életre: nap mint nap találkozunk olyan helyzetekkel, ahol jól jönne, ha valaki elmondaná röviden és érthetően, hogy miről van szó. llyen eset például, ha hivatalos ügyeket szeretnénk intézni. Gyakran olyan bonyolult módon megfogalmazott dokumentumokkal találkozhatunk, amelyeket átlagos nyelvhasználóként is nehéz megérteni.

Képzeljük el az ügyintézést például egy idegen nyelvű országban. Vajdasági magyarként megtapasztaltam, hogy az érthető kommunikáció valamennyiünk életét megkönnyítheti. Nekem a magyar nyelv az anyanyelvem, de az ügyeket szerb nyelven kell intéznem. Szükség van tehát arra, hogy a könnyen érthető kommunikáció módszere ismertté váljon.

Tekintettel arra, hogy a Fogyatékosság és Társadalom című folyóirat jelen tematikus száma a könnyen érthető kommunikációval foglalkozik, a tanulmányban nem térek ki a fogalom meghatározására, a könnyen érthető kommunikációval kapcsolatos elméleti ismeretek összefoglalására.

Magyarországon az Értelmi Fogyatékossággal Élők és Segítőik Országos Érdekvédelmi Szövetsége játszott úttörő szerepet a könnyen érthető kommunikáció elterjesztésében (Farkasné Gönczi \& Graf-Jaksa, 2009). Ezért döntöttem úgy, hogy ezen civil szervezet munkásságát mutatom be ebben a cikkben. A továbbiakban röviden bemutatom az Értelmi Fogyatékossággal Élők és Segítőik Országos Érdekvédelmi 
Szövetségét, a bemutatásra választott civil szervezetet. Ezt követően szeretnék megrajzolni egy térképet, amelyen igyekszem láthatóvá tenni az ÉFOÉSZ és néhány tagszervezetének a könnyen érthető kommunikáció területén végzett munkásságát. A térkép megrajzolásához szükséges információk összegyüjtése érdekében interjút készítettem az alábbi személyekkel, akik hozzájárultak a név közléséhez:

1. az ÉFOÉSZ központi irodájából

a) Bercse László önérvényesítő, az ÉFOÉSZ társelnöke,

b) Czakó Tibor szakmai referens,

c) Sallai Ilona önérvényesítö, érdekvédelmi tanácsadó,

2. Bács-Kiskun megyéből Melcher Györgyné, a megyei szervezet elnöke,

3. Békés megyéböl Schriffertné Locskai Henriett, a megyei szervezet elnöke,

4. Csongrád-Csanád megyéböl Jenei Klára, a megyei szervezet elnöke,

5. Komárom-Esztergom megyéből Szegedi Erika, a megyei szervezet elnöke.

\section{Az ÉRTELMI FogYATÉKOSSÁGgAL ÉLŐK ÉS SEGÍTŐIK ORSZÁGOS ÉRDEKVÉDELMI SZÖVETSÉGÉRŐL}

Az alábbi összefoglalást a szövetség honlapján található információk alapján készítettem.

Az Értelmi Fogyatékossággal Élők és Segítőik Országos Érdekvédelmi Szövetsége (továbbiakban: ÉFOÉSZ) 1981-ben alakult meg, szülői kezdeményezésre. Az elmúlt 40 év alatt országos lefedettségűvé vált, az értelmi sérült személyek érdekvédelmével foglalkozó szervezetek közül egyedüliként. Az ÉFOÉSZ országszerte jelenleg több mint 22 ezer egyéni, és nagyjából 100 jogi személy tagból áll.

Az ÉFOÉSZ célcsoportjai:

1. értelmi sérült személyek,

2. az értelmi sérült személyek családtagjai,

3. az értelmi sérült személyekkel foglalkozó szakemberek,

4. magánszemélyek, akik elfogadják a szövetség céljait.

5. az ügy iránt elkötelezett cégek és vállalatok.

Az ÉFOÉSZ küldetése, hogy a Magyarország területén élő értelmi sérült emberek és családtagjaik társadalmi hátrányait mérsékelje. Emellett fontos, hogy a célcsoportok érdekeit érvényesíteni, képviselni és védeni tudják. Kiemelt cél, hogy az értelmi sérült emberek élni tudjanak emberi és állampolgári jogaikkal, valamint a társadalmi integrációjuk sikeres, szociális biztonságuk és rehabilitációjuk biztosított legyen.

Az ÉFOÉSZ a Fogyatékossággal élő személyek jogairól szóló ENSZ egyezményben, valamint a Madridi Nyilatkozatban foglaltak megvalósításával elő kívánja segíteni az értelmi sérült emberek önrendelkezését, az önmagukért érzett felelősség egyidejü kialakítása mellett. Az ÉFOÉSZ összefogja az értelmi sérült emberek hazai szervezeteit, összehangolja ezen szervezetek tevékenységeit. Arra törekszenek, hogy elismertessék a szövetséget a kormányzati és parlamenti erőkkel, önkormányzati testületekkel (fogyatékosságügyi ENSZ egyezmény, 2006; Madridi Nyilatkozat, 2003). 
A szövetség központi, budapesti irodája - többek között - információk gyűjtésével és továbbításával, különböző kiadványok készítésével (kiemelt szerepet kapnak a könnyen érthető kiadványok), az elnökségi ülések elökészítésével és végrehajtásával, valamint a küldöttgyűlés elökészítésével és végrehajtásával foglalkozik.

\section{A KÖNNYEN ÉRTHETŐ KOMMUNIKÁCIÓ ÉS AZ ÉFOÉSZ}

Magyarországon az ÉFOÉSZ 2002-ben kezdett el foglalkozni a könnyen érthető kommunikációval. Ez nagyjából egybeesik az önérvényesítő mozgalom hazai kialakulásával is.

Ebben az időszakban magyarországi rendezvényeken is elkezdték használni a könnyen érthető segédanyagokat. Így például a konferenciák programját megfogalmazták könnyen érthetően. Kártyákat osztottak ki a résztvevők számára. Ezek három színből állnak - zöld, sárga és piros. A kártyák azt a célt szolgálják, hogy a használója jelezni tudja az előadások közben, ha túl gyors a tempó (sárga), illetve, ha valamit nem ért (piros), vagy ha valamivel egyetért (zöld).

Az ÉFOÉSZ egyre több könnyen érthető kiadványt adott ki. Az Inclusion Europe engedélyével több anyagot is magyarra fordítottak. A Szociális és Munkaügyi Minisztérium támogatásával elkészült az Országos Fogyatékosügyi Program és a fogyatékosságügyi ENSZ egyezmény könnyen érthető változata is. Annak érdekében, hogy az egyezmény bonyolult jogi szövegét az értelmi sérült emberek is megértsék, az ÉFOÉSZ elkészített egy munkafüzetet is, amelyben játékos és a szövegfeldolgozást segítő feladatokkal hozzák közelebb a szöveget az értelmi sérült személyekhez.

Ezt követően az ÉFOÉSZ-t több közintézmény, civil szervezet is megkereste azzal, hogy nyújtson nekik támogatást a honlapjuk akadálymentesítési koncepciójának kidolgozásával (Farkasné \& Graf-Jaksa, 2009).

A továbbiakban az ÉFOÉSZ munkatársaival készített interjúk tartalmát - a könynyen érthető kommunikáció magyarországi felhasználásának elterjesztéséhez kapcsolódó legfontosabb kérdések köré szerkesztve - ismertetem.

\section{A KÖNNYEN ÉRTHETŐ KOMMUNIKÁCIÓ HAZAI ELTERJESZTÉSE ÉRDEKÉBEN VÉGZETT TEVÉKENYSÉGEKRŐL}

\section{Milyen céljai vannak az ÉFOÉSZ-nak a könnyen érthető kommunikáció hazai elterjesztése érdekében? Mit tesznek a kitüzött célok elérése érdekében? Milyen akadályok kor- látozzák a célok elérését?}

Az ÉFOÉSZ-nak az a célja, hogy az értelmi sérült emberek számukra érthető információkhoz jussanak. Ez kell ahhoz, hogy önálló életet tudjanak élni, önálló döntéseket tudjanak hozni, és felelős felnőtt emberként tudjanak élni. A mi célunk az, hogy ezt 
a módszert minél több emberrel megismertessük, föleg azokkal, akik a célcsoporttal bármilyen formában érintkeznek (szakemberek, segítők, szülők). Ez szükséges ahhoz, hogy jól tudják segíteni az általuk támogatott személyeket. A törvények és rendeletek segíthetnek abban, hogy garanciákat kapjunk, vagy érvényesíteni tudjuk a jogokat. A fogyatékosságügyi ENSZ egyezményben van egy cikk, ami a hozzáférhetőségről szól. Ott nevesítve van a könnyen érthető kommunikáció. A magyar jogszabályokban azonban még kevés helyen találkozhatunk a könnyen érthető kommunikációval mint módszerrel. A könnyen érthető kommunikáció kizárólag az Országos Fogyatékosságügyi Programban szerepel, ez utóbbit határozatként, azaz egyedi aktusként fogadta el az Országgyülés. Egyébként nincsen a könnyen érthető kommunikációról külön jogszabály. Ha összehasonlítjuk az értelmi fogyatékos személyek helyzetét például a siket személyek helyzetével, nekik van saját jelnyelvi törvényük. Jó lenne, ha lenne a könnyen érthető kommunikációról szóló törvény is, ahogy más országokban (például Németországban vagy Ausztriában). Ez tehát nagyon nagy akadálynak számít (Czakó Tibor).

Sallai Ilona hozzátette, hogy ők értelmi sérült személyekként sokszor kirekesztődnek a világból, mert nem értik meg azokat az információkat, amelyeket nekik szánnak. Ez azért történik, mert általában szakszavakkal vagy bonyolultan, hosszú mondatokban fogalmaznak. Azért tartja jó módszernek a könnyen érthető kommunikációt, mert az segít nekik az információk könnyebb megértésében. Kiemelte, hogy a szöveget nem lebutítva szeretnék megkapni, hanem a lényeget kiemelve, de mégis az ő képességeikhez igazítva. Az akadályok között Sallai llona is említette azt, hogy hiába csatlakozott Magyarország a fent említett ENSZ egyezményhez, valójában az emberek inkább a fizikai akadálymentesítés fogalmát ismerik, kevésbé az infokommunikációs akadálymentesítését. Megerősítette, hogy szeretnék elérni, hogy minél hamarabb legyen jogszabály a könnyen érthető kommunikációról.

Bercse László kiemelte, hogy például Németországban vannak könnyen érthető blogok; ezeket maguk az önérvényesítők szerkesztik, illetve vannak újságok is, amelyeket lefordítanak könnyen érthető nyelvi szintre. Szeretné elérni, hogy Magyarországon is legyen erre lehetőség.

Jenei Klára szerint a Csongrád-Csanád megyei szervezet célja, hogy az értelmi sérült személyekhez és minél több érintett családhoz eljussanak. Vannak olyan családok, akik nincsenek a látókörükben. Emellett céljuk, hogy a különböző szociális intézményekben dolgozók is megismerjék a könnyen érthető kommunikációt. Véleménye szerint a társadalmi tudatformálásnak jó eszköze a könnyen érthető kommunikáció. El szeretnének jutni továbbá civil szervezetekhez, különböző, például egészségügyi intézményekhez, általános és középfokú iskolákba. Jenei Klára az akadályok között első helyen az ismeretlentől való félelmet említette. Az a tapasztalata, hogy sok esetben zárkózottak az emberek. Így nehéz bármilyen tanfolyamot, műhelymunkát vagy akár önérvényesítőkkel közös beszélgetést szervezni. Sok esetben az értelmi sérült személyek akadályokba ütköznek például vásárlás során, hiszen nehezebben megy nekik a pénzkezelés. A könnyen érthető kommunikációra, a könnyebb nyelvezetủ beszédre az ott dolgozók nem minden esetben nyitottak. Pedig ez megkönnyítené az értelmi sérült emberek életét.

Schriffertné Locskai Henriett elmondta, hogy számukra Békés megyében az az elsődleges cél, hogy minél több ember meg tudja ismerni a környező világot, el tudják látni napi feladataikat. Az ÉFOÉSZ munkatársai pedig próbálnak segíteni 
nekik az eligazodásban, tájékozódásban, és abban, hogy a mindennapjaikat minél önállóbban tudják élni. Ebben nagy szerepe van a könnyen érthető kommunikációnak. Amikor az akadályokról kérdeztem, válasza az volt, hogy meg kell keresniük és tanulniuk azokat az utakat, amelyekkel elérik a céljaikat. Ezt azonban kihívásnak és nem kifejezetten akadálynak fogják fel. Valójában először nekik is fel kell térképezniük azt, hogy milyen tudásra van szükség a könnyen érthető kommunikációhoz, amit aztán tovább tudnak adni.

Melcher Györgyné szerint fontos az, hogy az értelmi sérült emberek számára akadálymentes környezetet alakítsanak ki. Ök ugyanolyan emberek, ugyanolyan jogok illetik meg őket, mint bárki mást. A könnyen érthető kommunikáció terjesztésével kapcsolatban nem ütköznek semmilyen akadályba. Sőt, azt tapasztalják, hogy inkább támogatják őket, például a hatóságok is kérik, hogy szerezzenek be számukra könnyen érthető kiadványokat, illetve segítsenek az ilyen kiadványok létrehozásában.

Szegedi Erika elmondta, hogy megyei egyesületként az a feladatuk, hogy az értelmi sérült embereknek megadják a kommunikációs támogatást. Ezt az interneten keresztül terjesztett, illetve nyomtatott kiadványok útján biztosítják. Amikor az akadályokról kérdeztem, pozitívan állt a dolgokhoz: „Nincs olyan akadály, amit ne tudnánk átlépni, vagy elgördíteni magunk elől!"

\section{Mit tesz az ÉFOÉSZ a módszer népszerüsítése érdekében? Milyen eredményeket értek el eddig?}

Czakó Tibor szerint az ÉFOÉSZ munkásságából kiemelendő, hogy maguk is részt vettek a könnyen érthető kommunikáció európai irányelveinek a kidolgozásában. Ez volt az Európai Unió által támogatott, Pathways 1. nevű projekt, amit az európai ernyőszervezetként működő Inclusion Europe fogott össze. Kilenc ország érdekvédői dolgoztak együtt a programban. A program részeként megszervezték a képzők képzését is, amelynek keretében Bercse László is tanúsítványt szerzett. Bercse László már a sorstársainak is tartott képzést.

Czakó Tibor szerint a könnyen érthető kommunikáció nem csak az értelmi sérült embereknek lehet nagyon fontos, hanem bárki másnak, aki valamilyen oknál fogva nehezebben érti meg a hagyományosan megfogalmazott üzeneteket. Az index. hu információs portállal való együttműködésben az önkormányzati választások előtt például az ÉFOÉSZ munkatársai és az Index újságírói könnyen érthető cikkeket írtak a hírportálra. Valószínüleg az index.hu olvasói közül sokan szívesen fogadták ezeket a híreket. Az önkormányzati választások napján a folyamatosan frissülő percről percre rovatban néhány óránként könnyen érthető összefoglalók is megjelentek. Talán megértették az index.hu munkatársai a könnyen érthető üzenetek hasznosságát, amikor vállalkoztak az együttmüködésre.

Nagyon aktuális, hogy a koronavírus-járványról minden nap jelenik meg az ÉFOÉSZ Facebook oldalán és a honlapján egy könnyen érthető hírösszefoglaló. Van az ÉFOÉSZ-nak egy könnyen érthető blogja is. Ez utóbbit éppen az interjút adó Sallai Ilona, Czakó Tibor és Bercse László szerkesztik.

Van továbbá egy, az Európai Unió által finanszírozott EFOP pályázati programja is az ÉFOÉSZ-nak, meséli tovább Czakó Tibor. Az országban minden megyében és 
Budapesten létrehoztak egy-egy központot, ahol legalább egy önérvényesítő dolgozik, van, ahol kettő is. Az önérvényesítő munkatársaknak a szerződései és a munkaköri leírásai is könnyen érthető nyelven készültek el.

Czakó Tibor szerint nagyon fontos az is, hogy a módszerről tudjanak az érintett célcsoportot segítő emberek. Ezért szerveznek a szociális szakembereknek szóló képzéseket. Vannak továbbá egyetemeken tartott képzéseik is. Együttmüködnek az SZTE JGYPK Gyógypedagógus-képző Intézetével és az ELTE Bárczi Gusztáv Gyógypedagógiai Karral. Így a gyógypedagógia alapszakos hallgatók is megismerhetik ezt a módszert, és amikor elkezdenek a gyakorlatban dolgozni, akkor azonnal alkalmazni is tudják.

Fontos továbbá a társadalmi szemlélet formálása. Amikor Czakó Tibor és munkatársai konferencián előadást tartanak, akkor is könnyen érthető diasort készítenek, ha nem értelmi sérült emberek ülnek a hallgatóság soraiban. Így sokan megtapasztalhatják a könnyen érthető prezentáció külalakját és tartalmi felépítését.

Czakó Tibor megerősítette azt, hogy az önérvényesítő csoport müködését kiemelten fontosnak tartják. Minden anyagot, amit nekik szánnak, könnyen érthető módon készítenek el.

Sallai Ilona elmondta, hogy jártak a budapesti Csalogány EGYMI-ben is, ahol az önérvényesítésröl és a könnyen érthető kommunikáció fontosságáról beszéltek. Gyógypedagógusoknak tartották az előadást annak érdekében, hogy útmutatást adjanak nekik a minél hatékonyabb kommunikációhoz. A Csalogány EGYMI-ben kisgyermekkortól felnőttkorig jelen vannak az értelmi sérült emberek. Ezért fontos az, hogy az érintettek szükségleteihez mérten tudják a gyógypedagógusok átadni az információkat.

Sallai llona beszélt arról is, hogy az ÉFOÉSZ keretein belül a könnyen érthető kommunikációt alkalmazzák például csoportfoglalkozásokon is. Fontosnak tartják, hogy az érintettek jogtudatosabbak legyenek, ezáltal az önérvényesítés ne legyen nekik nehéz. Mindemellett alkalmazzák még a honlapjuk készítésekor, projekteknél és kiadványok írásánál is.

Jenei Klára elmondta, hogy a Csongrád-Csanád megyei ÉFOÉSZ szervezetnek is vannak saját könnyen érthető kiadványaik, de a központi ÉFOÉSZ-tól is szoktak átvenni, és azokat is népszerüsítik. Mindemellett a másik oldalról is megközelítik a könnyen érthető kommunikációt - az érintettek oldaláról. Úgy gondolja, hogy fontos az értelmi sérült emberek megerősítése annak érdekében, hogy ők is oda merjenek menni másokhoz például segítséget kérni, vagy elmondani azt, hogy mi a problémájuk. Ahhoz viszont, hogy ezt meg tudják tenni, a kommunikációt gyakorolniuk kell. Nagyon sok olyan foglalkozást tartanak, ahol ezt helyezik a fókuszba. Jenei Klára szerint sokat segít az, ha vannak olyan önérvényesítők, akik ki mernek állni, és képviselik önmagukat és a társaikat is. Így példát mutatnak társaik számára is.

Jenei Klára szerint a Csongrád-Csanád megyei ÉFOÉSZ irodán belül mindig törekednek arra, hogy könnyen érthetően kommunikáljanak másokkal a mindennapok során. A szülőknek is tartottak már felkészítő képzést. Az elnökségi üléseken is rendszeresen előkerül ez a téma. Akikkel szorosabban együtt dolgoznak, velük mindig megbeszélik, hogy mit kellett volna esetleg másképp mondani, illetve munka közben is visszajeleznek egymásnak, kiegészítik egymást.

Schriffertné Locskai Henriett is mesélt a fent már említett EFOP pályázati programról. Ennek keretében 8 témában adtak ki könnyen érthető kiadványokat. A Békés 
megyei szervezet ezen témakörök mentén szervezett programokat a megye területén - többek között - szociális intézményekben. Az említett kiadványok ingyenesen letölthetők az efoesz.hu honlapról. Arra törekszenek, hogy a központi ÉFOÉSZ által kiadott könnyen érthető tájékoztatókat helyben minél hatékonyabban tudják felhasználni. Az elmúlt évben az egyik kolléganőjével könnyen érthető társasjátékot is fejlesztettek.

Melcher Györgyné a családoknak szervezett szabadidős rendezvényeket emelte ki. Ilyen például a nyári nyaraltatás a Szelidi-tó partján. Ilyenkor nagy hangsúlyt fektetnek a könnyen érthetőségre. Ez azt jelenti, hogy próbálnak a reggeli tornától kezdve a főzésig mindent közösen és a táborozók számára érthető módon végezni. Természetesen ezekbe a táborokba is magukkal viszik a könnyen érthető kiadványokat. Például a főzéshez kiválóan tudják használni a képekkel illusztrált szakácskönyveket. Emellett például a háztartási gépek üzemeltetését is a kiadványok segítségével tudják megtanítani.

Szegedi Erika elmondta, hogy a helyi önkormányzat nem csak támogatja a helyi ÉFOÉSZ-t, hanem együtt is müködnek. A helyi esélyegyenlöségi programban is szerepel legalább a könnyen érthető honlapok szükségessége. Az önkormányzattal közös céljuk, hogy városszerte könnyen érthető tájékoztató táblákat helyezzenek el. Így nemcsak számítógépen és interneten keresztül tudnak az érintettek könnyen érthető információkhoz jutni. Elmondta továbbá, hogy korábban tartottak már érzékenyítő tréningeket hatóságok részére is, például rendőrségnek, bíróságnak, kormányhivatal dolgozóinak. Saját maguk számára pedig nyelvi tolmácsolásra felkészítő továbbképzést szerveztek. Jelenleg azon dolgoznak, hogy a kialakult koronavírus-járvánnyal kapcsolatos tudnivalókról (például kézmosás, távolságtartás) könnyen érthető módon tájékoztassák az értelmi sérült embereket. Elsősorban azokat az értelmi sérült személyeket próbálják elérni, akik nem családban élnek.

Bercse László és Czakó Tibor rendszeresen vesznek részt külföldön nemzetközi konferenciákon és nemzetközi műhelymunkákban, ahol mindig könnyen érthetően kommunikálnak egymással. Bercse László az EPSA (Európai Önérvényesítő Platform) elnöke.

Czakó Tibor ehhez hozzátette, hogy az EPSA-nak háromhavonta jelenik meg könnyen érthető hírlevele - az „Európa nekünk” („Europe for us”). Ez a hírlevél több nyelven is megjelenik, angolul írják Brüsszelben, amit több országban fordítanak le az adott országban használt anyanyelvre, így magyar nyelvre is. Az újságban a nemzetközi érdekvédő munkával, önérvényesítéssel kapcsolatos híreket közölnek. A korábbiakban már bemutatott képzéseken túl számos, a társadalmi tudatformálást szolgáló képzést szerveztek például bíróknak, rendőröknek. Az Európai Parlament tagjainak választási időszakában erről szóló könnyen érthető kiadványokat készítettek.

Sallai Ilona elmesélte, hogy Horváth Péter Lászlóval a németországi Hildesheim egyetemén jártak, ahol többek között a könnyen érthető kommunikációt kutatják. Itt egy konferencia keretében előadást tartottak a könnyen érthető kommunikáció participatív oktatásának tapasztalatairól. A május 5-i önálló életvitel nemzetközi napja alkalmából minden évben szerveznek rendezvényeket értelmi sérült emberekkel közösen. Ilyenkor is szükség van a könnyen érthetöségre.

Jenei Klára azt emelte ki, hogy sok civil szervezettel müködnek együtt, például a vak és gyengénlátó, halmozottan fogyatékos embereket képviselő civil szervezetek- 
kel. Velük közös programokat szerveznek, például kirándulásokat. Ilyen esetekben kölcsönös a társadalmi tudatformálás. Mindig beszélnek a könnyen érthető kommunikációról is, ami így egyre több emberhez is eljuthat. Igyekeznek a helyi önkormányzat felé is nyitni, illetve kapcsolatot teremteni. Tartottak már esélyegyenlőségi gálát, több nagyobb rendezvényt és fórumokat. llyenkor törekszenek a médianyilvánosság biztosítására. A helyi újságokban és a városi televízióban is kaptak már lehetőséget a szereplésre, így tudják a hírét vinni a könnyen érthető kommunikációnak.

A Melcher Györgyné által képviselt szervezet többek között a bajai Fogyatékosok Nappali Intézményébe vagy a kalocsai Értelmi Fogyatékosok Napközi Otthonába juttat el könnyen érthető kiadványokat, például orvosi vizsgálatokkal kapcsolatban (méhnyakrákszürésről, mellvizsgálatról). A cél az, hogy az értelmi sérült emberek is megismerjék és megértsék a preventív egészségügyi vizsgálatok fontosságát. Ugyanakkor tartottak már tájékoztatást a témáról olyan hivatalnokoknak is, akik kapcsolatban állhatnak értelmi sérült személyekkel. Azt javasolták a közintézmények képviselőinek, hogy ők is gondoskodjanak könnyen érthető kiadványokról. Fontos eredmény, hogy vannak már olyan hivatalok is, amelyek képviselői maguk kérik a segítséget az ÉFOÉSZ helyi szervezetétől a fordítások elvégzéséhez, illetve igénylik, hogy kaphassanak a központilag kiadott könnyen érthető kiadványokból.

Szegedi Erika is a kiadványok terjesztésében látja a lehetőséget, hiszen a megyében nagyon sok értelmi sérült személynek szolgáltatást nyújtó intézmény működik. Ezáltal egyre több helyre eljut a könnyen érthető kommunikáció, és hasznát is veszik a kiadványoknak. Ök is törekszenek arra, hogy a helyi önkormányzattal, a várossal, illetve más önkormányzatokkal is jó kapcsolatot ápoljanak. Közös törekvésük, hogy a kormányhivatalokban is elérhetővé váljanak a könnyen érthető kiadványok.

\section{Hol és milyen formában találkozhatunk a könnyen érthető kommunikációval az ÉFOÉSZ keretén kívül?}

Czakó Tibor a Nemzeti Fogyatékosságügyi és Szociálpolitikai Központot ajánlja figyelmünkbe. A Központ számos könnyen érthető kiadványt készít és terjeszt. Javasolta továbbá Farkasné Gönczi Rita honlapját, amely kifejezetten a könnyen érthető kommunikációval foglalkozik, és ahonnan ugyancsak sok könnyen érthető anyagot lehet letölteni. És végezetül tanácsolta a Down Alapítványt is.

Sallai Ilona a Szegedi Tudományegyetem Juhász Gyula Pedagógusképző Kar innovációjára hívta fel a figyelmet.

Schriffertné Locskai Henriett elsősorban a gyógypedagógiai köznevelési intézményeket emelte ki, illetve bizonyos integráló óvodákat és iskolákat. Úgy gondolja, hogy ezeken a helyeken különösen felkészültnek kell lenni a könnyen érthető kommunikációt illetően.

\section{ÖsSZEFOGLALÁs}

A könnyen érthető kommunikáció Magyarországon is fokozatosan, lépésröl lépésre terjed. Az ÉFOÉSZ és az ernyőszervezet tagszervezetei komoly erőfeszítéseket tesznek annak érdekében, hogy a könnyen érthető kommunikációról szóló tájékoz- 
tató előadásokkal, a könnyen érthető kommunikációra felkészítő képzésekkel, illetve könnyen érthető kiadványok készítésével és azok kiadásával hozzájáruljanak az értelmi sérült személyek minél önállóbb életviteléhez. Az ÉFOÉSZ hitelesen tudja képviselni a könnyen érthető kommunikáció ügyét, hiszen az értelmi sérült embereknek és az értelmi sérült emberekkel közösen szervezett események (például klubok, mühelyek, szabadidős tevékenységek, konferenciák stb.) nem is képzelhetők el a könnyen érthetö kommunikáció nélkül.

Bízom abban, hogy a tisztelt olvasó legalább alapszintű betekintést nyert a könynyen érthető kommunikáció gyakorlatának világába. Javaslom, hogy kísérjék figyelemmel ezt az innovatív munkát a beszélgetőtársak által javasolt, itt elérhető honlapok követésével.

Ezen a térképen most nem vált látható az ÉFOÉSZ valamennyi tagszervezetének munkája, és más civil szervezeti kezdeményezések bemutatására sem került sor. Ugyanakkor remélem, hogy a közeljövőben újabb (például szakdolgozati) kutatások születnek a témában, és ezek eredményeként egyre több törekvésről és alkalmazási területről informálódhatunk a könnyen érthető kommunikációval kapcsolatban.

\section{Ajánlott honlapok:}

a Down Alapítvány honlapja: https://www.downalapitvany.hu/node/337

az „Együtt Velünk - Önérvényesítés” honlap: http://egyuttvelunk.onervenyesites.hu/

az ÉFOÉSZ honlapja: https://efoesz.hu/

Farkasné Gönczi Rita honlapja: http://konnyenertheto.gonczirita.hu/

a Nemzeti Fogyatékosságügyi- és Szociálpolitikai Központ honlapja: https://fszk.hu/?s=könnyen+érthető

a „Könnyen Érthető Információs Központ létrehozása” projekt FB oldala: https://www.facebook.com/konnyenertheto

\section{Irodalom}

Fogyatékossággal élő személyek jogairól szóló ENSZ egyezmény, 2006

Farkasné Gönczi R. \& Graf-Jaksa É. (2009). Könnyen érthető kommunikáció. In Pandula A., Szatmári P., Vincze T., Farkasné Gönczi R. \& Graf-Jaksa É. (szerk.), Kommunikációs és információs technológiák és fogyatékosságügy. ELTE Bárczi Gusztáv Gyógypedagógiai Kar, Budapest. 80-100.

Madridi Nyilatkozat (2003). „A befogadó társadalom alapja a diszkrimináció-mentességgel párosuló pozitív cselekvés.” http://www.msmke.hu/tamogat/madnyil.pdf Letöltés ideje: 2020.04. 08.

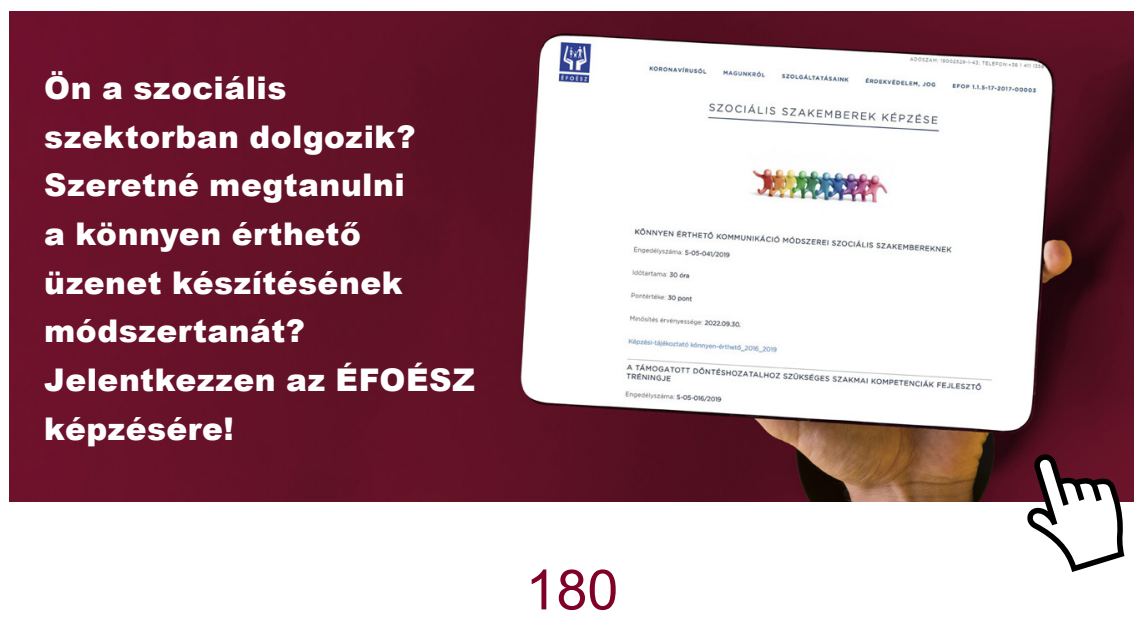




\title{
AT, GYSE, IKT, AAK... Az önálló életvitelt támogató- segítő eszközök és technológia - fogalmi tisztázás és helyzetkép
}

\begin{abstract}
A tanulmány az önálló életvitelt támogató-segítő eszközök és technológia fogalmát igyekszik tisztázni. A magyar jogszabályokban a támogató-segítő eszközök megnevezése (gyógyászati segédeszközök) és tartalma elavult, nem követi a nemzetközi trendeket és irányelveket, aminek egyik következménye, hogy az állami - társadalombiztosítási - támogatással elérhető eszközök listája jelentős elmaradásban van a piaci kínálathoz képest; ez egyik közvetett gátja az eszközök hozzáférhetöségének.

Kulcsszavak: támogató-segítő eszközök és technológia; támogató technológia; asszisztív technológia; gyógyászati segédeszköz
\end{abstract}

\section{BeVezetés}

A technológia szinte mindenütt jelen van, számos formája az egyén, a család, a szükebb-tágabb közösségek mindennapjainak részévé vált. Néha láthatatlan: müködik távoli vezérléssel is, kontrollálhatja ember, ugyanakkor képes az emberi cselekedetek kontrollálására. Miközben a technológiai megoldások a mindennapi életben leggyakrabban a kényelmet szolgálják, a fogyatékossággal élő személyek életében a támogató funkciók felértékelődnek, gyakorta ezen eszközök által válnak lehetővé olyan tevékenységek, amelyek a fogyatékossággal nem élő személyek számára természetesek, mindennaposak.

Legyen szó akár egyszerű, kézzel fogható eszközről, mint a járóbot, akár fejlettebb technológiákról, mint a mesterséges intelligencia, a testi-mentális funkciók monitorozására, diagnosztizálására, kezelésére, helyettesítésére, támogatására használható eszközök és rendszerek a hétköznapi tevékenységeken túl a társas kapcsolatokra, sőt, a társadalmi részvétel megannyi területére is hatást gyakorolnak. Azon túl, hogy hozzájárulnak a fogyatékossággal élő emberek független, méltóságteljes, produktív életviteléhez, lehetővé tehetik, hogy használójuk be- vagy visszailleszkedjen a munka világába, a szűkebb-tágabb közösségi életbe: egy kapcsolóval működtethető játék megteremtheti az esélyt egy fogyatékossággal élő gyermeknek a közös játékra, így a közösségi részvételre; egy mobilitást támogató eszköz segítheti az egyént, hogy eljusson a munkahelyére; bizonyos eszközök a munkavégzéshez járulnak hozzá vagy a munkakörnyezetet akadálymentesítik. „(...) úgy is szokták megfogalmazni, hogy a fogyatékosság súlyosságát azoknak a segédeszközöknek, valamint személyi segítségnek a minősége és mennyisége szabja meg, amely az 
illető életvitelének normalizálásához, az elérhető legnagyobb önállóságához és a lehető legmagasabb szintű társadalmi részvételéhez szükséges. A jó segédeszközök, amelyekre bármely fogyatékosság esetén szükség lehet, rendkívül sokat jelenthetnek mind a használónak, mind a családnak" (Könczei \& Kálmán, 2002) - és a társadalomnak is.

A segédeszközöké interdiszciplináris, az utóbbi két évtizedben egyre inkább virágzó kutatási terület, miképpen napról napra a piacon is számos új eszköz és technológiai megoldás jelenik meg, amelyek valamilyen módon - szándékoltan vagy nem szándékoltan - segédeszközként (is) funkcionálhatnak. Az önálló életvitelt támogató eszközöket a nemzetközi szakirodalomban a nyolcvanas évek óta használatos „assistive technology" (AT) ernyőfogalom foglalja össze. A meghatározás bár viszonylag új, fordítása a magyar nyelvben alig terjedt el. A Fogyatékossággal élő személyek jogairól szóló ENSZ egyezményben (továbbiakban: fogyatékosságügyi ENSZ egyezmény) szerepel (lásd részletesebben később) az „assistive technology” kifejezés, az elfogadásáról szóló törvény magyarul támogató-segítő eszközként, azaz támogató technológiaként utal rá. Mégis a jogalkotó fogalomhasználata nem következetes: hol segédeszköz, hol gyógyászati segédeszköz kifejezéseket találunk a vonatkozó jogi dokumentumokban, ráadásul helyenként eltérő tartalommal.

A megnevezésbeli és ebből fakadó tartalmi inkonzisztencia nem csak fogalmazási kérdés: ebben az írásban arra igyekszem választ adni, hogy milyen következményei vannak a következetlen fogalomhasználatnak az eszközök hozzáférhetőségének mértékére és módjára. Jelen tanulmány arra vállalkozik, hogy bevezesse a nemzetközi szakmai közegben használt támogató technológia fogalmat, ezen keresztül tisztázza a magyar jogi dokumentumokban, irányelvekben és szabványokban keveredő tartalmi elemeket, és rávilágítson az egyértelmü terminológia szükségességére. A megállapítások egy 2016 és 2020 között zajló PhD-kutatás részeredményein alapulnak, amely kutatás a támogató technológia magyarországi hozzáférhetőségével, ezen belül is a társadalombiztosítási támogatással elérhető segédeszközökkel foglalkozik. Ebben az írásban kizárólag az eszközökre fókuszálva, csak a megnevezéssel és tartalommal összefüggő hozzáférési kérdésekre térek ki.

\section{MI ÉS MI NEM TÁMOGATÓ TECHNOLÓGIA?}

Bizonyos „egyszerü” segédeszközök - például botok, protézisek - évezredek óta segítik a valamilyen fogyatékosságban érintett embereket. Kevés információ áll rendelkezésünkre, és igen nagy eltérések vannak abban, hogy az egyes fejlett államok szolgáltatásai között mikor és milyen formában váltak elérhetővé a segédeszközök. Az viszont tudható, hogy a 20. századi világháborúkban részt vevő országok a háborús sérültjeik számára már biztosítottak egyes eszközöket, leginkább végtagprotéziseket (Weinhoffer, 2017). Az első elérhető eszközök szinte kizárólag csak biológiai szükségletekre reagáltak, így kieső testi funkciókat pótoltak. A hatvanas évektöl kezdődően nem csak a technológia fejlődött ugrásszerüen, de ezzel párhuzamosan a fogyatékosság fogalma körül is paradigmaváltás zajlott. Az emberi jogi szemlélet és az önálló életvitel szempontjainak előtérbe kerülése magával hozta, hogy a segédeszközökre elkezdtek úgy gondolni, mint amik nem csak testi hiányosságokat kompenzálnak, de hozzájárulnak a közösségben való részvételhez is. Vagyis az 
eszközök segítségével nem megjavítani lehet és kell a testi fogyatékosság okozta hiányosságokat [lásd orvosi-medikális szemlélet, például Goodley (2019)], hanem kiaknázni a meglévő képességeket, hozzásegíteni az egyént, hogy minél önálóbb életet élhessen, gyakorolhassa állampolgári jogait, részt tudjon venni a társadalmi életben, a munkaerőpiacon, az oktatásban. Ez a változás a segédeszközök nevében és definíciójuk tartalmában is felfedezhető: az egészségügyi eszközök, rehabilitációs eszközök (a nemzetközi szakirodalomban „aid”, „medical aid”, „medical device” stb.) megnevezések helyett a(z önálló életvitelt) támogató eszközök és technológia („assistive device”, „assistive technology”) kifejezést kezdték használni a szakemberek és az érintettek.

E szemléletváltásban élenjáró volt az Egyesült Államokban az 1988-as, a fogyatékossággal élő személyeknek szóló technológiai alapú segítésről szóló törvény (Technology Related Assistance to Individuals with Disabilities Act of 1988), ami elöször vezette be és definiálta az „assistive technology device” kifejezést: „bármely kereskedelmi forgalomba hozott, kész, átalakított vagy személyre szabott termék, berendezési tárgy, eszköz, amit azért használnak, hogy a fogyatékossággal élő személyek funkcionális képességeit erősítse növelje, megtartsa vagy fejlessze" [a szerző fordítása]. Emellett, a törvény meghatározta a támogató technológiai szolgáltatásokat is („assistive technology services”): „bármely szolgáltatás, ami közvetlenül segíti a fogyatékossággal élő személyt a támogató technológiai eszköz kiválasztásában, beszerzésében vagy használatában" [a szerző fordítása]. A törvény és az Egyesült Államokban általa biztosított szolgáltatási környezet nemzetközi szinten is ráirányította a figyelmet egyrészt a támogató technológiára, másrészt arra is, hogy önmagukban az eszközök nem elegendők a társadalmi hátrányok leküzdéséhez. A kapcsolódó szolgáltatások, mint például a méretre igazítás, az adaptálás, a betanítás, az utánkövetés nélkül az eszközök könnyen kényelmetlenné és használhatatlanná válhatnak. Sőt, a nem megfelelő segédeszköz-használatnak további, megelőzhető egészségkárosodás lehet a következménye (például felfekvések, deformációk).

Az elöremutató törekvések ellenére a támogató eszközöknek és technológiának nincs egységesen használt definíciója. Az utóbbi évek nemzetközi kutatásai és elemzései az Egészségügyi Világszervezet (WHO) definícióját használják. Khasnabis, Mirza és MacLachlan (2015) nyomán a WHO hasonlóan megkülönbözteti a támogató eszköz (,assistive device”) és a támogató technológia („assistive technology”) terminusokat:

1. „a támogató eszközök olyan testen kívüli eszközök, amelyek elsődleges célja, hogy fenntartsák vagy fejlesszék az egyén képességeit és önállóságát, ezáltal hozzájáruljanak a jólétéhez";

2. „a támogató technológia kifejezés - az egészségügyi technológiák részhalmazaként - olyan segédeszközökre, valamint hozzájuk kapcsolódó rendszerekre és szolgáltatásokra utal, amelyek azért jöttek létre, hogy fenntartsák vagy fejlesszék az egyén képességeit, ezáltal hozzájáruljanak a jólétéhez" [a szerző fordításai és kiemelései]. (Egészségügyi Világszervezet, 2018:1)

Az Egészségügyi Világszervezet álláspontjának megfelelően támogató technológia kifejezést egyes számban használom, ami mögött húzódó megfontolás, hogy a többes számú támogató technológiák kifejezés ne keltse azt a téves látszatot, hogy csupán különböző eszközöket fed a fogalom. A támogató technológia magába foglalja azt a teljes ökoszisztémát, amelyre szükség van a segédeszközök biztonsá- 
gos és hatékony használatához és szolgáltatásához. Számos AT területén dolgozó szakember, illetve az Association for the Advancement of Assistive Technology in Europe (AAATE) ernyőszervezet is az asszisztív megoldások („assistive solutions”) kifejezés használatát javasolja: ez ugyanis egy olyan egyénre szabott szolgáltatási csokrot kínál, amiben nem csak az eszközök, hanem a kapcsolódó szolgáltatások is benne vannak, továbbá magába foglalja az összes technológiai (ideértve a támogató és a mainstream technológiákat is) és személyi segítést, valamint a környezeti adaptációt, ami a fogyatékossággal élő emberek társadalmi részvétele előtt álló korlátokat hivatott ledönteni (AAATE, 2003). Az asszisztív megoldás „három A” elem együttese: támogató eszközök és technológiák („assistive technology”), személyi segítés („personal assistance”), és egyéni környezet-adaptáció („individual environmental adaptations"). Minden elemnek lehet segítő és hátráltató funkciója is, attól függően, hogy egymással milyen kombinációban és kölcsönhatásban müködnek (Andrich \& mtsai, 2013).

Szembetűnő, hogy a WHO definíciója nem jelöli ki a célcsoportot, a támogató technológia potenciális felhasználóit, és ez tudatos. Feltételezhetjük ugyanis, hogy a segédeszközök iránti szükséglet nem kötődik feltétlenül fogyatékossághoz vagy tartós egészségkárosodáshoz, azok „klasszikus” definíciói vagy diagnózisai szerint. Ugyanakkor, a szervezet álláspontja szerint azok a személyek, akiknek leginkább szükségük van AT-re, a fogyatékossággal élő emberek, az idős emberek, a krónikus betegségekben érintettek (például stroke-on átesett emberek, cukorbetegek), a mentális állapotuk miatt korlátozott emberek (köztük a demens és az autizmus spektrumba tartozó emberek), illetve a fokozatos funkcióromlással érintettek (Egészségügyi Világszervezet, é.n.). A WHO becslései szerint világszerte egymilliárd embernek lenne szüksége a mindennapjaiban legalább egy(féle) segédeszközre. A globális idősödési trendek és a krónikus betegségek prevalenciájának növekedése miatt a kielégítendő szükségletek folyamatos bővülésére számíthatunk, ami 2030-ra számokban kifejezve a kétmilliárdot is meghaladó potenciális felhasználói létszámot jelenthet (Egészségügyi Világszervezet, 2018).

Ha elfogadjuk az Egészségügyi Világszervezet gyakran idézett tág definícióját, támogató eszköz és technológia még mindig sok minden lehet. Lehet egyszerü, „low-tech” eszköz, mint a fehérbot, és lehet ennek ellenkezője is, „high-tech” segítő robot. Lehet bárki által használható eszköz, ami nem kötődik kifejezetten fogyatékossághoz, mint például egy nagyító, és lehet bizonyos szükségletekre fejlesztett eszköz, mint például a Braille írógép. De támogató technológiaként funkcionálhatnak tömegtermékként gyártott eszközök is, mint a számítógépek, a tabletek, amelyek bizonyos esetekben lehetővé tehetik egy beszédfogyatékos ember kommunikációját vagy segíthetik egy autista gyermek napirendjének követését. Fontos, hogy a támogató-segítő eszközöket és technológiát, illetve a hozzájuk kapcsolódó szolgáltatásokat elkülönítsük a leggyakrabban kórházi körülmények között használt orvosi technológiáktól, a munkahelyen munkavégzésre használatos gépektől, technológiáktól és az ápolást, gondozást, szociális segítést végző szakemberek munkavégzését támogató jóléti technológiáktól („welfare technology”; erről lásd például Cozza és $m t s a i, 2019)$, még akkor is, ha ezekben alapvetően közös az emberi tevékenységek támogatása, a mindennapi élet megkönnyítése. Az operacionalizálásban 1992 óta az ISO:9999 szabvány (International Organization for Standardization: Assistive products for persons with disability - Classification and terminology) segít, ami funkció 
szerint osztályozza a segédeszközöket. Ennek értelmében, támogató technológia „bármely, fogyatékossággal élő emberek által vagy érdekében használt, speciálisan tervezett vagy általánosan elérhető termék (köztük eszközök, berendezések, készülékek és szoftverek), amik a társadalmi részvételt, a testi funkciók és tevékenységek támogatását, fejlesztését, mérését vagy helyettesítését szolgálják, illetve a károsodás, a tevékenységbéli akadályozottság vagy a társadalmi részvétel korlátozottságának megelőzésében használatosak" [a szerző fordítása]. (International Standards Organisation, 2016) A szabvány háromszintű rendszerbe sorolja az eszközöket, eszerint támogató eszközök a következő főcsoportokba tartozó termékek:

04 Segédeszközök testi funkciók mérésére, támogatására, képzésére vagy helyettesítésére

05 Segédeszközök oktatáshoz és készségek gyakorlásához

06 Testen viselt, neuromuszkuláris vagy mozgással összefüggő funkciókat támogató eszközök (ortézisek) és testrészeket pótló eszközök (protézisek)

09 Az önellátás és a személyes gondoskodásban való részvétel segédeszközei

12 Személyes mozgással és utazással kapcsolatos tevékenységek és részvétel segédeszközei

15 Segédeszközök háztartásban végzett tevékenységekhez és a családi életben való részvételhez

18 Bútorzat, berendezési tárgyak és egyéb segédeszközök bel- és kültéri épített környezetben végzett tevékenységek támogatásához

22 Segédeszközök kommunikációhoz és az információ feldolgozásához

24 Segédeszközök tárgyak és eszközök müködtetéséhez, tartásához, mozgatásához és kezeléséhez

27 Segédeszközök a fizikai környezet ellenörzéséhez, adaptálásához vagy környezeti elemek méréséhez

28 Segédeszközök munkavégzéshez és foglalkoztatásban való részvételhez

30 Segédeszközök kikapcsolódáshoz és pihenéshez

A szabvány egy szakmai testület döntései alapján, figyelembe véve a piaci változásokat és a releváns szakmai irányelveket, négyévente frissül, jelenleg a 2016-ban megjelent, hatodik kiadás van érvényben, a következő verziója készül. Rendszeres felülvizsgálatának egyik fontos célja, hogy fogódzót nyújtson a szakembereknek, a jogalkotóknak és a döntéshozóknak arról, milyen eszközök és technológiai megoldások segítik a fogyatékossággal élő embereket.

\section{MIT TAKAR A TÁMOGATÓ TECHNOLÓgIA MAGYARORSZÁGON?}

A magyar jogszabályokban az önálló életvitelt támogató eszközökre nem a támogató technológia, hanem a gyógyászati segédeszköz kifejezés intézményesült (Menich, 2016). Ennek oka feltételezhetően az, hogy az első segédeszközök német mintára, valószínűsíthetően a régi német megnevezést lefordítva (Pflegehilfsmitteln) jelentek meg Magyarországon, és bár azóta a német megnevezésből is eltűnt az eredetileg gyógyászatnak fordított Pflege- előtag, a magyar fordítás nem követte maradékta- 
lanul a nemzetközi változásokat. A gyógyászati segédeszköz kifejezés a biztosítási törvény egészségkárosodással foglalkozó törvénycikkében jelent meg elöször, az 1900-as évek elején, de máig nincs egységes definíciója a magyar jogi dokumentumokban. A jelenleg hatályos jogszabályokban a gyógyászati segédeszközöknek három eltérő definíciója is létezik, a Nemzeti Egészségbiztosítási Alapkezelő (NEAK, 2021) honlapján pedig egy negyedik meghatározás olvasható:

100. § (6): „A gyógyászati segédeszközök az alapvető életműködések megtartását, illetve a kiesett funkciók pótlását szolgálják és ezáltal az önfenntartó képességet, az életminőséget és a munkaképességet javítják" (Eütv., 1997).

4. § c): "segédeszköz: a fogyatékos személy fizikai vagy érzékszervi képessége részleges vagy teljes hiányának részleges vagy teljes pótlását szolgáló eszköz" (Fot.).

3. § 6.: "gyógyászati segédeszköz: átmeneti vagy végleges egészségkárosodással, fogyatékossággal élő ember személyes használatába adott orvostechnikai eszköz (beleértve az önellenörzési célt szolgáló in vitro diagnosztikai orvostechnikai eszközt is), vagy orvostechnikai eszköznek nem minősülő ápolási technikai eszköz, amely használata során nem igényli egészségügyi szakképesítéssel rendelkező személy folyamatos jelenlétét. Személyes használatnak minősül az eszköz természetes vagy mesterséges testfelszíni nyílással rendelkező testüregben, vagy testen történő viselése, alkalmazása, ideértve az önellenörzési célt szolgáló in vitro diagnosztikai orvostechnikai eszközök emberi szervezetből származó mintán történő alkalmazását is, valamint a test megtámasztására, mozgatására szolgáló eszköz igénybevétele diagnosztikus, terápiás, rehabilitációs, vagy ápolási céllal" (Gyftv., 2006).

NEAK: „A gyógyászati segédeszközök (gyse) a gyógyító eljárás során és a rehabilitációban is fontos szerepet töltenek be, a gyógyulási folyamatban a beteg életminőségének javítását szolgálják. Gyógyászati segédeszköznek azt az átmeneti vagy végleges egészségkárosodással, fogyatékossággal élő ember személyes használatába adott orvostechnikai-, vagy ápolási technikai eszközt tekintjük, amely használata során nem igényli egészségügyi szakképesítéssel rendelkező személy folyamatos jelenlétét" (NEAK, 2021.).

Amellett, hogy a szabályozás nem egységes, valamennyi definíció szükebb, mint a nemzetközi szakmai közegben használt támogató technológiáé; egyrészt kijelölik a célcsoportot (fogyatékossággal élők és egészségkárosodott személyek, betegek), másrészt a használat helyét és módját (a gyógyító eljárásban, személyes, egyéni, szaksegítség nélkül), harmadrészt az átmenetileg vagy tartósan kieső funkciók pótlását célozzák, és kizárólag eszközökre korlátozódnak. Nemcsak a nem kézzelfogható eszközök hiányoznak a meghatározásokból, hanem a kapcsolódó szolgáltatások is.

A 2007. évi XCII. törvénnyel Magyarország is elfogadta és beépítette a jogrendszerébe a fogyatékosságügyi ENSZ egyezményt, ami azt jelenti, hogy vállalta, betartja a benne foglaltakat. Az egyezményben számos ponton megjelenik a támogató technológia: a részes államok általános kötelezettségeik között fogadták el, hogy biztosítják a megfelelő információkat az elérhető eszközökről és technológiáról, segítik az erre irányuló kutatások és innovációk térnyerését [4. cikk, g)-h) pontok], 
valamint kiemelten támogatják a habilitációhoz és a rehabilitációhoz használatos segédeszközök és technológia „elérhetőségét, ismeretét és használatát” (26. cikk). A fentebb idézett magyar jogszabályi definíciók mindegyike az egyezmény ratifikációja előtt született ugyan, de valamennyi törvényt többször is felülvizsgálták azóta, a változások e meghatározásokat nem érintették. Feltételezhetö, hogy a definíciókban fellelhető orvosi-medikális szemlélet („beteg”, „javulás”, „gyógyítási folyamat”, „funkciók pótlása”) is az elavultság következménye. A támogató technológia kifejezés - valószínűleg részint a jogszabályokban használatos megnevezések miatt a hétköznapi és a tudományos diskurzusokban is viszonylag ritkán fordul elö. A szakemberek - és az érintettek - szóhasználatában különböző kontextusokban hallhatjuk a segédeszköz, a segítő technológia (ST), a rehabilitációs technológia, a gyógyászati segédeszköz (GYSE), az infokommunikációs technológia (IKT), és az augmentatív és alternatív kommunikációs (AAK) eszköz kifejezéseket is, amelyekkel mind-mind az önálló életvitelt támogató eszközök egy-egy kisebb szeletét írják körül.

A magyar GYSE definíciókból a fentiek értelmében arra következtethetünk, hogy a jogalkotó a fogyatékos, az egészségkárosodott és a beteg embereket tekinti az eszközök potenciális felhasználóinak. Magyarországon nem állnak rendelkezésre statisztikai adatok sem a támogató eszközök és technológia iránti szükségletekröl, sem a használatukról, így formális és informális beszélgetéseken, gyakorlati tapasztalatokon és az érdekvédelmi szervezetek információin túl csak következtethetünk arra, hogy mekkora az igény az AT-re. A magyar népességröl legfrissebb reprezentatív adatok a Mikrocenzusból (2016) származnak, ami tartalmazta azt a kérdést, hogy a válaszadók egészségi állapotuk miatt akadályozottnak érzik-e magukat hétköznapi tevékenységeikben. A magánháztartásban élő, erre a kérdésre igennel válaszoló személyek száma közel 1,5 millió - a magyar népesség körülbelül 15 százaléka, a magukat fogyatékossággal élőnek vallók létszámának háromszorosa. Más európai országokhoz képest is szoros összefüggés van Magyarországon az akadályozottság és a szubjektív egészségi állapot között: az akadályozott emberek jelentősen kisebb eséllyel ítélik jónak, és jelentősen nagyobb valószínüséggel érzik rossznak az egészségi állapotukat. (Kozma \& mtsai, 2020; Központi Statisztikai Hivatal, 2018). A nemzetközi trendekhez hasonlóan a magyar népességben is a szükségletek növekedésére lehet számítani, amely szükségletek nem kötődnek feltétlenül diagnózishoz kötött fogyatékossághoz vagy egészségkárosodáshoz, a potenciális felhasználók csoportja heterogén, széles és egyre nő.

Sok más európai országhoz hasonlóan Magyarországon is, bár implicit módon, az ISO:9999 szabvány határozza meg, mely eszközök tartoznak a támogató technológia - a magyar jogszabályi terminológiában gyakrabban használt fogalommal: a gyógyászati segédeszközök - körébe. Ugyanakkor ennek 2002-es verziója van használatban, vagyis az elmúlt több mint egy évtizedben - noha az idöközben három alkalommal (2007, 2011 és 2016) módosult - a magyarországi gyakorlat nem követte a nemzetközi osztályozás változásait. Az elavultság tehát nem csak az AT megnevezésében és definíciójában, de klasszifikációjában is felfedezhető. A frissülés (időpontja) bizonytalan (Tóth \& Mischinger, 2012), 2007 óta már magyar fordítás sem készült a kódrendszerhez. A szabvány eddigi felülvizsgálatai során több főcsoporttal bővült, kivezettek korábbi föcsoportokat, valamint igazodott a fogyatékosság megközelítésében bekövetkező változásokhoz is. Módosult a definíció: például a korábbi magyar fordításban műszaki segédeszközök („technical aids”) helyett segéd- 
eszközök (vö. angol megnevezése eközben már „assistive products” lett), „disabled persons” helyett „persons with disabilities”, ez a magyar fordításban testi fogyatékosok helyett fogyatékkal élők lett és maradt; és módosult egyes föcsoportok megnevezése is, ennek legszembetűnőbb példája a részvétel szó megjelenése például a személyes gondoskodásban (09-es föcsoport) vagy a foglalkoztatásban (28-as föcsoport). A 2002-es és a 2016-os verzió közötti igen jelentős különbségeket az 1. táblázat szemlélteti.

\begin{tabular}{|c|c|c|}
\hline KóD & FŐCSOPORT NEVE & \\
\hline & ISO:9999:2002 & ISO:9999:2016 \\
\hline 02 & Kötszerek & - \\
\hline 04 & Személyes gyógykezelő segédeszközök & $\begin{array}{l}\text { Segédeszközök testi funkciók mérésére, támogatására, } \\
\text { képzésére vagy helyettesítésére }\end{array}$ \\
\hline 05 & & Segédeszközök oktatáshoz és készségek gyakorlásához \\
\hline 06 & Ortézisek és protézisek & $\begin{array}{l}\text { Testen viselt, neuromuszkuláris vagy mozgással összefüg- } \\
\text { gő funkciókat támogató eszközök (ortézisek) és testrésze- } \\
\text { ket pótló eszközök (protézisek) }\end{array}$ \\
\hline 09 & $\begin{array}{l}\text { A személyi gondoskodás és védelem se- } \\
\text { gédeszközei }\end{array}$ & $\begin{array}{l}\text { Az önellátás és a személyes gondoskodásban való rész- } \\
\text { vétel segédeszközei }\end{array}$ \\
\hline 12 & Személyes mozgás segédeszközei & $\begin{array}{l}\text { Személyes mozgással és utazással kapcsolatos tevékeny- } \\
\text { ségek és részvétel segédeszközei }\end{array}$ \\
\hline 15 & Háztartási segédeszközök & $\begin{array}{l}\text { Segédeszközök háztartásban végzett tevékenységekhez } \\
\text { és a családi életben való részvételhez }\end{array}$ \\
\hline 18 & $\begin{array}{l}\text { Bútorzat, lakás- és más helyiség-átala- } \\
\text { kítások }\end{array}$ & $\begin{array}{l}\text { Bútorzat, berendezési tárgyak és egyéb segédeszközök } \\
\text { bel- és kültéri épített környezetben végzett tevékenységek } \\
\text { támogatásához }\end{array}$ \\
\hline 21 & $\begin{array}{l}\text { Segédeszközök a kommunikációhoz, tá- } \\
\text { jékoztatáshoz és jeladáshoz }\end{array}$ & - \\
\hline 22 & - & $\begin{array}{l}\text { Segédeszközök kommunikációhoz és információfeldolgo- } \\
\text { záshoz }\end{array}$ \\
\hline 24 & - & $\begin{array}{l}\text { Segédeszközök tárgyak és eszközök működtetéséhez, tar- } \\
\text { tásához, mozgatásához és kezeléséhez }\end{array}$ \\
\hline 27 & - & $\begin{array}{l}\text { Segédeszközök a fizikai környezet ellenőrzéséhez, adap- } \\
\text { tálásához vagy környezeti elemek méréséhez }\end{array}$ \\
\hline 28 & - & $\begin{array}{l}\text { Segédeszközök munkavégzéshez és foglalkoztatásban } \\
\text { való részvételhez }\end{array}$ \\
\hline 30 & - & Segédeszközök kikapcsolódáshoz és pihenéshez \\
\hline
\end{tabular}

1. táblázat. Az ISO:9999 szabvány 2002-es és 2016-os verziójának összevetése

Megjegyzés: A szabványhoz 2007 óta nem készült hivatalos magyar fordítás. A 2002-es szabvány magyar fordítása a Nemzeti Egészségbiztosítási Alapkezelő oldalról származik, a 2016-os változat pedig a szerző fordítása.

A szabvány több annál, mint hogy funkció szerint csoportba sorolja a támogató-segítő eszközöket. A legtöbb európai országban nemzeti és nemzetközi adatbázisok épülnek rá, és az ISO kódok alapján igényelhetők segédeszközök az állami támo- 
gatás valamely formájával. Így van ez Magyarországon is. Az első támogatott gyógyászati segédeszközök a társadalombiztosítással (tb) egyidőben jelentek meg az ellátórendszerben, és máig tb-ártámogatást vehetnek igénybe azok, akiknek nem áll módjukban piaci alapon, önerőből megvásárolni a szükséges eszközöket. A támogatott gyógyászati segédeszközöknek van egy listája; ez az ISO:9999 szabvány - 2002-es verziójának - kódrendszere alapján sorolja be azokat az eszközöket, amelyek árához tb-támogatás igényelhető. Hogy Magyarországon a szabvány elavult verziója van használatban, nem egyszerủen annyit jelent, hogy a támogató technológia körének meghatározása szűkebb, miként erre már a definíciós különbségekből is következtethettünk. Mivel a tb-támogatással elérhető eszközök listájának föcsoportjai nem követték az elnevezésbeli és tartalmi változásokat, a jogalkotó közvetett gátat szab egyes eszköztípusok támogatott hozzáférhetőségének.

\section{A FOGALOMHASZNÁLATON TÚL}

Az Egészségügyi Világszervezet becslései szerint világszerte a segédeszközök iránt felmerülő szükségletekre csak az esetek 10 százalékában érkezik megfelelő válasz, azaz jól használható eszköz. Más szóval, tízből kilenc ember nem jut hozzá a számára szükséges segédeszközökhöz. A hozzáférés akadályai különböznek a magas és alacsony jövedelmű országokban. Míg az utóbbiakban az elsődleges problémát az eszközök és a szolgáltatások elérhetetlensége és az információhiány okozzák, a magas és közepes jövedelmű országokban a hozzáférés gátja elsősorban anyagi természetü: a társadalmi-gazdasági státuszukat tekintve hátrányos helyzetű emberek és családjaik gyakran nem tudják vállalni az eszközök - esetenként nagyon magas vásárlási, karbantartási, javítási költségeit. Éppen ezért kritikus jelentősége van annak, hogy az államok vállalnak-e felelősséget - és ha igen, miként és mennyit - a támogató technológia hozzáférhetőségének biztosításában, nyújtanak-e támogatást - és ha igen, milyen formában és mértékben - a költségekhez (de Witte \& mtsai, 2018; Egészségügyi Világszervezet, 2018; Gupta \& mtsai, 2011; MacLachlan, 2018).

A Mikrocenzus adatai alapján a népesség körülbelül 15 százaléka tapasztal társadalmi részvételében korlátozottságot, függetlenül attól, hogy fogyatékossággal élőnek vallja-e magát. Az akadályokba ütköző tevékenységek között leggyakrabban a járást, a koncentrációt és emlékezést, az önellátást jelölték meg a válaszadók, a negyedik leggyakoribb nehézség a kommunikáció akadályozottsága. A részvétel mutatói között a munkavégzés és a tanulás jelent meg. Az akadályozott személyek 35 százaléka tapasztalt nehézségeket a közösségi részvétel valamely területén, negyede a családi összejöveteleken való részvételben is. Ezek a leíró statisztikák épp az önálló életvitel és a társadalmi részvétel azon területeit ragadják meg, ahol a támogató technológiának nagy szerepe lehet - ha az hozzáférhető. A szociális szolgáltatások igénybevételéről szóló adatokból levonható egyik következtetés, hogy a szociális ellátórendszer csak korlátozottan biztosítja az önálló életvitelt támogató szolgáltatásokat, nem a társadalmi részvételre céloz, és a személyközpontú támogatásokkal szemben az intézményes formákat részesíti előnyben (Kozma \& mtsai, 2020). Korábbi kutatásokból tudjuk, hogy a fogyatékossággal élő emberek oktatási-foglalkoztatási helyzete, gazdasági aktivitása, jövedelmi helyzete, társadalmi-gazdasági státusza rosszabb az össztársadalmi átlagnál, ezt a csoportot jelentős mér- 
tékben érinti a szegénységi kockázat (Kozma \& mtsai, 2020; Központi Statisztikai Hivatal, 2015, 2018; Nagy, 2011). Vagyis, miközben a potenciális felhasználók száma - és szükségleteik mértéke - jelentős, sőt, folyamatosan növekszik, valamint egyre több és újabb támogató technológiai megoldás jelenik meg a piacon, a végfelhasználók vásárlóereje nincs egyensúlyban az árakkal és egyéb kapcsolódó költségekkel. Természetesen, piaci áron, bárki bármilyen terméket vásárolhat. Ám, ha figyelembe vesszük, hogy a potenciális felhasználók célcsoportja milyen társadalmi-gazdasági helyzetben van, belátható az igény valamilyen támogatási rendszer müködtetésére.

Anélkül, hogy mélyebben beleásnánk magunkat a tb-támogatott segédeszközök nemzeti listájának tartalmába, fontos látni, hogy a hozzáférési korlát abban az esetben is fennállna, ha a listán az egyébként elavult szabvány mentén a piacon elérhető lehető legmodernebb és leginkább jól használható eszközök szerepelnének. A tb-támogatott listáról azonban az önálló életvitel legfontosabb dimenzióira reagáló eszközök hiányoznak: nincs lehetőség oktatási és képzési célú segédeszközök (például iskolai tárgyak tanítását segítő vagy művészeti készségek elsajátítását könnyítő eszközök); tárgyak mozgatását és működtetését segítő eszközök (például speciális fogók kézfunkciókiesésben érintetteknek); környezeti adaptáló berendezések (például speciális levegőtisztító berendezések); sem kikapcsolódáshoz használt eszközök (például kertészkedési vagy kisállattartási segédeszközök) igénylésére, mivel ezek a termékcsoportok a 2002-es szabványnak még nem voltak a részei. A legnagyobb hiátust mégis valószínüleg a munkavégzéshez használható segédeszközök föcsoportjának elmaradása okozza, köztük a munkakörnyezetet adaptáló (például billenő asztal, állítható szék), illetve a munkavégzést megkönnyítő (például adaptált mozgató eszközök, számítógépek) eszközökkel és technológiával. Az ISO:9999 szabvány 2007-es felülvizsgálata a kommunikációs eszközöket érintette a legjelentősebben, köszönhetően az infokommunikációs technológiák térnyerésének (Bougie, 2008). E főcsoport kódjai megváltoztak, lehetőséget adva az IKT és AAK eszközök bekerülésének. A magyar listán a beszédfogyatékosságban érintetteknek szinte nincs elérhető modern kommunikációs eszköz, nincsenek kommunikátorok, annak ellenére, hogy 2017-ben az Alapvető Jogok Biztosa vizsgálatában megállapította, hogy ezek használatának jelentős hatása van az érintettek életminőségének javítására.

2013-ban az ENSZ Közgyűlése kiemelt globális céllá emelte a segédeszközök hozzáférhetőségének javítását, ami ezzel bekerült a 2030-ig megvalósítandó Fenntartható Fejlesztési Célok közé (lásd erről bővebben Tebbutt és mtsai, 2016). 2013 szeptemberében az ENSZ Közgyülésének magas szintü tanácskozásán az Egészségügyi Világszervezet felkérést kapott, hogy fejlesszen ki és koordináljon egy olyan globális kezdeményezést, amely a tagállamokat segíti abban, hogy felismerjék a kötelezettségeiket a támogató-segítő eszközök és technológia hozzáférhetőségének biztosításában. 2014-ben a WHO létrehozta a Global Cooperation on Assistive Technology (GATE) munkacsoportot, nemzetközi szervezetekkel, donor intézményekkel, szakmai szervezetekkel, akadémiai intézményekkel és felhasználókkal együttműködésben. A munkacsoport célja, hogy javítsa a „magas minőségű és megfizethető támogató eszközök" globális hozzáférhetőségét (GATE | Global Cooperation on Assistive Technology, é.n.).

A WHO GATE munkacsoport 2016-ban a világ minden részéröl kért fel szakértőket és érintetteket, hogy segítsék egy olyan lista létrejöttét, ami az ötven legfontosabb olyan segédeszközt tartalmazza priorizált sorrendben (lásd 2. táblázat), 
amelyeket a világ valamennyi országában feltétlenül szükséges (volna) biztosítani az önálló életvitel támogatásához (Egészségügyi Világszervezet, 2016). Továbbra is anélkül, hogy részleteznénk a magyar támogatott GYSE listát, az látszik, hogy a prioritási listán szereplő eszköztípusoknak kevesebb mint a fele van jelen a magyar támogatott GYSE listán. (A listán nem szereplő eszközökhöz egyedi támogatás formájában, a pénzügyi keret kimerüléséig kérvényezhető hozzájárulás, ennek folyamatára ebben az írásban részletesen nem térek ki.)

\begin{tabular}{|c|c|c|}
\hline 1) & Vészjelzők (fény-, hang-, rezgés-alapú) & 1. Digitális személyi asszisztens \\
\hline 2) & $\begin{array}{l}\text { Hanglejátszók hangoskönyv (DAISY) lejátszási } \\
\text { lehetöséggel }\end{array}$ & 2. Személyes vészjelző készülékek \\
\hline 3) & Braille kijelzővel ellátott jegyzetelö készülék & 3. Gyógyszeradagolók \\
\hline 4) & Braille írógépek és tartozékaik & 4. Antidekubitusz, memória párnák \\
\hline 5) & Botok, járóbotok & 5. Antidekubitusz, memória matracok \\
\hline 6) & Székek (zuhanyzáshoz, fürdéshez, toaletthez) & 6. Alsó végtag protézisek \\
\hline 7) & Feliratokat hozzáférhetővé tévő eszközök & 7. Hordozható rámpák \\
\hline 8) & Dongaláb-rögzítők & 8. Hangfelvevők \\
\hline 9) & Kommunikációs táblák, könyvek, kártyák & 9. Rollátorok \\
\hline 10) & Kommunikációs szoftverek & 10. Képernyőolvasók \\
\hline 11) & Mankók (könyök, hónalj) & 11. Könnyen kezelhetö mobiltelefonok \\
\hline 12) & Kommunikátorok siketvak embereknek & $\begin{array}{l}\text { 12. Szemüvegek (gyengénlátáshoz, } \\
\text { rövidlátáshoz, távollátáshoz, szürőkkel és } \\
\text { védőkkel) }\end{array}$ \\
\hline 13) & Esésérzékelők & 13. Szabályozható állitó készülékek \\
\hline 14) & Gesztusokat, jelelést hanggá alakító eszközök & $\begin{array}{l}\text { 14. Gyógycipők (diabétesz, neuropátia, } \\
\text { ortopéd) }\end{array}$ \\
\hline 15) & GPS helyzetmeghatározók & 15. Idömenedzsment termékek \\
\hline 16) & Kapaszkodók, korlátok & 16. Hordozható közlekedési segédeszközök \\
\hline 17) & (Digitális) hallókészülékek és elemek & 17. Triciklik \\
\hline 18) & Indukciós hurok / FM rendszer & 18. Videó kommunikációs eszközök \\
\hline 19) & Inkontinencia termékek, nedvszívó anyagok & 19. Járókeretek \\
\hline 20) & Billentyüzet és egér szoftverek & 20. Órák (Beszélő, tapintható) \\
\hline 21) & Digitális kézi nagyítók & 21. Aktív kerekesszékek \\
\hline 22) & Optikai nagyítók & $\begin{array}{l}\text { 22. Mechanikus kerekesszékek segitői } \\
\text { kontrollal }\end{array}$ \\
\hline 23) & Alsó végtag ortézisek & $\begin{array}{l}\text { 23. Mechanikus kerekesszékek, törzs/nyak/ } \\
\text { fejtámasszal }\end{array}$ \\
\hline 24) & Gerinc ortézisek & 24. Elektromos kerekesszékek \\
\hline 25) & Felső végtag ortézisek & 25. Fehérbotok \\
\hline
\end{tabular}

2. táblázat. Az Egészségügyi Világszervezet listája a legfontosabb támogató eszközökröl és technológiáról, prioritási sorrendben

Forrás: Egészségügyi Világszervezet, 2016. A magyar listán nem szereplő eszközök dőlt betűvel szedve, 2020. szeptemberi állapot alapján, http://sejk.oep.hu/. A szerző fordítása. A fordításhoz nyújtott segítségükért a szerző köszönetét fejezi ki az ELTE BGGYK oktatóinak. 
A magyar listás gyógyászati segédeszközökröl összefoglalóan az állapítható meg, hogy elsősorban biológiai szükségletekre reagálnak, és hiányoznak a társadalmi részvétel (foglalkoztatási részvétel, oktatási részvétel, közösségi részvétel) céljából használatos eszközök és technológiai megoldások, ami hasonlóan az inkonzisztens fogalomhasználathoz a rendszer elavultságát jelzi.

\section{KONKLÚZIó}

A támogató technológia kifejezés és annak tartalma, az operacionalizálást segítő nemzetközi ISO:9999 szabvány aktuális változatának használata nem terjedt el Magyarországon, ami a szolgáltatás szintjén is elavultságot és a hozzáférés korlátozottságát eredményezi. A fogalom eközben a felhasználók és a szakemberek szóhasználatába se épült be, amit alapvetően információs aszimmetriaként értékelhetünk. Habár Magyarországnak - mint a fogyatékosságügyi ENSZ egyezményt ratifikáló valamennyi országnak - vannak vállalt kötelezettségei a támogató technológia hozzáférhetöségének biztosítását tekintve, ideértve többek között az eszközökről való információáramlás biztosítását is, ezek teljesítésében elmaradás látszik. Ez az írás a támogató technológiát és az ahhoz való hozzáférést kizárólag az eszközök felöl közelítette, nem érintette a felhasználók és az elosztásban részt vevő egyéb szereplők (például szakemberek, forgalmazók, gyártók) élményeit, gyakorlati tapasztalatait, és az eszközhöz jutás folyamatának egyéb aspektusait sem. Annak, hogy hiányoznak a listáról olyan eszközök, amelyek bizonyos fogyatékosságok esetén elengedhetetlenek lennének az önálló életvitelhez, sőt, az alapvető jogok gyakorlásához, nem kizárólag az az oka, hogy az elosztás egy elavult szabvány kódrendszere mentén valósul meg, a rendszer müködése ennél jóval bonyolultabb. Az viszont bizonyos, hogy amíg a jogalkotó nem követi a nemzetközi változásokat, addig a listán föcsoport hiányában nem szereplő eszközökhöz a felhasználók aligha jutnak hozzá, de legalábbis egyenlötlenség keletkezik azok között, akik piaci alapon (vagy személyes kapcsolati hálójukon keresztül segítséggel, külföldi forrásból, esetleg a másodlagos piacról használtan) meg tudják venni az eszközöket és azok között, akiknek ehhez nem áll rendelkezésükre elegendő (erő)forrás (Menich, 2016).

Mindezek következményeképp azok a végfelhasználók járnak rosszul, akik társadalmi státusukat tekintve rosszabb helyzetben vannak, mint a fogyatékosságban nem érintett emberek, és akiknek a szolgáltatásokhoz - köztük segédeszközökhöz - való hozzáférése számos strukturális korlát okán, megannyi ponton falakba ütközik. A modern, magas minőségű támogató eszközökről és technológiáról való információk beépítésének a köztudatba, a szakmai szóhasználatba és a szolgáltatási struktúrába kiemelt jelentősége volna a felhasználóik életminőségének javítása szempontjából.

\section{Irodalom}

1997. évi CLIV. törvény az egészségügyről

1998. évi XXVI. törvény a fogyatékos személyek jogairól és esélyegyenlőségük biztosításáról 2006. évi XCVIII. törvény a biztonságos és gazdaságos gyógyszer- és gyógyászatisegédeszköz-ellátás, valamint a gyógyszerforgalmazás általános szabályairól 
AAATE (2003). AAATE position paper. A 2003 view on Technology and Disability. Association for the Advancement of Assistive Technology in Europe.

Andrich, R., Mathiassen, N.-E., Hoogerwerf, E. J., \& Gelderblom, G. J. (2013). Service delivery systems for assistive technology in Europe: An AAATE/EASTIN position paper. Technology and Disability, 25.3:127-146. https://doi.org/10.3233/TAD-130381

Bougie, T. I. (2008). ISO 9999 Assistive Products for Persons with Disability: Classification and Therminology. In Helal, A., Mokhtari, M. \& Abdulrazak, B. (eds.), The Engineering Handbook of Smart Technology for Aging, Disability, and Independence. John Wiley \& Sons. https://doi.org/10.1002/9780470379424.ch6

Cozza, M., Crevani, L., Hallin, A., \& Schaeffer, J. (2019). Future ageing: Welfare technology practices for our future older selves. Futures, 2019.109:117-129. https://doi.org/10.1016/j. futures. 2018.03.011

de Witte, L., Steel, E., Gupta, S., Ramos, V. D. \& Roentgen, U. (2018). Assistive technology provision: Towards an international framework for assuring availability and accessibility of affordable high-quality assistive technology. Disability and Rehabilitation: Assistive Technology, 13.5:467-472. https://doi.org/10.1080/17483107.2018.1470264

Egészségügyi Világszervezet (é.n.). Assistive technology. https://www.who.int/news-room/ fact-sheets/detail/assistive-technology Letöltés ideje: 2019.01.15.

Egészségügyi Világszervezet (2016). Priority assistive products list (WHO/EMP/PHI/2016.01). Egészségügyi Világszervezet. https://apps.who.int/iris/rest/bitstreams/920804/retrieve Letöltés ideje: 2019.01.15.

Egészségügyi Világszervezet (2018). Improving access to assistive technology (Report by the Director-General A71/21). Egészségügyi Világszervezet.

GATE | Global Cooperation on Assistive Technology (é. n.). WHO. http://www.who.int/phi/implementation/assistive_technology/en/ Letöltés ideje: 2019.01.16.

Goodley, D. (2019). Fogyatékosságtudomány. ELTE Bárczi Gusztáv Gyógypedagógiai Kar, Budapest.

Gupta, N., Castillo-Laborde, C., \& Landry, M. D. (2011). Health-related rehabilitation services: Assessing the global supply of and need for human resources. BMC Health Services Research 11.1:276. https://doi.org/10.1186/1472-6963-11-276

International Standards Organisation. (2016). ISO 9999:2016.

Khasnabis, C., Mirza, Z., \& MacLachlan, M. (2015). Opening the GATE to inclusion for people with disabilities. The Lancet, 386.10010:2229-2230.) https://doi.org/10.1016/S01406736(15)01093-4

Kozma Á., Petri G. \& Bernát A. (2020). Kiszolgáltatottság és stagnálás: Fogyatékos emberek társadalmi helyzete a 2010-es években. In Kolosi T., Szelényi I., Tóth I. Gy. (szerk.), Társadalmi Riport 2020. TÁRKI, Budapest. 381-403.

Könczei Gy. \& Kálmán Zs. (2002). A Taigetosztól az esélyegyenlöségig. Osiris Kiadó, Budapest.

Központi Statisztikai Hivatal (2015). A fogyatékossággal élök helyzete és szociális ellátásuk (2011. évi népszámlálás). Központi Statisztikai Hivatal, Budapest.

Központi Statisztikai Hivatal (2018). Mikrocenzus 2016. A fogyatékos és az egészségi ok miatt korlátozott népesség jellemzői (KSH). Központi Statisztikai Hivatal, Budapest.

MacLachlan, M. (2018). Access to Assistive Technology, Systems Thinking, and Market Shaping: A Response to Durocher et al. Ethics \& Behavior, 29.3:196-200. https://doi.org/10. 1080/10508422.2018.1447382

Menich N. (2016). Kit támogat a támogató technológia? A fogyatékossággal élő emberek segédeszközökhöz való hozzáférésének kérdései Magyarországon. Esély, 2016.5:52-71.

Nagy Z. É. (szerk.) (2011). Az akadályozott és az egészségkárosodott emberek élethelyzete Magyarországon. Nemzeti Család- és Szociálpolitikai Intézet, Budapest.

Nemzeti Egészségbiztosítási Alapkezelö (2021). http://www.neak.gov.hu/ Letöltés ideje: 2021.04.30.

Tebbutt, E., Brodmann, R., Borg, J., MacLachlan, M., Khasnabis, C., \& Horvath, R. (2016). Assistive products and the Sustainable Development Goals (SDGs). Globalization \& Health, 12.79. https://doi.org/10.1186/s12992-016-0220-6

Tóth M. \& Mischinger, G. (2012). Támogatóeszköz-, támogatótechnológiai, gyógyászatisegédeszköz-adatbázisok a mozgáskorlátozott emberek rehabilitációjának szolgálatában. MEREK (Guruló Projekt), Budapest.

Weinhoffer J. (2017). A katona-egészségügy szerepe a rehabilitáció XX. századi fejlödésében. (Doktori értekezés.) Nemzeti Közszolgálati Egyetem Hadtudományi Doktori Iskola, Budapest. 


\section{A segítőkutyák valóban szinte „bárhová” elkísérhetik gazdáju- kat? Közszolgáltatást nyújtó in- tézmények képviselőivel végzett interjús vizsgálat eredményei}

Segítőkutya-gazdák gyakran szembesülnek azzal, hogy - a hatályos jogszabályi rendelkezések ellenére - speciálisan képzett négylábú társuk jelenléte miatt megtagadják számukra valamely (köz)szolgálatás igénybevételét. A tanulmány - segítőkutya-gazdák körében végzett, szélesebb spektrumú kutatások tanulságaira támaszkodva közszolgáltatók képviselőivel készült 15 interjúbeszélgetést mutat be, melyek tartalmi kiértékelése MAXQDA szövegelemző szoftver támogatásával történt. A vizsgálat feltárt néhány, a konfliktushelyzetek hátterében megbúvó „sokrétü” okot is. A tanulmány, a mindenki által elfogadható megoldás előmozdítása érdekében, javaslatcsomaggal és annak realitását alátámasztó hatásútvonal-térképpel zárul. A szerzőre erősen hatott az inkluzív (emancipatív) szemléletmód, ugyanis maga is érintett személy (mindennapjait hallássérült-segítő kutya könnyíti meg), így személyes tapasztalatait is megosztja.

Kulcsszavak: segítőkutya, közszolgáltatás, egyenlő esélyü hozzáférés, inkluziv kutatások

\section{BEVEZETÉS - ELŐZMÉNYEK}

A tanulmányban ismertetett kutatás témáját saját élethelyzetemböl kiindulva választottam. Súlyos hallássérüléssel születtem. Szabadidőmben a NEO Magyar Segítökutya Közhasznú Egyesület munkáját segítem önkéntesként és alapító tagként, programvezetőként (NEO MSKKE, 2021). Mindennapjaimban nagy szerepet játszik a két vizsgázott hangjelző kutyám: Kuku már idős, nyugdíjas hallássérült-segítő kutya, az ő utódja a fiatalabb Mák. Éjszaka, amikor nem viselem a hallásjavító készüléket, különösen felértékelödik a fizikai segítségnyújtásuk (hangok és zajok jelzése), azonban napközben is sokat jelent számomra a jelenlétük (például sosem érzem magam magányosnak, jelenlétük sokszor feloldja a kommunikációs nehézségek által okozott zavartságot a halló emberekben is) (Loványi, 2018a; Loványi \& Perlusz, 2016). Az egyesületi munkámon keresztül többféle speciálisan képzett (például vakvezető, rohamjelző, mozgássérült-segítő, személyi segítő) kutya munkájába és - a pozitív élmények mellett - más gazdák nehézségeibe is beleláthattam (Eddy és mtsai, 1988; Hoffman, 2013; Lane és mtsai, 2016; Martinez \& Barns, 2013; Rintala és mtsai, 2008; Sanders, 2000; Viau és mtsai, 2010). A felmerülő problémák egyik forrása, hogy hiába tenné lehetővé a fogyatékos személyek jogairól és esélyegyenlöségük biztositásáról szóló 1998. évi XXVI. törvény (továbbiakban: 1998-as esélyegyenlöségi törvény) illetve a segítő kutya kiképzésének, vizsgáztatásának és alkalmazhatóságának szabályairól szóló 27/2009. (XII. 3.) SZMM rendelet (továbbiakban: 2009-es rendelet) számunkra, hogy bevihessük vizsgázott négylábú segítőtársunkat a mindenki 
előtt nyitva álló területekre (például bevásárlóközpont, tömegközlekedési eszköz, múzeum), sok esetben szembesülünk akadállyal a (köz)szolgáltatások igénybevétele során. A probléma fennállását és jelentőségét jelzi az is, hogy a 2009-es rendelet megjelenése óta az alapvető jogok biztosa és az Egyenlő Bánásmód Hatóság is többször foglalkozott a kérdéssel (például az alapvető jogok biztosának jelentése az AJB 2663/2013. és AJB 735/2017. számú ügyben, illetve az Egyenlő Bánásmód Hatóság eljárása az EBH/38/2018-as esetben), pedig feltehetőleg sok incidens nem is került bejelentésre.

Segítőkutyát alkalmazó személyek körében végzett korábbi kutatásaim megerősítették Kukuval és Mákkal átélt tapasztalataimat.

1. Kérdőives és interjús vizsgálatok eredményei szerint más vizsgázott segítőkutya-gazdák is az alapfeladatokon (például hangok jelzésén) túl számos - a társadalmi beilleszkedést támogató - járulékos hatást tulajdonítottak segítőkutyájuknak (például kommunikáció, közlekedés, részvétel közösségi programokban). Tehát a segítőkutya olyan rehabilitációs lehetőség, amely előmozdítja gazdája fizikális, pszichés/mentális, szociális jóllétét (Loványi, 2020a).

2. Nemzetközi kvantitatív felmérésem során a megkérdezett segítőkutya-gazdák 90,7 százaléka nyilatkozta azt, hogy volt már olyan tapasztalata, hogy a segítőkutyája jelenléte miatt megtagadtak tőle egy közszolgáltatást (Loványi, 2018b, 2020b).

3. A segítőkutyák elfogadottsága terén a magyar gazdák mindössze 62,9 százaléka látott javulást a kutatást megelőző három évben. Véleményük szerint a segítőkutyával történő egyenlő esélyü hozzáférés akadályozottságának hátterében többféle ok húzódhat meg (például a szolgáltatást nyújtó intézmények üzemeltetői nem ismerik a segítőkutyákkal kapcsolatos jogszabályi hátteret, nincs közvetlen tapasztalatuk a fogyatékossággal élő személyekre vonatkozóan, egyes biztonsági örök visszaélnek a „hatalmukkal”, kutyákhoz való negatív viszonyulás, empátia hiánya) (Loványi, 2019).

Feltehetőleg saját érintettségemnek köszönhetően, a segítőkutya-gazdákat könynyen el tudtam érni, és szívesen is végeztem ilyen témájú kutatásokat. Ugyanakkor a lehető legobjektívebb megítélés érdekében fontosnak tartottam, hogy ne csak az „én világomat” mutassam be, hanem a „másik oldalt”, a közszolgáltatók képviselőinek véleményét is kikérjem. Első körben 15, mindenki előtt nyitva álló, szolgáltatást nyújtó intézmény üzemeltetőjével/vezetőjével/dolgozójával készítettem interjúkat (2018. február és április között); ennek tapasztalatairól számolok be ebben a tanulmányban.

Erősen hatottak rám a 1990-es évek óta jelenlévő inkluzív megközelítések, melyek támogatják a fogyatékossággal élő és a nem fogyatékos partnerek egyenrangú együttműködését az oktatásban, illetve kutatásokban. Az inkluzív szemléletmód egyik alappillére az emancipatív paradigma. Ebben az esetben megfelelő végzettséggel rendelkező, fogyatékos szakemberek irányítják az egész kutatási folyamatot. Mivel ezen irányzatok tudományos szinten fontosnak tartják a személyes vonulat bemutatását, én is beszámolok az interjúk szervezése és a beszélgetések alatt szerzett benyomásaimról (Bergold \& Thomas, 2010; Marton, 2014; Mercer, 2002; Katona és mtsai, 2019). 


\section{SZOLGÁLTATÁSI TERÜLETEN DOLGOZÓ INTERJÚALANYOK KIVÁLASZTÁSA ÉS A BESZÉLGETÉSEK KÖRÜLMÉNYEI}

A mintavétel segítőkutya-gazdák közremüködésével történt: először őket kérdeztem meg, hogy van-e egy éven belül szerzett tapasztalatuk olyan (köz)szolgáltatóval, ahova probléma nélkül beengedték őket - vagy éppen nem, a jogszabályok által meghatározott lehetőségek ellenére. Az így kialakított listán szereplő helyszíneket kértem fel interjúra. A segítőkutya-gazdák megfogalmazták azt is, hogy fontos számukra, hogy a mentőszolgálat, a tűzoltóság és a rendőrség is tisztában legyen a segítőkutyák jogaival, így őket is megkerestem.

A végleges mintát és az intézmények kiválasztásának szempontjait a következő táblázat szemlélteti.

\begin{tabular}{|c|c|c|}
\hline $\begin{array}{l}\text { A JOGSZABÁLYBAN } \\
\text { SZEREPLÓ KATEGÓRIÁK }\end{array}$ & $\begin{array}{l}\text { PoZitív ÉLMÉNY A SZOLGÁLTATÁS } \\
\text { IGÉNYBEVÉTELEKOR }(+)\end{array}$ & $\begin{array}{l}\text { FELMERÜLT AKADÁLY A SZOLGÁLTATÁS } \\
\text { IGÉNYBEVÉTELEKOR (-) }\end{array}$ \\
\hline KÖZLEKEDÉS & közlekedési vállalat & légitársaság \\
\hline Nyilatkozó & járművezető & pilóta \\
\hline $\begin{array}{l}\text { Segítőkutya-gazdák } \\
\text { beszámolója }\end{array}$ & $\begin{array}{l}\text { „...a buszvezető csak tágra tárt } \\
\text { szemekkel nézett rám, amikor } \\
\text { mondtam, hogy a segítőkutyákra } \\
\text { nem kell szájkosár. Elnézést kért, } \\
\text { majd kedvesen kérdezgetett. } \\
\text { Látszott, hogy komolyan érdekli } \\
\text { a segítőkutyák világa.” }\end{array}$ & $\begin{array}{l}\text { „Egy külföldi repülötéren a becsekkolás után } \\
\text { éppen indultunk a biztonsági ellenőrzéshez, } \\
\text { amikor hirtelen odajött hozzánk egy marcona } \\
\text { kinézetü biztonsági szolgálatos hölgy, és } \\
\text { szigorúan közölte, hogy azonnal álljunk ki } \\
\text { a sorból, a gépre csak vakvezető kutya mehet } \\
\text { fel. Úgy bánt velünk a hölgy, mintha bünözők } \\
\text { lennénk, minden tekintet ránk szegeződött, } \\
\text { igen kellemetlen érzés volt. Mi mondtuk, } \\
\text { hogy engedélyünk van mozgássérült- } \\
\text { segítő kutyával is utazni a járaton, elöre } \\
\text { leegyeztettük a légitársasággal, írásos } \\
\text { visszaigazolásunk is van róla... Telefonálgatás } \\
\text { haza az ügyfélszolgálatra, ahol végül } \\
\text { mondták, hogy ezzel a kutyával biztos nem } \\
\text { utazhatunk. Kérdeztük, hogy akkor egyáltalán } \\
\text { miért hoztak ki külföldre? Az volt a válasz, } \\
\text { hogy akkor hibázott a légitársaság, de most } \\
\text { nem fog... Hatalmas pánik és kétségbeesés } \\
\text { lett úrrá rajtunk, } 1400 \text { kilométerre voltunk az } \\
\text { otthonunktól.” }\end{array}$ \\
\hline ÜZLET & 1. számú kereskedelmi lánc & 2. számú kereskedelmi lánc \\
\hline Nyilatkozó & áruházvezető & áruházvezető \\
\hline $\begin{array}{l}\text { Segítőkutya-gazdák } \\
\text { beszámolója }\end{array}$ & $\begin{array}{l}\text { „Jött a biztonsági őr, amikor } \\
\text { mondtam, hogy ő egy segítőkutya, } \\
\text { mosolyogva továbbengedett, sőt } \\
\text { a rádión szólt a kollégáinak is, } \\
\text { ezután senki tudomást se vett } \\
\text { rólunk.” }\end{array}$ & $\begin{array}{l}\text { „...és akkor vásárlás közben a biztonsági őrtől } \\
\text { kezdve a hentesen keresztül a pénztárosig } \\
\text { mindenki elmondta, hogy ide tilos élőállatot } \\
\text { - még segítőkutyát se lehet - behozni. } \\
\text { Ez volt az életem legidőigényesebb vásárlása." }\end{array}$ \\
\hline SZÁLLÁSHELY & 1. számú hotel & 2. számú hotel \\
\hline Nyilatkozó & menedzser & vezető \\
\hline $\begin{array}{l}\text { Segítőkutya-gazdák } \\
\text { beszámolója }\end{array}$ & $\begin{array}{l}\text { „A szállodalánc több hotelében } \\
\text { voltunk már. Segítőkutya } \\
\text { ingyenesen szállhat meg, sőt } \\
\text { az étterembe is bemehet, és } \\
\text { egy tál vízről is gondoskodik } \\
\text { a személyzet. Nagyon kedvesek.” }\end{array}$ & $\begin{array}{l}\text { „Egy rendezvény megtartásához kértem } \\
\text { árajánlatot a hoteltöl, egy nagyobb csoport } \\
\text { számára, egy-két vizsgázott segítókutyával } \\
\text { érkező résztvevővel. Jelezték, hogy } \\
\text { a kutyákat be lehet vinni az étterembe, de } \\
\text { a szobákba már nem. Mivel az egyik gazda } \\
\text { távolabbról jött és szeretett volna ott aludni, } \\
\text { végül az egész program meghiúsult.” }\end{array}$ \\
\hline
\end{tabular}


A JOGSZABÁLYBAN

SZEREPLÖ KATEGÓRIÁK

\section{USZODA}

Nyilatkozó

Segítőkutya-gazdák

beszámolója

igazgató

ÁLLATKERT
Nyilatkozó
Segítőkutya-gazdák
beszámolója

KÓRHÁZ
Nyilatkozó
$\begin{aligned} & \text { Segítőkutya-gazdák } \\ & \text { beszámolója }\end{aligned}$
+ ÖRZÖ-VÉDŐ, MENTÉST
VÉGZŐ SZOLGÁLAT

Nyilatkozó

Segítőkutya-gazdák beszámolója

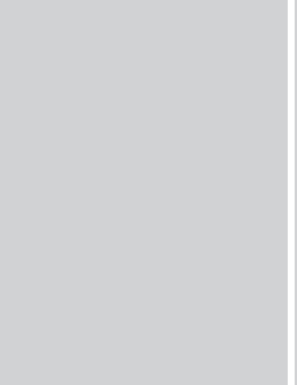

sebészorvos

„Képzeld, a váróterem falára

\section{rendörség}

\section{tűzoltóság}

Nyilatkozó

Segítőkutya-gazda beszámolója végzett interjúkhoz
Pozitív Élmény a szolgáltatás IGÉNYBEVÉTELEKOR (+)

1. számú fürdő

„A baráti társasággal wellness-elni mentünk. Azt gondoltam, hogy fürdőbe segítőkutyával bejutni lehetetlen vállalkozás, de azért érdeklődtem emailben. A válasz felülmúlta minden várakozásomat, ezt írták: „Ahogyan a törvény is leírja, segítőkutyájával együtt is látogathatja a fürdő területét. Szeretettel várjuk Önöket." A helyszínen is megleptek minket, nekem (és a kutyámnak) nem kellett belépőt fizetni, és kérdezgettek, hogy mivel tudják még kényelmesebbé tenni az ott tartózkodásunkat."

\section{1. számú állatkert}

szakmai vezetö, állatorvos

„Egy csapattal voltunk az Állatkertben. Nem is szóltak a segitökutyám miatt, nem is kérdeztek semmit, gond nélkül bemehettünk. A kutyám is szépen viselkedett, csak nézte az állatokat. A látogatók is dicsérték, hogy milyen okos."

\section{1. számú kórház} kifüggesztett házirendben is olvastam, hogy segítőkutya bejöhet!"

rendör

\section{„Egyszer egy férfi}

a bevásárlóközpontban úgy beszorított minket a sarokba hogy ki kellett hívni a rendőrséget. Öt percen belül ott voltak, két fiatalember jött ki. Kérdezték, hogy mi a probléma. Akkor mondtam, hogy ő segitőkutya, itt vannak a papírok, nekünk jogosultságunk van a kutyával ide belépni és innen nyugodtan távozni, vásárolni. Akkor így szólt a rendör annak az úrnak: „Kénytelen vagy öket beengedni, mert jogszabály előírja." Így elintézhettük a dolgunkat."

FELMERÜlt AKADÁLY A SZOLGÁLTATÁS IGÉNYBEVÉTELEKOR (-)

2. számú fürdő

igazgató

„Felhívtam a fürdőt, hogy pár nap múlva szeretnék menni segítőkutyával. Azt válaszolták, hogy kutyával nem lehet jönni. Hivatkoztam a rendeletre, le is diktáltam a számát, Kértem, hogy nézzenek utána másnapra és hívjanak vissza. Amikor visszakérdeztem a jogszabályra, kiderült, hogy fel se írták először. A következő nap nem telefonáltak, végül én hívtam újra őket. Vezetővel beszéltem, aki azt mondta, hogy mehetünk, de végig kísérgetni fog minket valaki. Kértem, hogy ezt ne tegyék, amit sértésnek vettek. Eleinte állandóan rádióztak, hogy mit csinál a segítőkutyám meg hol vagyunk éppen, de végül ezt abbahagyták, mivel látták, hogy csak ott fekszik, ahol hagyom."

\section{2. számú állatkert}

igazgató

„Az egyik állatkertben a bejárat közelében külön kennelt építettek a segítőkutyáknak. A családi kirándulás során a hozzám nagyon kötődö segitőkutyámat nem szerettem volna oda bezárni, a kánikula miatt a kocsiban nem hagyhattam. Így inkább kihagytuk a tervezett programot. Ennyit erröl, hogy a jogszabály is külön kiemeli, hogy állatkertbe bevihetö segitőkutya."

\section{2. számú kórház} sebészorvos

„Elöre megkérdeztem, és azt mondták, hogy csak a kertbe vihetem be a segítökutyát, az épületbe nem."

\section{mentőszolgálat}

mentőtiszt, igazgató

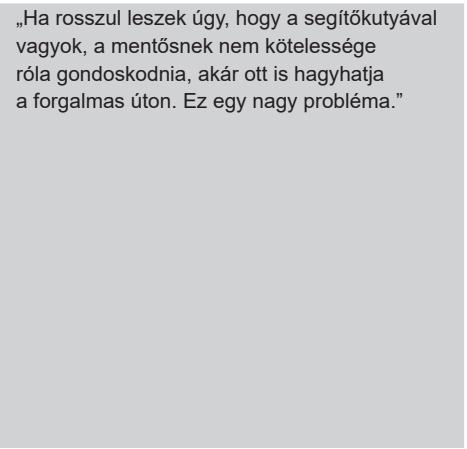

nyugalmazott városparancsnok

„Nálunk tüz ütött ki. Belegondoltam, hogy ha nekem nem lenne kutyám, egyedül vagyok, hallókészülékem nincs a fülemben, mert ugye éjfél után történt, hiába dörömböl a tűzoltó, nem is hallom."

1. táblázat. Mintavételi szempontok a (köz)szolgáltatást nyújtó intézmények képviselőivel 
Az alábbiakban kiemelek néhány előzetes speciális megfontolást, melyekre tekintettel voltam az interjúk során.

1. A szolgáltatást nyújtó intézményekben folytatott interjúk egy részére a segítőkutyámat is vittem magammal: egyrészt a fogadtatás is hasznos vizsgálati tapasztalat volt, másrészt szemléletformálás céljából. Ugyanis azt gondoltam, hogy segítőkutyám jelenléte jelentősen befolyásolhatja a beszélgetések kimenetelét (akár pozitív, akár negatív irányban), ezért csak a találkozók felére mentem segítőkutyával - hogy tesztelhessem ezt az elöfeltevésemet is. Ezeket a helyszíneket a szervezés tapasztalatai (például előzetes reakciók, intézményektől kapott visszajelzések) alapján választottam ki, természetesen az interjúalanyokkal egyeztetve (senkit sem ért váratlanul a segítőkutyám csatlakozása).

2. Az esetleges kommunikációs akadályok kiküszöbölése érdekében szájról olvasási tolmács is elkísért engem, hiszen hibás kiejtésem nehezebben érthető lehet, illetve nekem is lehetnek szájról olvasási problémáim (például szakállas beszélgetötárs esetében). Nagy örömömre, általában nem volt szükség a tolmács közremüködésére, végig én koordináltam a beszélgetéseket, csak egy-két „elakadás átbillentésében” kértem a segítségét.

3. Az interjúkról felvétel készült, a hanganyagot a tolmács gépelte le számomra, mivel a hallássérülésem miatt nem tudtam visszahallgatni azokat. Az artikulációs tolmácsokat is titoktartás kötelezi, ami fontos szempont a kutatásoknál (Magyar Jelnyelvi Tolmácsok Etikai Kódexe, 2014).

4. Különösen figyeltem arra, hogy a kapcsolatfelvételnél tágabb témakört adjak meg (például a segítőkutyák elfogadottságának vizsgálata), hogy a szolgáltatók munkatársai ne tudjanak előzetesen felkészülni a beszélgetésre, így a valós helyzetet tudjam feltárni. Továbbá rugalmasan reagáltam az interjúalanyok elbeszéléseire, ez az intézmények eltérő tevékenységi típusa miatt is fontos volt.

5. Az interjúk végén megajándékoztam a beszélgetőtársaimat Kuku és barátai - Ismerjük meg közösen a segítőkutyák világát! című mesekönyvemmel. Ezáltal azok is betekintést kaphattak a segítőkutyák munkájába és a jogszabályi háttérbe, akik még nem találkoztak ezzel a területtel (Loványi, 2015).

A fentiekben részletezett szempontokon túl természetesen az interjús vizsgálatok során felmerülő módszertani ajánlásokra és kutatásetikai elvárásokra is figyelemmel voltam (Babbie, 2008; ELTE BGGYK TUKEB, 2020; Seidman, 2002; Szokolszky, 2004), valamint az ELTE Bárczi Gusztáv Gyógypedagógiai Kar Tudományos és Kutatásetikai Bizottsága is jóváhagyta a kutatási tervemet (engedélyszám: KEB/2017/015).

\section{SZERVEZÉSI ÉS SZEMÉLYES TAPASZTALATOK}

Néhány (köz)szolgáltatást nyújtó helyszín dolgozóját meglehetősen nehéz volt motiválni, még az anonimitás biztosítása mellett is. Meglátásom szerint ennek az én fogyatékosságom, a számukra ismeretlen területtől való félelem lehetett az oka, vagy a felkért intézmények képviselői úgy vélték, hogy érzékeny pontra tapintottam 
rá (esélyegyenlőség). Az interjúk szervezése hosszú időt vett igénybe, illetve a segítőkutyám fogadtatása is eltérő volt. Néhány emlékezetes esetet ki is emelek:

1. Az egyik helyszín esetében úgy adta a jóváhagyását az igazgató, ha a vezető beosztású munkatársával készült interjú legépelt változatát elküldöm neki egyeztetésre. Ezt meg is tettem, ő utólag korrektúrázta is kollégája beszámolóját. Áttekintve a módosításokat, úgy döntöttem, hogy bent hagyom ezeket a végső változatban, mert - bár több javítás történt - azok kutatásom témáját nem befolyásolták, inkább a kiegészítő információkat érintették.

2. Egy szervezetnél meghiúsult az interjú, ahol egy tisztviselőjükkel szerettem volna beszélgetni. A közel félévig tartó belső egyeztetésük után elkészült titoktartási szerződésben olyan feltételeket határoztak meg, amelyek kivitelezhetetlenné tették volna az interjút. Például nem készülhetett volna hanganyag, csak írásbeli emlékeztető (hallássérülésemből kifolyólag nem tudok egyidejüleg szájról olvasni és írni), harmadik személy nem lehetett volna jelen az interjún (így a szájól olvasási tolmács nem tudott volna elkísérni), az elhangzottak nem kerülhettek volna kívülálló személy kezébe (vagyis a legépelés sem valósulhatott volna meg), a kérdéseket el kellett volna küldenem jóváhagyásra az adatvédelmi felelősüknek. Egyrészt nem szerettem volna kifutni az időből az újabb hosszas egyeztetési folyamat miatt, másrészt attól tartottam, ha elözetesen felkészítik az interjúalanyt, nem kapok reális képet a témakörröl, valamint az eredményeket sem publikálhattam volna. Ezért úgy döntöttem, hogy más megoldást keresek.

3. Egy-egy interjúalanyon éreztem a feszültséget a beszélgetés elején. Minden interjú elkezdése előtt megkértem a beszélgetőtársaimat, hogy a hallássérülésem és „segítőkutyás mivoltom” ne befolyásolja őket, hiszen nagyon fontos számomra a véleményük. Ez hatott, mindenki gyorsan feloldódott. Szempont volt számomra az is, hogy ne terheljem túl őket olyan témakörök tárgyalásával, amelyekben esetleg nem mozognak otthonosan.

4. A 15 beszélgetésből 8 alkalomra mentem el a segítőkutyámmal. Például érdekes vizsgálati tapasztalat volt, amikor az intézményvezetöre várakozva egy biztonsági őr megkérdezte, hogy miért nincs szájkosár a kutyámon (a 2009-es rendelet külön kiemeli, hogy nem kötelező, mert akadályozná a segítőkutya munkáját). Minden interjúalany pozitívan fogadta a kutyámat, bár az iránta tanúsított érdeklődés eltérő mértékű volt. Volt, aki „csak” kérdést tett fel, volt, aki szó nélkül megsimogatta, de olyan is, aki engedélyt kért rá. Más esetben pedig vizet hoztak neki, vagy az adott intézmény minden munkatársa „körülrajongta".

Tisztában vagyok azzal, hogy a felmerült problémák torzító hatással lehetnek a kutatási eredményekre, azonban a kutatás egészét nem befolyásolták, hiszen így is sikerült releváns információkat kapnom, és összességében elmondhatom, hogy mindegyik interjú sikerrel zárult. Úgy éreztem, hogy gyorsan bizalmukba fogadtak a beszélgetőtársaim, például néhányszor az is elhangzott, hogy „kérem, ez ne kerüljön bele az anyagba, mert az állásomba kerülhet”. Ezeket a részleteket természetesen kivettem az interjúszövegekböl.

Többen kérték az interjú után, hogy küldjek összefoglalót a jogszabályi háttérről, így készítettem számukra egy tájékoztatót. Ezen túl a beszélgetőtársaim jelentős 
része érdeklődve kérdezett a segítőkutyák világáról (például alkalmas kölyökkutyák kiválasztásának folyamata, segítségnyújtás formái, képzés hossza).

Úgy tapasztaltam, hogy az én fogyatékosságom, a segítőkutyám jelenléte és az ajándékba adott gyermekkönyv attitüdformáló hatással is volt. Ezt egy levélrészlettel szeretném alátámasztani, amit egy olyan intézmény vezetőjétől kaptam, ahol az egyik gazda beszámolója alapján korábban problémába ütközött a szolgáltatás igénybevétele segítőkutyával:

„Szeretnék egy kis visszajelzést adni a személyes beszélgetésünk után. A kollégámmal meg is beszéltük a találkozásunk után, hogy a segítőkutyákat egy személyként vesszük a gazdájával és nem külön kutyaként, hogyha a jövőben megfordul valaki nálunk. A mesekönyv pedig nagyon tetszik a kislányomnak, és nekem is. Köszönöm, hogy én is betekintést nyerhettem ebbe a világba!"

Olyan is előfordult, hogy az interjúalanyom gyors, rögtönzött „értekezletet” hívott öszsze, amíg ott voltam.

„Nem tudom (a választ), de mindjárt megkérdezem, jó? Én is kíváncsi vagyok.”

Miután visszajött, így szólt:

„Érdekes, mert volt egy beszélgetésünk erröl, mert ugye nem volt még ilyen példa, de arra gondoltunk, hogy (...) ha ez egy segítőkutya, akkor nyilván nem kell fizetni (extra díjat a szállás igénybevételekor), mert ez az életed része."

Az egyik orvos, aki biztos volt abban, hogy a törvény kizárja a segitőkutya rendelöbe való belépését, plusz információt kaphatott a beszélgetés alatt.

„Ha ez a kislány be akar menni a kórházba, akkor sajnos tényleg nem viheti magával a kutyát. (...) Nem lesz soha jogszabályilag megengedve. (...) Szerintem a gazdát is tájékoztatni kell, hogy a kutyahasználatnak is vannak korlátjai."

Nagyon meglepődött, miután megmutattam neki, hogy még a kórház házirendjében is szerepel, hogy élőállatot nem lehet behozni, a segítőkutyák kivételével.

„Hát ezen most el kell gondolkodnom. (...) Elképesztő sok tájékoztatás van kitéve a rendelő falára, hogy miért pont ez nincs kirakva?!"

Egy másik interjúszemély, aki - a mindennapi munkája mellett - járművezetőket is oktat, elmondta, hogy a segítőkutyák jogairól szóló összefoglalómat be fogja építeni a tananyagba.

„Azért is vállaltam el (az interjút), mert ez nekem is egy nagy tanulság. (...) Nagyon sokat lehet a másik embertöl tanulni úgy, hogy észre sem veszem, hogy én most tanultam tőled. (...) Én is másképp fogok ezentúl az egészre tekinteni. (...) Ez a segítőkutyás dolog olyan, hogy akkor most ennek is egy kicsit jobban utánanézek." 


\section{INTERJÚANYAGOK FELDOLGOZÁSA}

A (köz)szolgáltatási intézmények képviselőivel készített interjúk legépelt változata összesen 189 oldalt tett ki. Az elemzést MAXQDA szövegelemző programmal végeztem (Juhász, 2009; Sántha, 2013, 2017). Azért választottam ezt a megoldást, mert a „másik oldal” szempontjait kevésbé ismerem, mint a segítőkutyák területét, de a szoftvernek köszönhetően átláthatóbbá vált az adathalmaz, könnyebben tudtam tematizálni a kapott információkat.

A föbb elemzési szempontok a következők voltak: 1) fogyatékossággal élő emberekkel kapcsolatos ismeretek, 2) információk a segítőkutyákról és munkájukról, 3) tájékozottság a jogszabályi háttérről, 4) segítőkutyák alkalmazásának hatása, 5) ötletek a konfliktushelyzetek megoldása érdekében.

A Word-dokumentumban található szövegkorpuszok előkészítése után előzetes kódlistát gyártottam - a saját tapasztalataim és a rendelkezésre álló információk (szakirodalmi források, segítőkutya-gazdákkal végzett kérdőíves és interjús vizsgálat eredményei) alapján. Végül 6 fökód született, melyek követték az interjúkérdések és az elemzési szempontok tartalmi egységeit. Ezekhez alkódokat rendeltem, majd újabb, még mélyebb kategóriákat definiáltam, vagyis többszintű rendszerezés valósult meg.

Az alábbiakban bemutatok egy egyszerủ példát a többszintű kódolásra:

1. Ismeretek a fogyatékosságról

1.1. Fogyatékosság/nehézség típusai

1.1.1. Látássérülés

1.1.2. Mozgássérülés (...)

1.2. Személyes kapcsolat

1.2.1. Családtag

1.2.2. Ismerős, barát (...)

Összesen 66 kóddal 1148 egységet (például szó, mondat, bekezdés) kódoltam. A következő ábrán látható kódtérkép szemlélteti a többszintü kódkategória-gráf strukturális kapcsolatait (az alkódokat más-más színárnyalattal jelöltem).

Annak ellenére, hogy a MAXQDA szoftver nagyban hozzájárult az összefüggések mélyebb, objektívebb feltárásához, történt kvalitatív elemzés is. Az interjúalanyok válaszait szó szerint idézem, például abban az esetben is, ha a fogyatékossággal kapcsolatban esetleg nem a Fogyatékossággal élő személyek jogairól szóló egyezmény és az ahhoz kapcsolódó Fakultatív Jegyzőkönyv kihirdetését tartalmazó 2007. évi XCII. törvény (továbbiakban: fogyatékosságügyi ENSZ egyezmény) és a „People First” mozgalom szellemiségét tükröző kifejezések szerepelnek bennük (Horváth, 2007). 


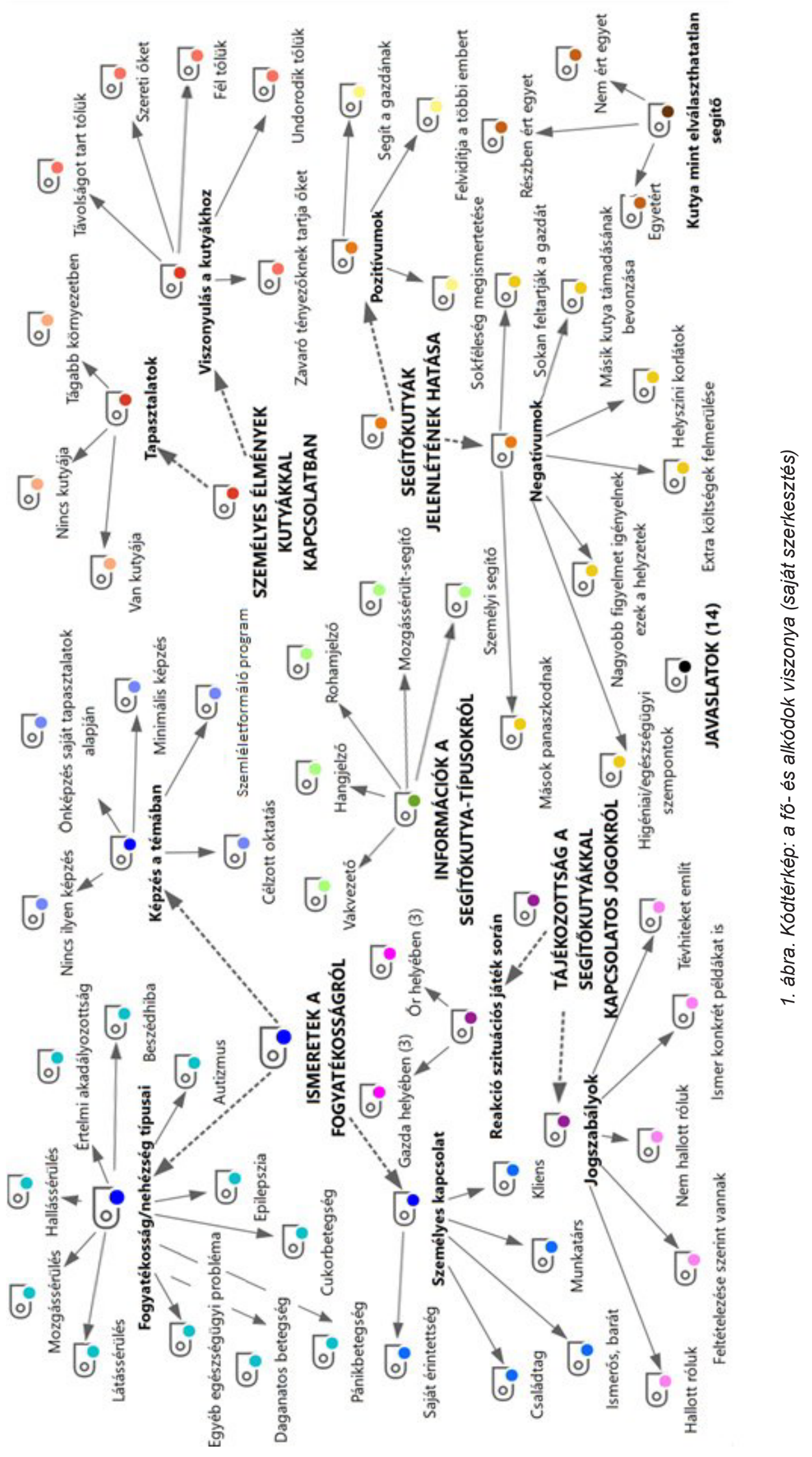




\section{AZ INTERJÚBESZÉLGETÉSEK KIEMELT TANULSÁGAI}

Beszélgetőtársaim gyakran álltak pozitívan a témához, és kiemelték a segítőkutyák alkalmazásának előnyeit. Valamint az is érdekes volt, hogyan változott az egyes interjúalanyok szemlélete az együtt töltött idő alatt. Például a beszélgetéseket mindig a következő felvetéssel zártam: „Egyszer egy gazda azt nyilatkozta, hogy ha arra kéri egy intézmény üzemeltetője, hogy hagyja kint a segítőkutyáját, úgy érzi, mintha azt várná egy mozgássérült személytöl, hogy csatolja le a lábprotézisét, mielőtt belép a közszolgáltatást nyújtó területre. Egyetért ezzel a párhuzammal?" Ezzel az állítással mindegyik interjúalany egyetértett a beszélgetés végére.

Azonban - a tanulmány céljának megfelelően - az eredmények bemutatásakor elsősorban azokra témakörökre fókuszálok, amelyek még megoldást igényelnek az interjúbeszélgetések tapasztalatai alapján.

\section{A segítőkutyákkal és a jogszabályi háttérrel kapcsolatos információk ismerete}

A beszélgetések során többször elhangzottak olyan tévhitek az interjúalanyok részéről, amelyek megfelelő tájékoztatással valószínűleg kiküszöbölhetők lennének. A gyakrabban előforduló, tipikus félreértéseket az alábbi táblázatban összesítettem.

A legelterjedtebb vakvezető kutyákon kívül jellemzően nem gondoltak arra beszélgetőtársaim, hogy másfajta nehézséggel élő emberek is alkalmazhatnak segítőkutyát. Csak a légitársaság munkatársa tudott minden segítőkutya-típust felsorolni, de azt is hozzátette, hogy ő olvasta a családjával a Kuku és barátai - Ismerjük meg közösen a segítőkutyák világát! című mesekönyvet, illetve van négylábú segítőtárssal közlekedő ismerőse, ezért otthon érzi magát a témában. A 2. sz. kórház sebészén kívül mindenki utalt a vakvezető kutyákra (14 fö), utána a mozgássérült-segítő kutyák (6 fö), majd a hangjelző kutyák (4 fö) következtek. Megjegyzem, hogy a hallássérült-segítő kutyák létezését az én jelenlétemböl is kikövetkeztethették. Az interjúalanyok elenyésző arányban hozták szóba a rohamjelző (3 fő) és a személyi (2 fő) segítőkutyákat. A beszélgetőpartnereim közül heten egyáltalán nem hallottak a szóban forgó jogszabályokról, négyen csupán feltételezték a létezésüket. Mindössze öten válaszolták azt, hogy van tudomásuk ezekről, illetve ennyien említettek konkrét példákat, azonban a részletekkel kapcsolatban hét interjúalany tévhitet osztott meg. 
1. A vakvezető kutya az egyetlen segítőkutya-típus Magyarországon.

2. Nincs olyan jogszabály, amely lehetővé teszi, hogy a segítőkutyák bekísérjék a gazdájukat (köz) szolgáltatást nyújtó intézményekbe.

3. A segítőkutya elzárása jó megoldás lehet.

4. A segítőkutya is lehet neveletlen és balesetveszélyes.

5. A segítőkutya könnyen lecserélhető emberi segítségre.

6. A gazda megkérhető/kötelezhető arra, hogy tegyen szájkosarat a segítőkutyájára.
„Vakvezető kutyákon kívül van még más segítőkutya-típus? Megvan, rendőrségi és mentökutyákról is hallottam." (2. sz. hotel menedzsere) megengedve. (...) Sajnos tényleg nem viheti magával a kutyát. (...) Biztos vagyok benne, hogy lesz itt elakadás a bejutásnál." (1. sz. kórház orvosa)

„A szálláshely az olyan dolog, hogy (...) ha a szobába nem is lehet felvinni, akkor legyen az udvaron kennel, ahova elhelyezik." (2. sz. állatkert igazgatója)

Ezek a nehéz helyzetek, ilyenkor kell nekünk rövid idő alatt meghozni döntéseket. Ami lehet, hogy jó lesz, de (...) nem biztos, hogy jó fog történni, mert az a kutya megharap valakit. Akkor utána ki lesz a felelős?" (járművezető)

„A kutyákat azért nem szeretjük mi, mert ugatnak, a vendégeket felzavarják. (...), összetörik az asztalt." (2. sz. hotel menedzsere)

„Számomra valamiért az él erről, hogy valahol kicsit kiszámíthatatlan a kutya. (...) Bizonyos helyekre kell szorítkozni, vagy valami vizsgához kötni. (...) Mi a biztosíték arra, hogy a segítőkutyák nem harapnak?" (2. sz. kórház orvosa)

„Ezzel kapcsolatban azt gondolom, hogy aki kutyával jön, az egyedül jön. Ha nem egyedül jönne, akkor lennének vele emberek, akkor nem kellene neki segítőkutya." (2. sz. hotel menedzsere)

"A segítőkutyánál egy segítő ember mégiscsak jobb." (2. sz. állatkert igazgatója)

„Mindenképpen megkérném, hogy vegye fel (a kutya) a szájkosarat. Lehet, hogy csak véletlenül elfelejtette (a gazda)." (járművezető)
Ma már nem csak látás-, hanem mozgás-, hallássérült vagy autizmusban érintett emberektől az epilepsziás vagy klausztrofóbiás, pánikbeteg gazdákon át diabéteszes vagy gluténérzékeny személyeknek is képeznek segítőkutyákat.

Az 1998-as esélyegyenlőségi törvény és a 2009-es rendelet szabályozza a segítőkutya-gazdák jogait.

A jogszabályok lehetővé teszik, hogy segítőkutyák bemehessenek a gazdájukkal - többek között szálláshelyekre, még a szobákba is. A gazdák nem kötelezhetők arra, hogy kennelben hagyják a segítőtársukat, hiszen a nap 24 órájában szükségük lehet rájuk (például a tũzriasztó vagy az alacsony vércukorszint jelzése életmentő lehet).

A segítőkutyák nem hasonlíthatók össze „sima” házi kedvencekkel, a 2009-es rendelet alaposan szabályozza a segítőkutyák képzésének és vizsgáztatásának menetét. A vizsgázott segítőkutyáknak szigorú egészségügyi és képzettségi követelményeknek kell megfelelniük, melyeket központilag delegált vizsgabiztosok ellenőriznek, államilag elfogadott szabályzat alapján. Ezenkívül a rendelet kiemeli azt is, hogy a gazdának mindent el kell követnie annak érdekében, hogy a segítőkutya ne zavarjon másokat.

Ahogy segítőkutya-gazdákkal készített kérdőíves felmérésböl és interjúkból is kiderült, sokszor a kutya által nyújtott segítséget részesítik elönyben. Ráadásul gyakran a segítőkutya olyan dolgokra (például epilepsziaroham elörejelzésére) is képes, amire az ember nem.

A 2009-es rendelet hangsúlyozza, hogy a segítőkutyáknak nem kell szájkosarat viselniük, hiszen az akadályozná a munkájukban. 


\section{A konfliktushelyzetek hátterében húzódó lehetséges okok - a szolgáltatást nyújtó intézmények szemszögéböl}

A pozitívumok mellett rákérdeztem arra is, hogy a beszélgetőtársaim milyen hátrányt tulajdonítanak annak, ha egy fogyatékossággal élő ember segítőkutyával megy be egy közszolgáltatást nyújtó helyszín mindenki számára nyitva álló területére. Négy interjúalany kivételével mindannyian elmondták, hogy attól tartanak, hogy mások panaszkodni fognak a segítőkutya jelenléte miatt, összességében erre a problémára tértek vissza a leggyakrabban (összesen harmincötször). Ezután a higiéniai szempontokra utaltak a legtöbbször (harmincszor). Bár jóval kevesebbszer, de megjelent az a gondolat, hogy nagyobb figyelmet igényelnek ezek a helyzetek (tizenhatszor). Felmerült az is, hogy extra költségvonzata lehet a segítőkutyák ott tartózkodásának (összesen nyolcszor). A helyszín szűkösségét (például repülö) kétszer említették, egyszer szóba jött az is, hogy a segítőkutyáknak köszönhetően kívülállók feltarthatják a gazdájukat, illetve más állat támadóan léphet fel velük szemben (kétszer). Az indoklások közül az alábbiakban ismertetek néhány jellegzetes példát.

Tanulságos volt meghallgatni a légitársaság nyilatkozójának tapasztalatait, miszerint a vállalat kifejezetten a saját leírt szabályai szerint működik, a fogyatékossággal élő személyekhez és a segítőkutyákhoz is így áll hozzá.

„Csak a szükségeset engedi meg. (...) Az idő rendkívül értékes a légitársaság számára. (...) Nekünk mindig professzionálisan kell viselkednünk. (...) Egy picit a repülés kezdi elveszíteni az emberi arcát ebből a szempontból."

Az interjúalanyok közül többen problémának látták, hogy a szolgáltatók alkalmazottainak jelentős része nem vett részt olyan képzésen, ahol a fogyatékossággal és segítőkutyákkal kapcsolatos információkról hallhatott volna. Köztük a mentőtiszt tért vissza erre a kérdésre a leggyakrabban.

„Sajnos az egész egészségügyre (...) nem jellemző az erre való felkészítés. (...) Tehát így nagyon nehéz, (...) az iskolarendszerben nem tanítják, a továbbképzéseknek nem szokott témája lenni. Nincs, aki megtanítsa nekik."

Ezt a két orvos is megerősítette. Például:

„Megtanítják, hogy a látással mi romlik el (...), annak a lelki hátteréről és ez milyen hatással van ez a beteg életére, nem esik szó. Az egyetemről úgy jövünk ki, hogy irgalmatlan mennyiségü elméleti tudással rendelkezünk, és semmilyen gyakorlati képzésen nem esünk át."

Meglepő módon, hasonlóan vélekedett a rendőrségen és a tűzoltóságon dolgozó interjúalany is, pedig talán ezeken a területeken lenne a legfontosabb az ilyen irányú oktatás.

A megfelelő emberi hozzáállás fontosságát is többen megemlítették.

„Magyarország szerintem az előítéletek országa. Minden tiszteletem az Önöké, hogy igenis élnek és csinálják, ez fantasztikus. Miközben tudom, hogy mennyien elfordulnak tölük, és tele vannak elöítélettel. (...) Sajnos sok vendégnek nem tetszik [a programok szervezése fogyatékos látogatóknak], ennek hangot is adnak. (...) Ezt a döntést nem volt nehéz meghoznom, mert 
én nagyon mélyen egyetértek [az inkluzív programokkal]. (...) Én meg egy boldog igazgató szeretnék lenni, és már csak ezért is csinálom." (1. sz. fürdő igazgatója)

A 2. számú kórház képviselője őszintén elmondta, hogy ő fél a kutyáktól. Az okát is elárulta az orvos: sebészként sokszor olyan sérülést kell ellátnia, ami kutyaharapás miatt keletkezett.

„Én bizalmatlan vagyok. (...) De azt tudniuk kell, hogy én sokszor a kutya által okozott sérülésekkel foglalkozom. Én magam is ennyi sérülés láttán kicsit tartózkodóbb vagyok."

A 2. számú hotel menedzsere pedig kifejezetten negatív érzelmeket osztott meg a kutyákkal kapcsolatban: retteg és „undorodik” tőlük, zavaró tényezőnek tartja őket. Tehát egy személy hozzáálása is befolyásolhatja a szolgáltatások segítőkutyával történő igénybevételét (például az a szálláshely, amelynek a vezetője így viszonyul a kutyákhoz, valószínủleg fenntartásokkal vagy egyáltalán nem enged be segítőkutyákat).

Beszélgetőtársaim felhívták a figyelmemet arra az aggodalmukra is, hogy nem csak a (köz)szolgáltatást nyújtó intézmény üzemeltetőjén és dolgozóin, hanem a többi jelenlévő emberen is sok minden múlik:

„Azért tudjuk azt, hogy mindenféle vásárló megfordul nálunk, föleg egy hipermarketben. Mi azért nagyon széles vásárlói közönségnek kínálunk termékeket, mindenféle ember megfordul.” (1. sz. áruház vezetője)

„Patthelyzet. Egyébként nem megoldhatatlan, csak az a szerencsétlen ör a kórházat képviseli. Olyan dologban kellene döntést hozni, amiben nincsen felhatalmazva vagy elég jól kiképezve. Ha viszont ki is van képezve, és azt mondják, Pista bácsi, ha segítőkutya jön, ott van rajta a jel, engedd be, itt van a jogszabály. Beengedi, és 15 percen belül 30 ember fog kiabálni. (...) Olyan problémahalmaz fog elindulni, hogy a figyelem elindul egy rossz irányba. Nem a [gazda] betegségével fognak foglalkozni, hanem mi lesz a kutyával, a többiek mit szólnak." (1. sz. kórház orvosa)

„A repülőn nagy a zsúfoltság. Ha esetleg van valaki, aki fél a kutyától vagy allergiás rá, azt valamilyen módon respektálni kell. Ezért van az, hogy járatonként csak egy kutyát fogad el a cég. (...) Olcsóbbak lettek a jegyek, megnyílt egy olyan utazóközönség számára is az utazás lehetősége, akiknek igazán nem nagyon lenne helyük repülögépen. (...) A legalapvetöbb viselkedési normákat sem tartják be. (...) Vannak olyan bulidesztinácók, a fociszurkolók, akik jönnek legénybúcsúzni Budapestre törpnek öltözve, meg mindenfajta utassal találkozunk gyakorlatilag." (pilóta)

„Valakinek az érdekei sérülni fognak. (...) Ebben az esetben megkérném őket, hogy tisztes távolságra álljanak egymástól (a segítőkutya-gazda és a reklamáló utas). Ha meg nem tudnak megegyezni, akkor megkérem őket, hogy szálljanak le, és jöjjenek a másik busszal. Ez nagyon nehéz, mert, ha az egyiket elviszem, akkor úgyis a másik fog megsértődni." (jármüvezető) 
„A hátránya az a többi vendég reakciója: mit szólnak ahhoz, ha letelepednek mellé egy zárt térben egy segítőkutyával? Nem tartom elkerülhetőnek a konfliktust, sokan meg fogják jegyezni. (...) Bele kell állni, és el kell magyarázni, hogy erre jogszabály van. Ő azt fogja mondani, hogy nekem ne beszéljen, egy ilyen színvonalú hely nem engedheti meg magának, és soha többet nem fog idejönni." (1. sz. fürdő igazgatója)

Rávilágított arra is a fürdöben dolgozó beszélgetőtársam, hogy nagy extra költség terhelheti az intézmény üzemeltetőjét.

„Nyilván a kutyus higiéniai jellemzői (...) is kérdés bennem, az emberek átöl-
töznek, papucsba lépnek. (...) Nekem véleményes, hogy egy kutya, aki bejön
az utcáról, ugyanúgy végigmegy a fürdő terén, hogy az mennyire higiénikus,
avagy nem. (...) A medence vizének összetételére nagyon komoly elöírások
vannak, ha egy állat belép (a fürdő területére), és ha mintát vesznek, akkor
azonnal büntetnek. (...) Csak azért lovagolok ezen ennyit, mert jó pár ellen-
örzésen vagyok túl, és tényleg oda kell figyelni mindenre. (...) Ha ezt meg-
látja egy ÁNTSZ-ellenőr (...), nekem le kell engedni a medencét, 16 óra alatt
engedem le, 16 óra alatt töltöm fel, és újabb 12 óra, mire eléri a szükséges
hőfokot. Ha ez a medence nincs, akkor az egész ház megáll, mert ezért jön-
nek a vendégek. Tehát ez nem 1 millió Ft-os kár, hanem jóval afeletti.” (1. sz.
fürdő igazgatója)

A 2. sz. állatkert igazgatója megerősítette az ott járó segítőkutya-gazda véleményét, hogy a rendelkezésre álló kennel nem volt alkalmas arra, hogy kutyát tegyenek be oda (lásd 1. táblázat), sőt azóta korszerübb és biztonságosabb helyszínt alakítottak ki erre a célra (ami már kulcsra zárható és árnyékos). Azt viszont hangsúlyozta, hogy - bár az állatkert szabadon mászkáló lakói miatt balesetveszélyesnek tartja segítökutya bevitelét - ők nem kötelezik a gazdákat, hogy váljanak meg a segítőkutyájuktól.

„Ezért csináltunk (...) szép és jó minőségű tartó helyet a kutyáknak. És ha van rá igény, akkor a kutyákat lecseréljük emberre. Nagyon szívesen adunk hostesseket, zoopedagógusokat a kutya helyett a vendégnek, aki végigkíséri, és mi vigyázunk a kutyájára. (...). Elmondjuk, hogy van ez a házirend, értse meg, nézze meg, hogy hol tartjuk a kutyát. (...) Ha az illető annyira ragaszkodik a kutyához, akkor bemehet."

Utaltak arra is az interjúalanyok, hogy alapvető probléma, hogy a biztonsági szolgálatot végző személyeket külső cég biztosítja, és nincs lehetőség alapos felkészítésükre.

„Nem akarok senkit megbántani, nagyon alacsony a színvonal. Annyi pénzért azt csinálni, hogy mondjam. Amikor 12 órát ott vannak egész nap, alacsony az iskolai képzettségük, nincsenek erre kiképezve." (járművezető)

„Ezt a jogszabályt tudják a dolgozók, a biztonsági őr, az egy kicsit más. Itt vannak ugyan, de nem a mi alkalmazottjaink. Van, amikor mi sem mondunk el nekik mindent, mert sokszor más jön, van, hogy minden nap más jön. Minden nap azzal kezdeni, nekünk sincs időnk rá." (2. sz. áruház képviselője)

A munkatársak kapacitáshiányára a pilóta is utalt:

„Amennyire én látom, ha megkeressük őket bármilyen ilyen jellegű oktatási javaslattal, nem sikerülne. (...) Mindenki el van foglalva gyakorlatilag a sa- 
ját problémájával. Bármilyen extra dolgot ebbe belevinni, én azt látom, hogy nem lehet. A jogszabályi kötelezettségekbe foglalt képzésekkel is mindig küzdünk, hogy az mindig meglegyen határidöre. (...) Elöször úgyis az lenne a válasz, hogy ó, persze foglalkozunk vele, de utána ez elsikkadna." (légitársaság képviselője)

Többen kiemelték, hogy bizonyos esetekben hiába engedné be szíve szerint a segítőkutyát egy munkavállaló, félhet annak a következményeitöl.

„Gondoljuk bele magunkat (...) annak a recepciósnak a helyébe, aki pozitív lenne (...), ha tudja, hogy ö terrorban van tartva a tulajdonos által. Ha a fönök azt mondja, hogy ha meglátok itt egy fogyatékost, akkor úgy kivágom, meg magát is, akkor már görcsben van a gyomra, ha meglát (...) egy látássérültet egy kutyával." (1. sz. fürdő igazgatója)

Annak a légitársaságnak munkatársával beszélgettem, ahol az az incidens történt, hogy egy gazdát a segítőkutyájával együtt kiszállítottak külföldre, de a hazautazás már komoly nehézségekbe ütközött (lásd 1. táblázat). A pilóta szavai kicsit bepillantást nyújtanak a háttérben húzódó okokba:

„Mi a légitársaságnál az utasokat szállítjuk repülőgéppel. Minden, ami ezen kívül történik, például az utasok odajuttatása a repülőgéphez, vagy akár csak a mozgássérült utasok szállítása a reptéren belül, ez mind külön cég. (...) Mindegyik cégnek megvan a kézikönyve, amit tudniuk kéne és alkalmazni kéne. (...) Korábban a mi utazási feltételeinkben az szerepelt, hogy csak vakvezető kutya utazhat, egyéb segítőkutya nem. (...) Ez is még az utazás előtt volt bőven, erre rájöttek, korrigálták ezt a hibát, utána szétküldték ezeknek a cégeknek minden repülőtérre. (...) De valamilyen oknál fogva nekik még nem volt meg az új dokumentum. (...) Emiatt volt az, hogy őket nem engedték akkor beszállni." (pilóta)

Úgy látszik, hogy a szabályozások összeegyeztetésének hiánya más területen is bonyodalmakat okoz. Ugyanis ezt a kérdést például mindkét fürdő képviselője is említette:

„Sokszor az a baj a törvényhozással, hogy íróasztal mögött hoznak egy szabályt, de lehet, hogy még életében nem volt fürdöben. (...) Az egyik hatóság, jogalkotó ellentmond a másiknak. Mert a másik olyan (...) törvényt hoz, amibe egészen egyszerüen nem fér bele, hogy egy kutya ott sétáljon a fürdőtérben. Akkor melyiket tartsam be?" (1. sz. fürdő igazgatója)

„Jogásszal meg kellene beszélni, hogy kiírhatjuk-e azt, hogy háziállat behozatala tilos, kivéve segítő jellegü kutyák. (...) Ha konkrétan jogszabályban szerepel, ez számomra borzasztó jó hír, mert innentől kezdve szabad a pálya. (...) Megmondom őszintén, amikor volt ez az ominózus eset a nyáron, akkor megpróbáltam utánanézni, de nem találtam konkrétumot." (2. sz. fürdő vezetője)

Több segítőkutya-gazda vetette fel azt a problémát, hogy ha rosszul lesznek például az utcán, a mentősök nem kötelesek elvinni a segítőtársukat. Az érintett szakember ezzel a magyarázattal szolgált: 
„Mondhatnám azt, hogy be kell tenni a segítőkutyát, de nem jó, mert a mentőben kicsi a hely. Még hozzátartozót sem mindig viszünk el, pont azért, mert hátráltatja a mi ellátásunkat, akár az egyszerủ megnyilvánulásaival. (...) Szakmai protokolloknak teszünk eleget, ott nincsenek szubjektív elemek legtöbbször. (...) Nehéz elképzelnem, hogy a segítőkutyát hogyan rögzítjük, a mentöben alapfeltétel, hogy csak rögzített emberek lehetnek. Ugye nagyon gyorsan mennek, fékeznek, a kutya is a tehetetlenség miatt lehet okozója egy balesetnek (...), a kutya valakinek okozhat sérülést. Akaratán kívül nyilván. (...) Ez egy fontos dolog, a kutya élete is veszélyben van, és ő is veszélyeztethet. (...) Jön a sziréna, tülkölés, olyan dolgok, amikhez biztosan nem szokott hozzá, a hirtelen fékezés." (mentőszolgálat képviselője)

A másik két mentésben illetékes interjúalanyomtól (rendőr, tüzoltó) megkérdeztem, hogy mit tudnak tenni, ha egy gazda nem tud az adott helyzetben gondoskodni a segítőkutyájáról. Ezt azért tartottam fontosnak tisztázni, mert ebben a célcsoportban még nagyobb a kockázat (például ha egy epilepsziás gazda elveszti az eszméletét közterületen). A nyilatkozatok azt sugallják, hogy a különböző szervek nem rendelkeznek olyan protokollal, amely útmutatást ad, hogy hogyan tudnák kezelni a váratlan szituációkat, amikor a segítőkutya magára marad. Úgy látszik, hogy a megoldás és az összehangolt munka az éppen kiérkező szakemberek egyéni rugalmasságán, kreativitásán múlik.

\section{KONKLÚZIÓ:}

\section{A KUTATÁSI TAPASZTALATOK ÖSSZEGZÉSE}

A (köz)szolgáltatást végző helyszínek képviselöivel készített interjúk alapján három fő kategória rajzolódik ki a segítőkutyákhoz való viszonyulást tekintve.

1. Beengedik a segítőkutyákat, a motiváció elsősorban a jogszabályi kötelezettségek teljesítése (vagyis nem feltétlenül érzik magukénak az esélyegyenlőség ügyét). Erre jó példa volt a légitársaság:

„A légitársaságról azt tudni kell, hogy nem egy jótékonysági szervezet. A légitársaság azért van, hogy pénzt termeljen a befektetőknek. Ez az igazság. (...) A légitársaság, ha próbálnánk megszemélyesíteni, akkor elfogadja ezt a dolgot, mert a jogszabályok kötelezik rá, de az, hogy úgymond a légitársaság vezetőségének bármilyen pozitív érzelme lenne ezzel kapcsolatban, azt nem hiszem." (pilóta)

2. A másik „véglet”, amikor az üzemeltető/dolgozó emberi hozzáállása miatt gördülékeny a szolgáltatás igénybevétele segítökutyával, akkor is, ha esetleg az intézményben nem ismert a szóban forgó jogi háttér. Például az egyik interjúalanyom el se tudta képzelni, hogy elő szokott fordulni, hogy egy mindenki előtt nyitva álló területre nem vagy nehezen jut be egy segítőkutya-gazda.

„Ez olyan hihetetlen, olyan alapdolog. Ez olyan, mintha azt mondanák, hogy vedd le a szemüveget, amikor bejössz. (...) Ez olyan, mintha nem mehetnél be egy kerekesszékkel vagy egy járókerettel. Vagy egy szemüveggel, ez egyszerüen szükséges." (1. sz. szálloda menedzsere) 
3. Az eredmények alapján úgy tűnik, hogy probléma leginkább olyan intézményeknél szokott felmerülni, ahol bizonytalan, tisztázatlan körülmények állnak fenn, és emiatt nem látják az érintett dolgozók, hogyan lehetne a helyzetet hatékonyan kezelni. Néhány példa, hogy a (köz)szolgáltatást képviselő alkalmazottakban - a személyes véleményüktöl függetlenül - mi okozhat kételyt:

3.1. információhiány a segítőkutyák és/vagy az őket érintő jogszabályi háttér létezéséről;

3.2. ellentmondások különböző rendelkezések között (például Nemzeti Népegészségügyi Központ ellenörzései);

3.3. kutyákkal kapcsolatos általános rossz tapasztalatok, tévhitek (például a segítőkutyák is haraphatnak);

3.4. konfliktusoktól való félelem (például főnök, más jelenlévők reklamációi).

Ideális helyzetben a szolgáltatók ismerik és biztosítják a segítőkutya-gazdákat megillető jogokat, ugyanakkor a hozzáállásuk is megfelelö. Azonban folyamatosan változhat, hogy egy-egy helyszín melyik kategóriába kerülhet, hiszen ez sok tényezőtől függ. Ilyen az éppen szolgálatban lévő biztonsági őr viszonyulása a fogyatékossággal élő emberekhez vagy az állatokhoz.

Tisztában vagyok azzal, hogy ezek a következtetések kis létszámú mintán alapulnak, így az eredmények nem általánosíthatók. Ezért is szándékozom kidolgozni a szolgáltatók felmérését segítő kérdőívet, mely már tartalmazná a jelen kutatás tapasztalatait.

\section{JAVASLATOK MEGFOGALMAZÁSA}

Az interjúalanyok számos kreatív ötletet adtak, hogy megítélésük szerint mit tehetnénk a segítőkutyák társadalmi elfogadottságának növelése érdekében, melyeket belefüztem a tanulmányt záró ,javaslatcsomagba”. A segítőkutya-gazdák társadalmi beilleszkedésének eredményességét befolyásoló tényezők két oldalról közelíthetők meg, hiszen ehhez nem csak a megfelelő környezeti elemek, hanem az egyén integrációs törekvései is szükségesek.

A segítőkutya-gazdákkal és közszolgáltatást nyújtó intézmények képviselőivel végzett kutatás eredményeire alapozva állítottam össze az alábbi cselekvési tervet, mely megvalósításán folyamatosan dolgozunk a NEO Magyar Segítőkutya Közhasznú Egyesületnél.

\section{Szemléletformálás, a társadalom tájékoztatása a segítőkutyák létjogosultságával kapcsolatban}

1.1. médiamegjelenések, videókampányok, Facebook-hirdetések, blogok;

1.2. szórólapok, tájékoztató füzetek;

1.3. matrica készítése a szolgáltatási intézményeknek, amit ki tudnak tenni a bejáratra (például „állat nem hozható be, kivéve segítőkutyák”);

1.4. tájékoztató kártyák, amelyeket a gazdák be tudnak mutatni, ha valaki kérdőre vonja őket;

1.5. „celebek” megnyerése az ügy képviseletére;

1.6. a társadalomban elterjedt esetleges tévhitek eloszlatása (például „a segítőkutyák is lehetnek neveletlenek és haraphatnak"). 


\section{Kezdeményezés különböző kiképző szervezetek munkájának összefogására}

2.1. egységes protokollok kidolgozása;

2.2. feltűnő, egyféle hám, megkülönböztető jelzés készítése (a többféle jelzés miatt sokszor nem tudják kívülállók beazonosítani, hogy valóban segítőkutyáról van-e szó);

2.3. közös információs csatornák, egységes kommunikáció kialakítása.

\section{Kapcsolatfelvétel külföldi szervezetekkel}

3.1. jó gyakorlatok megosztása egymással;

3.2. protokollok, helyi szabályzatok egységesítése (például a légitársaságok azonos, előre kiszámítható policy szerint kezeljék az egyes eseteket);

3.3. a felmerült problémák okainak tisztázása/megoldása.

4. Együttmüködés szakmai és oktató szervezetekkel (például Magyar Szállodák és Éttermek Szövetsége, Nemzeti Népegészségügyi Központ, biztonsági őröket képző intézmények)

4.1. illetékes szervezetek összefoglaló tájékoztatása a különböző segítőkutya-típusokról és az őket érintő jogszabályi háttérről;

4.2. közreműködés képzési programok kidolgozásában, valamint képzések és szemléletformáló tréningek tartásában (például biztonsági őrök, segítő szakmában dolgozó szakemberek felkészítése);

4.3. a szervezetek segítségének kérése, hogy minél több (köz)szolgáltatási intézményhez eljuthassanak az információk;

4.4. megoldások közös keresése a problémákra (például mi legyen a segítőkutyával, ha a gazdája rosszul lesz az utcán, és elviszi a mentő).

\section{Pályázati rendszer stabilizálása}

5.1. szemléletformálás annak érdekében, hogy a vakvezető kutyákon kívül más segítőkutya-típusok képzése is nagyobb teret, pénzügyi támogatást kaphasson.

\section{Segítőkutyákat érintő dokumentációk folyamatos felülvizsgálata}

6.1. szolgáltatási intézmények házirendjének kiegészítése („tilos állatot bevinni, kivéve segítökutyák"), és a különböző jogszabályok összehangolása, az ellentmondások feloldása érdekében;

6.2. „gyermek-szülö-kutya” hármasának jogi tisztázása (kiskorú gyermek esetén a segítőkutya-igazolvány csak akkor érvényes, ha jelen van a fogyatékossággal élő gyermek, így például a segítőkutyát kezelő szülő nem tud elmenni ügyet intézni, amíg a gyermeke fejlesztőfoglalkozáson van). 


\section{Segítőkutya-gazdák felkészítése, biztatása}

7.1. a felelős állattartásra és a segítőkutyájuk megfelelő kontrollálására (hogy véletlenül se terjedhessenek el a társadalomban tévhitek a segítőkutyákkal kapcsolatban);

7.2. a konfliktushelyzetek kezelésére (például asszertív, diplomatikus kommunikációs stílus alkalmazása a biztonsági őrök felé, egységes formanyomtatvány készítése segítőkutya-gazdáknak ilyen szituációban használható jegyzőkönyvhöz);

7.3. aktivitásra (a kudarcélmények ellenére), a közlekedés során történő „spontán" szemléletformálásra (minél több fegyelmezett segítőkutyát látnak a kívülálló emberek, várhatóan annál jobban nő társadalmi elfogadottságuk).

\section{Inkluzív szemléletmód elterjesztése}

8.1. érintett személyek bevonása a munkafolyamatokba (például kutyák képzése, egyesületek koordinálása), társadalmi tudatformálás hiteles segítőkutya-gazdákkal;

8.2. fogyatékossággal élő szakemberek és tapasztalati szakértők véleményének kikérése a döntési folyamatokban (például vizsgaszabályzatok kialakítása, segítőkutya-gazdákat érintő jogszabály módosítása során).

A fenti javaslatok megfogalmazásakor törekedtem arra, hogy azok harmóniában álljanak a fogyatékosságügyi ENSZ egyezmény szellemiségével és alapfogalmaival is (például egyetemes tervezés, észszerű alkalmazkodás).

Ahogy a hatásvizsgálatokat összegző folyamatábra is szemlélteti, a cselekvési tervet a segítőkutya-gazdák és a társadalom oldaláról egyaránt szükséges értékelni.

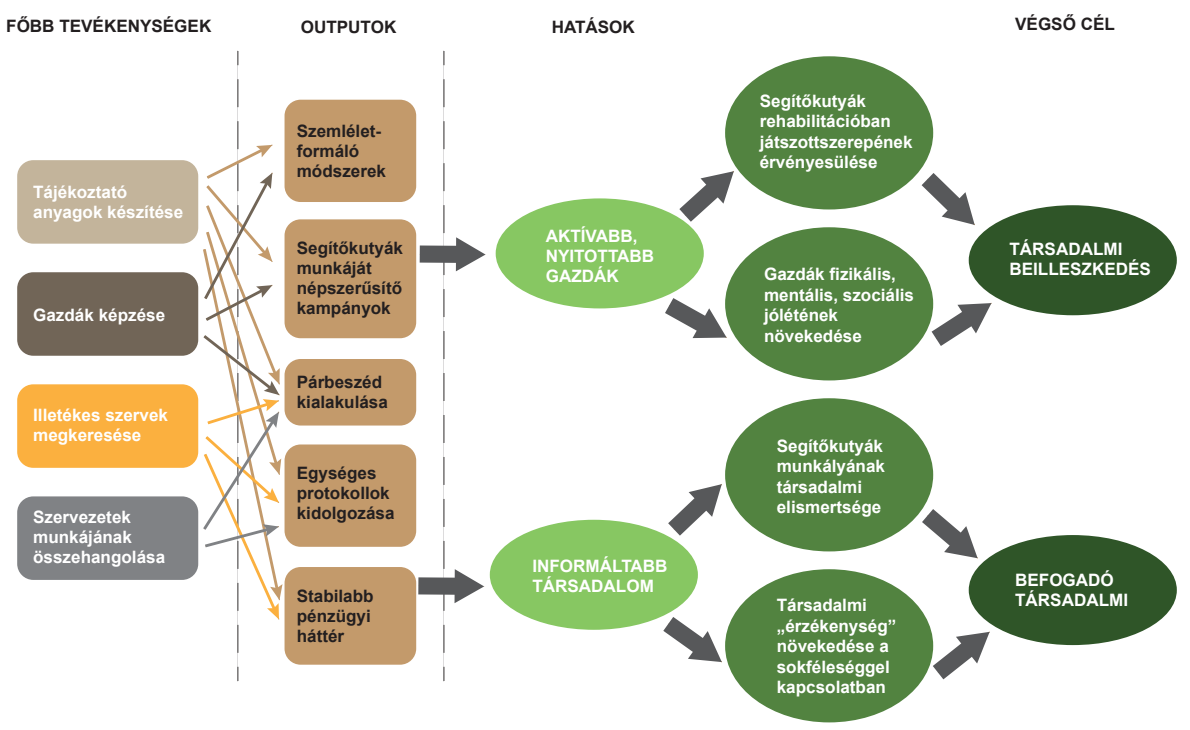

2. ábra. Hatásútvonal-térkép a kutatás eredményei alapján (saját szerkesztés)

A cselekvési tervet és a hatásútvonal-térképet tekintve, három fontos elemet emelek ki, a kutatás tapasztalatai alapján. 
1. Mivel kutatási eredmények alátámasztották, hogy a segítőkutyák elősegítik a gazdájuk rehabilitációját és társadalmi integrációját (Loványi, 2020a), szükség volna arra, hogy stabilabb finanszírozási háttér támogassa a segítőkutyák képzését.

2. A különböző szervek közötti párbeszéd kialakítása elengedhetetlen a segítőkutyák társadalmi elfogadottsága érdekében. A szolgáltatási intézmények sokszor téves információk vagy teljes tájékozatlanság miatt tartanak a segítökutyák beengedésétől. Véleményem szerint a megfelelő kommunikáció hozzájárulhat a segítőkutya-gazdák egyenlő esélyű hozzáféréséhez, a kiképző szervezetek és a gazdák is segíthetnek az irreális félelmek megszüntetésében.

3. Végül, de nem utolsósorban: szükségesnek tartom a különböző szervezetek és érintett, fogyatékos személyek összefogását, együttműködését. Az öszszegyűjtött javaslatokból a NEO Magyar Segítőkutya Közhasznú Egyesületnél számos tevékenységet vittünk már véghez, azonban együtt még hatékonyabbá válhatna mindannyiunk munkája, mert sokfelé kell még eljuttatnunk a segítőkutyák hírét és a tolerancia eszméjét.

Ahogy egy korábbi nemzetközi felmérésböl is kiderült, van, ahol a jogi kodifikáció jóval előrébb jár, mint azok társadalmi betartása - és fordítva (Loványi, 2020a). Talán nem véletlen, hogy - Magyarországhoz hasonlóan - sokszor ott részletezőbb a jogi szabályozottság, ahol a társadalmi elfogadás, hozzáállás még nem teljesen „önszabályozó” módon történik. Vagyis, ha valami nem jól működik e téren, nem feltétlenül a szabályozáshoz kell nyúlni elöször, hanem inkább a szemléletformálásra, a fogyatékossággal és a segítőkutyákkal kapcsolatos információk terjesztésére érdemes összpontosítani. A „Semmit rólunk nélkülünk!” elvvel és a fogyatékosságügyi ENSZ egyezménnyel azonosulva, mely kimondja, hogy a fogyatékos embereket be kell vonni a legmagasabb szinteken a döntési folyamatokba, véleményem szerint mi, érintett gazdák is tudunk tenni az esélyegyenlőség előmozdítása érdekében. Nem célravezető csak a társadalomtól várnunk a megoldást. Ha mi is nyitottak vagyunk, akkor nagyobb az esély, hogy a környezet is értékként fog tekinteni a sokféleségre, és a segítőkutyák munkája még jobban bekerül a köztudatba.

A tanulmány lezárásaképpen megosztom az egyik interjúalanyom tanácsát, amiben arra buzdít minket, hogy a kudarcok ellenére ne adjuk fel és maradjunk aktívak.

„Precedensekkel kellene utat törni, és talán a másik oldalon is bátrabban vinni mindenhova a segítökutyákat, mert biztos nem könnyü, a kutya gazdája is tartózkodhat az ilyen helyzetektöl, de lehet, hogy egy csomó pozitív élménye születhetne neki, meg a környezetnek is."

\section{Irodalom}

1998. évi XXVI. törvény a fogyatékos személyek jogairól és esélyegyenlőségük biztosításáról 27/2009. (XII. 3.) SZMM rendelet a segítő kutya kiképzésének, vizsgáztatásának és alkalmazhatóságának szabályairól

2007. évi XCII. törvény a Fogyatékossággal élő személyek jogairól szóló egyezmény és az ahhoz kapcsolódó Fakultatív Jegyzőkönyv kihirdetéséről 
Az alapvető jogok biztosának jelentése az AJB 2663/2013. számú ügyben. https://www.ajbh.hu/ documents/10180/1117870/Jelentés+a+segítő+kutyák+alkalmazásáról+2663_2013/8e7ca2ba-a8f4-44a2-b0e8-a7673cd18404?version=1.0 Letöltés ideje: 2021.01.15.

Az alapvető jogok biztosának jelentése az AJB 735/2017. számú ügyben. https://www.ajbh.hu/ documents/10180/2602747/Jelentés+a+segítő+kutyák+használóinak+jogairól+735_20 17/31579162-c2c8-4eaa-b24f-a7b667b5581e?version=1.0\&inheritRedirect=true Letöltés ideje: 2021.01.15.

Az Egyenlő Bánásmód Hatóság EBH/38/2018. számú ügye. https://www.egyenlobanasmod.hu/ hu/jogeset/ebh382018 Letöltés ideje: 2021.01.15.

Babbie, E. (2008). A társadalomtudományi kutatás gyakorlata. Balassi Kiadó, Budapest.

Bergold, J. \& Thomas, S. (2010). Partizipative Forschung. In Mey, G. \& Mruck, K. (eds.), Handbuch Qualitative Forschung in der Psychologie. VS Verlag, Wiesbaden. 333-344. https://doi.org/10.1007/978-3-531-92052-8_23

Eddy, J., Hart, L. A. \& Boltz, R. P. (1988). The effects of service dogs on social acknowledgements of people in wheelchairs. Journal of Psychology, 122.1:39-45. https://doi.org/10. 1080/00223980.1988.10542941

ELTE Bárczi Gusztáv Gyógypedagógiai KarTudományos és KutatásetikaiBizottság(ELTEBGGYK TUKEB) kutatásetikai elvei (2020). https://barczi.elte.hu/media/6e/43/0e66bccbb5bf35a07fcdaa80c78764a25ab5d7e7e24a8172268f2cc8c43b/ELTE_BGGYK_Kutatasetikai_elvek_hatalyos_20200213.pdf Letöltés ideje: 2021.01.15.

Hoffman, M. (2013). Lend me an ear: Temperament, selection and training of the hearing ear dog. Dogwise Publishing, Washington.

Horváth P. L. (2017). Adalékok a könnyen érthető kommunikáció nemzetközi történetéhez. Gyógypedagógiai Szemle, 45.3:159-174.

Juhász V. (2009). A MaxQDA szövegelemző program. In Nádor Orsolya (szerk.), A magyar mint európai és világnyelv: A XVIII. Magyar Alkalmazott Nyelvészeti Kongresszus előadásai. Balassi Intézet, Budapest. n.a.

Katona V., Cserti-Szauer Cs. \& Sándor A. (szerk.) (2019). Együtt oktatunk és kutatunk! Inkluzív megközelítés a felsőoktatásban. ELTE Bárczi Gusztáv Gyógypedagógiai Kar, Budapest.

Lane, G.F., Matthews, B.E., Ellison, C.J. \& Palmer, C.D. (2016). There's more to a dog guide than meets the eye: A preliminary exploration of potential health benefits of dog guide use. International Journal of Orientation and Mobility, 8.1:27-36. https://doi.org/10.21307/ ijom-2017-065

Loványi E. (2015). Kuku és barátai - Ismerjük meg közösen a segítőkutyák világát! NEO Magyar Segítőkutya Egyesület, Budapest.

Loványi E. (2018a). Híd a csend és a hangok világa között? Szemléletformálás segítőkutyákkal a hallássérült személyek társadalmi beilleszkedése érdekében. Fogyatékosság és társadalom, 4.2:31-47. https://doi.org/10.31287/FT.hu.2018.2.3

Loványi E. (2018b). A segítőkutyák hatása gazdáik társadalmi integrációjára - egy inkluzív kutatás bemutatása. In Fehérvári A., Széll K. \& Misley H. (szerk.), Kutatási sokszinűség, oktatási gyakorlat és együttmüködések: Absztraktkötet. ELTE Pedagógiai és Pszichológiai Kar, Budapest. (235.)

Loványi E. (2019). Egyenlő esélyű hozzáférés segítőkutyával? - egy doktori kutatás eredményei. Előadás, „Segítőkutyákkal az integrációért III.” című konferencia. ELTE Bárczi Gusztáv Gyógypedagógiai Kar, Budapest.

Loványi E. (2020a). A segítőkutyák szerepe a társadalmi integrációban - egy emancipatív kutatás eredményei. (Doktori értekezés.) ELTE Pedagógiai és Pszichológiai Kar Neveléstudományi Doktori Iskola, Budapest.

Loványi E. (2020b). Amikor maguk az érintettek a kutatók: Az emancipatív kutatások jelentősége. In Bihari, Molnár, \& Szikszai-Németh (szerk.), Tavaszi Szél - Spring Wind 2019. Tanulmánykötet, III. kötet. Doktoranduszok Országos Szövetsége, Budapest. 384-396.

Loványi E., \& Perlusz A. (2016). Raising Awareness of Society Using Service Dogs in the Integration of Hearing Impaired Children into Preschool and Elementary School Communities. In Karlovitz, T., J. (ed.), Studies from Education and Society International Research Institute sro., Komarno. 13-25.

Magyar Jelnyelvi Tolmácsok Etikai Kódexe (2014). http://josz-elnokseg.blogspot.hu/2014/09/ a-magyar-jelnyelvi-tolmacsok-etikai.html Letöltés ideje: 2021.01.15.

Martinez, R. \& Barns S. M. (2013). Training Your Diabetic Alert Dog. Rita Martinez and Susan M. Barns, Middletown.

Marton K. (2014). Participation of children and adults with disability in participatory and emancipatory research. Neveléstudomány 2.3. 23-32. 
Mercer, G. (2002). Emancipatory Disability Research. In Barnes, C., Oliver, M. \& Barton, L. (ed.), Disability Studies Today. Polity Press, Cambridge. 228-249.

NEO Magyar Segítőkutya Közhasznú Egyesület (NEO MSKKE) honlapja (2021). https://segitokutya.net/ Letöltés ideje: 2021.01.15.

Rintala, D. H., Matamoros, R. \& Seitz, L. L. (2008). Effects of assistance dogs on persons with mobility or hearing impairments: A pilot study. The Journal of Rehabilitation Research and Development, 45.4:489-503. https://doi.org/10.1682/JRRD.2007.06.0094

Sanders, C. R. (2000). The impact of guide dogs on the identity of people with visual impairments. Anthrozoos, 13.3:131-139.

https://doi.org/10.2752/089279300786999815

Sántha K. (2013). Multikódolt adatok kvalitatív elemzése. Eötvös József Könyvkiadó, Budapest.

Sántha K. (2017). Számítógéppel támogatott kvalitatív adatelemzés a hazai neveléstudományi PhD-képzésben. Képzés és gyakorlat, 15.1-2:159-173. o. https://doi.org/10.17165/ TP.2017.1-2.9

Seidman, I. (2002). Az interjú mint kvalitatív kutatási módszer. Műszaki Könyvkiadó, Budapest. Szokolszky Á. (2004). Kutatómunka a pszichológiában. Osiris Kiadó, Budapest.

Viau, R., Arsenault-Lapierre, G., Fecteau, S., Champagne, N., Walker, CD., \& Lupien, S. (2010). Effect of service dogs on salivary cortisol secretion in autistic children. Psychoneuroendocrinology, 35.8:1187-1193.

https://doi.org/10.1016/j.psyneuen.2010.02.004

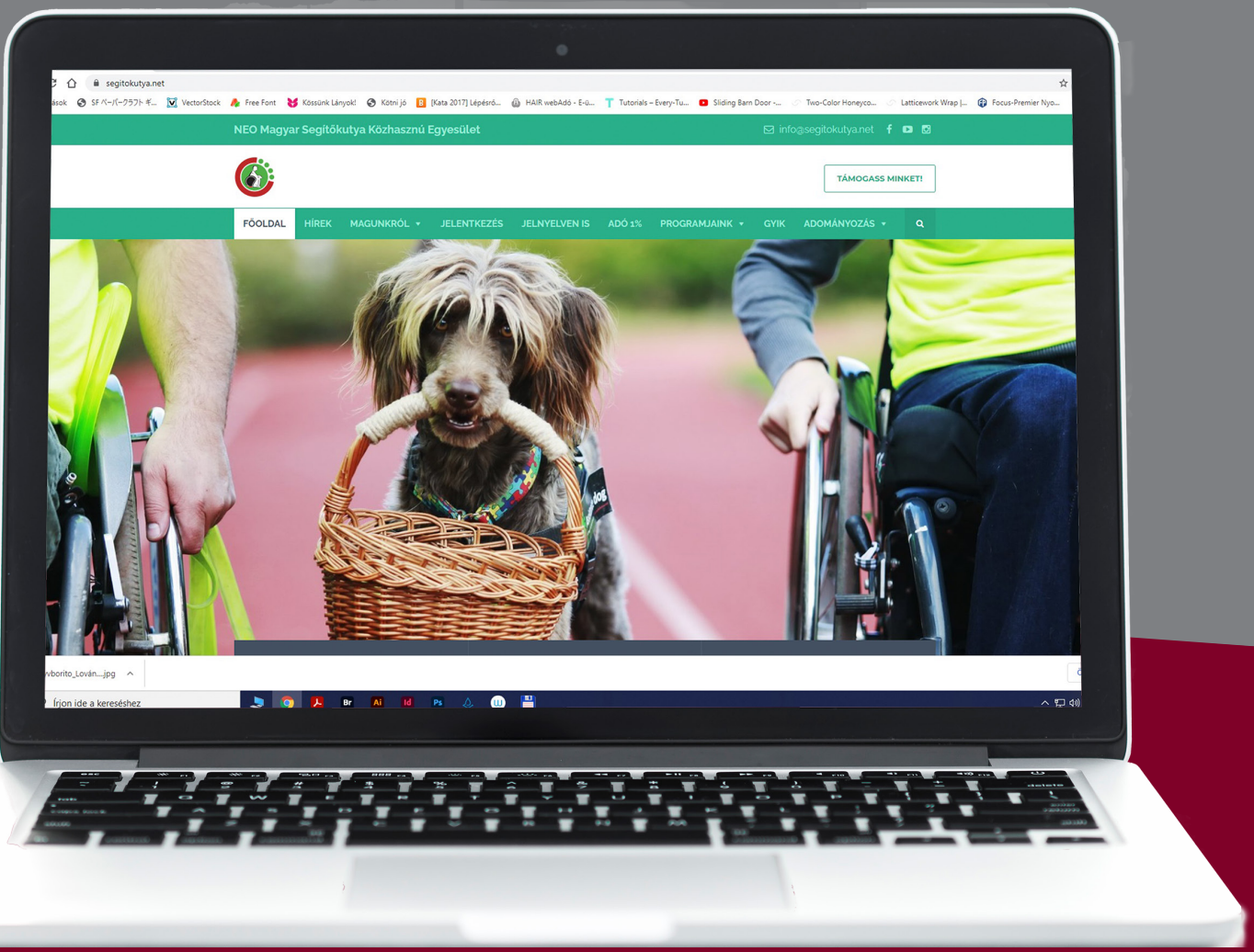




\section{BEMUTATKOZÁSOK}

Berényi Zoltánné: gyógypedagógus. Gyakorlati tapasztalatokkal a tanulásban akadályozott tanulók integrált nevelése-oktatása terén rendelkezik. Gyógypedagógiai tanári diplomáját az ELTE Bárczi Gusztáv Gyógypedagógiai Karán szerezte 2006ban, tanulásban akadályozottak pedagógiája szakon. Gyógypedagógus szakvizsgát tett 2019-ben. Jelenleg a bucsai II. Rákóczi Ferenc Általános Iskola és Alapfokú Múvészeti Iskolában gyógypedagógus. Fő érdeklődési területe a könnyen érthető kommunikáció gyakorlati alkalmazása az általános iskolában, valamint könnyen érthető oktatási segédanyagok készítése.

Borosné Rimaszombati Dóra: gyógypedagógus. 2011-ben szerezte meg értelmileg akadályozottak pedagógiája és tanulásban akadályozottak pedagógiája szakos gyógypedagógus diplomáját az SZTE Juhász Gyula Pedagógusképző Karán, majd 2014-ben szomatopedagógus végzettséget szerzett, 2018-ban pedig gyógypedagógus szakvizsgát tett az ELTE Bárczi Gusztáv Gyógypedagógiai Karán. Jelenleg ugyanitt a gyógypedagógia-tanár mesterképzés hallgatója.

Cziráki Zsolt: önérvényesítő. Az ásotthalmi Csongrád-Csanád Megyei Napsugár Otthon Rehabilitációs Célú Lakóotthona lakója. Védett munkahelyen dolgozik bedolgozóként. Tagja az Értelmi Fogyatékosok Csongrád Megyei Egyesületének, ahol aktív önérvényesítő. Az SZTE Juhász Gyula Pedagógusképző Kar gyógypedagógus-képző Intézetében participatív oktatóként vesz részt a könnyen érthető kommunikáció oktatásában. A Magyar Speciális Mozgókép Egyesülettől 2018-ban különdíjat nyert „Az aktuális téma feldolgozásért” „Jövőképek” c. filmjével, 2019-ben ugyancsak különdíjat kapott a kiváltás szemléletének bemutatásáról szóló „Hazaérkeztem" c. filmmel.

Galai Bianka: gyógypedagógus. 2020-ban szerzett diplomát az SZTE Juhász Gyula Pedagógusképző Karán értelmileg akadályozottak pedagógiája és tanulásban akadályozottak pedagógiája szakirányon. Jelenleg a Csongrád Megyei Pedagógiai Szakszolgálat Kisteleki Tagintézményének gyógypedagógusa.

Hegedűs Hanga: egyetemi hallgató. Az SZTE Juhász Gyula Pedagógusképző Kar Gyógypedagógus-képző Intézetében nappali tagozatos, végzős hallgató értelmileg akadályozottak pedagógiája és logopédia szakirányokon, gyógypedagógia alapszakon. Az Új Nemzeti Kiválóság Program (ÚNKP) keretében a 2019/20. és a 2020/21. tanévben kutatási ösztöndíjat nyert. A 2019. évi OTDK-n a Pedagógiai, Pszichológiai, Andragógiai és Könyvtártudományi Szekció, Gyógypedagógia elméleti és gyakorlati témakörei Tagozaton második helyezést ért el „A kevesebb néha több” címü tanulmányával. Fő érdeklődési területe: az értelmileg akadályozott személyek nyelvi képességeinek mérése és fejlesztése. 
Horváth Péter László: adjunktus. Az SZTE Juhász Gyula Pedagógusképző Kar Gyógypedagógus-képző Intézet munkatársa. Oligofrénpedagógia - szurdopedagógia szakos gyógypedagógiai tanár (1993, Bárczi Gusztáv Gyógypedagógiai Tanárképző Főiskola), speciális pedagógia szakos tanár és szakpedagógus (1996, ELTE Bölcsészettudományi Kar). Doktori fokozatát 2020-ban szerezte az egri Eszterházy Károly Egyetem Neveléstudományi Doktori Iskolájában. Fő kutatási területe a könynyen érthető kommunikáció értelmi sérült személyekkel, illetve a különleges szükségletű gyermekek örökbeadása és örökbefogadása, a felnőtt értelmi sérült személyek önrendelkezése.

Keszey Borbála: konduktor, okleveles gyógypedagógus. Jelenleg a Nemzeti Fogyatékosságügyi és Szociálpolitikai Központ kommunikációjukban akadályozottak munkacsoportjának tagja.

Ladányi Lili: tanársegéd. Az SZTE Juhász Gyula Pedagógusképző Kar Gyógypedagógus-képző Intézetének munkatársa, az Erzsébet a Kárpát-medencei Gyermekekért Alapítvány szakértő munkatársa. Alapdiplomáját 2008-ban szerezte az SZTE-n tanulásban akadályozottak pedagógiája szakos tanár és pedagógia szakos nevelőként. Az ELTE Bárczi Gusztáv Gyógypedagógiai Karán 2010-ben végzett autizmus spektrum zavarok pedagógiája szakos tanárként, 2014-ben gyógypedagógus szakvizsgát tett, majd 2019-ben fejezte be a mesterképzést okleveles gyógypedagógia-tanárként. Jelenleg az Eszterházy Károly Egyetem Neveléstudományi Doktori Iskola doktorandusz hallgatója.

Loványi Eszter: gyógypedagógus, szociológus. Az ELTE Bárczi Gusztáv Gyógypedagógiai Kar adjunktusa, súlyos hallássérüléssel született. Mindennapjait hangjelző kutya könnyíti meg. Szabadidejében önkéntesként, programvezetöként segíti a NEO Magyar Segítőkutya Közhasznú Egyesület munkáját. 2020-ban szerzett doktori fokozatot, disszertációját a segítőkutyák szerepe a társadalmi integrációban témakörben készítette.

Magyar Adél: gyógypedagógus, esélyegyenlőségi szakoktató, képzésben lévő családterapeuta, neveléstudományból PhD-fokozattal rendelkezik. A SZTE Juhász Gyula Pedagógusképző Kar Gyógypedagógus-képző Intézet főiskolai docense, a szegedi Odú Központ, Pedagógiai Szakszolgálati Intézményt fenntartó KORINTA Alapítvány vezetője. Kutatási területe az értelmi fogyatékosságról alkotott társadalmi kép változásai, családközpontú koragyermekkori intervenció.

Menich Nóra: szociálpolitikus, kutató. Doktorjelölt az ELTE Társadalomtudományi Kar Szociológia Doktori Iskolában. Kutatási témája az önálló életvitelt támogató-segítő eszközök és technológia hozzáférhetősége Magyarországon és Európában.

Német Beáta: gyógypedagógus. Az SZTE Juhász Gyula Pedagógusképző Karán szerzett diplomát 2020-ban értelmileg akadályozottak pedagógiája és tanulásban akadályozottak pedagógiája szakirányon. Jelenleg a hódmezővásárhelyi Kozmutza Flóra Óvoda, Általános Iskola, Szakiskola, Kollégium, EGYMI 7. osztályának osztályfönöke. 
Peszeki Dorina: Az SZTE Juhász Gyula Pedagógusképző Kar Gyógypedagógus-képző Intézet nappali tagozatos, harmadéves hallgatója. Tanulmányait értelmileg akadályozottak és tanulásban akadályozottak pedagógiája szakirányon végzi. Az Új Nemzeti Kiválóság Program (ÚNKP) keretében a 2020/21. tanévben kutatási ösztöndijat nyert. Ugyanebben a tanévben az OTDK keretében a helyi fordulóban harmadik helyezést ért el, és így bejutott az országos fordulóra „A gondnokságról alkotott vélemény: előny vagy hátrány?" című tanulmányával. Érdeklődési területei a gondnokság intézményrendszere, a könnyen érthető kommunikáció, valamint az autizmus spektrumzavarban érintett tanulók támogatása.

Porkoláb Mihály: projektmenedzser. Az SZTE Juhász Gyula Pedagógusképző Kar Gyógypedagógus-képző Intézet munkatársa, a Mentor(h)áló Pedagógiai Szolgáltató Központ vezetője.

Pukánszky Béla: egyetemi tanár (SZTE JGYPK, EKE, Selye János Egyetem, Komarno). Zenetanár alapvégzettség után pedagógia szakos diplomát szerzett a budapesti Eötvös Loránd Tudományegyetemen, 1980-ban. Egyetemi doktori címet 1983-ban, kandidátusi fokozatot 1989-ben kapott. A Debreceni Egyetemen habilitált 2000-ben, a Magyar Tudományos Akadémia doktora pedig 2004-ben lett. Az SZTE, illetve annak jogelődjein 1985 óta oktató. Egyetemi tanárrá 2005-ben nevezték ki. 2008 és 2019 között a Gyógypedagógus-képző Intézetet vezette. 1990 óta tagja (2014 és 2021 között vezetője) a Magyar Tudományos Akadémia Pedagógiai Tudományos Bizottságának. A MAB szakértője, 2006 és 2009 között elnökként vezette a Tanárképzési Bizottság munkáját. Fő kutatási területe a pedagógiatörténet. Publikációiban foglalkozik a gyermekkor és a nőnevelés történetével, a 19-20. századi iskolatörténettel, a pedagógia eszmetörténetével és a gyógypedagógia történetével. Témavezető és oktató az ELTE és a PTE neveléstudományi doktori iskolájában. 2016 óta Eszterházy Károly Egyetem neveléstudományi doktori iskoláját vezeti.

Radics Márta: gyógypedagógus. Az SZTE Juhász Gyula Pedagógusképző Kar Gyógypedagógus-képző Intézet munkatársa 2012 óta, a Csongrád-Csanád Megyei Pedagógiai Szakszolgálat Megyei Szakértői Bizottság logopédusa 2017 óta. Logopédia szakos tanár és tanulásban akadályozottak szakos terapeuta (2005, ELTE BGGYFK), okleves nyelv- és beszédfejlesztő tanár (2020, SZTE JGYPK), szakvizsgázott pedagógus mentorpedagógus szakterületen (2020, SZTE KÖVI). Kutatási területei a nyelvi fejlesztés és a játékok szerepe a pedagógiai tevékenységekben.

Sallai Ilona: önérvényesítő. 2016 óta az ÉFOÉSZ érdekvédelmi tanácsadója. Az ÉFOÉSZ Központban, Budapesten működő Önérvényesítő Csoport segítője, amelyen belül társainak segít jogaik megismerésében és a jogaikért történő felszólalásban. Az önérvényesítők Együtt Velünk nevű, könnyen érthető honlapjának egyik szerkesztője. Az ELTE Bárczi Gusztáv Gyógypedagógiai Karon és az SZTE Juhász Gyula Pedagógusképző Karon participatív oktatóként vesz részt a könnyen érthető kommunikáció oktatásában. Tapasztalatairól a németországi hildesheimi egyetemen tartott előadást 2020 februárjában. 
Szarapka Dóra: A szabadkai „Žarko Zrenjanin“ Általános és Középiskola munkatársa, az 5/2 osztály gyermekeinek büszke osztályfőnöke. Munkatársa a szabadkai székhelyű Magyar Házban működő Pannon RTV-nek is, ahol a könnyen érthető hírek szerkesztéséért felel. Okleveles tanítói diplomáját 2016-ban szerezte Szabadkán, a Magyar Tannyelvű Tanítóképző Karon. Ugyanitt a tanítói mesterképzés oklevelét is megszerezte 2017-ben. Rendelkezik inkluzív fejlesztő szakpedagógusi diplomával, amit az SZTE Juhász Gyula Pedagógusképző Kar Gyógypedagógus-képző Intézet kihelyezett tagozatán, Szabadkán szerzett 2019-ben. Jelenleg másodéves, levelező tagozatos hallgató gyógypedagógia alapszakon, értelmi akadályozottak pedagógiája és tanulásban akadályozottak pedagógiája szakirányon az SZTE Juhász Gyula Pedagógusképző Kar Gyógypedagógus-képző Intézetében. Szívügyének tartja a vajdasági magyar fogyatékosként azonosított emberek támogatását és a mentális akadálymentesítés kialakítását. Magát a könnyen érthető hírek szerelmesének vallja.

Vecseri Zita: gyógypedagógus. Az SZTE Juhász Gyula Pedagógusképző Karán szerzett diplomát 2020-ban értelmileg akadályozottak pedagógiája és tanulásban akadályozottak pedagógiája szakirányon. Jelenleg a köznevelés területén, a Csongrád-Csanád Megyei Pedagógiai Szakszolgálat Csongrádi Tagintézményében, óvodás gyermekek és általános iskolás tanulók képességfejlesztését végzi.

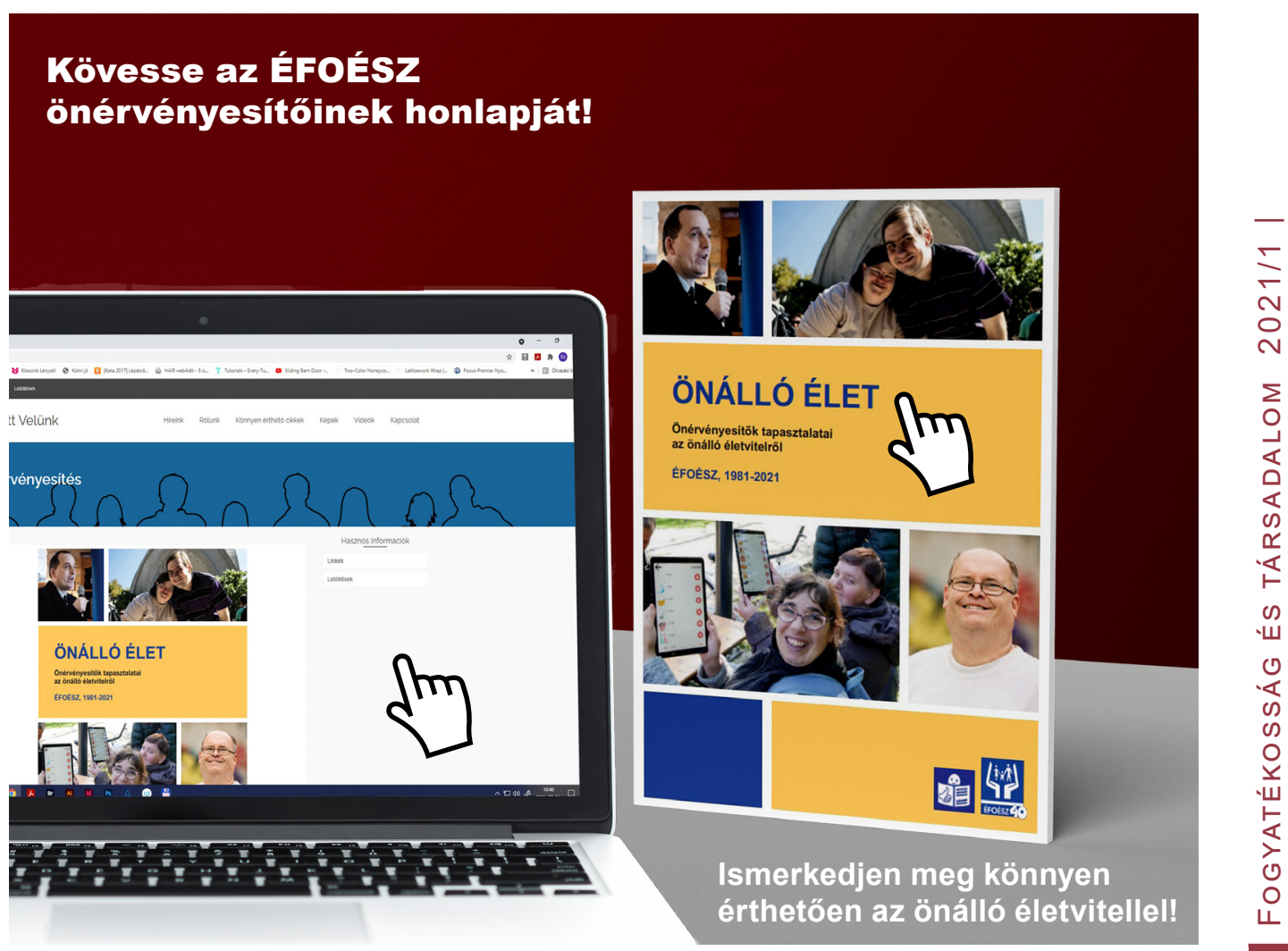




\section{KöNNYEN ÉRTHETö INFORMÁcIós KöZPONT}

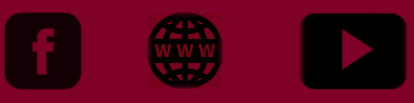

\section{Katona Vanda - Cserti-Szauer Csilla - Sándor Anikó Együtt oktatunk és kutatunk!}

Amint e rendhagyó kötetböl hamarosan kibomlik Olvasóink előtt, a szerzők által elméletben és gyakorlatban müvelt terület két fundamentális eleme: az emberi méltóság és a helyes határoltság kérdése. A participatív (egyetemi) oktatás ma, a 21. század második dekádjának végén, külföldön és hazánkban is unikális kezdeményezés. Legegyszerübben fogalmazva annyit tesz, hogy közösen oktatnak professzionális, többnyire doktori fokozattal rendelkező tanárok és azzal nem feltétlenül bíró, ám fogyatékossággal élő személyek.

Aki tanított, vagy akit tanítottak már iskolarendszerü képzésben, tisztában van vele, hogy a tanári tér - hatalmi tér. Az oktatás, különösképpen a frontálisan és hierarchikusan müködtetett, tekintélyelvü és alkalmanként elnyomó, monolit formát öltött oktatás hatalmi terében, ahol a tanár áll a középpontban, sok tekintetben ő gyakorolja a hatalmat. Ezzel a logikával megy szembe számos olyan demokratikus és nemritkán projektközpontú oktatási módszer, amelyet külföldön és Magyarországon egyaránt alkalmaznak. Mi a Bárczin átvettük és alkalmazzuk őket. Olyanok is szép számmal vannak, amelyeket mi fejlesztettünk ki és alkalmazunk is. Ezek a módszerek progressziv környezetként hozzásegítenek egy olyan emberi és oktatási környezet megalkotásához, amely támogatja az oktatás terének demokratizálását.

Kötetünk két fontos üzenetet hordoz. Az egyik az emberi méltóság fogalmának fogyatékosságtudományi területen megvalósított újraértelmezése. A másik pedig annak a kérdése, ahogyan azt egyik mesterünktöl, Gilles Deleuzetöl megtanultuk: hogy mivé válunk mi együtt mindeközben. 